\title{
THE GOTHIC AS A PRACTICE: Gothic Studies, Genre and the Twentieth Century Gothic
}

\author{
by \\ Timothy Graham Stanford Jones
}

\begin{abstract}
A thesis
submitted to the Victoria University of Wellington in fulfilment of the requirements for the degree of Doctor of Philosophy in English
\end{abstract}

Victoria University of Wellington 


\begin{abstract}
Gothic studies, the specialist academic field that explores the Gothic text, has developed substantially over the last twenty-five years. The field often frames the Gothic as a serious literature, involved in historic discourse, and having special psychological acuity; this thesis suggests that there are a number of problems with these argumentative strategies, and that the academy now makes claims for the Gothic that are discontinuous with how this popular genre is understood by most readers.

While Gothic studies is the study of a genre, curiously, it has seldom engaged with theorisations of genre. Nevertheless, an understanding of what genre is, and how it alters reading practice, is crucial to understanding the Gothic text. This thesis attempts to reconcile and develop a number of disparate approaches to genre through Pierre Bourdieu's notion of habitus. It argues that genre is not a set of textual conventions but a group of procedures that facilitate and modify both writing and reading practices. Consequently, genres like the Gothic should be seen as discrete historicised phenomena, which retain a cohesive practical sense of how they ought to be performed before they hold discursive properties. Rather than arguing for the literary value of the Gothic, this thesis understands the genre as a popular practice. The consequences of this theorisation of the Gothic are explored in case studies of particular moments in three separate Gothic fields.
\end{abstract}

Firstly, the American Gothic of the mid-nineteen-eighties, particularly Stephen King's It, Joyce Carol Oates' Mysteries of Winterthurn, and Toni Morrison's Beloved, facilitates a discussion of the relationship between Gothic and literary practices. The Gothic text has its origins in 'lowbrow' popular culture, even as it sometimes aspires to 'highbrow' literary performances.

Secondly, the English Gothic of the nineteen-sixties is used to stage a discussion of both the way that readers become involved and immersed in the Gothic text, creating a distinct subjunctive 'world', and of the way that Gothics define themselves in relation to each other. The discussion refers to Dennis Wheatley's The Devil Rides Out, which heavily influenced the field, as demonstrated in works by Susan Howatch, Kingsley Amis, Robert Aickman and Mervyn Peake. Wheatley's depiction of the black mass became a key Gothic procedure, and can be read as this particular field's metaphor of its own practice. 
Thirdly, New Zealand's underdeveloped Gothic field provides a venue to explore the Gothic's relationship with nation and national literature, and how the practice is involved in landscape. Frank Sargeson's stories and his novella The Hangover, together with Janet Frame's A State of Siege are texts authored by canonical New Zealand writers that participate in a local Gothic, although their participation in popular genre has been little recognised.

This thesis argues that the Gothic is a commonsense cultural practice, facilitated through the canniness of habitus. 


\section{ACKNOWLEDGEMENTS}

I am grateful to Victoria University of Wellington for granting me the scholarship that has enabled my research. I am also grateful to the Faculty Research Committee for their support, which allowed me to travel to the International Gothic Association conferences in 2007 and again in 2009. Thanks are also due to Education New Zealand's Postgraduate Study Abroad Award programme that assisted my travel in 2009.

Thank you to Jerrold E. Hogle, Andrew Smith, and to the editors of The Irish Journal of Gothic and Horror Studies for their support and interest.

I have very much appreciated the kindness and interest of the English faculty at Victoria, all of whom have been generous enough to express their interest in my progress and my project. Special thanks to David Norton, Jane Stafford, Mark Williams, Harry Ricketts, Heidi Thomson, Peter Whiteford and Tatjana Schaefer, for looking out for me.

I am extraordinarily thankful for the input of my supervisors, Anna Jackson and Charles Ferrall. They have been as astute as they have been supportive and I have felt very lucky to have them.

And finally, an enormous thank you to my wife, Jane, whose support and belief has never once flagged over the course of these years, despite the nearGormenghastian scope of the obsession my research has entailed. 


\section{CONTENTS}

1. Some Problems in Gothic Studies, and a Theory of the Gothic

2. Discourse and Practice in the American Gothic of the Nineteen-Eighties 56

American Gothic Studies and the Field 60

$\begin{array}{ll}\text { It } & 73\end{array}$

Mysteries of Winterthurn $\quad 88$

Beloved 109

Conclusion: Headless Bride $\quad 124$

3. Ritual and Subjunctivity in the English Gothic of the Nineteen-Sixties $\quad 128$

The Devil Rides Out 132

The Devil on Lammas Night $\quad 145$

The Green Man 153

Two Tales from Dark Entries $\quad 160$

The Gormenghast Trilogy 174

Conclusion: The Highgate Vampire 189

4. Towards a New Zealand Gothic: Practice in an

Underdeveloped Field 196

Some Problems in Critical Versions of New Zealand

Literature and the New Zealand Gothic 201

Frank Sargeson's Gothic 212

Janet Frame's Reception and A State of Siege 235

Conclusion: Gothic Landscapes and Antipodean Tales 249

Conclusion: The Gothic as Practice 257

$\begin{array}{ll}\text { Works Cited } & 261\end{array}$ 


\section{Chapter One:}

\section{Some Problems in Gothic StUdies, AND A Theory OF THE Gothic}

What is the Gothic? Appropriately for a genre that so often revels in ambiguity, even the word has always held an approximate, mutable, contested meaning. This chapter attempts to answer that question, providing a critique of the specialised critical approaches to the genre that have developed over the last thirty-five years, and offering a theoretical response to them. The following chapters explore the genre in the context of the United Kingdom in the nineteen-sixties, the United States in the mid nineteen-eighties, and finally, in New Zealand in the nineteen-thirties through until the nineteen-nineties. Each of these historical 'moments' provides a venue to examine the genre's performativity, its relationship to criticism, literature and national identity, all of which are issues raised as consequences of the theorisation of the genre suggested in this chapter. The argument of this chapter and the case studies that follow hope to address the concerns about Gothic studies raised by Chris Baldick and Robert Mighall, that it often abandons genuine historicity and that

the assumption of Gothic Criticism [is] that the 'Gothic' is to be defined not according to observable features of theme and setting but according to the realms of psychological depth from which it is supposed to originate (dream, fantasy) or the psychological responses it is believed to provoke (fear, terror, horror). Gothic Criticism is frequently unable and unwilling to distinguish its supposed object from the generality of fearful or horrible narratives. ${ }^{1}$

Gothic studies has been reluctant to define the object of its investigation. It is emblematic of this problem that the Oxford English Dictionary has only very recently, in March 2008, introduced a draft addition describing the sense of the word 'Gothic' in which it is critically used, denoting a genre of fiction, not limited by historical

\footnotetext{
${ }^{1}$ Chris Baldick and Robert Mighall, "Gothic Criticism," A Companion to the Gothic, ed. David Punter, Blackwell Companions to Literature and Culture (Oxford: Blackwell, 2000) 216.
} 
origin, that involves the suspenseful, the sensational, the supernatural or macabre. In a sense that exceeds that given by the $O E D$ addition, it could mean a cultural production in one of a number of different media that involves these qualities. This is the primary sense in which this thesis uses the word, encompassing genre labels such as horror, weird stories, dark fantasy, and the literature of the macabre.

The word is expansive, and the $O E D$ includes earlier relevant senses that do not entirely separate themselves as unique. It notes Walpole's use of the word as subtitle to The Castle of Otranto, but this is rightly ascribed to his medievalism rather than to the supernatural and sinister inclinations that might encourage us to label a text as Gothic in a twenty-first century context. However, it is easy to see how, in our present use of the term which does not distinguish between Walpole's wilful anachronism and his brightly haunted imagination, these two separate senses collapse into one another.

That the meanings attached to the word are changeable is hardly a new observation; Alfred E. Longueil noted in 1923 that 'Critical terms, like other speculations, have their ups and downs. So it has been with the adjective "gothic". 2 In a literary context, the term denoted barbarism and a lack of decorum in the early eighteenth century; however, Longueil attributes what he calls the 're-neutralizing' of the word to Bishop Richard Hurd in his 1762 Letters on Chivalry and Romance, where he argued for the value of the 'Gothic romance'. ${ }^{3}$ When Walpole and Reeve used the term, it was already in a recuperated sense; as we will see, Gothic studies has emphasised the need for the recovery of the term.

As more Gothic texts were written and consumed, the present meaning of the word began to emerge, denoting the supernaturalism, orientalism, morbidity and spectral obsessions present within the texts. Longueil believes that this sense had displaced earlier meanings to a significant degree by the end of the eighteenth century. ${ }^{4}$ Michael Gamer suggests that it is not until the early nineteenth century that 'Gothic' denoted a genre; thus the sense of the term discussed here was not really

\footnotetext{
${ }^{2}$ Alfred E. Longueil, "The Word 'Gothic' in Eighteenth Century Criticism," Modern Language Notes 38.8 (1923): 453.

${ }^{3}$ Longueil 456.

${ }^{4}$ Longueil 458-60.
} 
present when what we think of as the 'original' eighteenth century Gothic was forming. ${ }^{5}$ Longueil notes an instance of the phrase 'Gothic imagination' used in 1804 to describe a wild or ghostly imagination, a usage not dissimilar to how we might talk about the Gothic today. ${ }^{6}$ In this construction, the Gothic escapes the confines of text and describes a quality of vision and thought.

Further complications emerge when we note that Gothic and Romantic have been closely related. Wordsworth famously railed against frantic novels and sickly and stupid German tragedies in the Preface to Lyrical Ballads (1800), a polemic intended to differentiate its contents from the contemporary vogue for the Gothic; nevertheless, the collection still included the macabre 'The Rime of the Ancient Mariner', and nearly included 'Christabel' as well. ' 'La Belle Dame sans Merci' and 'Isabella, or the Pot of Basil' both embrace the Gothic; Shelley published two Gothic novels while he was at Eton, ${ }^{8}$ and apparently avidly devoured the semi-literary Gothic bluebooks which were popular at the time. ${ }^{9}$ Both Frankenstein and John Polidori's The Vampyre emerged directly from the Romantic field. Byron himself as much as his writing has become the stuff of Gothic stories; hence the Byronic hero.

Associations abound. The $O E D$ reminds us that the word might connote the supposed savagery of vanished Northern European tribes, or the sophisticated fakery of Gothic Revival architecture. These associations are not central to an understanding of the literary Gothic; yet they contribute to our sense of its meanings. There is no shortage of atavistic barbarism in the texts, and the architectural movement exhibits the medievalism that delighted Walpole and his followers. It is no coincidence that buildings in Gothic Revival style might make ideal settings for Gothic narratives;

\footnotetext{
${ }^{5}$ Michael Gamer, Romanticism and the Gothic: Genre, Reception and Canon Formation, Cambridge Studies in Romanticism (Cambridge: Cambridge UP, 2000) 49.

${ }^{6}$ Longueil 459.

${ }^{7}$ Gamer 123-4.

${ }^{8}$ Anne Williams, Art of Darkness: A Poetics of Gothic (Chicago: U of Chicago P, 1995) 3.

${ }^{9}$ Peter Haining, Introduction, The Shilling Shockers: Stories of Terror from the Gothic Bluebooks, ed. Peter Haining (London: Gollancz, 1978) 13.
} 
indeed, Robert Aickman's story, 'My Poor Friend' posits Westminster as haunted by strange, bat-like children. ${ }^{10}$

Another addition to the $O E D$ entry notes gothic subculture, a phenomenon distinct from the literary productions of Walpole, Beckford and Radcliffe, that nevertheless shares a preference for theatricality, bizarrerie and melancholia. Writers like Poppy Z Brite and Caitlín R Kiernan make the connection explicit, locating Gothic tales inside gothic subcultural milieu. ${ }^{11}$

Through these disparate usages, the Gothic gathers a context for itself, a diffuse canon that includes cultural productions exceeding the literary. These associations add to the potential meaning of the term, but complicate it at the same time. The word sometimes makes it seem as if Ruskinian architecture somehow naturally relates to subcultural fashion. For as long as it has been a term that describes a literature, the Gothic has been unstable and has never held the 'critical incisiveness' that some have felt that it ought. ${ }^{12}$ While this 'fuzziness' is perhaps inherent in any theorisation of the Gothic, it has had a substantial, negative impact on recent critical discussions of the genre.

Gothic studies has expanded enormously over the last thirty-odd years. There had been substantial works written about the genre earlier, ${ }^{13}$ but Gothic studies as we have it now developed in the later nineteen-seventies, with works such as Sandra M. Gilbert and Susan Gubar's pioneering 1979 work The Madwoman in the Attic, Eve

\footnotetext{
${ }^{10}$ In Robert Aickman, Powers of Darkness (London: Collins, 1966).

${ }^{11}$ As in Poppy Z. Brite, Lost Souls (London: Penguin, 1994); or Caitlín R. Kiernan, Silk (New York: Roc, 1998).

${ }^{12}$ Robert L. Platzner and Robert D. Hume, "'Gothic Versus Romantic': A Rejoinder," PMLA 86.2
} (1971): 271.

${ }^{13}$ See, for instance: Edith Birkhead, The Tale of Terror: A Study of the Gothic Romance (London: Constable, 1921); Montague Summers, The Gothic Quest: A History of the Gothic Novel (London: Fortune Press, 1938); Devendra P. Varma, The Gothic Flame: Being a History of the Gothic Novel in England: Its Origins, Efflorescence, Disintegration and Residuary Influence (London: Barker, 1957). A useful sketch of some of the earlier criticism can be found in David Punter, The Literature of Terror: A History of Gothic Fictions from 1765 to the Present Day (London: Longman, 1980) 15-18. 
Kosofky Sedgwick's The Coherence of Gothic Conventions (1980) and especially David Punter's The Literature of Terror (1980). ${ }^{14}$ From these beginnings, a significant scholarly industry has developed: each year brings numerous monographs, collections, and journal articles. Courses are taught, conferences are arranged, and the field has developed a distinctive identity. The 2009 International Gothic Association Conference was attended by more than 220 academics, and, as I understand it, many who submitted abstracts were unable to be accommodated with a slot to present their papers. At the same time, the popular appetite for Gothic texts continues, if anything, to grow. By 1997, it was possible for Mark Edmundson to declare, somewhat hyperbolically, that 'Poe is lord (if there is a lord) in contemporary culture'. ${ }^{15}$

In part due to the sheer volume of critical work produced in the last fifteen years, there is no obvious consensus as to how we ought to understand Gothic fictions, although a general sense of the Gothic has nevertheless emerged. Criticism suggests that the Gothic text will typically articulate serious concerns; about the place of women, about our minds and identities, about issues of race, oppression and guilt, all manner of cultural anxieties touching on the limits of our experience. ${ }^{16}$ Very recently, it has been suggested that the genre is not entirely humourless, ${ }^{17}$ but in the vast majority of critical literature, the Gothic is a grave business indeed.

Gothic criticism, at least within its first twenty-five years, promoted the idea that the Gothic was being resuscitated as a legitimate area of study. In the seventies, there was a perception that the Gothic was 'merely a literature of surfaces and sensations', and that any work involving the Gothic of substantial literary worth had somehow transcended the genre. ${ }^{18}$ Punter noted the genre's 'difficulty in establishing

\footnotetext{
${ }^{14}$ The Sedgwick book seems to have been more generally available, and thus influential, after a new edition in 1986.

${ }^{15}$ Mark Edmundson, Nightmare on Main Street: Angels, Sadomasochism and the Culture of the Gothic (Cambridge, MA: Harvard UP, 1997) 155.

${ }^{16}$ See for instance Williams, Art of Darkness; Teresa Goddu, Gothic America: Narrative, History and Nation (New York: Columbia UP, 1997).

${ }^{17}$ Avril Horner and Sue Zlosnik, Gothic and the Comic Turn (New York: Palgrave Macmillan, 2005).

${ }^{18}$ G.R. Thompson, Introduction, "Romanticism and the Gothic Imagination," The Gothic Imagination: Essays in Dark Romanticism, ed. G.R. Thompson (Pullman: Washington State UP, 1974) 1.
} 
respectable credentials'. ${ }^{19}$ Sedgwick hoped that her work would 'make it easier for the reader of "respectable" nineteenth-century novels to write "Gothic" in the margin'. ${ }^{20}$ This sometimes became an allegation of a preference for realist fiction amongst the 'Twentieth-century keepers of the House of Fiction', so that Gothic fictions had become a 'skeleton in the closet' for the academy. ${ }^{21}$ The view that powerful critics have somehow suppressed the Gothic exists in popular studies of the genre too. ${ }^{22}$ However, claims that the genre was marginalised in privileged discursive spaces such as the academy or prestigious criticism may not be entirely true. Tzvetan Todorov and Robert Kiely were publishing on the genre in the early nineteen-seventies, and interest in individual authors involved with the Gothic remained as strong as ever. ${ }^{23}$ Nevertheless, within the nascent field of Gothic studies, the belief that the genre needed recuperation seems to have created a pressure within critical discourse to argue for the conventional 'worth' of the genre. Baldick and Mighall suggest that:

the Gothic literary tradition has attracted to it partisans and champions who have advanced ever bolder claims for its value, attempting to cast upon it the reflected glories of literary romanticism and of the political traditions of the French Revolution... In our view, Gothic Criticism has abandoned any credible historical grasp upon its object, which it has tended to

\footnotetext{
${ }^{19}$ Punter, Literature of Terror 403.

${ }^{20}$ Eve Kosofsky Sedgwick, The Coherence of Gothic Conventions (New York: Methuen, 1986) 4.

${ }^{21}$ Williams, Art of Darkness $1-2$.

${ }^{22}$ David Pirie, A New Heritage of Horror: The English Gothic Cinema (London: I B Tauris, 2009) 913.

${ }^{23}$ Robert Kiely, The Romantic Novel in England (Cambridge, MA: Harvard UP, 1972); Tzvetan Todorov, The Fantastic: A Structural Approach to a Literary Genre, trans. Richard Howard (Cleveland: P of Case Western Reserve U, 1973); or see, for instance the enormous amount of work published on Poe in the seventies, including Daniel Hoffman, Poe Poe Poe Poe Poe Poe Poe (Garden City, NY: Doubleday, 1972), which was nominated for the National Book Award.
} 
reinvent in the image of its own projected intellectual goals of psychological 'depth' and political 'subversion'. ${ }^{24}$

In other words, the Gothic was 'recovered' by attributing values to the texts that emphasise its legitimacy and likeness to provocative, serious canonical literature, in tune with the critical concerns of the time.

The development of the notion of a 'female Gothic' has been instrumental to the development of Gothic studies as a whole. Lauren Fitzgerald argues that the uptake of Gothic texts was an important strategy for feminist critics, and that 'feminist literary criticism also rescued Gothic studies. ${ }^{, 25}$ The coining of the phrase 'female Gothic' has been attributed to Ellen Moers. The term found general scholarly attention with the publication of Literary Women in 1976, although it was in circulation slightly earlier. ${ }^{26}$

The observation that Gothic texts have a special relationship to female writers and readers is not a new one, most famously suggested in Northanger Abbey. ${ }^{27}$ More recent work has highlighted the appetite readers of both sexes had for the original Gothics, being read perhaps as often by men as women. ${ }^{28}$ Nevertheless, the Gothic had its beginnings in popular texts, and popular fiction in particular has tended to enjoy a largely female readership. ${ }^{29}$ While notions of a female Gothic do not hold the critical power they once might have, their associated argumentative strategies continue to exert considerable influence on the field.

Moers' work remains astute and readable. She begins by describing what she means by the term 'female Gothic':

\footnotetext{
${ }^{24}$ Baldick and Mighall 209.

${ }^{25}$ Lauren Fitzgerald, "Female Gothic and the Institutionalization of Gothic Studies," Gothic Studies 6.1 (2004): 9.

${ }^{26}$ Fitzgerald 8.

${ }^{27}$ Jane Austen, Northanger Abbey, Penguin Classics, ed. Marilyn Butler (1818; London: Penguin, 2003) 103-6.

${ }^{28}$ Gamer 40 .

${ }^{29}$ Clive Bloom, Bestsellers: Popular Fiction since 1900 (Basingstoke: Palgrave Macmillan, 2002) 9-10.
} 
Female Gothic is easily defined: the work that women writers have done in the literary mode that, since the eighteenth century, we have called the Gothic. But what I mean - or anyone else means by "the Gothic" is not so easily stated except that it has to do with fear. In Gothic writings, fantasy predominates over reality, the strange over the commonplace, and the supernatural over the natural, with one definite auctorial intent: to scare. ${ }^{30}$

For Moers, the femaleness of the Gothic text is determined by its author's gender, and the Gothicness, although complex, is determined by the author's intent to frighten. Moers relates fear not to the mind but to the body, and this, she believes, is how we can distinguish the Gothic from the tragic. Instead of triggering a psychic catharsis, the Gothic ought to make our hair stand on end and our flesh creep. ${ }^{31}$ She does, however, allow the genre a concern beyond the corporeal, associating the Gothic with a 'vague paranoia of the modern spirit', with Freudian processes involving repressed incestuous desires, and with a certain therapeutic potential. ${ }^{32}$ In making these connections, Moers proposes many of the themes that continue to interest Gothic criticism.

Earlier critics were not blind to the potentially serious concerns of Gothic narratives. Mario Praz, Devendra P. Varma and G.R. Thompson all discussed the Gothic within the framework of Romanticism. ${ }^{33}$ Yet these sorts of claims were balanced against others. Varma took the genre seriously, but also described it as 'tinged with whimsicality and passion, often chaotic and full of wonders... a key to an imaginative vision of a thrilling world... stimulating to the cramped fancy of the

\footnotetext{
${ }^{30}$ Ellen Moers, Literary Women (London: The Women's Press, 1980) 90.

${ }^{31}$ Moers 90-1.

${ }^{32}$ Moers 91, 105-9.

${ }^{33}$ Mario Praz, The Romantic Agony, trans. Angus Davidson (Oxford: Oxford UP, 1933); Thompson,

"Romanticism and the Gothic Imagination" 1-7; Varma 23-41, 206-31.
} 
age'. ${ }^{34}$ Susan Sontag described the Gothic novel as one of the 'origins of Camp taste' in the eighteenth century, and thus as containing 'a large element of artifice'. ${ }^{35}$ These earlier versions of the genre limit it in two significant ways. It is regarded as being of primarily historical interest, in that it is related to the eighteenth century and Romanticism. It is also seen as being escapist and inauthentic, as not immediately involved in the world. Moers reframes the Gothic as a timely political intervention, believing that "young women novelists and poets of today... are finding in the trauma of inexperienced and unassisted motherhood a mine of troubled fantasy and black humour [and] are on the lookout for Gothic predecessors... ${ }^{36}$ Moers insists that the genre is vitally contemporary, politically loaded, psychically engaged, even involved in the body. Moers invention of the female Gothic, viewed retrospectively, becomes a turning point in the field, allowing new values to be attached to the genre.

Gilbert and Gubar capitalised on Moers' argument, significantly modifying it in their landmark The Madwoman in the Attic. Where Moers confined her discussion to a conservatively selected group of texts, even pausing to consider whether it is fair to classify Wuthering Heights as a Gothic, ${ }^{37}$ Gilbert and Gubar tied the Gothic to women's writing in a much wider sense. Their central metaphor, the woman writer as the madwoman locked in literature's attic, is richly suggestive, and of course, draws on the horrors (and fantasies) of entrapment that often feature in the Gothic. The genre is placed at the core of an approach to nineteenth century female writers and their works. They argue that in the female Gothic:

heroines who characteristically inhabit mysteriously intricate or uncomfortably stifling houses are often seen as captured, fettered, trapped, even buried alive. But other kinds of work by women novels of manners, domestic tales, lyric poems - also show the

\footnotetext{
${ }^{34}$ Varma 210.

${ }^{35}$ Susan Sontag, "Notes on Camp," A Susan Sontag Reader (New York: Farrar, Straus and Giroux, 1982) $108,109$.

${ }^{36}$ Moers 97.

${ }^{37}$ Moers 99.
} 
same concern with spatial constructions. From Anne Radcliffe's melodramatic dungeons to Jane Austen's mirrored parlors... imagery of enclosure reflects the woman writer's own discomfort, her sense of powerlessness, her fear that she inhabits alien and incomprehensible places. Indeed, it reflects her growing suspicion that what the nineteenth century called "woman's place" is itself irrational and strange. ${ }^{38}$

Gilbert and Gubar situate their own work as a development of Moers', although here, their argument is a very substantial expansion of her ideas. Without necessarily loosening the meaning of the word Gothic so that it naturally includes Austen's text, Gilbert and Gubar nevertheless suggest an association. As discussed above, architectural and subcultural styles have become associated with the term, Gothic; but here, rather than seeing this association develop through common usage outside the academy, criticism attempts to achieve something similar, promoting a new way of understanding the Gothic. Whatever the Gothic was for Moers, it did not include the novel of manners, which is devoid of the authorial intent to frighten. By arguing that the confined woman is a key identifier of the female Gothic, even when this trope appears in types of literature that, until that point, had not been understood as Gothic, Gilbert and Gubar significantly expanded the potential scope of all discourse on the Gothic, and attached further political value to it.

Through this deft rearrangement, Gilbert and Gubar are able to read Northanger Abbey as if it is actually a Gothic rather than a parody. They understand Catherine's famous comic discovery thus: 'Catherine discovers in the old-fashioned black cabinet something just as awful as a lost manuscript detailing a nun's story. Could Austen be pointing at the real threat to women's happiness when she describes her heroine finding a laundry list? ${ }^{39}$ In terms of developing a feminist position from which to explore the text, it may be a useful reading; in terms of understanding of Austen's sly relationship with the Gothic, it is an impediment. Gilbert and Gubar

\footnotetext{
${ }^{38}$ Sandra M. Gilbert and Susan Gubar, The Madwoman in the Attic: The Woman Writer and the Nineteenth-Century Literary Imagination, Yale Nota Bene, 2nd ed. (New Haven: Yale UP, 2000) 83-4.

${ }^{39}$ Gilbert and Gubar 35.
} 
deliberately misrecognise Austen's gag while making their own, reading an object that is inauthentically, jokily Gothic as loaded with unironic Gothic threat.

This interpretation does not sit easily with Catherine's realisation the next morning, where she distinguishes between Gothic fantasy and the banal real:

Could not the adventure of the chest have taught her wisdom?... To suppose that a manuscript of so many generations back could have remained undiscovered in a room such as that, so modern, so habitable! - or that she should be the first to possess the skill of unlocking a cabinet, the key of which was open to all! ${ }^{40}$

The list imparts hidden knowledge, but only through Catherine's ability to recognise her own folly. Austen expects both her readers and her heroines to spot a sham. The 'perfect happiness' that awaits Catherine at Woodston, I hope, does not include much by way of laundry duties. Gilbert and Gubar's reading deemphasises Catherine's agency, her ability to learn. More significantly, in terms of the present discussion, Gilbert and Gubar go on to argue that the General, and by extension, Henry Tilney, are genuinely villainous, working towards Catherine's 'fall' into the humdrum of everyday life. They conclude, without their tongues in their cheeks, that

Northanger Abbey is, finally a gothic story as frightening as any told by Mrs. Radcliffe, for the evil it describes is the horror described by writers as dissimilar as Charlotte Perkins Gilman, Phyllis Chester, and Sylvia Plath, the terror and self-loathing that results when a woman is made to disregard her own personal sense of danger, to accept as real what contradicts her perception of her own situation. ${ }^{41}$

This constitutes a significant re-reading of Northanger Abbey's conclusion, where there may be a hint of Austenian prickle in the 'perfect happiness' promised, but also

\footnotetext{
${ }^{40}$ Austen 164.

${ }^{41}$ Gilbert and Gubar 143.
} 
an unequivocal defence of the General's supposed 'parental tyranny'. ${ }^{42}$ I agree with Gilbert and Gubar that Austen gives a prim redress to the excesses and errors of (patriarchal) power within the genteel English classes; but it is unnecessary to radically re-read her texts to see this.

Gilbert and Gubar's argument substantially expands the scope of the Gothic, which is no longer confined to the brightly coloured narratives of Vathek or The Monk, or the sombre, haunting tones of The Mysteries of Udolpho - all texts carefully set in exotic spaces and times, distinct from their audience's lifeworld. Instead, the Gothic now includes the dishwater dullness of the everyday, of domestic labour. Gilbert and Gubar suggest that a woman's home becomes her own Gothic castle. Heroine and authoress, stand-ins for the female subject in general, are assaulted by moribund domesticity and the enforcement of suffocating gender roles; this domestic drama is projected into the struggle of the heroine within the gloomy walls of the haunted citadel. Without explicitly confronting Moers' earlier definition, Gilbert and Gubar formulate an inversion of it while claiming only to develop the notion. For Moers, the female Gothic, while retaining an important contemporary relevance, was explicitly not about the everyday, but was instead a type of text where 'fantasy predominates over reality'. 43

Gilbert and Gubar generally explore examples that are 'commonsense' Gothics, central to any twentieth-century conception of the field, and readily identifiable by readers as such, including Radcliffe's romances and the Brontës' works. Wuthering Heights and Jane Eyre might represent transformations of the genre in that they are not set in times and places distant from their contemporary audiences. However, they are novels where dark secrets, monstrous passions and eerie milieu are central to their action, and contain frightful or frightening sequences. Yet with their treatment of Northanger Abbey, Gilbert and Gubar begin to efface the difference between the Gothic and the not-Gothic; the boundary starts to blur.

More interesting than this single act of critical license is the style of argumentation it introduced to the critical field at an early point. Gilbert and Gubar take things not recognised as typically Gothic (a laundry list, a happy ending), and

\footnotetext{
${ }^{42}$ Austen 235.

${ }^{43}$ Moers 90.
} 
'find' the Gothic within them. A single trope is enough to mark a text as having significant Gothic dimension, rather than the whole reading experience it provides. This process of loading an object or scenario with threat, effectively creating something that can be understood as Gothic, is what we expect when we read a Gothic tale, not Gothic criticism. This practice has developed, largely unremarked, as Gothic studies has grown. In this formulation, the Gothic is not just a popular and recognisable type of text; it has become a term that is appointed through critical argument, present in texts that the common, non-academic reader is unlikely to recognise as such. Popular audiences are not the arbiters of whether a production is or is not Gothic; critics are.

At the same time as enabling critics to discover the Gothic in all manner of texts, Gilbert and Gubar reduce the specificity of Gothic scenarios and tropes, so that all houses are potentially Gothic spaces of enclosure. Yet, in Udolpho, cited by Gilbert and Gubar as exemplary in its dungeonism and depiction of threat to the female subject, only about a third of the action occurs within Udolpho itself, and Emily St Aubert desperately wants to return to her home in La Vallée, 'the retreat of goodness, wisdom and domestic blessedness! ${ }^{44}$ Nevertheless, for Gilbert and Gubar, Udolpho represents Emily's home, even though, if we take Radcliffe's text as a whole, the castle exists as a counterpoint to the home. Gilbert and Gubar's argument does not account for why Udolpho might feature a transposition of values across these sites. Something similar occurs when Gilbert and Gubar suggest Udolpho is a narrative of female powerlessness, the madwoman's experience. ${ }^{45}$ While Emily's experience in the castle does frighten her, she can hardly be considered mad. In fact, the nun Agnes is much more obviously touched by madness and misery; the comparison of hysterical Agnes with sensitive but prudent Emily emphasises Emily's decorum, rationality and sanity. Emily feels 'extreme concern' and 'compassion' for Agnes as she dies, but does not identify with her. ${ }^{46}$ Rather than engaging with the entirety of a Gothic text, Gilbert and Gubar establish a critical procedure where any

\footnotetext{
${ }^{44}$ Ann Radcliffe, The Mysteries of Udolpho: A Romance, Interspersed with Some Pieces of Poetry, Oxford English Novels, ed. Bonamy Dobree (1794; London: Oxford UP, 1966) 672.

${ }^{45}$ Gilbert and Gubar 619-20.

${ }^{46}$ Radcliffe $640-3$.
} 
single element might be extracted from a text and shown to hold Gothic potential. Texts are not treated as organic wholes. The castle, the un-home, becomes the home; Emily, the un-madwoman, is made into a madwoman.

The female Gothic was instrumental in attracting wider academic attention to the genre. Punter, unlike Moers and Gilbert and Gubar, remained actively involved in Gothic studies, and capitalised on the seriousness and contemporary relevance that had recently been attributed to the genre in The Literature of Terror. He notes that the term 'Gothic' was becoming unmoored from a historically circumscribed period as he was writing, beginning to denote a wider literary tradition. ${ }^{47}$ In fact, this 'new' usage is simply another term for the tradition H.P. Lovecraft had described as the 'weird' half a century earlier in his essay 'Supernatural Horror in Literature'. Nevertheless, Punter's observation gives an indication that a specific academic field was developing.

Punter deployed both Freud and Marx to examine the genre. ${ }^{48}$ He argues that the Gothic text attempts to tell us truths about the world and ourselves even as it depicts outlandish fantasies and that 'Gothic fiction becomes a process of cultural self-analysis'. ${ }^{49}$ The genre is given a definite function, and is described in terms that suggest that critical scrutiny will yield results worthy of the effort, just as any other work of literature might. A contemporary review noted that Punter 'forces us to reexamine the Gothic in a more serious, thoughtful manner than hitherto. ${ }^{50}$ Indeed, as postmodernism's fascination with applying serious analysis to popular cultural forms developed over the course of the seventies, Punter's work must have seemed timely.

By 1982, Linda Bayer-Berenbaum could observe the 'renaissance' the genre had experienced over the previous ten years; the Gothic had 'become a household word'. Moreover, she felt 'Gothicism has gained a sense of academic respectability as

\footnotetext{
${ }^{47}$ Punter, Literature of Terror 15.

${ }^{48}$ Punter, Literature of Terror ix-X.

${ }^{49}$ Punter, Literature of Terror 408, 425.

${ }^{50}$ Gisela Casines, "Elements of the Gothic," rev. of The Literature of Terror, by David Punter, $\underline{\text { Science }}$ Fiction Studies 9.3 (1982).
} 
it has grown in popularity', linking renewed academic interest in the genre to its recent popular manifestations, especially The Exorcist and Rosemary's Baby. ${ }^{51}$ The Gothic, if it ever needed to be, had been more than recuperated, and had acquired a critical milieu, a growing body of associations, ideas and values. The critics of the late seventies and early eighties succeeded in developing a position that allowed later critics to undertake further work in the field, and their argumentative strategies continue to influence criticism.

Critical discussions of the genre can be characterised by a handful of themes, which can be traced back to the arguments that established Gothic studies as a field. The Gothic text is thought to have a direct interest in the 'real world', a significant historicity and a genuine political engagement. This might result in the examinations of the oppression of the female subject discussed here, but could equally apply to the Teresa Goddu's argument that the American Gothic is a site in which the States' troubled racial history has been scrutinised, ${ }^{52}$ or Sedgwick's claims for the genre's relevance to contemporary manifestations of homophobia, and even the AIDS epidemic. $^{53}$

At the same time, the notion of the Gothic as a genre of unusual psychological depth and engagement is common. Sedgwick links the Gothic to hysterical and paranoid psychological states, a continuation of the interest expressed in the repression of the female subject in Gilbert and Gubar. Todorov had already discussed Gothic fictions in terms of Freud's uncanny; ${ }^{54}$ Freud's essay is of course relevant to the field as it is, in large part, a discussion of one of Hoffman's macabre tales and its supposed ability to generate an uneasy reaction. In a not dissimilar vein, George Haggerty argues that the Gothic is an 'affective form', ${ }^{55}$ although it is worth noting that form is not much emphasised in Gothic criticism, probably due to the legion

\footnotetext{
${ }^{51}$ Linda Bayer-Berenbaum, The Gothic Imagination: Expansion in Gothic Literature and Art (Rutherford, NJ: Fairleigh Dickinson University Press, 1982) 11.

${ }^{52}$ Goddu.

${ }^{53}$ Sedgwick xii.

${ }^{54}$ Todorov, The Fantastic 41-57.

${ }^{55}$ George E. Haggerty, Gothic Fiction/Gothic Form (University Park: Pennsylvania State UP, 1989) 13.
} 
manifestations of the genre. Arguments for the psychological interest of the Gothic extend beyond obviously Gothic texts; for Anne Williams, Freud's case studies are a type of Gothic. ${ }^{56}$ Gothic studies links the genre to real-world suffering and trauma. Where Walpole's preface to Otranto explicitly framed his text as escapist, a reaction to the literature of 'common life' where 'the great resources of fancy have been dammed up, ${ }^{57}$ Gothic studies points towards the real; there is little sense that the genre might be entertainment.

Accompanying these critical themes is a tendency to privilege trope as an identifier of the Gothic text. Isolating tropes from wider textual arrangements allowed Gilbert and Gubar to make their expansive arguments; Sedgwick was explicit about her use of this method. Discussing tropes such as the veil, live burial and the unspeakable, she notes that her approach 'has been to apply these thematic names to fictional elements at every level, with the greatest elasticity that is consistent with maintaining a steady sense of their underlying presence'. ${ }^{58}$ Later Gothic criticism has embraced this approach. Punter writes that

we live in a world peopled by ghosts, phantoms, spectres. There are, Derrida assures us from within a long tradition, spectres haunting Europe, or haunting the West; there are, Abraham and Torok affirm, phantoms haunting and distorting the process of psychological transmission down the generations. There are, theorists of postmodernism assert, perhaps only simulacra; entranced by the flickering glow of the new technologies, our bodies vanish from our apprehension, leaving only media constructs, apparitions of desire, hungry revenants whose appetite is matched only by their impotence. ${ }^{59}$

\footnotetext{
${ }^{56}$ Williams, Art of Darkness 239-48.

${ }^{57}$ Horace Walpole, The Castle of Otranto: A Gothic Story (1764; London: Oxford UP, 1964) 7.

${ }^{58}$ Sedgwick 5.

${ }^{59}$ David Punter, Introduction, "Of Apparitions," Spectral Readings: Towards a Gothic Geography, ed. Glennis Byron and David Punter (Basingstoke: Palgrave Macmillan, 2002) 1.
} 
In Gothic narratives, ghosts typically hold a fictive realness prior to being potential containers of metaphorical meaning. Punter, however, is drawing on theoretical discussions that understand wraiths as exclusively metaphorical in nature; as if there were little difference between a ghost tale and a work of criticism. Derrida's (and Marx's) spectres are not the same thing as the Gothic's literal presentations of the ghost-trope. Alexandra Warwick complains that readings of this nature confuse 'linguistic with phenomenal reality. ${ }^{60}$ The boundary between the Gothic and Gothic criticism becomes ever thinner. At the International Gothic Association conference in 2009 , one of the keynote speakers entirely abandoned any distinction between critique and Gothic authorship, presenting an address that, while entertaining and critically relevant, took as its subject an urban legend and speculative science invented by the speaker, but presented as factual. ${ }^{61}$

As Gothic studies has developed as a field and defined its interests, the range of texts considered as Gothics has expanded considerably, in some cases outside of the academy, but especially within it. As early as 1991, an extract from Martin Amis' London Fields was anthologised in a collection declaring the presence of the "new gothic'. ${ }^{62}$ Amis is not generally received as a Gothic writer, but it is possible to see how the common reader might think the attribution fair; Amis' satire is vicious and London Fields is a grotesque narrative. Likewise, it might not seem unreasonable to read a critical volume entitled Gothic Shakespeares ${ }^{63}$ However, critical discussions of the Gothic have now extended to Waugh's A Handful of Dust, ${ }^{64}$ cyberpunk writer

\footnotetext{
${ }^{60}$ Alexandra Warwick, "Feeling Gothicky?" Gothic Studies 9.1 (2007): 9.

${ }^{61}$ Sarah Kember, "Metamorphoses," Monstrous Media/Spectral Subjects, International Gothic Association Conference, Lancaster University, 22 July 2009.

${ }^{62}$ Patrick McGrath and Bradford Morrow, eds., The New Gothic: A Collection of Contemporary Gothic Fiction (London: Picador, 1993).

${ }^{63}$ John Drakakis and Dale Townshend, eds., Gothic Shakespeares. Accents on Shakespeare. (Abingdon: Routledge, 2008).

${ }^{64}$ Horner and Zlosnik 96-101.
} 
William Gibson, ${ }^{65}$ the Oprah Winfrey show, ${ }^{66}$ the Vietnam War, ${ }^{67}$ colonial tin structures, ${ }^{68}$ and the language of theory itself. ${ }^{69}$ Certainly, some of these things might legitimately be understood as Gothic texts, but taken together, they represent a radical expansion of the term and rely not on a commonsense categorisation of the texts, but on critical arguments that claim they contain Gothic elements unrecognised by the common reader. Using this strategy, the Gothic can be 'discovered' in almost any text, and the area that Gothic studies concerns itself with becomes potentially enormous. A genre with roots in the popular and the recognisable is now thought to appear in forms utterly unrecognisable to the non-specialist. Given the expansion of the term to include such a diverse range of texts, it is unsurprising that critical definitions of the Gothic have tended to remain loose, but this lack of precision is now close to rendering the term near meaningless. ${ }^{70}$

Examining a specific instance of these claims suggests how troubling the methods of Gothic criticism have become and how it is no longer able 'to distinguish its supposed object'. ${ }^{71}$ In 'Kitschen Witches: Martha Stewart: Gothic Housewife, Corporate CEO', an article recently published in the well-known Journal of Popular Culture, Emily Jane Cohen uses the critical rhetoric of the Gothic to describe Stewart as a paragon of the American domestic tradition, ruthlessly persecuted by the media. Apparently 'the vortex of publicity surrounding [Stewart] is the peculiar legacy of a

\footnotetext{
${ }^{65}$ David Punter and Glennis Byron, The Gothic (Oxford: Blackwell Publishing, 2004) 119-20.

${ }^{66}$ Edmundson 57, 73.

${ }^{67}$ Jeanette Idiart and Jennifer Schulz, "American Gothic Landscapes: The New World to Vietnam," Spectral Readings: Towards a Gothic Geography, eds. Glennis Byron and David Punter (Basingstoke: Palgrave Macmillan, 2002).

${ }^{68}$ Ian Lochhead, "Corrugated Iron Gothic," Gothic NZ: The Darker Side of Kiwi Culture, eds. Misha Kavka, Jennifer Lawn and Mary Paul (Dunedin: Otago UP, 2006).

${ }^{69}$ Edmundson 40; Punter, "Of Apparitions" 1.

${ }^{70}$ Warwick 6.

${ }^{71}$ Baldick and Mighall 209, 216.
} 
contemporary form of American Gothic' ${ }^{72}$ Martha Stewart, of course, is the allAmerican, billionaire doyenne of a particular brand of home entertaining and tasteful living; ${ }^{73}$ she is also famous for serving a short prison term related to charges of insider trading. The thrust of Cohen's argument is simple enough: she demonstrates the ways in which Stewart is Gothic by suggesting how like a number of Gothic things she is. For instance, she claims that Stewart is a figure who is like a witch, but who is also like Hester Prynne, heroine of The Scarlet Letter. ${ }^{74}$ She believes Stewart has been subjected to a kind of witch-hunt $;^{75}$ further, she argues that Stewart is involved with the domestic realm, the hearth, a locus of Freud's notion of uncanniness, which is often associated with the Gothic. ${ }^{76}$ Thus, through association and likeness, strategies common in the field, Cohen argues Stewart is a Gothic housewife.

Just as Punter muddles metaphorical spectres with 'real' ones, when Cohen suggests that Stewart is witch-like, she does not mean Martha has entered into a compact with the devil and suckles a familiar from a supernumerary teat. While this is the kind of witch historically described in Gothic texts, Cohen actually means something relating to the renovation of the witch-figure in the latter half of the last century. ${ }^{77}$ Stewart is like a witch because she is a powerful woman, capable of brewing up mysterious, magical concoctions; or at least cooking for a dinner party of twelve without breaking a sweat. While there are Gothics which feature such transfigured witches, such as Anne Rice's Mayfair Chronicles, by not acknowledging the way the values and ideas attached to the witch as a trope alter through history, a

\footnotetext{
${ }^{72}$ Emily Jane Cohen, "Kitschen Witches: Martha Stewart: Gothic Housewife, Corporate CEO," The Journal of Popular Culture 38.4 (2005): 651.

${ }^{73}$ Movers and Shakers: The 100 Most Influential Figures in Modern Business, Ultimate Business Library (Cambridge, MA: Basic Books, 2003) 317.

${ }^{74}$ Cohen 651.

${ }^{75}$ Cohen 659.

${ }^{76}$ Cohen 653-4.

${ }^{77}$ See Diana Purkiss, The Witch in History: Early Modern and Twentieth-Century Representations (London: Routledge, 1996) 8-9, 30-8, 42-3.
} 
phenomenon which occurs with any popular motif or figure, Cohen's argument loses precision.

More confounding, however, is the way that in the very same paragraph that Cohen asserts that Stewart is a witch, she also ascribes a Hester Prynne-like quality to her. ${ }^{78}$ Hester Prynne's persecution has an obviously moral, even tragic dimension, whereas Stewart was found guilty of perjury and obstruction of justice in the wake of a far-from-ethical insider trading scandal; it is unjust that Hester suffers, while it is just that Stewart was jailed. Cohen reduces the complexity of Hester's situation to an imprecise trope, the persecuted woman. Regardless of how tenuous the comparison may be, Cohen's argument hinges on the idea of likeness. Stewart is like a witch, and like Hester Prynne. Yet she is not actually either of these things; even if we agree that witches and Hester Prynne are 'Gothic things', Stewart is only like a Gothic thing. However, if we follow Cohen's argument, Stewart becomes Gothic by her likeness. Similarity becomes substance.

Another problem emerges: how is it possible to be Hester Prynne-like and witch-like at the same time? Hester might be a mysterious and strong woman, but she is not a witch. We can be certain of this because there is an actual witch depicted in The Scarlet Letter, Mistress Hibbins, and she is a figure of an entirely different order to Hester. It is not so much the implicit contradiction in Cohen's claim that is interesting, but what it suggests about the way Cohen conceptualises the Gothic. Cohen uses the figure of the persecuted outsider, in Hester Prynne, and the figure of the witch almost interchangeably; to her, they are compatible ways to suggest that Martha Stewart 'is Gothic'. In this argument, they become the same thing; categories are blurred and shades of meaning important to Gothic narrative are lost. We can no longer tell one Gothic thing from another.

Cohen's second claim for Stewart's Gothicness is that she has been hunted like a witch. Witch-hunts are common enough in Gothic narrative, but again, Stewart was not actually accused of souring the milk and spooking the horses. Stewart is only like a witch, and the media attention gathered by her trial is only like a witch-hunt. The trope might be transferable, but the imaginative experience is utterly different. The other concern here is that just as there is a figure much more like a witch than

\footnotetext{
${ }^{78}$ Cohen 651.
} 
Hester available in The Scarlet Letter, there were phenomena a great deal more like witch-hunts present in contemporary American culture: the Satanic child abuse panics of the eighties and nineties, where bizarre and often occult allegations were made, and crimes that never occurred were confessed to. ${ }^{79}$ Cohen's argument works through a rearrangement where a weakly metaphoric witch-hunt supplants a practice that is much more similar to witch-hunting.

The real heart of Cohen's article is the Gothicness of domesticity. She argues

Whether we accept the transhistorical terms of Freudian psychoanalysis so often used to account for the Gothic, the Unheimlich, or uncanny, tends to revolve around the hearth... infernal images routinely pervert the ideal of domestic bliss. ${ }^{80}$

Freud's essay does have a kind of canonical status within Gothic studies, but Cohen makes a peculiar leap here. Because Freud involves the hearth in his discussion of the uncanny, it seems that the home is now an intrinsically Gothic site, and Stewart, associated with homemaking, becomes an exemplar of this. As a notion, the Gothic has apparently become contagious:

as the production of gadgets, appliances, and packaged food increased in industrialized nations, the home, inextricably linked to the marketplace, no longer could claim transcendent status. Americans still paid lip service to it as spiritual center, but the women who relied on new shortcuts - ranging from modern stoves to chemical leavenings and Jell-O unwittingly contributed to the decline of their own standing, for the consequent loss of craft skills rendered their tasks unrewarding and made household chores appear worthless to others. Wives became commodities of sorts,

\footnotetext{
${ }^{79}$ See Bill Ellis, Raising the Devil: Satanism, New Religions, and the Media (Lexington: The UP of Kentucky, 2000); David Frankfurter, Evil Incarnate: Rumours of Demonic Conspiracy and Satanic Abuse in History (Princeton: Princeton UP, 2006)

${ }^{80}$ Cohen 653-4.
} 
mechanical dolls gussied up to confer status on their owners, bearers of the real purchasing power. ${ }^{81}$

Perhaps this is so, but it is not necessarily uncanny and certainly is not Gothic in any way that might be understood by a common reader. Cohen's metaphor shifts again to another, more recent Gothic trope, the Stepford wife, where a woman is replaced by a robotic doppelgänger of herself. It is worth noting the shape of Cohen's argument. She tells us a story about a supposedly Gothic figure (the Stepford-Witch-MarthaPrynne composite), caught in a Gothic narrative (the witch-hunt), elaborating a Gothic theme (the uncanny). This is an article about an allegedly Gothic manifestation, yet it gives us many of the things we would expect to find in a Gothic tale. This is not a localised problem; Cohen's article is just a good example of a common discursive approach. The problem this mode of argument presents is that the Gothic becomes unlimited. What does it mean to label something Gothic? And if we cannot adequately describe what the Gothic positively is, can we even define what it is not?

It can suggest a lot of things when a text is labelled as Gothic, but perhaps the first is that it has been placed in a category. Regardless of how the term is defined, the Gothic refers to a category of literature, or, in a wider sense, a category of cultural production including film, the visual arts, videogames, comic books, even music and fashion. When we think of texts as belonging to a category, it enables us to think of them as having something to do with one another, as naturally belonging together. George Lakoff notes that we tend to organise categories into hierarchies so that some are superordinate, others subordinate, and they form a hierarchical chain. ${ }^{82}$ This is significant for the way the study of the Gothic is organised. Subcategories of the Gothic are identified to pragmatically define areas of study, and to usefully suggest 'family resemblances' between texts; each, in its way, also represents an expansion of the genre.

\footnotetext{
${ }^{81}$ Cohen 658.

${ }^{82}$ George Lakoff, Women, Fire, and Dangerous Things: What Categories Reveal About the Mind

(Chicago: U of Chicago P, 1987) 31-8.
} 
The first of these subcategories, before the advent of a female Gothic, is the Southern Gothic, a term that appeared shortly after Faulkner began to attract recognition. The earliest attribution of a 'Gothic' function to Faulkner's work I have found is in a critical essay from $1934{ }^{83}$ in 1937 , his work is referred to as a 'kind of Gothic creation'. ${ }^{84}$ The term 'Southern Gothic' was in wider critical use by the early fifties. ${ }^{85}$ This subcategorisation is significant, as it seems to be the first usage of the term 'Gothic' to describe twentieth century writing. Where Walpole and Reeve used the term as a subtitle to describe the difference of their texts, and Radcliffe and Hawthorne used the term 'romance' in a similar way, the Southern Gothic emerged as a critical appellation. Looking back at the emergence of the term reminds us that as natural as these subcategories seem, unlike the original Gothic, they remain critically constructed. In turn, the difference between the Southern Gothic and the subgeneric labels that follow is that Southern Gothic emerged slowly out of an ongoing critical discussion rather than from a single critical declaration intended as originary.

As Gothic studies developed, further subcategories followed. Now we read of 'imperial Gothic', 'postcolonial Gothic', 'suburban Gothic', any number of national Gothics, 'cybergothic', even 'postfeminist Gothic'. ${ }^{86}$ What was once referred to as 'the' Gothic - the works of Walpole, Lewis, Radcliffe and so forth - has become just another subcategory, the 'original eighteenth century Gothic', sitting alongside many others. The peculiar side-effect of the creation of these subordinate categories and the

\footnotetext{
${ }^{83}$ Harlan Hatcher, "The Torches of Violence," The English Journal 23.2 (1934): 92.

${ }^{84}$ Stark Young, "Golden Apples," The English Journal 26.9 (1937): 697.

${ }^{85}$ In the early fifties, critics remained careful to explain themselves when using the term, hinting at its newness. In 1951, a critic wrote in regard to the reception of Carson McCullers, that her work was 'another late flowering of Southern Gothic, a literary tradition powerfully exemplified but transcended in the novels of William Faulkner and now going to seed in the baroque fantasies of Truman Capote'; Dayton Kohler, "Carson McCullers: Variations on a Theme," The English Journal 40.8 (1951): 415. In 1952, in reference to Eudora Welty's 'Clytie', Granville Hicks wrote, 'This might well be called Southern Gothic'; Granville Hicks, "Eudora Welty," College English 14.2 (1952): 70. This phrasing also suggests the term was still in the process of being constructed. By 1963, the Southern Gothic, more-or-less as we have it now, is described by Chester E. Eisinger, in Fiction of the Forties (Chicago: U of Chicago P, 1963) 235-89.

${ }^{86}$ See, for instance, the organisation of the primarily pedagogical Punter and Byron, The Gothic.
} 
placement of texts within them is that the superordinate category that is simply 'Gothic' has been emptied of texts. Through this empty category, very different texts, that appeared in very different times and places, can be read as alike, especially by critics who emphasise the tropological constancy of Gothic texts, or those who favour a psychoanalytic approach. This has become a resource for critics who wish to expand the genre's scope.

Lakoff observes a further property of categorical thinking: when we think of the complement of a category, that is, all the things that do not belong to a category, we have no clear mental image of what this might mean. If, for instance, we talk about a chair, we might mean a rocking chair or an armchair or a desk chair, a number of configurations are included in the category; but we have no real idea what a notchair positively is. ${ }^{87}$ This is the difficulty we face when we study the Gothic; we are unable to articulate what the Gothic is not. Lakoff's account of the way category functions is a good description of the way that Gothic studies often conceives of the genre. Because we cannot say with certainty that Martha Stewart is not Gothic, it has been possible to argue that she is.

Compounding this problem, as Avril Horner and Sue Zlosnik recently noted, the Gothic 'is both temporally and culturally inflected - what terrified the eighteenthcentury reader will not frighten the twenty-first century cyberspace surfer' ${ }^{88}$ Indeed, the twenty-first century reader might be hard pressed to recognise the eighteenth century Gothic at all. The gentle supernaturalism and legalistic fixations of Reeve's The Old English Baron, for instance, are not what the contemporary reader thinks of when they think of the Gothic. As Fred Botting suggests, the Gothic, and especially the contemporary Gothic, has undergone a transvaluation.$^{89}$ If the Gothic is not what it used to be, then we need to acknowledge the changeability of the term, and it is not adequate to simply return to the eighteenth-century texts as some kind of ur-Gothic blueprint. Carolyn R. Miller argues that 'a genre that seems to occur in two rather

\footnotetext{
${ }^{87}$ Lakoff 52.

${ }^{88}$ Horner and Zlosnik 2.

${ }^{89}$ Fred Botting, Preface, "The Gothic," The Gothic, ed. Fred Botting, Essays and Studies 54

(Cambridge: D.S. Brewer, 2001) 3.
} 
distinct times and places will not really be "the same" in an important sense'. ${ }^{90}$ The Gothic is both dynamic and limited, in that it is different to what it once was, yet it is possible to trace its development through continuous, although sometimes quite substantial, movements. So, while the way I use the term 'Gothic' includes the eighteenth century texts from which we take the term, I do not mean to privilege these texts in the wider field. Precise terms for the Gothic, and the particular emphases of the genre that accompany them, come and go. A theorisation of a genre like the Gothic needs to account for its mutability.

Theorisations of genre from the later part of the twentieth century have engaged with the historical and changeable nature of genres; yet one of the peculiar things about Gothic studies is that while it is a field defined by a genre, it seldom engages with genre theory. It is difficult to account for this failure to connect; it may be a consequence of genre theory simply not having been prominent in much twentieth century criticism. Todorov observed the twentieth century's antipathy to notions of genre, suggesting it is "considered a sign of authentic modernity in a writer if he ceases to respect the separation of genres. ${ }^{91}$ David Duff has made the related observation that, until very recently, for 'modern literary theory, few concepts have proved more problematic and unstable than that of genre... If the death of the author has been a familiar refrain of modern literary theory, so too has the dissolution of genres' ${ }^{92}$ Genre had been a central concept in criticism prior to the twentieth century, although the idea that a text might be so radically individual as to be genreless first emerged out of Romanticism. Nevertheless, there have been numerous theorisations of genre throughout the last century, ${ }^{93}$ and just as 'Gothic' has significantly altered as

\footnotetext{
${ }^{90}$ Carolyn R. Miller, "Rhetorical Community: The Cultural Basis of Genre," Genre and the New

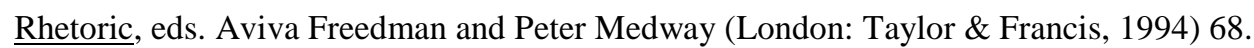

${ }^{91}$ Tzvetan Todorov, Genres in Discourse, trans. Catherine Porter (Cambridge: Cambridge UP, 1990) 13.

${ }^{92}$ David Duff, Introduction, Modern Genre Theory, ed. David Duff (Harlow: Longman, 2000) 1.

${ }^{93}$ Good recent introductions to the field include David Duff, ed., Modern Genre Theory (Harlow: Longman, 2000); and John Frow, Genre, The New Critical Idiom (Oxon: Routledge, 2006).
} 
a descriptor, so has the term 'genre'. The term as I am using it here is not far from its contemporary popular usage. ${ }^{94}$

Attempts to theorise genre and genre systems are usually thought to stretch back to Aristotle's Poetics, where comedy, epic and tragedy are discussed and defined. Duff attributes the twentieth century's move away from genre as a critical notion to the action of Romantic and modernist thought, ${ }^{95}$ presumably due to the value both placed on authenticity and originality. It is also easy to see how New Criticism, with its focus on the individual text, did not embrace genre as a critical tool. In many ways, Benedetto Croce's influential objection to the usefulness of genre remains; 'Error begins when we try to deduce the expression from the concept,' which is to say that it is a mistake to allow genre classification to make meaning. ${ }^{96}$ What is the purpose of discussing genre if it cannot help us read a text? Indeed, the very notion of 'text', so prevalent in cultural studies, acts against genre. 'Text' allows any book, indeed, any thing, regardless of the medium in which it appears and the 'reading' experience it offers, to be regarded as loosely equivalent with any other, in that anything might be 'read' using a similar approach. 'Text' potentially effaces the differences between diverse sorts of cultural production.

Earlier twentieth century approaches to genre were often informed by a structuralist sensibility. Vladimir Propp, for instance, discovered what he believed was a kind of narrative grammar arranged around a set of structural invariants ('morphemes') in the Russian folktale. ${ }^{97}$ Thus, Propp links genre to the elements of narrative that occur within it. Northrop Frye takes a similarly systemizing approach in The Anatomy of Criticism, but expands his project much further than Propp's, outlining four complementary critical approaches to literature. While Frye develops a critical system meant to encompass literature as a whole, he emphasises types of

\footnotetext{
${ }^{94}$ Duff notes the confusion associated with the term, especially whether or not genre and form are the same thing; Duff, Introduction 17.

${ }^{95}$ Duff, Introduction 4-5.

${ }^{96}$ Benedetto Croce, Aesthetic as Science of Expression and General Linguistic, trans. Douglas Ainslie, 2nd ed. (London: Macmillan, 1929) 36.

${ }^{97}$ Vladimir Propp, Morphology of the Folktale, trans. Laurence Scott, 2nd ed. (Austin: U of Texas P, 1968).
} 
literary production, and suggests ways in which commonalities and connections exist between texts. This is his system of mode (the register of the subject matter), symbol, mythos (the plot-form and the associated trappings of that form) and genre (by which Frye means formal aspects of a text, whether it is written as prose or poetry, drama or lyric, and so forth). Frye believed that genre criticism would have to be 'based on that aspect of symbolism that relates poems [or other texts] to one another' ${ }^{98}$ Gothic studies has emphasised this approach.

While Gothic narratives are unconfined by mode or genre in the sense Frye uses the terms, his discussion of mythoi has considerable potential for Gothic studies. Each separate mythos creates an expectation in its readers that they will encounter 'a certain kind of structure and mood' ${ }^{99}$ Frye treats only comedy, romance, tragedy and satire in his essay, but this could be expanded to include the Gothic at the cost of spoiling Frye's carefully balanced total system. ${ }^{100}$ It would be reductive to suggest that the Gothic reiterates a single plot form; more useful are his evocative descriptions of the fictive 'worlds' created within the mythoi. Gothics rely on atmosphere as much as action, and this is what Frye describes. Hans Robert Jauss uses the phrase 'horizon of expectation' to describe the consciousness of a given historical period; ${ }^{101}$ Frye's descriptions achieve something similar in terms of the mythoi he treats.

Jauss rejects Frye's 'archetypal' approach, instead arguing for a view of literature and genres grounded in history and historical reception. ${ }^{102}$ In this, he is typical of more recent genre theorists, who, noting the historical 'careers' that genres have, argue for their historicised basis, seeing genre as intimately involved with the

\footnotetext{
${ }^{98}$ Northrop Frye, Anatomy of Criticism: Four Essays (1957; Princeton: Princeton UP, 1990) 96.

${ }^{99}$ Frye 92.

${ }^{100}$ Frye actually describes Gothic romance as a specific kind of gloomy comedy, detached from the world. While this captures something of the mournful sort of 'original' Gothic, it does not adequately treat the real variety of Gothic texts; Frye 185-6.

${ }^{101}$ Paul de Man, Introduction, Toward an Aesthetic of Reception (Minneapolis: U of Minnesota, 1982) xi-xii.

${ }^{102}$ Hans Robert Jauss, Toward an Aesthetic of Reception, trans. Timothy Bahti (Minneapolis: U of Minnesota Press, 1982) 66.
} 
real. Todorov articulates a vision of genre as emerging from contemporary culture, following Bakhtin in arguing that, with some exceptions, 'genres stem from speech acts', and that 'Genres are the meeting place between general poetics and event-based literary history'. ${ }^{103}$ Todorov acknowledges that not all speech acts will give rise to genres, and sees those acts which do as being especially representative of the ideological moment from which they arise. However, his conceptualisation of genre, which demands that a given genre display 'historically attested codification of discursive properties', ${ }^{104}$ cannot comfortably be extended to include the enormous diversity of the Gothic, which has now achieved a substantial discursive incoherence; it is the label 'Gothic' itself that connects Radcliffe, Faulkner and zombie films, as much as a shared set of concerns.

Frederic Jameson, like Todorov, is interested in a historicised view of genre, and critiques and rearranges Propp and Frye in The Political Unconscious. He suggests that a historical understanding of genre begins with understanding its cultural function. Romance, for instance, supposedly allows its consumers to formulate ideals of good and evil in terms of identity and otherness, and reifies the expulsion of the evil other. ${ }^{105}$ Thus, argues Jameson, genre can be considered 'an ideologeme... a historically determinate conceptual or semic complex which can project itself variously in the form of a "value system" or "philosophical concept", or in the form of a protonarrative, a private or collective fantasy., ${ }^{106}$ Jameson presents this as a clarifying revision of what he sees as Frye's essentialist claims for the 'spirit', 'essence' or 'worlds' of the mythoi. For Jameson, 'historical reality' is 'disguised and diffused' inside the romance genre. ${ }^{107}$ In Jameson's view, the force of political and economic history is inescapable, even in escapist texts. Of course, historical

\footnotetext{
${ }^{103}$ Todorov, Genres in Discourse 19-20.

104 Todorov, Genres in Discourse 19.

${ }^{105}$ Fredric Jameson, The Political Unconscious: Narrative as a Socially Symbolic Act (London: Routledge, 1989) 117-9.

${ }^{106}$ Jameson 116.

${ }^{107}$ Jameson 149-50.
} 
circumstance will provide a horizon of expectation for the style and content of any text, but text is more than a distorting mirror held up to the world.

Jameson's argument supposes that all genres and texts are, finally, involved in the world. However Frye suggested a more complex relationship, claiming that literature is 'a body of hypothetical creations which is not necessarily involved in the worlds of truth and fact, nor necessarily withdrawn from them, but which may enter into any kind of relationship to them, ranging from the most to the least explicit. ${ }^{, 108}$ Frye allows that genre relates in varying degrees to the historical real, although admittedly he does not emphasise this. Jauss concurs when he claims 'literary works are variously permeable of events in historical reality'. ${ }^{109}$ Jameson favours a set relationship between text or genre and the historical real, and does not seem to allow for variability within this relationship. However, as Jauss recognises, 'Literary genres do not exist alone, but rather form the various functions of a given period's system, to which they connect the individual work' ${ }^{110}$ The way in which romance (and by extension, the Gothic) relate to the historical moment may well be different to how other genres, which co-exist with them, relate to it.

Jauss' own contribution to genre theory is to insist on a slightly different approach to historicity, focussing not on the political and economic situation that provides the historical context of a genre, but instead ascribing a history to the genre itself: 'The historicity of a literary genre stands out against a process of the shaping of its structure, its variation, extension, and correction, which can lead to its ossification, or can also end with its suppression through a new genre. ${ }^{111}$ For Jauss, genres change over the course of time, and relate to their own histories as well as their historic circumstance. This is an apt observation in relation to Gothic texts, which may equally address or evade their historical milieu, but frequently engage with their own genre.

\footnotetext{
${ }^{108}$ Frye $92-3$.

${ }^{109}$ Jauss 12.

${ }^{110}$ Jauss 106.

111 Jauss 89.
} 
Derrida would agree with this, noting that genre texts tend to 'remark' themselves as participating in their particular genres. ${ }^{112}$ However, Derrida insists on the contaminated nature of all genres; while there is no genreless text, neither is there ever really a text of a single genre. Derrida suggests genre texts abide by the 'law' of genre, and that contrarily, 'lodged within the heart of the law itself, [is] a law of impurity or a principle of contamination'. ${ }^{113}$ Texts playfully transgress the laws of genre with the law of impurity, and consequently, there is no pure instance of genre in text.

Together, these theorisations loosely represent two key approaches to genre. Frye and to some extent Propp emphasise understandings that have genres as almost ahistorical essences, constant forms that throw their shadows on the walls of a cave. Derrida complicates this view by suggesting the inconstancy and mixed nature of genre. On the other hand, Todorov, Jameson, and Jauss argue for a historicised sense of genre. While these later theorisations seem more convincing, it would be useful to develop a view of genre that began to bring together these claims. Such a view would account for the changeability of genres and their historic aspect, but also the way that genre texts refer inexactly to the historical moment that produces them. At the same time, it would explain genre's ability to seem entirely 'natural' to writers and readers, as if it were indeed a spirit or essence. It might also answer Derrida's claims for the impurity of genre by suggesting that readers are able to exclude texts from substantial membership in a genre category. Pierre Bourdieu's conceptualisation of 'habitus' can achieve this.

Bourdieu relates an experiment performed in the course of researching Distinction. Respondents commented on a series of photographs, and Bourdieu noted that 'the effort to recognise culminates in classification into a genre, or, which amounts to the same thing, in the attribution of a social use, the different genres being defined in terms of their use and their users.' ${ }^{114}$ This is a common observation in Bourdieu's

\footnotetext{
112 Jacques Derrida, "The Law of Genre," Critical Inquiry 7.1 (1980): 64.

${ }^{113}$ Derrida, "Law of Genre" 57.

${ }^{114}$ Pierre Bourdieu, Distinction: A Social Critique of the Judgement of Taste, trans. Richard Nice (Massachusetts: Harvard UP, 1984) 42.
} 
writing on art and literature, which understands that the "possible principles of division into complementary classes of the universe of representations... is in the nature of a social institution. ${ }^{115}$ The struggle for interpretation is also the struggle for classification, and this classification is historicised and related to use and users. In other words, as much as it is a categorisation, genre is also related to practice. Perhaps the Gothic is something that is done rather than something that simply is. This recalls Derrida's argument that a text participates in a genre without simply belonging to it. $^{116}$ The act of categorisation is part of a more substantial practice.

My suggestion is that the Gothic is a cultural practice that is institutionalised yet adaptable, not dissimilar to activities such as 'playing a game of football' or 'going to church.' Bourdieu usefully theorised the basis of practice, and his notions of habitus and field hold the potential to bring together many of the claims that disparate genre theorists have made. I should note that Bourdieu's own approach to cultural productions emphasised the role of cultural and symbolic capital, best expressed in Distinction. There, Bourdieu argues that classes define themselves through their consumption, ${ }^{117}$ and that consequently literature and art provide opportunities for them to define themselves. However, the suggestion that the Gothic is a form of practice draws on a different aspect of Bourdieu's thought, explicated in The Logic of Practice. Bourdieu believes that practices

have as their principle not a set of conscious, constant rules, but practical schemes, opaque to their possessors, varying according to the logic of the situation... Thus, the procedures of practical logic are rarely entirely coherent and rarely entirely incoherent. ${ }^{118}$

The procedures of practical logic are what Bourdieu calls habitus. Habitus describes

\footnotetext{
${ }^{115}$ Pierre Bourdieu, "Outline of a Sociological Theory of Art Perception," The Field of Cultural Production: Essays on Art and Literature, ed. Randal Johnson (New York: Columbia UP, 1993) 223.

${ }^{116}$ Derrida, "Law of Genre" 59.

${ }^{117}$ Bourdieu, Distinction 483.

${ }^{118}$ Pierre Bourdieu, The Logic of Practice, trans. Richard Nice (Stanford: Stanford UP, 1990) 12.
} 
systems of durable, transposable dispositions... principles which generate and organize practices and representations that can be... adapted to their outcomes without presupposing a conscious aiming at ends or an express mastery of the operations necessary in order to attain them. ${ }^{119}$

It is significant that Bourdieu places 'practices and representations' together, allowing habitus to include artistic practice and consumption.

Bourdieu developed the notion of habitus to describe canniness, commonsense knowledge, the fuzzy logic of doing, the ideal yet pragmatic and adaptable way that people undertake practices. Bourdieu's theorisation of habitus is often seen as an attempt to mediate between the deterministic structuralism suggested by thinkers like Lévi-Strauss, and the existentialist freedom of agency postulated by thinkers like Sartre. ${ }^{120}$ It is 'an acquired system of generative schemes' that shapes us as it shapes our behaviours, yet does not function as an absolute structural constraint; it is 'a present past that tends to perpetuate itself into the future by reactivation in similarly structured practices' ${ }^{121}$ The durability, transposability, partial coherence and opacity of habitus can help us understand how some genres, and especially the Gothic, are perpetuated, operate and are popularly received.

Habitus explains how it is that the common reader can instantly recognise the Gothic text, but has much more trouble explaining it. 'Objectively "regulated" and "regular" without being in any way the product of obedience to rules, [the principles that constitute habitus] can be collectively orchestrated without being the product of the organizing action of a conductor. ${ }^{122}$ Habitus still allows for individual style, manifesting within individuals belonging to a particular group or class similarly,

\footnotetext{
${ }^{119}$ Bourdieu, Logic of Practice 53.

${ }^{120}$ Pierre Bourdieu and Loïc J.D. Wacquant, An Invitation to Reflexive Sociology (Chicago: U of Chicago P, 1992) 5.

${ }^{121}$ Bourdieu, Logic of Practice 54-5.

${ }^{122}$ Bourdieu, Logic of Practice 53.
} 
without being homogenous. ${ }^{123}$ This helps to account for the different responses individual readers will have to a single Gothic text. More significantly, it helps to explain the plethora of Gothic texts extant that are extremely similar without being identical.

'Gothic habitus' is a shared way of understanding and 'doing' things we describe as Gothic. This Gothic habitus is part of the "ensemble of... dispositions" ${ }^{124}$ that constitute a person's wider habitus, although in some people, it will be more fully developed than it is in others. These people are fans or perhaps authors of the genre, and are involved in it in a more significant way than other readers are. Understood as habitus, the Gothic describes a way of writing, a way of reading, a way of thinking about stories, a way of imagining; and this description stretches to include our ability to make blackly humorous jokes, or to dress up grotesquely on Halloween. The Gothic is not as formal as a contract, is never as definite as a law or code or language, is not quite as informed, personal or idealistic as an aesthetic. It is something between the ceremonial and the ludic, and ought to be understood not as a set form, nor as an accumulation of texts and tropes, but as a historicised practice which is durable yet transposable: a habitus that orchestrates the generation of various texts and variant readings over the course of time.

Habitus accounts for how the Gothic is transmitted and forms a tradition. The Gothic text is a source of the Gothic insofar as it is part of the process of performing the Gothic, and because it is the means by which the past of the Gothic, as a practice, remains present and perpetuates itself into the future. Text represents an 'event' in Gothic practice, a lived experience as much as an opportunity to reflectively interpret; it is a device used to enact the Gothic, a kind of fetish to which values are attributed.

Understanding genre as habitus, and the reading and writing of texts as practice, gives us a sense of how tradition interfaces with the individual talent, which is useful in a field as repetitive as the Gothic. Neither habitus nor individual agents are wholly responsible for the Gothic text, but both are essential to its creation. With this recognition, we see the Gothic, and perhaps a handful of other major genres also, as endlessly iterated yet perpetually transforming, as popular epistemologies, as

\footnotetext{
${ }^{123}$ Bourdieu, Logic of Practice 60.

${ }^{124}$ Bourdieu and Wacquant 13.
} 
imaginative social practices grounded in habitus. The Gothic, so long associated with the uncanny, operates through a sort of canniness.

The idea that popular genres constitute a kind of habitus is not one Bourdieu himself emphasised. For him, reading a text was an act of decoding, and only the culturally competent reader could extract meanings that went beyond the sensible properties of a work. ${ }^{125}$ Bourdieu's approach to genre seems to have relied, at least in part, on this kind of lingual metaphor of genre as a kind of generative grammar or langue, and the manifestation of that genre within a text as a kind of parole, requiring deciphering. ${ }^{126}$ Elsewhere, Bourdieu refers specifically to literary genre as an 'instituted means of expression', which in dialectic with individual 'expressive dispositions' demonstrates the 'real logic of action', or habitus. ${ }^{127}$ Thus, Bourdieu seems not to regard genre in itself as habitus, but as a form open to manipulation by the action of agents informed by their habitus.

Habitus raises the question of agency, and while my argument does suggest that authorial intent is important in determining whether a text is Gothic, that intention is not the defining feature by which we recognise the Gothic within a text. Nor is it my aim to argue for a relocation of our interpretive act from text to audience; but to suggest that one of the most important contexts in which we should read the Gothic text is in relation to the historicised notion, contested and incomplete as it will be, of the Gothic within its time.

One of the useful differences between the idea of practice and that of category is that it is much more difficult to argue one practice into another than it is to manipulate categories. For instance, football remains recognisable as an event regardless of the circumstances in which it manifests. It could be played by teams of professionals in a stadium, with rigorous rules; it could be played by children in a playground, with much looser rules; it could simply be watched on a television, yet the watchers would still conceive themselves as participating in football. Indeed, drunken men singing a team song on the street long after a game are still, in some way, involved. Regardless of the variant arrangements of space, time, action and

\footnotetext{
${ }^{125}$ Bourdieu, Distinction 2-3.

${ }^{126}$ Bourdieu, "Outline of a Sociological Theory of Art Perception" 215, 225, 227.

${ }^{127}$ Bourdieu, Logic of Practice 57.
} 
game rules, all of these agents remain recognisably involved in football. Nobody tries to manipulate categories to suggest a game of tennis is a game of football on the basis they are both game-like.

If the Gothic is a part of our habitus, then it is a discrete and recognisable cultural phenomenon that we can observe because it is a real thing, rather than a theoretical construct.

The habitus, a product of history, produces individual and collective practices - more history - in accordance with the schemes generated by history. It ensures the active presence of past experiences, which, deposited in each organism in the form of schemes of perception, thought and action, tend to guarantee the 'correctness' of practices and their constancy over time, more reliably than all formal rules and explicit norms. ${ }^{128}$

The Gothic's limits are defined by the ability of its audience to recognise a particular text as Gothic. While the genre is constructed, it appears as totally 'natural' to participants: 'the regularities inherent in an arbitrary condition... tend to appear as necessary, even natural, since they are the basis of the schemes of perception and appreciation through which they are apprehended. ${ }^{129}$ Thus habitus explains why Frye's mythoi should feel natural, as if, as Jameson claims, they suggest that genres are a kind of spirit or essence; simply, this is our native experience of genre.

The Gothic remains an inexact formulation. The 'fuzziness' of habitus suggests the elusiveness of the genre when we analyse it; the way that discussions about doubling, the uncanny, the spectral and Otherness say something about the Gothic but never wholly capture it. The Gothic, a discrete practice, is ultimately irreducible. However, as the Gothic is a historicised cultural phenomenon it cannot, despite substantial critical effort, be constructed through argument. Gothic habitus, which exists in the main outside the academy, generates practical action; its mode of logic tends to 'common sense', and typically produces the 'regular'. While the Gothic

\footnotetext{
${ }^{128}$ Bourdieu, Logic of Practice 54.

${ }^{129}$ Bourdieu, Logic of Practice 53-4.
} 
is transposable, it maintains a 'correctness' that excludes instances like Martha Stewart, tin sheds, and so forth.

Gothic habitus suggests readers will read a Gothic text in a particular way. Having identified the text as participating in the Gothic, they read with a set of vague expectations, looking forward to the Gothic's familiar pleasures, while simultaneously hoping to be delighted by the novelty, the distinguishing features of the particular text. The way in which expectations are met or disturbed mediates, in a very practical way, the reading experience. Jauss believes 'The way in which a literary work, at the historical moment of its appearance, satisfies, surpasses, disappoints, or refutes the expectations of its first audience obviously provides a criterion for the determination of its aesthetic value. ${ }^{130}$ When readers natively understand a text, they immediately grasp the implied play of assumption, anticipation and emphasis that moves throughout it, identifying the new while accepting the conventional. This amounts to a perceptual shift. Some things will strike readers as strange and unique, while others will elude their notice. Gothic habitus allows readers to negotiate the implicit emphases that contribute to the text's creation of meaning, and allows us to understand and interpret the weirdness of Gothic conventions. Marina Warner observes of spirits that 'Nobody, except perhaps a child... finds it strange... that lost loved ones should return with arms stiffly held by their sides and wrapped head to foot in the shroud in which they were buried. ${ }^{131}$ To draw strong meanings from the conventional appearance of a ghost in a critical reading of a ghost story misses the point that a ghost appears in a certain way because that is the way that ghosts conventionally 'are'.

Bourdieu notes

one only has to suspend the commitment to the game that is implied in the feel for the game in order to reduce the world, and the actions performed in it, to absurdity, and to bring up questions about the meaning of the world and existence which people never

\footnotetext{
${ }^{130}$ Jauss 25.

${ }^{131}$ Marina Warner, Phantasmagoria: Spirit Visions, Metaphors, and Media into the Twenty-First Century (Oxford: Oxford UP, 2006) 12-13.
} 
ask when they are caught up in the game - the questions of an aesthete trapped in the instant, or an idle spectator. ${ }^{132}$

This begins to describe the position that has allowed Gothic criticism to make increasingly absurd claims for the genre. To develop authentic readings, we need to strike a balance between our critical 'play' with the text, and the limits of legibility suggested by the habitus that was at work in the field in which the text emerged and was received. Genre texts rely on their audience's ability to recognise them as being involved in a particular genre, to appropriately modify their reading position, and to distinguish the difference of their particular take on generic practice.

An instance of the failure to connect scholarly investigation with popular reading practice, similar to Warner's observation of the unstrangeness of ghosts, might be the kind of critical attention the figure of the vampire occasionally attracts. To suggest various psychoanalytic constructs in relation to biting and sucking, the penetrative properties of fangs and the orifice-like nature of the mouth, ${ }^{133}$ reduces the vampire to a generalised trope. For most readers, the phlebotomic habits of vampires are a given; mouths are a fact of the face, and fangs save the undead from having to use a straw. As much as the trope has been fetishised, there is also something unremarkable about bloodsucking. Even if we accept that vampires are important because of the method by which they feed, that hardly distinguishes what is significant about an individual vampire in a specific text. Far more interesting is the play of likeness and difference between these separate figures.

Gothic habitus is an acquired, but non-specialist knowledge. Readers usually recognise texts as Gothic with little difficulty, especially if those texts have arisen within their own, contemporary field. This seemingly instinctual, although actually learned, classificatory ability does not rely on the textual knowledge we might suppose. Readers need not have much knowledge of the Gothic canon as it is

\footnotetext{
${ }^{132}$ Bourdieu, Logic of Practice 66-7.

${ }^{133}$ For instance, see Christopher Craft, "'Kiss Me with Those Red Lips': Gender and Inversion in Bram Stoker's Dracula," eppresentations 8 (1984): 109; or Candace R Benefiel, "Blood Relations: The Gothic Perversion of the Nuclear Family in Anne Rice's Interview with the Vampire," The Journal of Popular Culture 38.2 (2004): 268. A slightly less credulous engagement with this kind of thing can be found in Ken Gelder, Reading the Vampire, Popular Fictions Series, (London: Routledge, 1994) 67, 75.
} 
critically understood in order to appreciate the latest vampire romance they happen to be consuming. Frye claims that 'the skill developed from constant practice in the direct experience of literature is a special skill, like playing the piano' ${ }^{134}$ This is the skill that is taught within the academy. Gothic practice is instead cumulatively acquired through cultural participation occurring largely outside of the academic environment. Bourdieu suggests that

So long as the work of education is not clearly institutionalized as a specific, autonomous practice... without specialized agents or specific occasions, that exerts an anonymous, diffuse pedagogic action, the essential part of the modus operandi that defines practical mastery is transmitted through practice... without rising to the level of discourse. ${ }^{135}$

Very different sorts of knowledge allow us to apprehend 'literature', on the one hand, and the Gothic on the other. Where literature is discursive, the Gothic is practical; where literature is taught and its knowledge is sanctioned, the Gothic is acquired and Gothic knowledge operates at the level of practical sense.

These binaries are not, of course, absolute. The Gothic is taught within the academy, but it is taught in academic terms, and from an academically conceived version of the Gothic 'canon'. There is an interface between popular and institutional conceptions of the Gothic that needs to be carefully addressed. Different authors have different relationships to literature and discourse. It is only recently that Stephen King was institutionally studied. On the other hand, Dickens, an occasional Gothicist, has been involved with pedagogy at almost every level for some time. Angela Carter emerged from the academy. Dennis Wheatley, on the other hand, is entirely ignored. This institutional attention is dependent not on the import of the texts as Gothics, but on their ability to double as literature or as meaningful cultural artefacts. A further point here is that the Gothic does, in fact, involve 'specialized agents' and 'specific occasions'. Horror

\footnotetext{
${ }^{134}$ Frye 28.

${ }^{135}$ Bourdieu, Logic of Practice 73-4.
} 
buffs and successful authors have an impact on the field, and conventions bring fans together. However, this institutionalisation operates at a far less formalised and sanctioned level than the academy does. Rather than the formality of the lecture theatre and scholarly papers, the Gothic recalls the unspecialised enthusiasm of Isabella Thorpe and Catherine Morland's discussions.

Gothic habitus, a general disposition, certainly does occur within agents who have acquired the 'cultivated disposition' that is typically the result of both a class background and appropriate schooling, which gives readers the ability to categorize 'by authors, by genres, by schools and by periods, for the handling of educational categories like literary analysis'; Bourdieu notes that this disposition leads to a 'tendency to acquire equivalent categories in other fields'. ${ }^{136}$ In other words, academic readers happily extend the categories and sorts of knowledge native to the academy to the Gothic text, without accounting for the different sort of practice they are engaging in. The bearer of significant cultural or symbolic capitals has the ability to define cultural productions outside of their field of experience. Bourdieu frames this as part and parcel of the advantage the cultural capitalist has when engaging with texts regardless of whether that text qualifies as 'literary' or 'sanctioned'. As much as this allows the academy to seemingly legitimately define the field, this relationship must ultimately be understood as an impediment.

Too often, Gothic studies is unable or unwilling to account for non-academic reading practices that might produce variant readings of Gothic texts. Critics typically

adopt the viewpoint of the 'impartial spectator' who seeks to understand for the sake of understanding and who tends to assign this hermeneutic intention to the agents' practice and to proceed as if they were asking themselves the questions he asks himself about them. $^{137}$

\footnotetext{
${ }^{136}$ Bourdieu, "Outline of a Sociological Theory of Art Perception" 230.

${ }^{137}$ Bourdieu, Logic of Practice 31.
} 
Bourdieu rightly asserts that there is an interest in maintaining 'disinterestedness', the hallmark of academic or 'purely' aesthetic engagement. ${ }^{138}$ If our methods of understanding have been developed within the world of letters, and the Gothic, with exceptions, exists outside the world of letters, then we will need to modify our approach to the texts; they will not be literary in the same manner that self-conscious literature is. The Gothic's critics, as much as any agent, have acquired Gothic habitus, but instead deploy reading strategies appropriate to canonised literature. This does not represent insufficient competence, but instead a misapplication of strategy that replicates insufficient competence, generating 'an illusory comprehension based on a mistaken code. ${ }^{, 139}$

'Literature' and the Gothic are different games, although the two often converge, as in 'The Turn of the Screw' or Beloved. On other occasions the two remain separate, as in the semi-pornographic vampire romances of Christine Feehan. In cases where a text is involved in multiple genres we need to orchestrate and ordinate our readings to produce a balanced understanding of its involvement in those disparate practices. The critics who championed the Gothic in the seventies and eighties felt they had to validate their enquiry, so argued for the Gothic's worth and interest as literature, together with that notion's often highbrow connotations, even though Gothic texts are frequently tasteless, populist, and even trashy. Although Gothic criticism often distinguishes between 'highbrow' and 'lowbrow' texts, as Lawrence W. Levine has suggested, at least in the American milieu, notions of 'popular' or 'lowbrow' culture cannot wholly treat the way in which some fields are organised. $^{140}$

By describing the Gothic as a discrete practice, we no longer have to argue for its literary worth; or its worth as cinema, music, or so forth. The Gothic text is not always literature, but that is not necessarily a value judgement. A text might be valued

\footnotetext{
${ }^{138}$ Randal Johnson, Introduction, "Pierre Bourdieu on Art, Literature and Culture," The Field of Cultural Production: Essays on Art and Literature, ed. Randal Johnson (New York: Columbia UP, 1993) 20.

${ }^{139}$ Bourdieu, "Outline of a Sociological Theory of Art Perception" 216.

${ }^{140}$ Lawrence W. Levine, Highbrow/Lowbrow: The Emergence of Cultural Hierarchy in America (Cambridge, MA: Harvard UP, 1988) 30-1, 36.
} 
as 'literary', and it might be valued as 'Gothic'; that a text is valued as one does not preclude it from being valued as the other, but these assessments are separate things. The obvious demonstration is that Bookers and Pulitzers are awarded to one kind of book, and Stoker awards are given out to another. We expect something different from a Gothic experience than we do from a literary experience.

Indicative of this difference is the manner in which practitioners of the Gothic describe the genre, as opposed to academic critics. Stephen King believes that horror text works on two levels, presenting its audience with the 'gross-out' and the only slightly more sophisticated tapping of their 'phobic pressure points' ${ }^{141}$ Similarly, Lovecraft's essay, 'Supernatural Horror in Literature', outlines his vision of the 'weird tradition', a term he uses in the same inclusive, transhistorical way that modern criticism uses 'Gothic'. His thesis is that 'the one test of the really weird is simply this - whether or not there be excited in the reader a profound sense of dread, and of contact with unknown spheres and powers'. ${ }^{142}$ Both authors suggest the Gothic is a practice that relates to affect and sensation, locating the phenomenon as much in readers as in texts. While we expect academic and popular discourses to differ substantially, what is striking about these approaches is just how distant they are from some of the ideas that emerge from Gothic criticism, which sees the genre as thoughtful and discursive.

Dracula is an interesting case. Gelder notes the critical consensus in the nineties that the destruction of the vampire Lucy is a revolting act, leading us to think of the Crew of Light as villainous and misogynistic. ${ }^{143}$ Similarly, Anne Williams' reading of Lucy's dispatch fails to engage with any notion that Lucy has become a qualitatively different order of being, a vampire; she is read as a woman, only human, brutalized by men. ${ }^{144}$ For Williams, the Count himself became a 'Mother Goddess'

\footnotetext{
${ }^{141}$ Stephen King, Danse Macabre (London: Futura, 1982).

${ }^{142}$ H.P. Lovecraft, "Supernatural Horror in Literature," The H.P. Lovecraft Omnibus 2: Dagon and Other Macabre Tales (London: Grafton, 1985) 427.

${ }^{143}$ Gelder 76-7.

${ }^{144}$ Williams, Art of Darkness 124-7.
} 
figure, ${ }^{145}$ and thus, in terms of her argument, heroic. Perhaps these are fair rereadings, and meaningfully discursive, but happen to coincide with the rising popularity of Anne Rice's Vampire Chronicles, which place the vampire in the role of protagonist rather than monster, transforming it from an agent of the devil into a Byronic hero. Rice's vampires are more recognisably human and heroic than Stoker's Count. Gothic criticism of historical texts sometimes risks failing to unpick itself from its own contemporary Gothic habitus, from the Gothic as it appears now. At the same time, this confirms Bourdieu's claim that 'so long as there is a generative habitus somewhere at work, one will never cease to "discover" new data' ${ }^{146}$ While Gothic criticism fails to account for the importance of Gothic habitus in the readings produced by a text's intended audience, it also remains blind to the force of contemporary habitus acting upon it. A further possibility here is that the force of critical discourse can enter the field itself, thus contributing to its ongoing rearrangement. It is important to distinguish between scholarly, 'authentic' readings, and critical readings based in a more current Gothic habitus that seek, for whatever reason, to intervene in a popular practice.

At the same time, Gothic criticism privileges the earliest Gothic texts as foundational to the field. Habitus, however, gives disproportionate weight to early past experiences. ${ }^{147}$ For most consumers of the Gothic, their earliest experiences of the genre will have had little to do with eighteenth century texts, but instead come from their own reading and viewing experiences, and thus are most likely to emphasise popular Gothics of the day.

Because Gothic practice is different to literary practice, it offers a different mode of experience for its participants, a type of pleasure that, while present in more generalised literary production, remains very recognisable. Mikita Brottman celebrates

the intoxicating moment... when I learned that books could take you to horrible places - horrible, that is, in a thrilling way: places

\footnotetext{
${ }^{145}$ Williams, Art of Darkness 134.

${ }^{146}$ Bourdieu, Logic of Practice 9.

${ }^{147}$ Bourdieu, Logic of Practice 54.
} 
on the other side of the looking glass where unimaginable nightmares came true, where little girls like me were kept in cages, had their heads chopped off, were cooked and eaten for breakfast... The nastier the stories, the more I liked them. ${ }^{148}$

Christopher Lee, star of many of the Hammer horrors, makes a similar point introducing a collection of macabre tales:

You will note that I have carefully avoided describing the work of [Wheatley, Bloch and Bradbury, amongst others] as 'horror' stories, for this is a term I dislike, just as I dislike it being applied to the kind of films I make. My very good friend, the late Boris Karloff, was similarly opposed to the word, as we both felt we were out to excite and thrill our audiences pleasurably, not horrify them. There is too much horror in the world for us to need to reenact it on the screen. ${ }^{149}$

Both Brottman, a consumer, and Lee, a producer of the Gothic, insist that the Gothic is thrilling and pleasurable, explicitly disconnecting it from the real. These are relatively recent responses to the Gothic text; but there is no doubt that Northanger Abbey's Catherine Morland enjoyed Radcliffe. Indeed, Henry Tilney read Udolpho in two days with his hair standing on end, but describes this as the pleasure of a good novel. ${ }^{150}$ The Gothic is a practice meant to bring about a certain kind of delight. Gothic studies fails to address the gulf between participants' reports of Gothic experience and its own rhetoric, stressing the genre's ability to plumb the horrifying depths of human experience rather than the enjoyment described here.

There is an enormous difference between the experience Gothic readers report and the reading experience we might expect given the frightful and traumatic material

\footnotetext{
${ }^{148}$ Mikita Brottman, The Solitary Vice: Against Reading (Berkley: Counterpoint, 2008) 24.

${ }^{149}$ Christopher Lee, Introduction, Christopher Lee's New Chamber of Horrors, ed. Peter Haining (London: Souvenir Press, 1974) 11-2.

${ }^{150}$ Austen 102-3.
} 
represented in Gothic texts. Where literature promotes serious, discursive engagement with its subject, the Gothic typically encourages a playful approach.

Johan Huizinga's articulation of play remains useful. Play is 'present everywhere as a well-defined quality of action that is different from "ordinary" life. ${ }^{151}$ It 'is "played out" within certain limits of time and place. ${ }^{, 152}$ Play itself is not serious, but it can be performed very seriously. Play 'lies outside the antithesis of wisdom and folly, and equally outside those of truth and falsehood, good and evil.... The valuations of vice and virtue do not apply here. ${ }^{153}$ If we accept Huizinga's claim, we can see how the Gothic and other playful genres present an unusually slippery aspect for modes of criticism that seek to link text to the 'real' of history and psychology. Huizinga describes ancient poetry as being a play-function, but notably excludes modern literature from his argument, suggesting that the play of language in contemporary poetry is less accessible than it is in older literary forms; ${ }^{154}$ his Homo Ludens appeared soon after the zenith of elitist, modernist cultural production, at a time where literature was seen as more serious than playful, a perception which, to some extent, persists today.

We read both Gothic and literary texts for pleasure, but the pleasures on offer are distinct. The individual reader may find more value and pleasure in a text's Gothicness than its literariness. In terms of the original Gothic, a reader like Catherine Morland suggests this. Today, we identify these readers as 'fans', and they happily devour and endorse both literary and subliterary texts so long as they provide the opportunity to play out a satisfyingly Gothic experience.

Brian Sutton-Smith discusses the various meanings held by play. ${ }^{155}$ Play can be imaginative, which is generally feted as creative and improvisational but can become phantasmagoric, deluding, and irrational. This potential is a constant theme

\footnotetext{
${ }^{151}$ J. Huizinga, Homo Ludens: A Study of the Play-Element in Culture, International Library of Sociology, ed. John Rex (London: Routledge \& Kegan Paul, 1949) 4.

152 Huizinga 9.

${ }^{153}$ Huizinga 6.

${ }^{154}$ Huizinga 119-20, 134-5.

${ }^{155}$ Sutton-Smith, The Ambiguity of Play (Cambridge, MA: Harvard UP, 1997) 9-11.
} 
for the Gothic, which, while generally a safe form of play, gestures towards derangement. Play can also involve competitive qualities, and 'genre' fictions frequently have playfully agonistic elements. Detective fiction demands that we pit our wits against the narrative to see if we can work out whodunit before the detective. Likewise, Gothic texts frequently promise to overwhelm us, horror cinema tries to make us hide our eyes; yet often enough, we discover that our nerves are indeed steely enough to consume the text without lasting adverse effect or to keep watching. We imagine that we pit ourselves against the text. Readers likely to be truly disturbed by consuming Gothic texts tend to simply avoid them, opting out of the game. The Gothic reading experience encompasses playful pleasure.

Victor Nell has examined the experience of reading for pleasure with surprising scientific rigour. Nell found that common readers generally understand 'ludic reading' as a form of escapism, and that there is substantial alteration in a reader's consciousness when they read for pleasure. Ludic readers read to achieve a state of absorbed interest, or even 'reading trance' before they read to experience a form of discourse. In this way, the Gothic may tend towards the escapist, but it is escapism of a specific, familiar sort. The experience of reading is more important than the meanings it produces in any conventional sense. One of the curious consequences of this is that 'difficult' texts tend not to work especially well as an aid to achieving an absorbed experience; stereotype, cliché and less complex prose are not necessarily viewed as a problem by the ludic reader, but instead apparently enable the rapid, potentially entrancing reading experience sought. ${ }^{156}$

Nell's work holds provocative implications for literary studies in general, but is especially relevant to criticism of popular literature. How are we to understand texts that appeal through the experience they offer as much as through the interpretive opportunity they provide? Criticism ought to do more than merely interpret Gothic texts, and should address the Gothic experience itself. This approach to Gothic experience might suggest Sontag's famous declaration: 'In place of a hermeneutics we need an erotics of art', ${ }^{157}$ together with all its unresolved difficulty and

\footnotetext{
${ }^{156}$ Victor Nell, Lost in a Book: The Psychology of Reading for Pleasure (New Haven Yale UP, 1988).

157 Susan Sontag, "Against Interpretation," A Susan Sontag Reader (New York: Farrar, Straus and Giroux, 1982) 104.
} 
provocation. The pleasures on offer in the Gothic text differ from the pleasures of literature, and are not to the taste of some readers, although how we are to usefully articulate these differences remains critically troubling.

The corollary of habitus, the 'field', presents a way of understanding how participants organise the texts they are consuming. The act of publication creates an artefact that takes a position in the 'Gothic field', the space in which the Gothic 'game' is played out. The field is 'a patterned system of objective forces (much in the manner of a magnetic field), a relational configuration endowed with a specific gravity which it imposes on all the objects and agents which enter into it. ${ }^{, 58}$ Field relates to Jauss' horizon of expectations, being a

space of possibles, which transcends individual agents, [and] functions as a kind of system of common reference which causes contemporary directors [that is, producers of 'art'], even when they do not consciously refer to each other, to be objectively situated in relation to the others... [part] of the same system of intellectual coordinates and points of reference., 159

Over time, the position of authors and text may shift, erode, expand their influence or be forgotten. Texts relate not just to other texts, but also to other positions in the field. Bourdieu suggests the phrase " a feel for the game"... gives a fairly accurate idea of the almost miraculous encounter between the habitus and a field'. ${ }^{160}$ Individual readers and producers will find their own trajectory through the field over time, and each individual will have a strategy or orientation towards it. ${ }^{161}$

\footnotetext{
${ }^{158}$ Bourdieu and Wacquant 17.

${ }^{159}$ Pierre Bourdieu, "Principles for a Sociology of Cultural Works," trans. Priscilla Parkhurst Ferguson, The Field of Cultural Production: Essays on Art and Literature, ed. Randal Johnson (New York: Columbia UP, 1993) 176-7.

${ }^{160}$ Bourdieu, Logic of Practice 66.

${ }^{161}$ Johnson, "Pierre Bourdieu on Art, Literature and Culture" 17-8.
} 
Texts, through readers' attribution and reattribution of value to them, continue to shape the field, although they will shape the field differently at different times. As Gelder observes, 'To read [Dracula] is to consume the object itself, Dracula, and, at the same time, to produce new knowledges, interpretations, different Draculas. ${ }^{, 162}$ If the Gothic is a popular practice, then this continual reproduction and revaluation is a traceable, historicised process we can see occurring around texts within the field, especially texts that prove to have a durable presence. Common readers, horror fans, writers, publishers, librarians, booksellers, reviewers and academics all contribute to the ongoing and contested allocation of cultural capitals and knowledges to Gothic texts, and it is this which forms the Gothic field. Other fields, including the literary, overlap with the Gothic field but each retains a degree of autonomy. A demonstration of the separation and overlap of the Gothic and literary fields might be seen in the ongoing contestation of Poe's position, a writer whose texts tend to be valued in very different ways, often at the same time. These fields, changeable over time, responsive both to internal changes and also the shifting influence of other intersecting fields, form another important context in which to understand Gothic texts.

The notion of a Gothic field, contained within but distinct from the wider field of power, the field of the historic real that includes all others, reminds us that the Gothic does not relate directly to the world of the real. Bourdieu claims:

The important fact, for the interpretation of works, is that this autonomous social universe functions somewhat like a prism which refracts every external determination: demographic, economic or political events are always retranslated according to the specific logic of the field, and it is by this intermediary that they act on the logic of the development of works. ${ }^{163}$

\footnotetext{
162 Gelder 65.

${ }^{163}$ Pierre Bourdieu, "Field of Power, Literary Field and Habitus," trans. Claud DuVerlie, The Field of Cultural Production: Essays on Art and Literature, ed. Randal Johnson (New York: Columbia UP,
} 1993) 164. 
Practices cannot be 'deduced' either from present conditions that may have provoked them or from past conditions that may have configured the habitus, but instead from the interrelationship of the two. ${ }^{164}$

A historicised understanding of the Gothic field allows us to rediscover the newness that was once attached to certain texts. While Hammer films and The Exorcist coexisted and both claim a Gothic status, the latter must have seemed really new to audiences whose idea of horror involved Christopher Lee in a cape. Reagan's exorcism was shocking not just because of her abjection as an appealingly monstrous yet vulnerable moppet, ${ }^{165}$ but because the story represented another 'turn of the screw'. When we study a Gothic text, we ought to understand the way the Gothic was authored and read, the way the Gothic was performed within that text's originary field. The positioning of texts within fields represents more than simple intertextuality or historicisation; while it acknowledges that sometimes one text relates specifically to another text, or obviously engages in contemporary discourse, a text can relate to a more general way of doing and understanding textual things.

One of the methodological problems the study of the Gothic presents is that the sheer mass of cultural production that involves the genre, even within a focussed timeframe, will exceed the ability of any researcher to explore in total. Choosing to treat one group of texts over another will shape our understanding of the Gothic, yet it simply is not possible or even useful to read every single Gothic text produced at a given moment. The chapters that follow sketch three separate fields, or, as I will argue, two fields and a group of texts which ought to constitute a field, but have not quite succeeded in doing so. They do not attempt to define canons, but instead to survey some of the qualities of the fields. For each area sketched, I am sure there is another view, another version, available. Nevertheless I have tried to show how texts lie in relation to one another, identifying those which lie at the centre of the field and those which are outliers, noting those texts that extend beyond the Gothic field and those that are more uncomplicatedly Gothic. Derrida suggests that

\footnotetext{
${ }^{164}$ Bourdieu, Logic of Practice 56.

${ }^{165}$ Barbara Creed, The Monstrous Feminine: Film, Feminism, Psychoanalysis (London: Routledge, 1993) 31-42.
} 
By orientating and organizing the coherence of the system, the center of a structure permits the play of its elements inside the total form... the center also closes off the play which it opens up and makes possible. As center, it is the point at which the substitution of contents, elements or terms is no longer possible. At the center, the permutation or the transmutation of elements... is forbidden. ${ }^{166}$

Of course, although Derrida does not treat the notion here, the centre itself might alter over time. Some texts will be central to the Gothic at a given moment and embody its core values; others are less central and display variant performances of the genre. All, however, take positions in the field as a condition of being understood as Gothics, and this is what the following chapters demonstrate.

If we wish to reconstruct a contemporaneous reading of a text, we ought to acknowledge that our own Gothic habitus influences our reading, and attempt to assemble a sense of the Gothic as it was performed within that text's originary field. The following chapters explore the potentials of this methodology across three 'moments' within the twentieth century Gothic. Any of the chapters could have been more substantially developed as a history; however, they are presented as case studies, necessarily brief. The primary aim of the thesis remains an investigation of a possible theorisation of the genre and the suggestion of a consequent methodology.

There is no shortage of critical work on the American Gothic of the nineteeneighties, but this has generally insisted that the work is literary and discursive, missing its cruder elements. Chapter two asks how the Gothic relates to literature in the valorised sense. It uses the American field to stage a discussion of the intersection and convergence of literary and Gothic fields, and to suggest the ways that critical theorisations of the genre can enter the field itself.

The English Gothic of the nineteen-sixties provides an opportunity to examine the genre's playful and ritualistic aspects. There is very little critical work that attempts to describe this moment in the English field, which is curious, given its

\footnotetext{
${ }^{166}$ Jacques Derrida, Writing and Difference, trans. Alan Bass (Chicago: U of Chicago P, 1978) 279.
} 
proximity to the beginnings of Gothic studies. Chapter three suggests a particular relationship that exists between Gothic texts and their readers.

The final chapter, a consideration of the New Zealand Gothic, explores how the practice of genre relates to place and national literature. It takes in a longer historical period, from the nineteen-thirties through the nineteen-nineties. There has been only a little work on this field, and what has been done displays problems typical of Gothic criticism. This chapter uses the notion of the New Zealand Gothic to discuss how genres relate to New Zealand literature in particular.

By examining the Gothic as it manifests at different times and in different places, I hope to test the usefulness of the approach to the genre proposed here. I am aware that there is a certain irony in rejecting the usual theorised readings of the Gothic on the basis that they do not engage with the genre as it is popularly practised, only to re-theorise the genre in another way. Nevertheless, enough has been written about the Gothic in the grave language of trauma, psychic rift, epistemological distress and so forth. This thesis aligns itself with Botting's contention that 'Gothic fiction, despite the efforts of its critics, does not lie outside polite, rational and moral culture', ${ }^{167}$ and attempts to show exactly how it lies within the bounds of our culture.

\footnotetext{
${ }^{167}$ Fred Botting, "The Gothic Production of the Unconscious," Spectral Readings: Towards a Gothic Geography, eds. Glennis Byron and David Punter (Basingstoke: Palgrave Macmillan, 1999) 28.
} 


\section{Chapter Two:}

\section{Discourse and Practice in the American Gothic of the Nineteen-Eighties}

Stephen King's story 'The Raft' first appeared in the pornographic magazine Gallery, before it was republished in his 1985 collection of short fictions, Skeleton Crew. It narrates the story of Randy, Deke, Rachel and LaVerne, four university students who swim out to a raft anchored fifty yards from the shore of the secluded Cascade Lake. Deke and Randy are close friends, Deke an athletics star and Randy in pre-med. We do not learn what Rachel and LaVerne are studying, only that Rachel is a blonde, nervy city girl, and La Verne is a brunette. In any case, these details are incidental. The narrative is not really interested in representing people, but in destroying them; unluckily for the friends, the lake is menaced by an amorphous, hypnotising black blob that devours them, one by one.

Rachel dies first. Deke is next, gruesomely pulled between the planks of the raft and consumed. LaVerne and Randy remain, scared and cold as night falls. Huddling for warmth, the pair begin to have sex, but alas, the thing envelops LaVerne's hair which hangs down in the water and consumes her. Randy is left alone and hopeless for a day before he throws himself to the monster.

King's narrative is interested in describing unusual mutilations of the human body. Deke virtually explodes as he is sucked through the half-inch gap in the raft's planks:

Blood was pouring from Deke's eyes, coming with such force that they had bugged out almost comically with the force of the haemorrhage... Blood streamed from both of Deke's ears. His face was a hideous purple turnip, swelled shapeless with the hydrostatic pressure of some unbelievable reversal...

\footnotetext{
${ }^{1}$ Stephen King, "The Raft," Skeleton Crew (1985; London: Futura, 1986) 307.
} 
As Deke dies, we learn he 'voided a great jet of blood, so thick it was almost solid., ${ }^{2}$ LaVerne is reduced to an abject state as she is covered in the blood that shoots out of Deke. “"Oooog!" she cried, her face twisted in half-mad revulsion. "Oooog! Blood! Ooooog, blood! Blood!' She rubbed at herself and only succeeded in smearing it around. ${ }^{3}$ Once Rachel is caught in the blob, her arm is reduced to something that 'looked a little like a rolled roast of beef.'

How should we interpret a story like this? Tony Magistrale believes one of King's major themes is the betrayal of innocence, the fall from grace, and argues this is a useful frame in which to read 'The Raft'. Magistrale's reading makes the blob primarily a metaphor for a youthful fear of adulthood. He believes that:

In its ambiguity and destructive hunger, the dark circle (reminiscent of the spiral imagery in Pet Sematary) becomes a symbol of the mystery of adulthood - capable of mesmerizing at the same time as it plunders - and Randy in particular gains acute insight into this realm before he perishes. ${ }^{5}$

The narrative is accorded value because it seems to say something about what it is to be a young person, and offers us 'insight'. 'The Raft' becomes a coming-of-age story. Heidi Strengell suggests another reason; when Randy tells the monster to 'go to California and find a Roger Corman movie to audition for', this apparently gives 'postmodern substance to the validated nightmare cliché. ${ }^{6}$ In this reading, the tale's engagement with the intellectual zeitgeist is reason enough to examine it. In another reading, Linda Badley notes that King changes to using capitalised letters to denote

\footnotetext{
${ }^{2}$ King, "The Raft" 307.

${ }^{3}$ King, "The Raft" 307.

${ }^{4}$ King, "The Raft" 298.

${ }^{5}$ Tony Magistrale, Landscape of Fear: Stephen King's American Gothic (Madison: The Popular Press, 1988) 84.

${ }^{6}$ King, "The Raft" 317; Heidi Strengell, Dissecting Stephen King: From the Gothic to Literary

Naturalism (Madison: U of Wisconsin P, 2005) 21.
} 
that Rachel is screaming while she is eaten by the blob; 'Help it hurts please help it hurts IT HURTS IT HURRRRR- ${ }^{7}$ Badley argues that 'King reclaims the discounted or discredited language of the body, especially the body in pain., 8

'Insight', 'postmodern substance', and the reclamation of discredited languages are all appropriate reasons to praise or defend a work of literature. However, none of these readings manages to discuss the most immediately obvious elements of the narrative, namely that it is primarily an explicitly sadistic and sexualised depiction of the death of four young people. Magistrale privileges an allegorical reading over a simply representational one, completely avoiding the tale's matter. Strengell takes a throwaway joke and uses it to attach the weight of discourse to the text. Badley, at least, addresses the substance of the narrative, but avoids the obvious point that this spectacular mutilation is written to be relished rather than abhorred. By finding qualities we expect to find in literary fiction in this genre exercise, these critics, while attempting to champion King, become mere apologists, entirely evading what the text is about.

This particular set of readings rehearses one of the problems endemic in critical writing about the Gothic; by treating the genre text as if it were no different to 'serious' literature, a misgauging occurs. These readings avoid the guts of the matter, as it were, misunderstanding not only the function of the story, but the style in which it represents its characters. Often, readers fear for the characters that inhabit Gothic texts, or more precisely, we fear for them on a fictional basis, so that it is as if we fear for them. However, common as this phenomenon might be, it has never been a rule, and 'The Raft' depends on readers agreeing that seeing the four destroyed is an entertaining proposition. To this end, we are distanced from the characters; they are sketches rather than portraits. Our sense of the characters as substantial, as deeply mimetic, is reduced. Deke is dull, a jock and a philanderer. Randy is well-named, envious of Deke's success with women. Rachel and LaVerne are ciphers, developed in even less depth than the boys. If 'The Raft' were a short story in the literary sense, the sort that Michael Chabon has uncharitably described as the 'contemporary,

\footnotetext{
${ }^{7}$ King, "The Raft" 298.

${ }^{8}$ Linda Badley, "The Sin Eater: Orality, Postliteracy, and the Early Stephen King," Stephen King, ed. Harold Bloom, updated ed., Bloom's Modern Critical Views (New York: Chelsea House, 2007) 112.
} 
quotidian, plotless, moment-of-truth, revelatory story', ${ }^{9}$ this would probably be a failing. Instead, this distance facilitates the staging of the brutalisation of the swimmers. We are unencumbered by the readerly concern we might experience if we were deeply involved with these figures. The story is an entertainment, and the primary pleasure it offers is the spectacular destruction of the unfortunate students.

Given the principle of 'The Raft', it is unsurprising that King's success has afforded critics like Harold Bloom the opportunity to declare the death of the 'Literate Reader'. ${ }^{10}$ This is exactly the assessment that King's advocates resist, and this resistance tends to take the form of simple contradiction. King, they claim, is practising literature. The argument of my first chapter suggests a third way; in 'The Raft', King is performing the Gothic rather than practising literature. The American Gothic of the nineteen eighties included literary as well as semi- or non-literary texts, and King was a key figure in its development.

This chapter examines works by King, Joyce Carol Oates and Toni Morrison in the context of critical engagements with the American Gothic. It briefly describes significant strands within that criticism, before turning to King's It, Oates' Mysteries of Winterthurn and Morrison's Beloved. It provides a useful example of a wildly successful popular Gothic that has little to do with the American Gothic as it is critically described; nevertheless, in a limited and specifically Gothic way, it engages with the postmodern zeitgeist of the eighties. It's success strongly suggests that the Gothic is a discrete practice from literature. However, this argument is complicated by discussions of Winterthurn and Beloved. Oates' and Morrison's texts perform the Gothic as it has been critically rather than popularly described, thus conflating the literary practice with the popular practice of the Gothic. Morrison orchestrates this conflation carefully in Beloved, while it creates substantial difficulties within Winterthurn.

Rather than undermining the argument that the Gothic is a distinct strand within our habitus, separate from our literary practice, the chapter attempts to

\footnotetext{
${ }^{9}$ Michael Chabon, Introduction, "The Editor's Notebook: A Confidential Chat with the Editor," McSweeney's Mammoth Treasury of Thrilling Tales, ed. Michael Chabon (N.p.: Penguin, 2004) 6.

${ }^{10}$ Harold Bloom, Introduction, Stephen King, ed. Harold Bloom, updated ed., Bloom's Modern Critical Views (New York: Chelsea House, 2007) 3.
} 
demonstrate the analytical usefulness of the distinction, while addressing the commingling of the two practices. One of the points emerging from this discussion is that Gothic criticism misrecognises the contemporary Gothic as a natural rather than historically constructed category, and tends to read this back into earlier texts. Similarly, literary engagements with the Gothic can attempt to refashion the practice so that it conforms more closely to the contemporary critical vision. The American Gothic of the eighties is a useful milieu in which to examine this relationship, as it has developed, at least in some ways, conterminously with Gothic studies as a specialist field.

\section{American Gothic Studies and the Field}

The American Gothic has received substantial critical attention since the early eighties. A handful of key critical gestures persist in discussions about it. These include the attempt to posit the Gothic as a major mode of American cultural expression, and an insistence on linking it to the 'real', understanding the genre as an expression of specific historical anxieties. Consequently, attempts are made to relate Gothic texts to the troubled racial history of the States. The Gothic is thought to articulate the 'dark side' of the cultural moment from which it emerges. However, there is little interest in historicising the notion of the Gothic itself. Instead, the genre is represented as vaguely ahistoric, although there is also the critical urge to locate its origins, often with Charles Brockden Brown, with special importance being accorded to the works of Poe and Hawthorne in the nineteenth century.

Foundational texts in Gothic studies by Moers and Gilbert and Gubar were most interested in the British Gothic of the late eighteenth and first half of the nineteenth centuries; Punter's Literature of Terror does, however, include a chapter devoted to the nineteenth century American Gothic. Punter uses the notion of national Gothics to organise much of his discussion in The Literature of Terror, yet when he turns his attention to the Gothic of the latter twentieth century, he abandons this as an organisational method, treating American and other literatures side-by-side. ${ }^{11}$ Perhaps

\footnotetext{
${ }^{11}$ David Punter, The Literature of Terror: A History of Gothic Fictions from 1765 to the Present Day, Digital Print on Demand, 2003 ed., vol. 2, (Harlow: Longman, 1996) 119-44.
} 
this reflects the later twentieth century's globalisation of Western culture; in any case, the notion of a national Gothic encourages criticism to look to history, both of nations, and of the Gothics written within their borders, which tends to create the sense that a national Gothic has 'roots'.

Critical discussions of an American Gothic predate the development of Gothic studies. Justin D. Edwards locates this within Leslie Fiedler's 1960 Love and Death in the American Novel, which Edwards believes 'revolutionised' the study of the Gothic and was the first to argue for a truly separate American Gothic tradition. ${ }^{12}$ This attribution relates to Edwards' definition of the Gothic, but it is debatable. Harlan Hatcher, writing in 1934, described what was essentially a thriving contemporary American Gothic, in which he includes the writings of Faulkner, Robinson Jeffers and Sinclair Lewis amongst now-obscure titles. ${ }^{13}$ As noted in chapter one, the Southern Gothic, necessarily native to America, held currency by the early fifties. Nevertheless, if we understand Fiedler's work as addressing the Gothic, it anticipates the later critical interest in finding the Gothic in unexpected places; Fiedler treats Twain's Adventures of Huckleberry Finn as well as Poe.

However, Fiedler's work seldom uses the term 'Gothic', and many of the texts it treats do not substantially participate in the genre. While the Gothic is also often interested in love and death, it is a mistake to treat the genre and these twin themes as substantially similar; this underlines the problems attendant on thematic definitions of the Gothic. Nevertheless, the critical urge to include Fiedler's prestigious work within Gothic studies suggests that Gothic studies is happy to promote the Gothic as being central to American literary discourses.

Donald A. Ringe's 1982 American Gothic believes it is the first monograph to give a 'sustained treatment of [the American Gothic's] development'. ${ }^{14}$ The forthrightness of the claim suggests that Gothic studies as we now have it was beginning to cohere as a field, and specifically that the term 'Gothic' was increasingly

\footnotetext{
${ }^{12}$ Justin D. Edwards, Gothic Passages: Racial Ambiguity and the American Gothic (Iowa City: U of Iowa P, 2003) xvii.

${ }^{13}$ Hatcher 91-3.

${ }^{14}$ Donald A. Ringe, American Gothic: Imagination and Reason in Nineteenth-Century Fiction

(Lexington: UP of Kentucky, 1982) v.
} 
being used to identify the area of enquiry. However, Ringe's interest is limited to the nineteenth century, and his version of the American Gothic is a closed canon, a style that peaked even before 'The Turn of the Screw'. Ringe attributes discursive, literary worth to the nineteenth century texts, concluding that

No one today could express through [the Gothic's] use the broad philosophic themes of Poe or the great moral ones of Hawthorne. The American Gothic reached its peak in their work. After their passing it ceased to play a significant role in major American fiction. ${ }^{15}$

For Ringe, the Gothic had once been a major strand of American cultural production. Harry Levin's monograph on Hawthorne, Melville and Poe had already argued that the 'cherished [American] Renaissance was inspired by European romanticism' and that romanticism, including its predilection for the Gothic turn, sat at the centre of the American canon. ${ }^{16}$ However, Ringe reminds us that American writers like Fenimore Cooper and Hawthorne complained that a genuinely American form of romance, and by extension, the Gothic, was problematic because America was far too workaday, upbeat, and lacked a sufficiently dark past to draw on. ${ }^{17}$

In The Scarlet Letter, this complaint is dramatised in the distinction between the banal Custom-House of the framing narrative and the haunted world of the Puritans. Olden Salem affords a stage on which to enact the Gothic that Hawthorne's present does not. More recent engagements with the American Gothic do not share this concern, and contemporary readers would not understand America's history of Indian massacres, slavery and wars as pedestrian and untroubled. Nevertheless, the distinction between our perception and a nineteenth century understanding is interesting. Hawthorne's present, which failed to afford him the Gothic possibilities

\footnotetext{
${ }^{15}$ Ringe 189.

${ }^{16}$ Harry Levin, The Power of Blackness: Hawthorne, Poe, Melville (New York: Alfred A. Knopf, 1970) 19.

${ }^{17}$ Ringe 1-2.
} 
he required, becomes available for later Gothicists. Both Beloved and Winterthurn have nineteenth century settings.

Ringe argues that the Gothics of Poe and other nineteenth century writers came from a desire to imaginatively throw off the shackles of a rational American tradition. ${ }^{18}$ He links the origins of the American Gothic strongly to the influence of European Gothics, ${ }^{19}$ and in this follows Levin, identifying the Gothic as an imported tradition.

Ringe's assessment is at odds with much of the critical work that has followed, which emphasises continuity between the American Gothic of the nineteenth and twentieth centuries. Mark Edmundson, writing at the end of the twentieth, makes this notion explicit, claiming that 'Poe is lord (if there is a lord) in contemporary culture'; ${ }^{20}$ for Edmundson, the Gothic we have today is Poe's Gothic, and he acknowledges his approach 'shuttles between the late eighteenth and the late twentieth centuries with only a few stopping points between. ${ }^{21}$

The ahistoric nature of this approach is facilitated by criticism that emphasises an organic relationship between the American Gothic and the nation that produced it, so that the very forces that produced the nation also produced the subgenre. This invokes history, while softening its specificity. Alan Lloyd-Smith describes what he believes are the unique conditions which lead to the development of a distinct American Gothic as opposed to earlier British and European Gothics:

Rather than a matter of imitation and adaptation, substituting the wilderness and the city for the subterranean rooms and corridors of the monastery... certain unique cultural pressures led Americans to the Gothic as an expression of their very different conditions.

Among these American pressures were the frontier experience, with its inherent solitude and potential violence; the

\footnotetext{
${ }^{18}$ Ringe 6-7.

${ }^{19}$ Ringe 10.

${ }^{20}$ Edmundson 155 .

${ }^{21}$ Edmundson xvii-xviii.
} 
Puritan inheritance; fear of European subversion and anxieties about popular democracy which was then a new experiment; the relative absence of developed "society"; and very significantly, racial issues concerning both slavery and the Native Americans. ${ }^{22}$

Lloyd-Smith connects the uniqueness of the American Gothic to 'real-world' conditions to account for why it is distinct.

Gothic criticism often discusses how media representations of the real, and the 'real' itself, are involved with the American Gothic. Teresa A Goddu argues that Gothics are not escapist but 'intimately connected with the culture that produces them. ${ }^{23}$ Mark Edmundson and Toni Morrison both insist the American Gothic is linked to 'real' phenomena too. Edmundson describes the Gothic as including the O.J. Simpson trial, the Timothy McVeigh case, and the Unabomber. ${ }^{24}$ Morrison links the Gothic with Puritanism and the sermon, and discusses the Gothic and romance as a 'head-on encounter with the very real, pressing historical forces and the contradictions inherent in them'. 25

Charles Crow neatly summarises what many critics would agree is the function of the American Gothic when he writes that

The Gothic is a literature of opposition. If the national story of the United States has been one of faith in progress and success and in opportunity for the individual, Gothic literature can tell the story of those who are rejected, oppressed, or who have failed. ${ }^{26}$

\footnotetext{
${ }^{22}$ Alan Lloyd-Smith, American Gothic Fiction: An Introduction, Continuum Studies in Literary Genre (New York: Continuum, 2004) 4.

${ }^{23}$ Goddu 2.

${ }^{24}$ Edmundson 12-3.

${ }^{25}$ Toni Morrison, Playing in the Dark: Whiteness and the Literary Imagination (Cambridge, MA: Harvard UP, 1992) 36.

${ }^{26}$ Charles L. Crow, Introduction, American Gothic: An Anthology 1787 - 1916, ed. Charles L. Crow (Malden: Blackwell, 1999) 2.
} 
Like Crow, Goddu favours a definition of the American Gothic which is negative; her definition 'depends less on the particular set of conventions it establishes than on those it disrupts. ${ }^{27}$ She emphasises the especial importance of issues of race and slavery to the American Gothic. Goddu's Gothic is not limited to text since she believes that 'gothic tales are enacted in the everyday terrorism of the Ku Klux Klan and that accounts of those terrors can evoke in the reader a response similar to that provoked by a gothic tale'. ${ }^{28}$

The notion that the American Gothic is intimately involved with racial discourse is also emphasised by Edwards, who argues the genre deals with fears of miscegenation, and is especially interested in undermining any notion of fixed identity. ${ }^{29}$ Edwards purposely treats Gothic fictions and 'the fictive discourses of the human sciences, particularly biology, anthropology, and nineteenth-century theories of heredity and evolution' as being similar. ${ }^{30}$ For Edwards,

gothic discourses are alive and well - not just in Anne Rice's novels and Tim Burton's films - but in media renderings of the September 11, 2001 terrorist attacks, in our political discourse, in our modes of therapy, on TV news, on talk shows such as Oprah... ${ }^{31}$

Edwards' appreciation of the American Gothic is echoed by any number of critics. ${ }^{32}$

\footnotetext{
${ }^{27}$ Goddu 4.

${ }^{28}$ Goddu 2.

${ }^{29}$ Edwards, Gothic Passages xxiii-xxvii.

${ }^{30}$ Edwards, Gothic Passages xi.

${ }^{31}$ Edwards, Gothic Passages xxiii.

${ }^{32}$ For additional instances, see Eric Savoy, "The Face of the Tenant: A Theory of American Gothic," American Gothic: New Interventions in a National Narrative, eds. Robert K. Martin and Eric Savoy (Iowa City: U of Iowa P, 1998); Idiart and Schulz, "American Gothic Landscapes"; Cohen.
} 
In the United States, the sixties and seventies had seen a dearth of magazines publishing the Gothic and, with some exceptions, few major houses were interested in publishing horrifying texts. ${ }^{33}$ For much of the twentieth century, the short tale had been the Gothic's habitual form. However, the mid-seventies saw the advent of the novel-length horror blockbuster with the emergence of King. This marked a new and distinct period. 'Horror', as practiced by King, became a distinct strategy, a discrete sort of fiction within the field. Gothics became a potentially lucrative category for publishers. This led to the development of a substantial 'mid-list' of specialised horror authors. ${ }^{34}$ King's success with longer horror narratives encouraged the new horror writers to produce novel-length works. ${ }^{35}$

The later seventies and early to mid eighties saw the publishing hey-day of horror fiction in both hard and paperback; one informed estimate suggests as much as ten times the amount of horror was published in the early eighties as had been a few years earlier, with many publishers starting separate horror lines. ${ }^{36}$ Fiction that was being marketed as speculative, which includes science fiction and fantasy as well as horror, accounted for ten percent of the novel market in America in the mid-eighties, ${ }^{37}$ and horror was the fastest growing of these categories. ${ }^{38}$ A number of specialist small presses were established, and a rich and probably overpopulated horror magazine market developed, which published tales, novella-length works, and serialized longer

\footnotetext{
${ }^{33}$ Michael A. Morrison, "After the Danse: Horror at the End of the Century," A Dark Night's Dreaming: Contemporary American Horror Fiction, eds. Tony Magistrale and Michael A. Morrison (Columbia: U of South Carolina P, 1996) 19.

${ }^{34}$ Steffen Hantke, "The Decline of the Literary Horror Market in the 1990s and Dell's Abyss Series," The Journal of Popular Culture 41.1 (2008): 57.

${ }^{35}$ Morrison, "After the Danse" 11.

${ }^{36}$ Hantke 56-7.

${ }^{37}$ J.N. Williamson, Foreword, "Certain of What We Do Not See," $\underline{\text { How to Write Tales of Horror, }}$

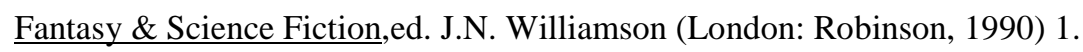

${ }^{38}$ Morrison, "After the Danse" 9.
} 
narratives. ${ }^{39}$ This expansion of the Gothic field is better understood as a popular interest in a particular mode of entertainment rather than an expression of cultural crisis. The growth of the field has little to do with the sorts of values attached to the Gothic by academic criticism.

Andreas Huyssen argues that modernism can be understood as constituting itself by excluding elements of a consuming mass culture, which led to the 'Great Divide' between high culture and low. ${ }^{40}$ While Bourdieu finds this divide, or, at least a real degree of stratification, to be present in early 1980s France, ${ }^{41}$ Huyssen argues that postmodernism, which he locates as an especially American phenomenon, is interested in bringing together mass culture and canonized art. ${ }^{42}$ These two basically irreconcilable views provide a useful framework in which to examine the American Gothic of the eighties, as King, Oates and Morrison practise it. If King can be understood as representative of the 'culture industry', forever excluded from literary canonisation by critics like Bloom, then Oates' cycle of experiments with popular genres is an attempt to bridge Huyssen's divide. Beloved is a more proficiently managed effort to do the same.

Yet for all Huyssen and his successors' careful enthusiasm about the possibilities opened up by postmodernism, he remained basically interested in 'art' as high culture has historically understood it. This is a manoeuvre typical of academic appreciations of popular culture since the eighties, which appear to embrace new sorts of text but refuse to shift their reading strategies to meet them. The end result is that rather than a genuine bridging of a supposed divide, one practice is appropriated in the service of another. This difficulty becomes evident when we compare the way that Oates in particular writes about the Gothic with the way that King and the mid-list authors who followed him do.

\footnotetext{
${ }^{39}$ Morrison, "After the Danse" 19; Janet Fox, "Overview of Horror, SF and Fantasy: A Long-Range Market Study," How to Write Tales of Horror, Fantasy and Science Fiction, ed. J.N. Williamson (London: Robinson, 1990).

${ }^{40}$ Andreas Huyssen, After the Great Divide: Modernism, Mass Culture, Postmodernism (Bloomington and Indianapolis: Indiana UP, 1986) vii.

${ }^{41}$ Bourdieu, Distinction.

${ }^{42}$ Huyssen 188, 194, 197.
} 
Oates has had a substantial career inside the academy, teaching at the Universities of Detroit and Windsor, before moving to Princeton in $1978 .^{43}$ The academic environment she inhabits naturally informs her appreciation of the Gothic. In her article 'Frankenstein's Fallen Angel', which appeared at the time Winterthurn was published, she presents a reading of the Gothic classic, arguing that it is a 'novel sui generis, if a novel at all... a unique blending of Gothic, fabulist, allegorical, and philosophical materials. ${ }^{44}$ She strongly emphasises the literary values of the text, its intertextuality with Paradise Lost, its serious moral engagement with a world beyond good and evil, and claims that

a literary antecedent for Frankenstein... might be, surprisingly, Samuel Johnson's Rasselas, rather than a popular Gothic work like Mrs. Radcliffe's Mysteries of Udolpho, which allegedly had the power to frighten its readers. ${ }^{45}$

Oates situates Shelley's text as high literature, rather than as a popular text. For her, Frankenstein 'contains no characters, only points of view'; ${ }^{46}$ it is a work that offers discourse before it offers mimetic efficacy or affective power.

Like most modern readers, Oates is unlikely to be affrighted by Udolpho; but she expresses scepticism that the text ever held affective power. Regardless of how many readers were genuinely affected by Radcliffe, Oates clearly favours the reflective pleasures of literature rather than affective, immersive experience. She believes Shelley's text 'is meant as prophecy, not to entertain. ${ }^{47}$ Oates underlines her interest in the discursive properties of the Gothic when she attacks Moers' reading of Frankenstein, which 'reduces a complex philosophical narrative to little more than a

\footnotetext{
${ }^{43}$ Greg Johnson, Understanding Joyce Carol Oates, Understanding Contemporary American Literature (Columbia: U of South Carolina P, 1987) 5-6.

${ }^{44}$ Joyce Carol Oates, "Frankenstein’s Fallen Angel," Critical Inquiry 10.3 (1984): 543.

${ }^{45}$ Oates, "Frankenstein's Fallen Angel" 549.

${ }^{46}$ Oates, "Frankenstein's Fallen Angel" 549.

${ }^{47}$ Oates, "Frankenstein's Fallen Angel" 550.
} 
semiconscious fantasy, scarcely a literary work at all. Did Mary Shelley's womb, or her brain, write Frankenstein? ${ }^{48}$ For Oates, the only relevant capital is literary.

Toni Morrison has also articulated the reasons for her interest in the Gothic, considering the American romance in Playing in the Dark. She is especially interested in images of blackness and whiteness as they occur in Hawthorne and Melville, even claiming that 'No early American writer is more important to the concept of American Africanism than Poe. ${ }^{49}$ This interest seems to predict the arguments Goddu and Edwards would develop shortly afterward, linking the darkness of African American skin to the sorts of darkness which have fascinated the Gothic. However, Morrison's project is wider, in that she desires a re-reading of American literature as a whole in the light of the 'Africanist' presence in America. The Gothic is involved in this project, but is not a privileged site within it. However, it seems fair to say that, like Oates, Morrison's approach to the genre is heavily discursive, that both writers tend to look back to the nineteenth century to anchor their considerations of the Gothic, and that both see the Gothic as relating strongly to the real. These notions are developed in both Winterthurn and Beloved.

Morrison's and Oates' claims exist in stark contrast to appreciations of the genre produced by populist writers. The 1987 collection How to Write Tales of Horror, Fantasy \& Science Fiction brings together pieces by a number of established genre authors and editors, framed as advice to aspiring writers. It provides a surprisingly comprehensive statement of the values held by a group of populist practitioners of the contemporary Gothic. Unsurprisingly, the values it attaches to the Gothic, typically described as 'horror' or 'dark fantasy', are very different from the historicising, academically sanctioned traditions Oates and Morrison draw on. This partly reflects a difference in purpose, as How to Write aims to practically instruct, but it also demonstrates real differences in the way that popular writers, and by extension, their fans, conceived of the contemporary Gothic. How to Write stresses the importance of contemporary rather than nineteenth century productions to understanding the field.

Consider William F. Nolan's advice:

\footnotetext{
${ }^{48}$ Oates, "Frankenstein's Fallen Angel" 554 n.5.

${ }^{49}$ Morrison, Playing in the Dark 32.
} 
In the no-TV, no-video, no-comics world of Charles Dickens, readers were conditioned to deal with complex, dense, often-wordy opening pages in books and stories... Not so today... Quick, gaudy images flash across the TV screen to grab our attention. For a short story or novel to compete in this modern world... it must engage the reader's attention instantly. ${ }^{50}$

This approach might not engender texts of lasting literary worth, but it does make the point that Nolan believes the populist author's work has little to do with canonical literature, and instead competes with a variety of modern media. Nolan is suggesting a difference in approach considerably deeper than whether or not a text has a punchy opening or not; although in written form, the Gothic might have nothing to do with literature at all. Conspicuously absent is any claim the genre has a special relationship with the real.

How to Write offers a view of fiction that could not be more different to Oates', in particular. One writer feels that Gothic narrative is primarily affective ('You want to set spines a-shivering, souls a-shaking - and sometimes stomachs aspasming'!), that readers want to be scared, and that what they need is for the text to be 'believable'. ${ }^{51}$ Another feels that the "primary purpose of dark fantasy is to tell a story that will... give the reader a chill, a shiver, a good scare... If that doesn't work... then the story doesn't work'. ${ }^{52}$ This, we should remember, is a quality Oates finds difficult to even postulate in Radcliffe's text. Another contributor casts the tale of terror as a retelling of the 'struggle between good and evil', a contention which is

\footnotetext{
${ }^{50}$ William F. Nolan, "Involving Your Reader from the Start," How to Write Tales of Horror, Fantasy \& Science Fiction, ed. J.N. Williamson (London: Robinson, 1990) 50.

${ }^{51}$ Mort Castle, "Reality and the Waking Nightmare: Setting and Character in Horror Fiction," How to Write Tales of Horror, Fantasy \& Science Fiction, ed. J.N. Williamson (London: Robinson, 1990) 29.

${ }^{52}$ Charles L. Grant, "Stepping into the Shadows," How to Write Tales of Horror, Fantasy \& Science Fiction, ed. J.N. Williamson (London: Robinson, 1990) 64.
} 
the polar opposite of Oates' post-Nietzschean reading of Frankenstein. ${ }^{53}$ The collection's editor worries that 'the expressions serious novel and serious writer' have 'loaded implications' for demotic genre writers, ${ }^{54}$ indicating an anxiety about how genre writers are viewed by the literary establishment.

Where Oates praises the complexity and literary quality of Frankenstein, How to Write's contributors tend to laud 'originality' above all. ${ }^{55}$ But what is this 'originality'? In a form where writers are advised to embrace formulaic techniques, such as always having a gripping opening or carefully embracing the quotidian to maximise its contrast with the monstrous, ${ }^{56}$ how can the advice-givers possibly be demanding actual originality? In fact, originality in this context seems to denote an awareness of the horror field, and the ability to formulate a congruent but distinct strategy, a novel spin on things. The collection's emphasis is overwhelmingly on the contemporary; the one book the aspiring writer of the supernatural must read is apparently Peter Straub's 1979 Ghost Story. ${ }^{57}$ This advice seems very close to a description of the 'game sense' central to the functioning of the Gothic field.

The values espoused in How to Write are not the same as those that King puts forward in his substantial study of the field, Danse Macabre, but they are similar. King argues that game-sense is important to understanding the Gothic field; he believes that fans develop a degree of sophistication when they continue to engage with horror texts, 'a feeling for the depth and texture of the genre'. ${ }^{58}$ If this were high

\footnotetext{
${ }^{53}$ Robert R. McCammon, "Innocence and Terror - The Heart of Horror," How to Write Tales of Horror, Fantasy \& Science Fiction, ed. J.N. Williamson (London: Robinson, 1990) 67.
}

${ }^{54}$ J.N. Williamson, "Plotting as Your Power Source," How to Write Tales of Horror, Fantasy \& Science Fiction, ed. J.N. Williamson (London: Robinson, 1990) 26.

${ }^{55}$ See, amongst others; Robert Bloch, "Introduction: How to Write Horribly for Fun and Profit," 9; James Kisner, "Freedom of Originality in Fantastic Fiction - and How to Use It"; Ramsey Campbell, "Avoiding What's Been Done to Death"; all in How to Write Tales of Horror, Fantasy \& Science Fiction, ed. J.N. Williamson (London: Robinson, 1990).

\footnotetext{
${ }^{56}$ Nolan; Castle 30.

${ }^{57}$ Kisner 52-3.

${ }^{58}$ King, Danse Macabre 167. See also 40, 42, 48 for instances where King discusses the value of something like a game-sense in understanding the horror field.
} 
culture being discussed, we would think of this as the formation of a genuine individual taste and aesthetic competence. King is well aware that horror readers are not indiscriminate consumers of grue, and acknowledges most of the horror writing produced at the height of the horror boom was 'downright bad' ${ }^{59}$ However, he also believes that a discrete knowledge, or, in the terms used by this thesis, habitus, is required to understand the genre, expressing frustration that when mainstream film reviewers engage with horror films, they 'don't know what they are seeing., 60

Unlike How to Write, Danse Macabre discusses older, 'classic' Gothic texts in addition to contemporary ones. King is engaged not just with the contemporary state of the field, but also with how it achieved that state. King also devotes a substantial part of his discussion to horror film, suggesting that he sees the Gothic as a practice that reaches easily into other media; literature, on the other hand, cannot do this without potentially undermining its literariness.

King tends to resist allegorical readings of horror, arguing that sometimes meanings are not the most important thing in a text, asking, 'to simply delight the reader is enough, isn't it?' ${ }^{61}$ While King makes his argument lightly, its implications are substantial; he does not deny the importance of reflective, thoughtful, meaningful reading, but suggests the primary mode in which horror readers and writers operate is more concerned with immediately pleasing the reader. When critics like Bloom complain that King's writing is not of literary quality, they perpetrate a category error, as King is not aiming for literary quality in tales like 'The Raft'. As King himself reflects, in relation to another of his simple gross-out narratives, the autophagous shocker 'Survivor Type', 'I guess Faulkner never would have written anything like this, huh? Oh, well. ${ }^{62}$

This confusion of purpose is one that even King's advocates promote. Strengell writes in the conclusion of her monograph on King, 'Indeed, the horror genre has always been plagued by its fascination with the grotesque... I have

\footnotetext{
${ }^{59}$ King, Danse Macabre 282.

${ }^{60}$ King, Danse Macabre 247.

${ }^{61}$ King, Danse Macabre 20, 29.

${ }^{62}$ King, Notes, Skeleton Crew (1985; London: Futura, 1986) 611.
} 
attempted to show more reasons for King's popularity than the visceral. ${ }^{63}$ Aside from the perplexing suggestion that grotesquery plagues horror, a concern that amounts to a feeling that horror might be horrible, Strengell's tone is apologetic, as if the only way to accord value to King is to demonstrate that his work is, at heart, literary. King's defenders tend to argue that what is good about his texts is good despite the fact that he often writes horror. What if a substantial part of King's value is that he is good at writing horrors?

\section{It}

Skeleton Crew, in which 'The Raft' appears, was, according to the New York Times, the seventh bestselling work of paperback fiction in American in 1986, a remarkable achievement given it is a collection of short stories. More significant, however, is It, which was the bestselling work of hardcover fiction that year. ${ }^{64}$ Popular interest in King was such that It's release garnered King the cover of Time magazine, while the book itself went through six printings in less than a year, with more than a million copies in circulation. This is remarkable; It is a long book - my edition is 1116 tightly set pages, printed on the kind of stock generally reserved for paperback Bibles - and even by King's own admission, is 'very badly constructed' ${ }^{65}$ It does not have the coherence of Pet Sematary, and does not manage the suspense of Misery. Indeed, It's horrors are crude, and its narrative sometimes laboured.

Regardless of whether It represents the best of King, it became something of a phenomenon. In addition to capturing the popular imagination, It is one of the very few King books reviewed in the vaunted New York Review of Books. Reviewer Thomas R. Edwards is positive; 'It seems almost serious when compared with a "respectable" adult best seller like James Clavell's Whirlwind' ${ }^{66}$ Edwards'

\footnotetext{
${ }^{63}$ Strengell 264.

${ }^{64}$ Edwin McDowell, "'Fatherhood' and 'It' Top Sellers of '86," New York Times January 51987.

${ }^{65}$ Stefan Kanfer, "King of Horror," Time October 61986.

${ }^{66}$ Thomas R. Edwards, "Gulp!" rev. of It by Stephen King and Whirlwind by James Clavell, The New York Review of Books 18 Dec. 1986: 58-60.
} 
comparative reading reminds us that King is a special case, rather than a good instance of a bestselling author. Where Edwards finds Clavell basically execrable, he discusses King in explicitly literary terms; he admits that King 'is not quite a “serious" writer' but describes him as 'neo-Wordsworthian' and discusses King's constructions of childhood, adulthood and power. Yet, as much as Edwards understands the text as participating in literature and discourse, It speaks more eloquently to the Gothic field than it does to the literary.

It's narrative straddles two periods, the late fifties and the mid-eighties, relating the struggle of a group of school friends, the 'Losers Club', against the monstrous It. Every twenty-seven years, It attacks the people of Derry, especially the children, a pattern of violence that concludes in some catastrophe that kills many. Derry is under It's spell, somehow forgetting or ignoring what happens under It's sinister influence. Each of the Losers is marked out by some difference that sets them apart from their peers and encourages the town's bullies to attack them when they are young. Bill had a stutter and lost his brother to It in 1957; Stan is Jewish and kills himself rather than return to face the monster; Beverley is abused by her father and later, her partner; Eddie is a hypochondriac; Ben was fat; Mike is the town's only African American, and Richie is at first a socially awkward wise guy. The twinned narratives begin to alternate rapidly as It reaches its climax with the Losers battling It in the sewers of Derry in both the present and the past.

There are many ways in which we can see It as discursively involved in contemporary, real-world fears. In the seventies and eighties, a range of perceived domestic threats, especially to young people and women, replaced the Red Scare of the early fifties. Cults, networks of pederasts, Satanists and serial killers were thought to be 'out there' in America. Philip Jenkins notes Reagan's America frequently espoused 'a florid imagery of dangerous, conspiratorial outsiders [that] became thoroughly integrated into political rhetoric... permeated by themes of external threat, national vulnerability, subversion, and internal decadence. ${ }^{67}$ The monster It is alien but entirely integrated into Derry, the ultimate insider and outsider simultaneously, representing an especial threat to children.

\footnotetext{
${ }^{67}$ Philip Jenkins, Decade of Nightmares: The End of the Sixties and the Making of Eighties America (New York: Oxford UP, 2006) 11.
} 
The cult of the serial killer developed throughout the later seventies. There was nothing new in serial killing, but the notion of the serial killer we now possess developed as the crimes of Ted Bundy and John Wayne Gacy came to light, and serial murder began to be regarded as a serious threat by many Americans. ${ }^{68}$ Gacy, notorious for molesting and killing a large number of boys and young men, and for occasionally hosting parties dressed as a clown named 'Pogo', is an especially salient figure for $I t$, where the monster, which takes many forms, most often appears as Pennywise the clown. It operates much like the popular conception of a serial killer, the stranger who lures children away to their deaths.

Despite popular concerns about cults and killers, this kind of violence remained extraordinary in America. However, It depicts violence of a more familiar sort too. Henry Bowers and his friends, who bully the Losers in 1958, appear to be It's agents; but they are also the epitome of the new breed of young criminal that Jenkins argues eighties America feared, far more violent than anything it had seen before. ${ }^{69}$ This might be a reiteration of fifties anxieties about juvenile delinquents, but it is an anxiety that had recently been renewed at the time of It's publication. Jenkins also argues that in the late seventies and early eighties, the physical and sexual abuse of women was recognised through the efforts of feminist activism, but that many claims massively exaggerated the extent of abuse so that the family became figured as a site of epidemic patriarchal violence. ${ }^{70} I t$ features extended presentations of Beverley's abuse at the hands of her father and her husband.

Repressed memory theory was current in popular discourse. Believers thought traumatic memories might be effectively forgotten and then recovered, a claim that led to bizarre allegations being made by 'survivors' and nonexistent crimes being confessed to. ${ }^{71}$ The Losers have largely repressed their earlier traumatic experience of It, and the narrative is arranged so that it depicts their process of remembering. Only

\footnotetext{
68 Jenkins 143.

${ }^{69}$ Jenkins 137. See also Ed Magnuson, "The Curse of Violent Crime," Time Mar. 23 1981: 16-30.

${ }^{70}$ Jenkins 117.

${ }^{71}$ Frankfurter.
} 
as they enter the sewer in the eighties do the friends begin to recall what happened beneath Derry in the fifties.

These links between the text and the real might endorse academic modes of reading, where the Gothic provides a discursive space in which to explore dangerous, repressed subjects. Regardless of King's stated resistance to using Gothic texts as allegories, It does fulfil a partly allegorical role, becoming a symbol that accumulates meanings; It is hate, fear, sex, madness, an accelerant for homophobic and racist hate crimes. At the same time, It is a killer clown, a giant spider, a monstrous eye. While It takes many forms, they do not quite discursively cohere; what, really, have all these things to do with one another? Examined individually, any of these points might suggest that It is interested in examining 'real world' fears. Taken together, and given that they are ideas that are only presented rather than substantively explored in the text, they suggest that $I t$ is using real world fears to another end. It is a book about It before it is about any of these individual discourses. This rejection of discursivity is enacted in $I t$, when Mike, the African American Loser, drunkenly mocks a sophisticated New York woman who enquires 'if anyone in Derry understood THE BLACK EXPERIENCE. ${ }^{72}$

This is typical of King's approach. The Dead Zone hinges on political assassination, but is not really about political assassination. Terrible things emerge from the Native American burial ground in Pet Sematary, but it is more concerned with the menace of a zombie cat than the enactment of postcolonial anxieties. King believes horror texts search for 'phobic pressure points', but his discussion stresses that the purpose of exerting pressure on these points is the generation of affect. Horror is meant to give us 'the creeps' before it explores why we might have a particular phobic reaction. ${ }^{73}$ For King, the things we fear are the tools of the horror writer, not the purpose of horror fiction.

It is careful to distinguish between exceptional horrors, such as the thing that lives beneath Derry, and more banal, 'real' forms of violence. Richie considers the difference:

\footnotetext{
${ }^{72}$ Stephen King, It (1986; London: New English Library, 1987) 868. Capitals in original.

${ }^{73}$ King, Danse Macabre 18-20.
} 
Hadn't he sat in radio studios... reading news copy about such fellows as Idi Amin Dada and Jim Jones and that guy who had blown away all those folks in a McDonald's just down the road apiece?... monsters were cheap! Who needed a five-buck movie ticket when you could read about them in the paper for thirty-five cents or hear about them on the radio for free? ... It even had Its own sorry charm, because It came from Outside and no one had to claim responsibility for It. $^{74}$

Richie at first identifies real world horrors as comparable to Gothics, but then revises his comparison. It has charm, a quality obviously missing from the real killers Richie considers, and he attributes this charm to It coming from outside of the real; thus, nobody can be held accountable for it. It's appeal as well as its horror is based on its otherness. Because no person can be blamed for It's evil, It is placed beyond history, politics, the real. Richie seems to experience a moment of strange affection for the monster because he understands it as not relating to the familiar world of human nastiness. For Richie, this creates charm, but for readers, it facilitates entertainment and escapism. Whatever issues It might raise, the reader is directed away from them.

A similar observation is made when young Mike follows the tyre marks left by a cycle and makes up a story in his head about a monster snatching and killing the child who rode it, which, as it turns out, is exactly what has happened. He reflects that his story is 'Just like an Alfred Hitchcock Presents!... Mike shivered and looked around uncertainly. The story was somehow a little too real... He decided he didn't like the story. It was a stupid story. ${ }^{, 75}$ Mike decides he does not like the scary story he has invented at the moment it shifts from the realm of fiction to his real. It is possible to enjoy the story so long as it is understood as fictional; once it touches the real, its spell vanishes.

The horrors of It are carefully stage managed, and ultimately are constrained by their need to entertain. Real horrors are present, but tempered with the unreal. The monster is like a serial killer, but does not represent a serial killer. Where the popular

\footnotetext{
${ }^{74} \mathrm{King}, \underline{\text { It }}$ 580-1.

${ }^{75} \mathrm{King}, \underline{\text { It }} 271$.
} 
mythology of serial killers dwells on the sexual elements of their crimes, none of the child victims in $I t$ are molested by the monster, as the text carefully points out; ${ }^{76}$ that would be too much. It explores how the Gothic might function in a world increasingly framed in monstrous terms.

The text also carefully positions itself in relation to literature. The leader of the Losers, 'Stuttering Bill' Denbrough, is a wildly successful horror writer, with a similar career arc to King's own; King often writes about writers. In It, Bill's vocation is used to provide both a critique of the literary field and, more importantly, a statement of the differences between literature and the Gothic. Despite his success, Bill feels excluded from the literary field. He reflects on his unhappy experience at a university creative writing workshop:

There's one guy who wants to be Updike. There's another one who wants to be a New England version of Faulkner - only he wants to write novels about the grim lives of the poor in blank verse. There's a girl who admires Joyce Carol Oates but feels that because Oates was nurtured in a sexist society she is 'radioactive in a literary sense.' Oates is unable to be clean, this girl says. She will be cleaner. ${ }^{77}$

Bill's instructor, a minor poet, is sent up for his insistence that all narratives are allegorical and political, and this is presented as a difficulty for Bill, who is interested in writing genre fiction. Consequently, Bill is excluded by his fellow students and institutionally persecuted by his teacher, especially after he attempts to distance himself from the politicisation of literary practice in class:

'[...] Why does a story have to be socio-anything? Politics... culture... history... aren't those natural ingredients in any story, if it's told well? [...]' [...] They are thinking, he realizes, that maybe

\footnotetext{
${ }^{76} \mathrm{King}, \underline{\text { It }} 498$.

${ }^{77}$ King, It 132.
} 
there is a sexist death merchant in their midst. 'I mean... can't you guys just let a story be a story? ${ }^{, 78}$

Bill sells his first story to a pornographic magazine, drops the course, and sells his first novel at the age of twenty-three.

Despite his plea to limit political discourse, Bill's own position is hardly nonpolitical, representing a degree of conservatism and discomfort with late sixties campus radicalism. However, Bill's outburst also suggests something beyond the rejection of his classmates' politics; he distinguishes between 'story', which he believes lies beyond the political, and 'natural ingredients', which contain a degree of historic and political verisimilitude, but remain subsidiary to 'story'. Story seems to suggest more than simply narrative, but the entirety of the reading experience offered by a text. For Bill, the discursive aspects of mimetic representations and allegorical interpretations, when didactically stressed, diminish story itself.

Bill's concern relates to reading practice, and is suggestive of the difference between literary and Gothic habitus. He argues that some genre texts ought to be enjoyed in an oddly suspended, unreflective space, a reading practice quite different to the thoughtfulness and ironic distance that are hallmarks of literary reading. It is an argument for the pleasure of the text before its politics. Given that Bill is a character very much like King, this seems close to being an authorial instruction that seems likely to find approval amongst readers. King's narratives typically endorse altruistic, worldly pragmatism over ideologically driven concerns.

The broadly satiric pokes at Bill's classmates are interesting in that they focus on their desires, not to write, as such, but to be writers; the difference is that they want a sanctioned role within the world of letters rather than to actually produce stories, or even to find their own voices. King does not attack the writers he names, but instead the student's engagement with those writers; prior to Oates' reconsideration by feminists, King seems to be lampooning the critique of Oates that was grounded in feminist concerns and sixties idioms, while remaining clear that Bill, and by extension, King himself, are very different sorts of writers. This echoes the concerns voiced in How to Write.

\footnotetext{
${ }^{78} \mathrm{King}$, It 133. Ellipses in original except where indicated.
} 
It is keenly aware of the sort of book it is, and how it might be received. Patty Uris, wife of Stan, the Loser who kills himself rather than return to Derry to confront the monster, expresses her distaste for Bill's horror writing early in It:

It had not just been a novel [...] it had been a horrorbook. She said it just that way, all one word, the way she would have said sexbook. Patty was a sweet, kind woman, but not terribly articulate - she had wanted to tell her mother how much that book had frightened her and why it had upset her, but had not been able. 'It was full of monsters,' she said. 'Full of monsters chasing after little children. There were killings, and... I don't know... bad feelings and hurt. Stuff like that. ${ }^{, 79}$

Patty's critique is non-academic, but familiar; the Gothic simply is not nice. Patty is framed as the sort of dull, middle class conservative woman who might be sympathetic to the mode of censorious morality espoused throughout the eighties and epitomised, albeit in a different context, by the Parents' Music Resource Center. Readers will dislike Patty's objection, because it carries a judgement of the very activity they are engaged in. However, this reaction is countered, to a degree, as the objection leads Patty to a reflection on her Jewishness, and the occasion years ago when she was refused entry to her prom's after-party by her anti-Semitic peers. This extends into a wider survey of Patty's fear that she is often denigrated for being Jewish, and then her reflection returns to Bill's book: 'The book by Denbrough - the one she had tried to read and then put aside - was about werewolves. Werewolves, shit. What did a man like that know about werewolves? ${ }^{80}$

The irony is that Bill has been chased by a werewolf when he was younger, as this is one of the forms that It took to menace the Losers. Patty, however, believes that she knows where the real werewolves are; they are the people who suddenly reveal their hidden anti-Semitism and attack her. Patty's conception of a werewolf is, implicitly, allegorical. Bill Denbrough's werewolves, on the other hand, are more

\footnotetext{
${ }^{79} \mathrm{King}$, It 51 . Ellipses in original except where indicated

${ }^{80}$ King, It 54 .
} 
literal than that. Patty's resistance to the genre relates to her inability to shift into the non-allegorical reading practice that Bill argues for; her Gothic habitus is underdeveloped. However, the text does not upbraid Patty for her inability. By linking Patty's dislike of the genre to the bullying and discrimination she has been the victim of, It proposes that an inability to enjoy the Gothic might be grounded in genuine distress. It is aware of its position within the wider field of cultural production, acknowledging that it will meet criticism both from within the literary field, and from popular moral crusaders and their followers.

It simultaneously demands to be excused from the constraints of a literary reading while carefully acknowledging its relationship to literature. This is a carnivalesque reading practice, but not in a strictly Bakhtinian sense of the carnivalesque. ${ }^{81}$ Where Bakhtin uses the carnival to denote a period of inversion and disruption from the norm, this really only describes the carnival's myth of itself. Carnival is not a time of equality or misrule, although we might claim that it is, because this claim is part of the fun of carnival; carnival is a time of different rules, not absent rules. However, with this proviso, the connection of Gothic habitus to the carnival remains an interesting one, and the American Gothic often features the carnival or circus as a trope, as in Tod Browning's Freaks, Katherine Dunn's Geek Love or the sequence in Truman Capote's Other Voices, Other Rooms where Miss Wisteria pursues Joel through the carnival. It sometimes invokes this imagery, ${ }^{82}$ and of course, It most often appears as Pennywise the clown.

Beverly reflects on how often the Losers laughed over the summer of 1958 , and links laughter to fear: 'You laugh because what's fearful and unknown is also what's funny, you laugh the way a small child will sometimes laugh and cry at the same time when a capering circus clown approaches... ${ }^{83}$ Similarly, Mike imagines It calling the Losers back to Derry in terms of some childhood monster offering to play with them: 'Bring your jacks and your marbles and your yo-yos!' ${ }^{84}$ Both of these

\footnotetext{
${ }^{81}$ See Mikhail Bakhtin, Rabelais and His World, trans. Hélène Iswolsky (Bloomington: Indiana UP 1984) 7-11.

${ }^{82}$ See King, It 423, 25, 847.

${ }^{83} \mathrm{King}$, It 1065. Italics in original.

${ }^{84} \mathrm{King}, \underline{\text { It }} 880$.
} 
reflections cast It as having a gaming, childish appeal. Quite aside from the association with Gacy, the clown is representative of the carnival's spirit of performance and playfulness, a darker sense of which is shared by the Gothic. This is what readers like Patty Uris miss, reading the Gothic text as serious when it is playful. As Pennywise, It becomes a representation of the procedure of the Gothic itself.

Specifically, It's carnival seems to recall Ray Bradbury's Something Wicked This Way Comes. King discusses Something Wicked at length in Danse Macabre, noting its meditation on childhood and claiming that " $[t]$ he essence of evil, Bradbury suggests, is its need to compromise and corrupt that delicate passage from innocence to experience that all children must make. ${ }^{85}$ This theme occupies $I t$, and indeed $I t$ 's action is drawn from Something Wicked, where a pair of twelve year old protagonists, Will Halloway and Jim Nightshade, struggle against the monstrous freaks hidden within the travelling carnival that arrives in their small town. It is a rereading of Bradbury's classic, where instead of having the child heroes involve an adult librarian to help defeat the villainous Dark, the childhood heroes wait to become adults themselves, with Mike, significantly, becoming a librarian. For readers familiar with Bradbury's work, the likenesses between the two texts can only serve to highlight a particular contrast. Bradbury's work is often thick with a yolky nostalgia for boyhood, and when Edwards describes King as neo-Wordsworthian, he is noting that King celebrates childhood as an almost numinous state. However, where Bradbury's freaks present cartoonish danger, It and the populace of Derry are vicious killers. The terrors of Something Wicked are childhood things, but the horrors of It are basically adult.

It refers to other Gothics, too, but often this is a claiming of heritage or even an in-joke for horror fans rather than a substantial invitation to compare. When 'Bill thought And whatever walked in Community House, walked alone, ${ }^{86}$ a nod to the opening and closing of Shirley Jackson's The Haunting of Hill House, it does little more than remind us that It deliberately casts itself as a Gothic.

This intertextual referentiality might be seen as typical of a postmodern artefact. However, this is not really literary postmodernism; It's narrative is basically legible and determinate, and in as much as it is possible to within a supernatural

\footnotetext{
${ }^{85}$ King, Danse Macabre 363-79, 370.

${ }^{86} \mathrm{King}$, It 887. Italics in original.
} 
horror story, the text tends to popular, representational realism. Despite King's almost obsessive inclusion of popular cultural referents, the text is not a postmodern novel. I have argued that the text involves itself in historic, discursive issues without actually discussing them, per se, instead using them as the 'natural ingredients' of 'story'. Similarly, It has postmodern elements, but these achieve Gothic rather than literary or discursive significance.

Writing in the eighties, Umberto Eco suggested that

the postmodern attitude [is] that of a man who loves a very cultivated woman and knows he cannot say to her, I love you madly, because he knows that she knows (and that she knows that he knows) that these words have already been written by Barbara Cartland. ${ }^{87}$

Eco's playful definition underlines two significant elements of the postmodern 'attitude'. Firstly, that postmodernism can complicate things when we want to say something important, in this case an expression of love. Secondly, that the woman this postmodern paramour loves is very cultivated, and her considerable cultural capital is part of the problem her lover must resolve. In fact, Eco specifically frames a popular writer as a part of this problem, and while King is an exceptional rather than a typical popular writer, the general distinction between elite and demotic cultural locutions remains. This loosely agrees with the implicit consequence of Huyssen's analysis, that postmodernism typically features elite culture's inclusion of the popular, rather than the other way around. Postmodernity, as it is framed within academic or elite culture, tends to the discursive, and even as it appropriates the popular, remains distinct from it.

It's postmodern turn is limited, in addressing itself to Gothic practice rather than literature or pressing discourses. This is most obviously apparent in It itself, which is multiple, fractured, and inconsistent, functioning as a kind of metamonster. Where readers are familiar with a single monstrous trope being treated as a focal point in Gothic narrative (we gasp, it's a vampire! it's a ghost!) It is, amongst other things,

\footnotetext{
${ }^{87}$ Umberto Eco, Postscript, The Name of the Rose, qtd. in Peter Bondanella, Umberto Eco and the Open Text: Semiotics, Fiction, Popular Culture (Cambridge: Cambridge UP, 1997) 101.
} 
a werewolf, a monstrous bird, an enormous disembodied eye, a mummy, a large plastic statue, voices in the moon, violence perpetrated by other characters, the 'deadlights', a giant spider, and, most frequently, Pennywise the clown. It is ambiguous in the way we expect narrative, character or setting to be in postmodern literature. Literary postmodernism often forces us to consider the constructed nature of the text itself, but this is not the function of It's shifting identity. It's fluidity suggests the interchangeability of monsters in Gothic narrative, but the sustained mimetic illusion engendered by the text is never undermined, and readers are never forced to consider It as a construction. It's multiplicity draws from postmodernism, but does not create a postmodern effect.

The nature of It is one of the central concerns of the text; Mike investigates the monster's appearances throughout Derry's history. He discusses the monster with the other Losers, saying 'It's become a part of Derry, something as much a part of the town as the Standpipe, or the Canal [...] Only It's not a matter of outward geography... Somehow It's gotten inside' ${ }^{88}$ The monster has become a part of the psychic geography of the town. At the same time as considering the specific instance of It, Mike's suggestion is also a claim for the shifting role of the monster in the Gothic, because It is every monster, all at once. His claim echoes the shift from exterior threat to interior menace that McGrath and Morrow feel Poe achieved for the genre. ${ }^{89}$ As much as It is a giant spider or Pennywise, it is also the disposition of a town that turns a blind eye to vigilante activity, attacks on African Americans, homophobia and hate crime.

Mike knows that It exists within and without the individual. It deranges and even possesses the childhood bully turned escaped lunatic Henry Bowers and others, but It exists outside of the individual subject too. When the Losers track It to its lair, It is revealed as an admixture of Tolkien's Shelob, in that it is a giant spider, and Giger's aliens, in that it is surrounded by its own eggs. It is also like Lovecraft's gods, formless and alien, and King appears to refer to Lovecraft's weird prehistory when he

\footnotetext{
${ }^{88}$ King, It 499.

${ }^{89}$ Patrick McGrath and Bradford Morrow, Introduction, The New Gothic: A Collection of

Contemporary Gothic Fiction, eds. Patrick McGrath and Bradford Morrow (London: Picador, 1993) xi.
} 
depicts It's arrival on earth..$^{90}$ These associations do not give us a final version of It, and in the sewers it has no certain form, simultaneously manifesting as the mysterious 'deadlights' as well as the spidery thing. The monster is explained by Bill's research variously as a 'manitou', a 'tallus' an 'eylak', a 'loup-garou'. 91 These are all names for the shape-changers of various cultures, but it is telling that these names seem to carry no cultural association for the text. They are notions that contribute to It, but do not define it.

The text, which takes It's name, is permeated by the monster itself. It exists beyond Gothic precedents, cultures and easy categories, and has no single name. King has discussed his desire to bring together 'all the monsters' at once $;{ }^{92}$ and It is the device that manages this feat while still allowing the book to function as a coherent Gothic. One of the things that shifts It away from a specifically literary postmodernism is that despite It's legion forms, these do not create the discontinuities, complications and ambivalences we might expect.

Mike writes that it is as if he has 'fallen into a story', but not a 'classic screamer by Lovecraft or Bradbury or Poe', before reflecting that 'The gothic conventions are all wrong. ${ }^{93}$ Just as we expect postmodern literary texts of the time to playfully address their own conventions, It directly addresses Gothic convention, but this is Gothic rather than literary play. Here, It does not really encourage the reader to assume an ironic distance in order to negotiate the complexities of the text, and does not fracture the Gothic reading experience in order to play postmodern literary games. Instead, Mike's insistences address the sort of text It is, but also suggest a further turn of the screw, a promise that new horrors are to come.

Beverly imagines It in different terms to those employed by Mike. It has already menaced her, taking the form of a voice inside her head and seeming to coat her bathroom in blood, like some menstrual accident, and later, she thinks that '...for many [girls her age] sex must be some unrealized undefined monster; they refer to the

\footnotetext{
${ }^{90}$ King, It 744-5.

${ }^{91}$ King, It 664.

${ }^{92}$ Kanfer.

${ }^{93} \mathrm{King}$, It 154-5.
} 
act as It. ${ }^{, 94}$ It becomes the mystery of sexual maturity, and this reading is emphasised by an episode in the book far more troubling than any of the conventional horrors it offers. After the young Losers have repelled It, they become lost in Derry's extensive and uncharted sewer system; Bill is worried that whatever special bond the friends had is fading, and it is only that special bond, perhaps bestowed by a mystical force that opposes It, that has allowed them to achieve the remarkable. Beverly has an idea; she has sex with all of the other Losers. The characters are all eleven, or thereabouts. Beverly's idea works, and after pages of excruciating description, the Losers escape. ${ }^{95}$ While the episode seems inessential to the logic of the narrative, the encounter in the sewers is a confrontation with hatefulness and fearfulness, but also an encounter with sexuality.

Beverly's reading of It is close to familiar psychological, sexualised readings of the Gothic. This interest in psychological readings of the Gothic extends to the Losers' final confrontation with the monster, which, while enacting something called the 'Ritual of Chüd', features elements of contemporary therapeutic practice as well. Bill's adult confrontation with the monster occasionally reads like a counselling session. It confronts Bill with a ghoulish vision of his younger brother, Georgie; Bill still feels responsible for Georgie's death, but angrily rejects this guilt, crying out at the illusion, 'You're no ghost! George knows I didn't mean for him to die! My folks were wrong! They took it out on me and that was wrong! 96 This is some way from a confrontation with a monster that involves placing a stake in its heart or removing its head.

It pre-empts the ways in which it might be reflectively read. Bill interprets It as a mythical beast, Mike links It to historic evils and Beverly understands It as sexuality; all are interpretations of the monster readers might accept, and the latter two, in particular, are readings Gothic studies might embrace. McGrath and Morrow claim that Gothic forces have shifted from without the human psyche to within it; It exists both within and without the populace of Derry. Gothic studies argues that the Gothic is a tour of hidden psychologies and sexualities; It offers therapy and early

\footnotetext{
${ }^{94} \mathrm{King}, \underline{\text { It }}$ 1065. Italics in original.

${ }^{95} \mathrm{King}, \underline{\text { It }}$ 1054-6, 1061-7.

${ }^{96} \mathrm{King}$, It 432, 1021.
} 
sexual experience. It does not need criticism to draw these points out of it. The text tends to interpret itself, rendering the discursive possibilities it opens closed before we approach them, pushing the text away from literary practice. This directs readers' attention away from any real-world issues the text might raise.

The text's disinterest in discursivity is exemplified in Henry Bower's final attack on Mike. Henry, a coarsely drawn redneck, was once the town bully, but by 1985, he is an escaped lunatic in It's thrall. Henry pursues Mike with a knife, shrieking long strings of almost caricatured racist abuse at the Loser, "You nigger boogie night-fighter jungle-bunny apeman coon!" 97 There is no doubt Henry's speech is suggestive of real racism, but its emotional power is undermined both because he is a slobbering idiot, and, within the fairly rigid moral arrangement of King's narratives, Henry is unambiguously and irremediably a baddie. Henry is beyond the pale, pathetic in a way his victim is not. As Henry's assault proceeds, we encounter one of the text's crudest shocks:

There was a loud, vibrating ka-spanggg! sound, and Stan Uris's head popped up from behind the desk. A spring corkscrewed up and into his severed and dripping neck. His face was livid with greasepaint... Great orange pompoms flowered where the eyes had been. This grotesque Stan-in-the-box head nodded back and forth at the end of its spring... Its mouth opened and a squealing, laughing voice began to chant: 'Kill him, Henry! Kill the nigger, kill the coon... 98

Of course there is a racial element in the violence being directed towards Mike, but this is so clearly stated that the tools of criticism are utterly unnecessary. This is too simple to constitute an examination of racism; it is only a 'natural ingredient' in the 'story'. In fact, there's an odd reversal at work here, in that the more familiar critical procedure, where we might look at a monster in a Gothic and see that it represents a racist fear becomes pointless; here, Henry's racism is only a cover for It.

\footnotetext{
${ }^{97} \mathrm{King}, \underline{\text { It }} 907$.

${ }^{98} \mathrm{King}, \underline{\text { It }} 908$.
} 
Where American Gothic studies typically directs us to the real, It insists on the authority of the Gothic field to create a separated, carnival space in which we are directed towards the fearful, horrible and forbidden, but largely divested of their complicating politics. It engages with the kinds of genuinely discursive ideas that were becoming involved in the field, and retools them to its own, popular, specifically Gothic ends. By making It not a single monster but all possible monsters, the book achieves a novel expression of the Gothic, resolving the problem of dull reiteration that Eco proposes, adopting postmodern techniques but shunning the discursivity and cultural capitals native to postmodernism. Rather than troubling his readers with the complexities of the real, or even necessarily alerting them to genre polemics the text is engaged in, King directs them, time and again, to the 'story', the simple experience of reading. Readers are returned to the business of the contemporary Gothic; in this case, Stanley Uris' dripping head wobbling improbably on a spring.

\section{Mysteries of Winterthurn}

Much of Oates' enormous body of work tends to the macabre, but her 'Gothic quintet' stands apart from the loosely realist and contemporary emphases of much of her work. The quintet consists of the novels Bellefleur (1980), A Bloodsmoor Romance (1982), Mysteries of Winterthurn (1984), My Heart Laid Bare published in 1998, but originally drafted in the early eighties, and The Crosswicks Horror. This last remains unpublished, although an extract was published in The Partisan Review in 1983. Each of these Gothics is set largely in the nineteenth century, and plotted so as to feature a series of unfortunate events. The novels often pastiche fussy, nineteenth century narrative voices.

Like King, Oates has never enjoyed an uncontested position within the literary field, but unlike King, her work is without exception literary in its ambition. Certainly, her publications participate in the literary field, but often reviewers are reluctant to accord them literary value. Typical of the critiques levelled at Oates is a piece by James Wolcott, ostensibly a review of A Bloodsmoor Romance, entitled 'Stop Me Before I Write Again: Six hundred more pages by Joyce Carol Oates' that is really a general consideration of Oates' style and her prodigious output. Wolcott is concerned by Oates' obsessive presentation of violence, by what he sees as the 
careless, even reckless nature of her prose, and by her occasionally po-faced tone. He argues:

The novels of most so-called serious writers are usually exercises in craft and care, but A Bloodsmoor Romance seems a freak of circumstance, a speck of inspiration that somehow metamorphosed into a word-goop with a ravenous case of the eaties. ${ }^{99}$

Wolcott explicitly links Oates' oeuvre to the film The Blob; if we believe his review, Oates' fiction is like the thing beneath the raft in the King story, consuming, voracious, monstrous. In this understanding, Oates' work is not careful and considered enough to be accorded the title 'literature'.

In general, Oates scholarship has been hindered by the sheer volume of her work, which eclipses even King's enormous production. The author of two Oates monographs admits to finding it impossible to read everything Oates has written, let alone everything she has read. ${ }^{100}$ Given the pragmatic difficulties of Oates scholarship, it is unsurprising that the Gothic quintet has benefited from only a handful of critical treatments. While Oates might do herself few favours with the sheer scale of her publication (fifty-five novels and novellas, thirty-two short story collections, eight collections of poetry, and at least thirty-four other publications as I write this, with more forthcoming), and despite critical scepticism, she nevertheless maintains considerable standing within parts of the world of letters, and has, apparently, been considered for the Nobel Prize on several occasions. ${ }^{101}$ Her value continues to be negotiated.

As discussed above, postmodernism was a significant feature of the period's literary zeitgeist, which often attempted to bridge the divide between high and popular cultures. Wolcott identifies A Bloodsmoor Romance, and by extension, the whole of

\footnotetext{
${ }^{99}$ James Wolcott, "Stop Me Before I Write Again: Six Hundred More Pages by Joyce Carol Oates," rev. of A Bloodsmoor Romance, by Joyce Carol Oates, Harper's September 1982: 67.

${ }^{100}$ Joanne V. Creighton, Joyce Carol Oates: Novels of the Middle Years, Twayne's United States Authors Series (New York: Twayne Publishers, 1992) x.

${ }^{101}$ Johnson, Understanding Joyce Carol Oates 25.
} 
the Gothic quintet, as involved in this bridging when he writes that Oates is 'using pop literature to unmask pop literature - subverting the conventions of feminine fiction to reveal how those conventions shrouded the true appetites of women in layers of silk and fluff.' 102 This 'subversion' is what we expect of the postmodern text, but the space between popular and elite culture becomes especially relevant to Oates, in that the critical arguments that surround her relate to whether or not her work qualifies as literature in the valorised sense, or as something less. This concern is played out through the Gothic quintet, as the first novel in the cycle, Bellefleur, was promoted more aggressively than Oates' previous work, targeting an audience of 'ordinary people who might not follow serious literature'; although this might simply be the result of acquiring a new publisher who was keen to give the book a substantial 'push'. ${ }^{103}$ The Gothic quintet tries to be both popular fiction and serious literature.

Mysteries of Winterthurn, the third instalment in the quintet, is a novel by turns entertaining and frustrating. Tremendously complex, it is a meeting of Gothic practice with the postmodern literary novel of the eighties. However, Oates' postmodern turns and tics undermine her performance of the Gothic, leading to a text that perhaps succeeds as literature, but remains at best confused as a Gothic. The wider implication of this is that the literary field cannot simply appropriate the Gothic for its own ends without carefully orchestrating Gothic as well as literary performances.

Winterthurn is divided into three sections, each relating the investigation of a crime by Xavier Kilgarvan, detective extraordinaire. The cases are recounted by the novel's voluble, opinionated narrator or 'editor'; this figure is unidentified, despite Brenda Daly's ill-founded assertions that it is Perdita, Xavier's cousin and eventual bride. ${ }^{104}$ The three sections are sequential but basically self-contained: 'The Virgin in the Rose-Bower; or, the Tragedy of Glen Mawr Manor', 'Devil's Half-Acre; or, the

\footnotetext{
${ }^{102}$ Wolcott 68.

${ }^{103}$ Lucinda Franks, "The Emergence of Joyce Carol Oates," Joyce Carol Oates: Conversations 1970 2006 ed. Greg Johnson (Princeton: Ontario Review P, 2006) 94.

${ }^{104}$ Brenda Daly, Lavish Self-Divisions: The Novels of Joyce Carol Oates (Jackson: UP of Mississippi, 1996) 166-78.
} 
Mystery of the "Cruel Suitor", and 'The Bloodstained Bridal Gown; or, Xavier Kilgarvan's Last Case'.

It is difficult to summarise Winterthurn's dense and indeterminate plot. Its style, a pastiche of pedantic nineteenth century language, foregrounds its constructed, textual quality. The plots are ostensibly detective narratives. Detective fiction is a more recent development than the Gothic, but it has developed its own habitus and a field in much the same way, and engenders a set of procedures that revolve around a crime and its solution. However, while referring to the genre, Winterthurn breaks the approximate, fuzzy rules of detection by refusing to provide satisfactory solutions. The title is appropriate in that as much as the text is a detective fiction, it also describes mysteries in the sense of things that are irresolvable, or even strange rites.

Winterthurn also demarcates itself as a Gothic, through the peculiar nature of the crimes involved, the frequent incursion of the supernatural, along with depictions of weird sexuality, morbid states and sadism. In particular, its feminist concerns locate it within the newly minted 'tradition' of the female Gothic. In her 1985 afterword Oates explains that she wanted 'to explore historically authentic crimes against women, children, and the poor' ${ }^{105}$ For her, the Gothic is an extension of the real world, rather than an escape from it. ${ }^{106}$ As closely as this rehearses the arguments of Gothic studies, however, Oates' polemic intentions are not played out in the text in any uncomplicated way.

The first case, 'The Virgin in the Rose-Bower', centres on the death of Abigail Whimbrel's child. Abigail goes to stay with her cousins, Georgina, Thérèse and Perdita, at Glen Mawr Manor. Abigail is assigned the 'Honeymoon Room', and although she locks herself and her infant boy in for the night, she is found raving the next morning, her child mauled and dead. The youthful Xavier, poor cousin of the Kilgarvans of Glen Mawr, investigates. While some denizens of Winterthurn attribute the terrible assault to Jupiter, the old dog, or to an infestation of giant Norway rats,

\footnotetext{
${ }^{105}$ Joyce Carol Oates, "Afterword (1985 Edition)," Celestial Timepiece: A Joyce Carol Oates Homepage: Mysteries of Winterthurn, 18 Jan. 2010 <http://jco.usfca.edu/works/novels/ winterthurn.html>.

${ }^{106}$ Joyce Carol Oates, "Author's Afterword (2007 Edition)," Celestial Timepiece: A Joyce Carol Oates Homepage: Mysteries of Winterthurn, 18 Jan. 2010 <http://jco.usfca.edu/works/novels/ winterthurn.html>.
} 
others believe that Glen Mawr is haunted or accursed. Xavier's investigations lead him to the conclusion that Georgina has been the victim of incest, abused by her father Erasmus. He believes that Georgina has hidden the mummified remains of the many babies, born or miscarried, that have been a consequence of Erasmus' abuse in a locked sideboard in the attic of Glen Mawr, and that these have returned as spirits, manifesting through an extensive trompe l'oeil painting of the Madonna, the infant Christ, and numerous sinister cherubs, on the walls of the Honeymoon Room.

This sequence of weird events and revelations establishes a set of parameters for the action that occurs in Winterthurn. We are led to believe that the town is somewhere the dead might violently return, a proposal not uncommon in the Gothic. However, the manner in which the apparent plot is articulated creates substantial ambiguities, which multiply later in the text, requiring readers to carefully weigh the information presented so as to ascertain what has occurred. While the solution described to the first case seems to be the only possible option, nobody other than Xavier sees the dead babies, and only Abigail is depicted as seeing the painting's devils in flight, although Xavier does detect 'actual writhing' within it. ${ }^{107}$ A further complication is that Xavier discovers that Georgina is the mother of the dead babies through a vision, hardly the ratiocinative clarity the detective story normally requires. Nevertheless, the reader is likely to accept Xavier's vision as 'true'; at least, until Xavier has another vision during his investigations of the axe murders that come later, suggesting Ellery Poindexter is the murderer, which, ultimately, is unlikely. Xavier is presented as a psychic detective, but his psychic ability is far from infallible.

Winterthurn offers the reader a solution to the first case that is contingent on Xavier's extraordinary powers of perception, which we later discover to be flawed.

Despite these ambiguities, 'The Virgin in the Rose-Bower' is a narrative that clearly signals its genre. It frames itself as a female Gothic, thus inviting feminist readings, ${ }^{108}$ and seems to consciously aim at describing the concerns Gilbert and Gubar found in their critical articulation of the genre. Chief Justice Erasmus Kilgarvan is an archetypal patriarch, determining the law. Both Georgina and Perdita are at least metaphorically madwomen, Abigail literally so, and they are all trapped in

\footnotetext{
${ }^{107}$ Joyce Carol Oates, Mysteries of Winterthurn (London: Jonathan Cape, 1984) 102.

${ }^{108}$ See Creighton 48-56; Daly 136-78.
} 
confined spaces of one sort or another. Indeed, Georgina seems to be described with reference to two Gothic 'heroines' of very different kinds, both, in their way 'madwomen': Emily Grierson of Faulkner's ‘A Rose for Emily', and Emily Dickinson.

Like Emily Grierson, Georgina once had a suitor, Mr Guillemot, and like Emily, her father has ruined her chances of a match. ${ }^{109}$ Similarly, the discovery of the dead bodies that Georgina has been hiding coincides with her own death. More explicitly, Georgina is the poet 'Iphigenia', who pens Dickinsonesque poems, complete with dashes and odd capitalisations, which only find an audience after her death. It seems that Dickinson has acquired a Gothic attribution, and is sometimes included in genre collections. ${ }^{110}$ Details of Georgina's education loosely echo Dickinson's. Where Dickinson was the reclusive 'woman in white', Georgina is the 'Blue Nun', although this strikes an odd note. Why name the faux-tragic heroine after a notorious brand of table wine? Oates' postmodern sensibility is as baffling as it is sly. Nevertheless, 'The Virgin in the Rose-Bower' strongly signals what sort of text Winterthurn is.

Complications ensue in the 'Devil's Half-Acre', which relates an older Xavier's investigation into a series of murders; the bodies of five young, lower class women are found in the Half-Acre, seemingly ritualistically slain. Winterthurn's suspicion falls on the Jew Isaac Rosenwald who is arrested, tortured, made to confess to a crime he obviously never committed, and then summarily lynched by the Klanlike Brethren of Jericho. Xavier, however, is convinced that young man-about-town, Valentine Westergaard, is responsible for the killings, and pursues his investigation until he is able to force the arrest and prosecution of Valentine. Xavier is shocked when his own brother Colin, who seems to be in thrall to Valentine, confesses in an open court to helping Valentine ritualistically murder the young women. Valentine confesses to his crimes, but claims he was possessed by the spirit of the 'Bishop', a local madman of note from the eighteenth century, buried out in the Devil's HalfAcre. In the light of this claim, and much to Xavier's horror, the jury finds Valentine 'not guilty'.

\footnotetext{
${ }^{109}$ Oates, Winterthurn 36.

${ }^{110}$ Charles L. Crow, ed., American Gothic: An Anthology 1787 - 1916 (Malden: Blackwell, 1999).
} 
Again, both of the narrative's principal evils, Valentine and the Brethren of Jericho, represent various forms of patriarchal power. Unlike the first case, the solution to the second is simple in the sense that the reader is left knowing what occurred and which character was responsible for causing the action. Valentine Westergaard does indeed seem to be responsible for the murders of the Half-Acre. The complicating factor here is the issue of Valentine's culpability; there is a sense that the reader is expected to reject the jury's verdict that Valentine was not himself, in fact was possessed, and thus not to blame for the murders. Xavier fumes over the verdict:

He took no solace from the fact that, in such cities as New York, Boston, and Philadelphia, the verdict in Westergaard's favor had been greeted with incredulity, and outright scorn... For closer to home... sentiments were quite the reverse; and the Winterthurn Gazette spoke for the great majority, in hailing the verdict as a stirring vindication of the American tradition of trial by jury, nay, a tribute to the American virtues of common sense, and fair play, and Christian compassion. ${ }^{111}$

Claiming that one is possessed is hardly a credible defence, and the satire here is on the supposed ability of provincial juries of the era to protect powerful or popular figures in their community. Nevertheless, the difficulty remains that Winterthurn has already been presented as a place where ghosts walk and pictures spring into demonic life. If the supernatural is accorded the status of reality it so often is in the Gothic text, then Valentine's ludicrous defence seems at least plausible. After all, in The Exorcist, a narrative of possession current at the time, we cannot hold Reagan culpable for the death of Father Merrin.

While the narrator's tone ironically disapproves of the verdict, and is thus in agreement with Xavier's point of view, the position of Winterthurn's 'great majority' has to be admitted as a tenuously possible contrary. At the same time, this majority allowed and even endorsed the lynching of Isaac Rosenwald, and thus are hardly an

\footnotetext{
${ }^{111}$ Oates, Winterthurn 340.
} 
appealing group for readers to position themselves beside. Perhaps this complication can be read as a clever pricking of readers who desire determinate narrative glosses over the messiness of real crime, who want to see justice done without questioning what something as certain as justice might be in an uncertain world.

This seems an adequate reading if we understand Winterthurn as literature. However, it creates difficulty for readers who are trying to enjoy it as a detective fiction or as a Gothic. This is not necessarily a question of insufficiently competent reading either. Detective fictions require a solution; Gothics use ambiguity to create a Gothic experience. In It, we cannot tell what sort of monster It is, but this allows the deployment of any number of bizarre frights. This ambiguity is carefully managed so that it is unlikely to break the reader's involvement in the text by demanding careful, reflective reading practices. A more famous instance is 'The Turn of the Screw', which stages a series of woozily uncertain scenes and an indeterminate ending to further trouble its readers. It is possible to read the James novella without breaking out of an immersed reading experience, but if we do, and wonder about the substance of the Governess' fears, we are turned to the twinned Gothic possibilities of madness and haunting; the ambiguity is used to a certain end, and engenders a specifically Gothic mode of reflection. 'The Turn of the Screw' is important to the practice of the Gothic narrative in the last century not because it is stubbornly indeterminate, but because its indeterminate fusing of madness and the supernatural is useful to Gothic performance.

The ambiguity associated with Valentine is of a different order, recalling playful postmodern literature rather than a specifically Gothic purpose. We are not provided with information that would allow us to assess whether Valentine's subjectivity was invaded by something else, whether his agency was compromised, and whether it is fair to hold him culpable. Readers are placed at a considerable remove from Valentine, and our reflection turns us not to possible Gothic horrors but to Valentine's allegorical role, representing the patriarchal tendency to use positions of social authority to victimise women while evading punishment.

If we choose to accept a reading that interprets Valentine's defence as a sham and insists on his responsibility for his actions, another problem quickly emerges. In rejecting this supernaturalism, we need also to reconsider the events of 'The Virgin in the Rose-Bower': perhaps Abigail Whimbrel killed her own child? Perhaps it was the Norway rats after all? In this case, given that Abigail was presented as actually seeing 
the things which killed her baby, and Xavier has substantiated Abigail's perception as a solution, readers will need to reconsider their relationship with the text. If we cannot trust these claims, then it is apparent that the editorial voice is fabricating events, misdirecting us. In turn, this means we cannot simply immerse ourselves in the world of Winterthurn, but must read sceptically, critically, weighing and judging the claims of the text. We become aware of the text itself, its artifice. This is typical of postmodernism, but does not allow readers to involve themselves in the immersive experience of the Gothic; it is a different reading practice. We withdraw our commitment to the drama of Xavier and Valentine, and reassign our interest to the play of the text itself.

Literary rather than Gothic ambiguities multiply in 'Devil's Half-Acre'. Even more troubling than Valentine's evasion of any punishment he may or may not deserve is the refusal of the narrator to clarify whether Xavier, in fact, ever escaped from the pit of quicksand he fell into while looking for clues in the Half-Acre. If Xavier is dead, it seems to have made remarkably little difference to his status as a character, although it is only after the incident in the quicksand that he starts lapsing into alcoholism, amnesiac states and odd fugues. The narrator is unable to explain Xavier's escape, ending his or her consideration of the matter by saying that Xavier survived,

at least in a manner of speaking. As to whether he shook off the chill wisdom derived from the sudden and irreversible shifting of the planes, and violation of the fabric of Reality itself: that is another matter entirely: and the reader must form his own judgment. $^{112}$

Indeed. Although the text toys with the idea that Xavier's death might have occurred in literal terms, it is basically allegorical in nature. This kind of textual play refuses to present a fictional 'real' which readers can become immersed in, instead promoting a reflective distance from the text.

\footnotetext{
${ }^{112}$ Oates, Winterthurn 287.
} 
Creighton believes 'it is hard to overestimate how teasingly playful this book is, with its shifting ontological levels', ${ }^{113}$ using the rhetoric of play, which is often invoked to explicate the quirks of postmodern texts. Play operates by suggesting a set of 'rules' even if these are fleeting and changeable, and demanding that players are invested in those rules. Play is not a nebulous, unformed space, but a space apart, which operates differently, but legibly, as a negotiated area of shared action.

Winterthurn plays within the 'rules' of literary postmodernism, shuffling through ontological levels, but in doing so, undermines the ability of the reader to immerse themselves in a text the Gothic requires.

In Winterthurn the distinctions between planes of textual 'reality' are effaced, creating a pervasive dreamy quality, where it is impossible to pick exactly where the quotidian shaded into horror, where one plane was left for another. It is something of a critical commonplace to label Gothics oneiric, and sometimes this is accurate. A handful of Gothics, especially texts like Otranto and Vathek, are indeed dreamlike as a consequence of their persistent strangeness. However, most Gothics, particularly those that are contemporary with Winterthurn, carefully delineate the movements that occur between ontological states, what Oates calls the 'shifting of the planes'. When a text like It or Pet Sematary shifts between ontological levels, it points toward the incursion of dark forces into the narrative's 'real'. Oneiric narrative sequences are clearly motivated and demarcated; in contrast, Winterthurn's play is, in terms of its performance of the Gothic, aimless and unclear.

A similar problem emerges when we consider the doubling of Xavier and Valentine. Xavier believes Valentine thinks of him as his doppelgänger, having discovered a poem to this effect in Valentine's rooms. ${ }^{114}$ In the chapter 'A Romantic Interlude', Xavier wonders if it was he, not Valentine, who committed the murders. Perdita, who has always been attracted to Xavier, seems to express an attraction to Valentine and his actions, ${ }^{115}$ suggesting that the doubling of the two characters is not simply a psychological state experienced by the detective and his quarry, but a wider textual effect. As Xavier and Perdita walk out, Xavier seems to experience the

\footnotetext{
${ }^{113}$ Creighton 56.

${ }^{114}$ Oates, Winterthurn 284.

${ }^{115}$ Oates, Winterthurn 293.
} 
murderous sexual urges that Valentine has. The couple enter a deserted and ill-kempt area of Juniper Park, similar to the bleak landscape of the Half-Acre itself, indeed, virtually a double of that cursed place. This prompts Xavier to reflect 'with a thrill of horror: "Here, in such a setting, amidst such mist, and secrecy, and anonymity, - what should not befall us? What has not already occurred, not once, but numberless times ?", 116 This is not the Devil's Half-Acre, but the place is made to substitute for it, as the gloomy climatological paraphernalia of the Gothic are rolled in. The sense of place drives Xavier towards violence: as the lovers argue, Xavier looks on Perdita and 'feels a wave of vertigo, as if he had drawn near to a mirror, and his own breath had begun to cast a pall of steam over it, obscuring its image: "It is I, in enchanted guise; she is my own soul..." 117 . At this moment, he is filled with an explicit urge to assault and even rape Perdita.

This is not Xavier Kilgarvan, the amiable young man we are familiar with. Xavier's identity seems to be compromised and confused through the conceit of doubling Xavier with both Valentine and his cousin, in a place which is also a double, while he experiences an uncanny compulsion to repeat another character's actions, a character who himself may have been overwhelmed by the spirit of another figure. This is a complex arrangement, a massed doubling that does not so much produce affective uncanniness as tease interpretation. Read as literature, it seems fair to argue that Oates is playfully querying the convention of 'character' in fiction, and even the necessary interrelationship of detective, villain and victim in the detective narrative, all of which must work together to facilitate the reader's pleasure. However, as before, when read as a Gothic, the text's treatment of the double pushes it into dysfunction.

When Gothic texts present doppelgängers, they are typically problems within the world of the text rather than queries about textuality. Freud's essay on the uncanny discusses the double as an instance of that unheimlich sensation; Poe's 'William Wilson' uses the double as an allegory of a divided conscience and as a narrative conceit; Jekyll and Hyde does something similar. In each of these instances, the doubling is an important element in the text, central to narrative, affect, or

\footnotetext{
${ }^{116}$ Oates, Winterthurn 299. Italics in original.

${ }^{117}$ Oates, Winterthurn 299.
} 
argument. Here, however, the multiple doubling does not achieve an especially uncanny effect, nor is it any more important to Winterthurn as a whole than any of the other postmodern manoeuvres within the text. Where literature is a practice that, for much of the twentieth century, has developed increasingly sophisticated ways of including quirky and fractious textual strategies within the remit of its 'game', Gothic practice has been more interested in other forms of novelty, producing texts which are more intense, perverse, gorier, and so forth. Xavier's doubled experience is a literary gag, but as a Gothic, is a confusing, throwaway effect.

Winterthurn concludes with 'The Bloodstained Bridal Gown'. Xavier, now approaching his middle years, investigates the axe murder of Perdita's husband, the Reverend Harmon Bunting, his apparent lover, Amanda Poindexter, and his mother, Mrs Letitia Bunting. Amanda and the Reverend are found in the rectory, dead, and in each other's arms. Perdita is found, bound and gagged in her own bloodstained bridal gown upstairs, claiming that she has been raped, although she refuses Dr Hatch's examination, and the text is careful to avoid having Perdita identify her assailant. Jabez Dovekie, the red-headed iceman, is suspected of the murder, but when Dovekie is arrested, the police beat him to death before Xavier is able to question him. Xavier becomes convinced that Amanda's cuckolded husband, Ellery Poindexter, is responsible for the murders and presses ahead with his investigation, becoming increasingly distraught and obsessive. Xavier suffers a mental collapse, but his recovery allows the novel to end on a note of conventional happiness, as Perdita, entirely recovered, weds Xavier, and their friends Thérèse and Murre Pitt-Davies join them in a double marriage ceremony. This odd conclusion is presumably a joke at the expense of the romance Gothics popular throughout the sixties, exemplified by Mistress of Mellyn, where regardless of whatever horrors had been discovered, a happy marriage was called for to provide an ending.

The complications of the earlier two episodes become absurd in 'The Bloodstained Bridal Gown'. We must presume that Xavier is not dead in any literal sense, and that despite the fact he might also be Valentine, or Perdita, or, perhaps, the 'Bishop', he remains identifiable as Xavier; it is easier to think of the character as 'Xavier' rather than simply Xavier at this point. The investigation fingers three suspects, Dovekie, Poindexter, and Xavier himself, but none of them offers satisfactory solutions to the mystery. Oates notes in her afterword that the 'special puzzle of "The Bloodstained Bridal Gown" has to do with the detective's inability to 
solve the crime when various clues and motives will strike the attentive reader as selfevident'. ${ }^{118}$ Indeed, the scrupulous reader can be reasonably certain that it is Perdita herself who is responsible for the murders, enraged by her husband's sexual coldness, his refusal to let her go bicycling, and his attempts to wrest the royalties of the Iphigenia poems from her. However, it is interesting that when Joanne V. Creighton discusses the novel, she cites her correspondence with Oates, rather than relying on the text itself, to establish Perdita's guilt. Despite Oates's faith in the 'attentive reader', even elite academic specialists find themselves unable to determine the action of the text; in confirming Perdita is the murderer, Creighton mentions another critic, Cara Chell, who identifies Xavier as the murderer instead. ${ }^{119}$

In any case, although there is no way we can ascertain what has happened beyond the mere sketch of Perdita's actions, once we grasp that she is indeed responsible, another possibility emerges: that Xavier himself has been involved in the murders. However, there is little clue as to the extent of his involvement. He claims to his friend Murre that he was indeed the murderer, although whether or not the reader will credit this confession is uncertain. If this is so, it certainly means that the voices of both the narrator and the central character have been carefully arranged so as to deceive the reader.

Further compounding this doubt, we cannot tell when Xavier's perceptions, as reported by the narrator, are clouded by his consumption of liquor and opium, and we can only guess when he has entered amnesiac or fugue states as this is not signalled outside of the Hotel Paradise sequence. There, he assumes a number of disguises, combs the whorehouses of Rivière-du-Loup, and succumbs to an alcoholic breakdown in the depths of the notorious brothel. At this point, Xavier receives information that allows him to locate Poindexter and (accidentally?) kill him in a fight.

Winterthurn ends in interpretive fog. Xavier, the detective, has brought no satisfactory resolutions to these mysteries. The first case is resolved not by ratiocination but through vision; the second is solved but it is unclear if justice has been served; and in the third case the detective marries the murderer, and may have been involved in the murder himself. Worse, Xavier has hounded an innocent man,

\footnotetext{
${ }^{118}$ Oates, "Afterword (1985 Edition)".

${ }^{119}$ Creighton 54, 55.
} 
and is at least partially responsible for his death; and the dead man becomes a scapegoat, not that another was needed after the death of Dovekie, to enable Perdita to escape justice, just as Valentine did before. All of these points only become apparent on reflection after close reading, and given that Oates found it necessary to clarify the basic events of the narrative in her later afterword, for many readers these points may not be apparent at all. While this doubtless represents a further literary 'subversion' of detective fiction, it also represents a frustration of the pleasures of detection narrative.

Xavier becomes imprecise, filling the space of a character and even overflowing it, without necessarily being one. However, one of the more puzzling claims that Oates makes comes from her journal, which she cites in the 2007 afterword, saying how she wants to stay with "congenial Xavier Kilgarvan forever. Where will I find a character quite like my "detective" after this?" ${ }^{120}$ This suggests that Oates experiences the familiar, although critically under-examined phenomenon of gaining pleasure from the imagined presence of a character, the illusion of an intersubjective experience. Yet most readers will find Xavier hardly more than a cipher. Cologne-Brooks suggests 'Perdita and Xavier seem explicit narrative constructs rather than "life-like" in the realist sense'. ${ }^{121}$

How is it that Oates should find Xavier such a compelling figure? Part of the puzzle is that Xavier is elaborately dispersed as a textual construct. He is doubled by Perdita, Valentine, and even the 'Bishop', making it seem uncertain that he is confined to the figure that the text labels 'Xavier'. Characters become provisional only, and 'Xavier' is involved with 'Perdita', 'Valentine' and others. Valentine's claim that the 'Bishop' possesses him is, in all its ambiguity, replicated amongst many of the characters, possessing or possessed by Xavier. While it is only ever an illusion to see a textual character as possessing some kind of 'self', the illusion is a familiar one; we have the sense that textual characters fictionally 'exist', even when we are not reading about them at that moment. This sense is especially important in detective fiction, because it allows us to attribute motives to characters and postulate their

\footnotetext{
${ }^{120}$ Oates, "Author's Afterword (2007 Edition)."

${ }^{121}$ Gavin Cologne-Brooks, Dark Eyes on America: The Novels of Joyce Carol Oates (Baton Rouge: Louisiana State UP, 2005) 128.
} 
undescribed actions. Yet in Winterthurn, the reader's ability to do this is impaired by the text's refusal to describe where the boundaries of character lie.

Our sense of Xavier as a sovereign figure is further smudged as he assumes a number of disguises in the course of his third investigation, meaning that other characters treat him as if he were someone other than Xavier. These selfconcealments become especially important as Xavier enters the Hotel Paradise, wearing a red wig and beard, assuming the signs most often used to describe the suspect Jabez Dovekie, who he still believes may have helped Poindexter in executing the murders. As Xavier becomes delirious with liquor, mental illness and sheer confusion, he realizes he may not be able to find Poindexter, who himself might have any number of identities in Rivière-du-Loup:

Might the person Xavier sought not be "Old Bull"? - or "Red"? or "Buck"? - or "The Fox"? Might he not be "Trouble"? - or "Gnasher"? - or "Zach"? - or "Ironlocks"? - or "Bibs"? - or "Kooch"? ${ }^{122}$

Xavier, his identity diffused, concealed, disintegrating, is seeking a man he has misidentified, whose identity is here multiple, in a carnivalesque place where 'gentlemen' substitute one identity for another, indulging in, or inflicting, 'a night's savage sport'. ${ }^{123}$ Rivière-du-Loup, river of the wolf, alludes to the wolfish pleasures available, without entirely discounting the meaning of 'loup' as a kind of mask; the Hotel Paradise is the centre of a vicious carnival. As with the massive doubling present in the second mystery, the degree to which individual identities are blurred becomes uninterpretable, significant as a literary-philosophic play on the effaceable nature of the self, but lacking the specific meanings that doubling has in the Gothic.

Xavier, whatever that textual signification finally denotes, becomes concerned that he is only a mirror, reflecting action: "I am indeed a mirror suspended above an abyss," he thought, "possessed of no content, and reflecting nothing save

\footnotetext{
${ }^{122}$ Oates, Winterthurn 454.

${ }^{123}$ Oates, Winterthurn 454.
} 
motion..." 124 The same image appears in an earlier description of Xavier too. ${ }^{125}$ If we understand Xavier as this mirror, then the image suggests that we read the images perceived on his surface more than we read Xavier 'himself'. He appears as what he reflects, the abyss and whatever presumably monstrous thing that moves within it, and has thereby become monstrous himself, or at least, the image of a monster. Certainly, this is congruent with his decision to marry Perdita, the murderess.

The image of the mirror and the abyss recalls the famous aphorism from Beyond Good and Evil, 'He who fights with monsters should be careful lest he thereby become a monster. And if thou gaze long into an abyss, the abyss will also gaze into thee. ${ }^{126}$ Appropriately enough, Winterthurn is a text that wants to be assessed beyond the conventional notions of good and evil we find in King's narratives. Indeed, given the precarious access we have to the 'real' of Winterthurn, via a sketchy, unreliable hero and deceptive narrator, we have little other option than to read sceptically and withhold immediate assessments of what is wrong and what is right, and even what has occurred.

However, Winterthurn's abandonment of conventional morality complicates Oates' claim that the Gothic quintet engages with the real and explores genuine historical injustices. ${ }^{127}$ Much as the novel makes efforts to represent historical wrongs, it often strikes a very peculiar tone in doing so. For instance, this is how we learn of the plight of Hortense, the second Mrs Kilgarvan:

Miss Hortense Spies... so sweetly docile, so unfailingly devout a young Christian woman, who in her virgin artlessness had rejected, it was said, any number of gentlemen her own age, as they seemed insufficiently "fired by idealism," - she of the full soft bosom and hips, the wavy chestnut-red hair, the childlike addiction to

\footnotetext{
${ }^{124}$ Oates, Winterthurn 471.

${ }^{125}$ Oates, Winterthurn 396.

${ }^{126}$ Friedrich Nietzsche, Beyond Good and Evil: Prelude to a Philosophy of the Future, trans. Helen Zimmern (Edinburgh: T.N. Foulis, 1909) 97.

${ }^{127}$ Oates, "Afterword (1985 Edition)."
} 
comfits... shading, alas, by degrees into a slovenly attired harridan with bruised eyes, her fair skin raked by her own nails, her manner oscillating betwixt a leaden despondency and a shrill shrieking hysteria... Dr. Hatch, finding evidence of fresh bruises, scratches, and cuts on those parts of his patient's body it was his professional duty to examine, confessed himself perplexed by the situation, for, it seems, the young Mrs. Kilgarvan had taken to punishing herself, even to the point of whipping her soft body with a riding crop! which morbid practice, she had dully explained, "was nothing more than she deserved: being foul, sinful, and of no more worth than a piece of barnyard filth.” Dr. Hatch firmly demurred; pointing out to the wretched woman that so mistreating her body, and thereby rendering herself ill-suited for the solemn duties of wifehood and motherhood, was in itself a sin, and must displease God greatly: whereupon the patient began to sob... and her husband, who had been pacing nearby... fell of a sudden into such despondency, he began to shout and curse at her... ${ }^{128}$

It is hard to miss the critique of nineteenth century mores and their facilitation of institutionalised patriarchal violence. It is easy to grasp the central irony of the passage, yet the number of voices Oates orchestrates to create this effect complicates it.

The narrator is ostensibly the editor of the mysteries, although in passages like this one, he or she appears to have access to an unusually wide variety of sources of information. The editor is able to attribute the story of Hortense's rejection of her earlier suitors, we presume, to community gossip, suggested by the editor's observation that 'it was said' she had turned the men away. At the same time, the editor is able to dramatically recreate the very private scene of Hortense's examination by Dr Hatch, describing the action of the characters and even Hortense's speech, events that could only be known to a limited number of people. The conceit of 'editorship' is strained here. The narrative voice is simultaneously an individual and

\footnotetext{
${ }^{128}$ Oates, Winterthurn 44-5.
} 
the voice of a community, encompassing many views. The editor frequently does emerge as an idiosyncratic character, although often this is used as a way to emphasise received nineteenth century fin de siècle values.

The narrator does not question Hatch's ludicrous diagnosis, although it is so wrong as to be blackly funny. Rather than ironically questioning the awful conspiracy of silence enforced by Erasmus and Hatch, the narrator is complicit in maintaining it, even as the contemporary reader questions it. Consequently, the reader is encouraged to take on the role that readers always do in detective fiction: we become the detective.

Unlike the irrational and insoluble problems that Xavier confronts throughout Mysteries of Winterthurn, the problem that confronts the reader is easy to resolve Erasmus has viciously abused Hortense. Her voice is reported as saying that she is foul, sinful, filth, but really it is Erasmus' disciplinarian voice that is enfolded in her speech, which is in turn carried to us through the narrator's voice. What begins to complicate the reading here is that one of the pleasures available when reading detective fiction is 'out-thinking' the narrative, discovering that one is right in one's suppositions. Here we have the pleasure of seeing through the falsehoods offered to us by the editor, Hatch, Erasmus and even poor Hortense; but this is a dubious pleasure indeed, revealing a degree of abuse that can hardly be amusing.

Hortense elicits the reader's sympathy, but the text imposes limits on the extent of that sympathy. The first and most significant limitation is that Hortense is a minor character, more important as a way of establishing the monstrousness of Erasmus than as an independent figure. Hortense is incidental, a detail of the novel's psychic landscape rather than its action. Likewise, although the reader is encouraged to read counter to the version of events given by the narrator, Hortense is still described in terms which are unlikely to render her as especially sympathetic. A 'sweetly docile' and 'unfailingly devout... young Christian woman' who rejects suitors for their lack of 'idealism' is too prissy to appeal to readers of a text that prefers to celebrate the murderous Perdita. Oates raises Hortense's situation, but then fails to take it seriously.

A further complication emerges in the prurient way in which Hortense's beauty and injuries are described. The narrator approaches Hortense in a way that might be endorsed by Dr Hatch, directing the reader's attention to 'those parts of his patient's body it was his professional duty to examine'. There is more than a hint of 
innuendo, and, reading against the narrator's claim, we see the doctor as a co-abuser, again protected by his profession.

Dr Hatch prescribes a course of treatments that are as gleefully sadistic as they are inefficacious. He confides to an acquaintance at the Corinthian Club, that he cannot understand Hortense's transformation

save in terms of an hereditary malaise, in virulent union with female pathology of an undefined sort. Nor did his customary methods of treating such disorders, involving vinegar douches, vigorous daily purges, - by way of Epsom salts, laxatives, and cold-water enemas - and bloodletting, - by way of a rare subspecies of leech affixed to the female genitalia - appear to be having much salutary effect. ${ }^{129}$

The doctor is puzzled, but we are not; we recognise Hatch's treatment as worthless and injurious, and that his doctorly ethics are hopelessly compromised by his priggish Club mentality. Our ability to detect the 'real' scenario is affirmed, but this merely confirms our view of the incompetence and sexism of nineteenth century medicine. The abuse Hortense suffers carries something of the weight of the real, but the narrator's spry tone gives it an appalling comic quality. It is not just leeches that torment Hortense, but a rare subspecies of leech. Although the image presented is unsettling, it is mitigated by an emphasis on the absurdity of the practice. The passage horrifies, but it does considerably more than just horrify. By involving comedy with horror, the seriousness of Hortense's situation is lessened. The text presents 'real world' abuse, but presents it as entertainment. This undermines Oates' attempts to have Winterthurn function as a polemic female Gothic.

Because the abuse of Hortense entertains as much as it appals, it becomes difficult to tell if we are to read her as a representation of a victim of 'real' violence, or as something else, a figure that has more to do with romance than realism. This ambiguity both reinforces and problematizes the sadomasochistic frisson present in the quoted passages. Hortense has been raked by nails, and her 'soft body' has been

\footnotetext{
${ }^{129}$ Oates, Winterthurn 45.
} 
whipped with a riding crop; this is as consistent with sadomasochistic practice as it is with abuse. It might even be possible to read Dr Hatch's archaic treatments in this context. If the text were interested in only presenting historical abuse, then why consistently frame it in terms which emphasise not just the gendered nature of Hortense's treatment, but its sexualised nature too, and divest it of its horror by emphasising its playfulness, its comedy? Is this a depiction of real abuse, a sadomasochistic fantasy, or a joke?

In $I t$, Beverly frantically battles to exit the house so she can escape her abusive husband, Tom. ${ }^{130}$ The scene is entirely conventional, both in its staging and its moral; it demonstrates that Tom is violent and cruel, and Beverly must leave him. It touches on the debilitating psychology of victimhood, but is hardly as complex as Oates's depiction of Hortense. Nevertheless, by presenting a conventional view of the scene, King achieves things that Oates does not. By reducing the complexity of his representation of domestic abuse, King clearly underlines the moral position of his text. By placing this violence at the centre of the chapter's narrative, rendering it in an earnest manner, It directs readers to the fact of domestic abuse, while retaining its immersive quality as a text. At the same time, the abuse Beverly suffers is not the carnival violence that occurs on 'The Raft' or the phantasmagoric menace of It's child-mutilating forms; the tone is distinct. King maintains distinctions between these heavily and lightly mimetic forms of violence. On the one hand, all of this means that King's readers do not have to take responsibility for engaging with the moral problematic of Beverly's relationship themselves, as this has already been determined for them; on the other, clarity can be a political virtue. Tom's assault on Beverly is not entertaining in the way that Randy's death on the raft is.

By contrast, Winterthurn often operates inside an ambiguous space, seeming to make the polemic gestures familiar from contemporary theorisations of the female Gothic, yet simultaneously undermining these gestures. Outside of Oates' afterwords, there is nothing in the text itself which signals how seriously we ought to take this material. Oates' text weirdly recalls Gilbert and Gubar's tone-deaf readings of Northanger Abbey, unable to identify how jokes function inside Gothic practice.

\footnotetext{
${ }^{130}$ King, It 111-30.
} 
This difficulty of tone and seriousness becomes even more troubling when we consider Oates' source material. Each of the narratives has some real precursor, and Oates claims the 'fictional cases are meant to bear a sort of dreamlike (or nightmarelike) relationship to the originals. ${ }^{, 131}$ Even this claim is oblique and teasing, as she does not divulge the historic events referred to, but nevertheless appropriates the authority of history for her text. 'The Virgin in the Rose-Bower' is drawn from a newspaper report about the discovery of some mummified foetuses; the lynching of Rosenwald in 'Devil's Half-Acre' is based on the public murder of Leo Frank at the hands of a Klan precursor in 1915, and presumably something like the Jack the Ripper murders; and 'The Bloodstained Bridal Gown' bears similarities to the Lizzie Borden and Hall-Mills murder cases. ${ }^{132}$

We are happy enough to read about axe murder in the Gothic text; indeed, axe murder is exactly the sort of thing we hope to read about when we pick up a Gothic. However, anti-Semitic lynchings, spousal abuse and so forth hold a different quality, carrying the charge of the real. An interesting distinction to make here is that a joke about axe murder is not necessarily going to be offensive to most people; a joke made about lynching or spousal abuse is far more likely to offend. While some of the violence that Winterthurn depicts is usually treated as 'serious', and seems to carry a political and emotional charge, other instances of violence in the text are comparatively much less disturbing, even carnivalesque. It is impossible to read Rosenwald's death as anything other than terrible, yet Perdita's murder of three people is loaded with very little opprobrium, and even apparently aligns itself with the loosely feminist agenda of the text. Where King carefully separates mimetic violence that refers to the real from the Gothic's carnivals of cruelty, Oates does not make this distinction. This lack of clarity demands that readers adopt literary rather than Gothic reading practices to negotiate Winterthurn's complexities.

\footnotetext{
${ }^{131}$ Oates, "Afterword (1985 Edition)."

${ }^{132}$ Creighton, 48. For further information on the death of Franks, and the Hall-Mills and Borden murders, see Nancy MacLean, Behind the Mask of Chivalry: The Making of the Second Ku Klux Klan (New York: Oxford UP, 1994) 12; Victoria Lincoln, A Private Disgrace: Lizzie Borden by Daylight (London: Gollancz, 1968); William M. Kunstler, The Minister and the Choir Singer: The Hall-Mills Murder Case (London: Panther, 1967). I have been unable to identify the source of the foetus story.
} 
Oates describes her quintet as '(post-Modernist) Gothic novels', ${ }^{133}$ and in examining why a 'serious writer' such as herself would engage with genre, she ponders, 'why choose such severe restraints, such deliberately confining structures?' before describing genre as a 'formal discipline' that causes a 'radical re-visioning of the world and of the craft of fiction'. ${ }^{134}$ Oates misrecognises genre as a 'severe restraint' and a group of 'structures' rather than as the set of practices that permit a particular game to be played; genre is couched as a problem rather than a shared and enabling set of methods. If the Gothic genre can be described by the notion of habitus, then it is a practice which, despite the playful modulations of the media in which it appears, will, when it is successfully performed, retain a core of experience and practice, a coherence not radically altered by the emergence of a literary practice like postmodernism. This, however, is not to say that postmodernism is not capable of disrupting Gothic performances to such an extent that they become ineffectual. Oates' phrasing suggests that a postmodernist Gothic is an unproblematic conflation, but when she uses postmodern literary practices to rearrange the Gothic, she creates substantial incoherence in her text; her postmodern turns are not a refreshening modulation of a genre, but an elitist misunderstanding of it. Mysteries of Winterthurn, in common with the rest of the published novels of the Gothic quintet, offers only the pleasures of literary fiction rather than the pleasures of the genres; it is a literary pastiche rather than a performance of a popular practice.

\section{Beloved}

Given the problems attending Mysteries of Winterthurn's blending of Gothic and literary practices, Toni Morrison's Beloved presents an interesting counterpoint. Like Winterthurn, Beloved is a clearly literary work that involves itself in Gothic practice. Unlike Oates' novel, however, Beloved manages its simultaneous performances more carefully. The novel embraces a fragmented, postmodern style, that many readers might find difficult, but has nevertheless achieved bestselling success. It engages in

\footnotetext{
${ }^{133}$ Oates, "Author's Afterword (2007 Edition)."

${ }^{134}$ Oates, "Afterword (1985 Edition)."
} 
the complex, often distressing discourses of African American slavery, material that requires the care and seriousness of literary practice, but often veers into the Gothic's cruel grotesque. Despite its self-consciously difficult style and material, unlike Winterthurn, when Beloved engages with the Gothic, it does so in a more successful, coherent fashion. ${ }^{135}$

Beloved centres on Sethe, a fugitive slave who has escaped from the Sweet Home farmstead in Kentucky, and settled in Cincinnati. As with It, the action occurs mainly across two timeframes, in this case the mid-eighteen-fifties and the mideighteen-seventies. The novel gradually reveals the disastrous details of the largely failed escape attempt from Sweet Home in the eighteen-fifties, and the haunting of Sethe in the eighteen-seventies. It emerges that the ghost-made-flesh that haunts her is Beloved, her own child, who Sethe killed when she was traced and confronted by her former owner, the monstrously cruel 'schoolteacher'. The rationale given for the killing is that Sethe would rather her child die than endure the conditions of slavery. While the act causes schoolteacher to give up his ownership of Sethe, so that her freedom is guaranteed after her time in jail, it also motivates the dead child to return. Beloved becomes malignant by gradual degrees, pushing Sethe into delirium. Her living child, the painfully shy Denver, must support her strange family until the women of Cincinnati's black community exorcise the ghost. The story is told in looping narrative arcs, a mesh of tale and remembrance, or as the text describes it, 'rememory'. The narrative mode is every bit as complex as Winterthurn, although the story being related is much simpler.

This brief synopsis should suggest that Beloved is involved in discourses of race, performing precisely as Gothic studies claims the American Gothic ought. It is, however, worth noting this particular critical belief emerged in the wake of Beloved's publication and success. Without a firm grasp on the Gothic itself as a historical phenomenon, it is easy to mistake contemporary variations on the genre for more permanent arrangements. In particular, Edwards' and Goddu's arguments, which posit the Gothic as an engagement with history, and especially African American history and slave narratives, can be understood as reading Beloved back into earlier texts.

\footnotetext{
${ }^{135}$ I have limited my discussion here to Beloved's involvement in literature and the Gothic. Others have explored its involvement in distinct African American genres. See Madhu Dubey, "The Politics of Genre in Beloved," NOVEL: A Forum on Fiction 32.2 (1999) 187-206.
} 
Nevertheless, this also suggests the powerful status of Beloved, which has contributed to the reshaping of critical understandings of the genre.

There is no doubt that the text has been extraordinarily successful. Although there was consternation when the novel failed to take the 1987 National Book Award for fiction, ${ }^{136}$ Beloved was later awarded a Pulitzer. In fact, this was a prize that Morrison actively lobbied for, framing her campaign in terms that constructed the prize itself as holding a racist bias, while simultaneously insisting it held real canonforming value; famously, forty-eight black littérateurs signed an open letter to the New York Times Book Review demanding that Morrison be given the recognition of an award. ${ }^{137}$ By claiming the Pulitzer, Morrison symbolically refigured the prize itself, becoming the live black woman who answered those bugbears of the eighties, the dead white men of the canon. At the same time, the Pulitzer confirms the novel's status as genuinely literary, although, as James F. English argues, 'prize-winning' is not necessarily the same thing as 'elite' within the bounds of the cultural field. ${ }^{138}$

In addition to the prestige the text accumulated, Beloved was also a bestseller that sold 'stunning' quantities in trade paperback, a format largely limited to specialist booksellers and thought to appeal to 'a more affluent audience'. Unusually, it was concurrently produced in a mass-market paperback edition, available in 'airports, supermarkets and cigar stores. ${ }^{139}$ While it is one of the few Morrison books not promoted through Oprah Winfrey's Book Club, it has, of course, benefited from having Winfrey produce and star in the 1998 film it was made into. John Young discusses the position occupied by Morrison's work, and in particular her ongoing relationship with Winfrey, essentially a marketing arrangement, arguing that by 'constructing an audience built through popular, ostensibly low, culture for her serious novels, Morrison explodes the high-low divide that still holds for much of

\footnotetext{
${ }^{136}$ Michiko Kakutani, "Did Paco's Story Deserve Its Award?" New York Times 16 November 1987, late ed.: C15.

${ }^{137}$ James F. English, The Economy of Prestige: Prizes, Awards, and the Circulation of Cultural Value (Cambridge, MA: Harvard UP, 2005) 237-45.

${ }^{138}$ English.

${ }^{139}$ Edwin McDowell, "Publisher's Gamble: One Book, Two Types of Paperback," New York Times 28 January 1991, late ed.: C18.
} 
postmodern art. ${ }^{140}$ This reading of Beloved as a media event as much as a text suggests that it achieves what Winterthurn fails to do, successfully bringing together elite and demotic cultures.

The publication of Beloved cemented Morrison's entry into the literary canon; English, not entirely enthusiastically, suggests that 'today, one must regard Morrison as America's most esteemed novelist, and Beloved as her most indispensable book' ${ }^{141}$ Despite the extent of Morrison's success, there remain sceptics. Unlike Oates and King, who have no shortage of public detractors, Morrison's position in the literary field is apparently almost unassailable, at least officially. However, Craig Seligman offers another perspective when he writes

Toni Morrison doesn’t have admirers, she has believers. Critics compelled to say something less than glowing about one of her books wince at the pettiness of noting cracks in the mountains, as though they might as well be knocking Shakespeare... She has no detractors - or at least so it might seem if you've never been at a literary dinner party where mention of her brought howls and groans: "Toni Morrison?" It's jarring to hear an author about whom next to nothing unkind has been written dismissed so fliply: "Who can read her?"142

The distinction is that one admires literature, rather than believing in it. Seligman's difference between admirers and believers is a telling one, and suggests that Morrison's oeuvre is being used by her supporters in a way that is not properly literary. Belief here suggests a non-literary, unacademic engagement with her texts. Seligman's dinner-party guests do not read Morrison because her writing is not for admirers such as themselves. However, it seems that Morrison's position within the

\footnotetext{
${ }^{140}$ John Young, "Toni Morrison, Oprah Winfrey, and Postmodern Popular Audiences," African American Review 35.2 (2001): 182.

${ }^{141}$ English 239.

${ }^{142}$ Craig Seligman, "Toni Morrison," rev. of Jazz and Playing in the Dark: Whiteness and the Literary Imagination, by Toni Morrison, The Threepenny Review 52 (1993): 7.
} 
literary field is such that objections must be raised in private, rather than entering into the discursive space of publication. The reason for this, more than Morrison's prestige, is her race, more specifically, her position as a champion of African American culture. As the living black woman thought to be able to contest the prejudices entangled in the works of all those dead white men, it is easy to see how even well-intentioned criticism of Morrison's literary prowess might appear as politically retrograde. Morrison's political power lies in the cultural capital she is accorded. An odd disconnect occurs here, where critical judgements of her literary production, the basis of that capital, are, if Seligman's account is to be believed, publicly withheld as a political necessity.

Seligman notes that one of the few prepared to attack Beloved on its publication was Stanley Crouch, an African American critic. Crouch's withering review makes two principal objections to the novel. He picks up on the statement the novel makes in the space where a dedication might more usually appear; 'Sixty Million and more', a dedication to lost slaves, which, of course, also recalls the approximate number of Jews murdered in the Holocaust, although Morrison multiplies that figure by ten. ${ }^{143}$ Crouch seethes:

Beloved, above all else, is a blackface holocaust novel... written in order to enter American slavery into the big-time martyr ratings contest, a contest usually won by references to, and works about, the experience of Jews at the hands of Nazis. ${ }^{144}$

Crouch's second concern relates directly to the novel's status as literature. While acknowledging that Morrison is a talented writer, he finds Beloved to be 'protest pulp fiction', 'a melodrama lashed to the structural conceits of the miniseries', stuffed with pat homilies and gooey sentiment. He concludes that, despite Morrison's disavowal of her own nationality, she is 'as American as P.T. Barnum., 145

\footnotetext{
${ }^{143}$ Toni Morrison, Beloved (1987; London: Vintage, 2005) n.pag.

${ }^{144}$ Stanley Crouch, "Aunt Medea," Notes of a Hanging Judge (New York: Oxford UP, 1990) 205.

${ }^{145}$ Crouch 206, 209.
} 
For Crouch, Morrison's success and position in the field are symptoms of what is for him a wider discursive problem, but his criticism remains interesting. Like Seligman's dinner party critics, Crouch is unconvinced that Morrison is producing literature in the valorised sense. Morrison 'lacks a true sense of the tragic.' ${ }^{146}$ Instead, it is a 'pulp fiction'. Miniseries are for the masses. Homily and sentiment are middlebrow crowd-pleasers. This strand of Crouch's critique attacks Morrison for producing a potentially popular work; yet all of these elements suggest that Beloved, despite its fragmented style, might afford readers the opportunity for the immersed, affective reading experience typical of popular literature and the Gothic.

Crouch also attacks the authenticity of Beloved; it is a blackface show, a melodrama, a circus performance worthy of Barnum himself. These are popular, spectacular rather than mimetic forms; like the Gothic, they are entertainments, and their ability to tell us the truth is not what they are valued for. For Crouch, unsurprisingly, these are inappropriate ways to deal with the real horrors of slavery. The term 'blackface holocaust' is especially interesting in terms of whether or not we ought to frame the text as a Gothic. If the Gothic actually dealt with all the 'Other', abject, traumatic things that some critics believe it does, we would be overwhelmed with Gothic texts set in Hitler's death camps. Fortunately, we are not. Were we to read of this kind of suffering, described in the terms and tones that the Gothic uses, where violence can be a form of entertainment, we would quite rightly be appalled. In King's terms, the atrocities of the Holocaust are not especially useful 'natural ingredients' for the Gothic, as they demand a seriousness and reference to the real that would stymie the Gothic's playful need for excess and escape. This is not to preclude the possibility of such a text, only to suggest that we do not have a substantial number of them, and that there is a reason for this.

Some genres are basically immiscible, and Crouch's assessment of the novel suggests that this is the problem with Beloved. His critique does not explicitly label the text a Gothic, but really, he is arguing that it is something like the Gothic, and the concerns he raises relate to characteristics typical of the contemporary Gothic: pulpiness, melodrama, a carnivalesque performativity. His objection is that the Gothic

\footnotetext{
${ }^{146}$ Crouch 205.
} 
is an inappropriate form in which to explore the disaster of American slavery. Is the novel literature or something else, a more explicitly popular practice?

This uncertainty is demonstrated in Ann Snitow's review of the novel for The Village Voice Literary Supplement, where she expresses concerns about the central role played by Beloved as a character and metaphor. Snitow worries Beloved is too lifeless, too abstract, and fails to symbolise what she ought to, and then suggests that 'Usually in contemporary fiction, the grotesque is mixed with irony or zaniness, not with passion and romance. Morrison rejects irony, a choice that immediately sets her apart. ${ }^{147}$ As a practice, the Gothic tends towards the immersive moment rather than ironic reflection. This sets Morrison's text apart from Oates's problematic Gothic. Where Oates demands her reader assume a distanced, even alienated position, for Beloved to function, readers need to emotionally engage with Sethe. This is intended as an intense reading experience, although Crouch objects to the melodrama and sentimentality that achieves this intensity.

While Snitow notes the passion and romance of the text, which is to say its affective and involving nature, by placing Morrison inside the frame of 'contemporary fiction', a synonym for literature, she misses that Morrison has actually aligned herself with King's earnestness. Without unambiguously labelling the text as a Gothic, Snitow identifies the text as grotesque and suggests a reading strategy, familiar from the contemporary Gothic, together with a problem that might emerge in deploying that reading strategy, to wit, the depiction of Beloved herself. Snitow's reading suggests that the novel is a Gothic, but one that fails to present a satisfactory ghost.

However, Snitow later altered her assessment of the text. In a note accompanying an anthologised reprint of her review, she writes:

I criticized Morrison for writing a clunky ghost, but maybe the one taking that ghost too literally was myself... We never get half a chance to love Beloved, and her name becomes a pure and bitter

\footnotetext{
${ }^{147}$ Ann Snitow, rev. of Beloved, by Toni Morrison, Toni Morrison: Critical Perspectives Past and Present, eds. Henry Louis Gates Jr., and K. A. Appiah (New York: Amistad, 1993) 29.
} 
irony, an irony which tempers every bit of Morrison's romanticism. ${ }^{148}$

This might be an act of critical capitulation and contrition in the face of a book that has acquired such prestige that it is no longer tenable for Snitow to maintain her earlier judgement. However, this revision also suggests a shift in reading strategies. Snitow abandons her initial assessment of the ghost at the same time she abandons her reading of the text as non-ironic. If an abstract irony makes a poor ghost to place in the middle of a Gothic, it creates no problem in a work of literature. Snitow's reconsideration reordinates the genres in the text, emphasising the work's value as literature over its value as a Gothic; her first reading raised concerns that might trouble the romantic or Gothic reader, while her second drives towards a literary interpretation. The critic shifts between one mode of reading and another. Snitow simply misrecognises the outcomes of different reading strategies as interpretations rather than options. In fact, Beloved is a text that requires both Gothic and literary reading strategies, and to successfully engage with the text, readers need to shift between these two modes, sometimes quite rapidly.

Morrison employs a purposely oblique narrative style intended to challenge readers. Beloved begins in a disorienting fashion, but immediately marks itself with the paraphernalia of the Gothic:

124 was spiteful. Full of a baby's venom. The women in the house knew it and so did the children. For years each had put up with the spite in his own way, but by 1873 Sethe and her daughter Denver were its only victims. The grandmother, Baby Suggs, was dead, and the sons, Howard and Buglar, had run away by the time they were thirteen years old - as soon as merely looking in a mirror shattered it (that was the signal for Buglar); as soon as two tiny hand prints appeared in the cake (that was it for Howard). ${ }^{149}$

\footnotetext{
${ }^{148}$ Snitow 26 n.

${ }^{149}$ Morrison, Beloved 3.
} 
Over the next couple of pages, we experience further signs of the haunting, details of Howard and Buglar's flight, thoughts about winter in the relatively new state of Ohio, Baby Suggs' death and her love of simply staring at colours, and more. Readers are confronted with a mass of information, without sufficient context to bring it together into a coherent, representational whole. What is 124 ? (The address of the house). What sorts of people are these? (Slaves, now free). What is happening? (The house is being haunted and the family is fragmenting). Is this Baby Suggs, the baby who is haunting the house? (No; she is the mother of Sethe's dead husband, although the text is initially not just obscure but deliberately misleading about this distinction). The answers to these questions come later.

Remembering that Morrison is a Faulkner scholar, we can see Beloved's opening echoes the first part of The Sound and the Fury, without being quite so radical. Faulkner's simpleton, Benjy, has limited perceptive and reflective powers, which leaves his readers struggling to make meaning. Morrison's opening demands the text be read as literature; readers must work through the text carefully, reflectively, as if trying to assemble something that is broken. This is not the opportunity for untroubled immersion typical of popular fictional modes.

However, we are also reading the typically Gothic: a malevolent ghost, shattered mirrors, eerie traces of the dead's agency. We are baffled and removed from the immediacy of the actions depicted, but also presented with something more familiar - a haunting. We might not understand the details of the action teasingly presented, but the familiar Gothic trope, a haunted house, is offered. It is recognisable, a consolation, the beginning of a reading. Morrison's opening depicts events that disquiet Sethe's family while plunging readers into interpretive disorientation; events in the text are echoed in the reading experience. The paradox is that readers can gain some kind of surety about what the text is depicting by fixing on the thing, the haunting, that creates the disorientation.

Even in its first five sentences, Beloved signals to readers that it is involved in both literature and the Gothic, and uses these two practices in separate yet complementary ways. Readers are pushed into a literary reading strategy, while being led through a difficult passage by a distinctly Gothic trope. This kind of deft oscillation between frames of reference is frequently required in the novel as rememory follows rememory. 
Another instance of this technique appears early in the narrative when Sethe pays for the inscription of her daughter's tombstone with the word 'Beloved' by having sex with the engraver:

The welcoming cool of unchiselled headstones; the one she selected to lean against on tiptoe, her knees wide open as any grave. Pink as a fingernail it was, and sprinkled with glittering chips. Ten minutes, he said. You got ten minutes I'll do it for free... She thought it would be enough, rutting among the headstones with the engraver, his young son looking on, the anger on his face so old; the appetite in it quite new. ${ }^{150}$

As is typical in Beloved, the scene conveys a lot of information briskly. We learn where the name 'Beloved' comes from, literally a memorial as much as a name. Sethe's love for her dead daughter is made visible, as are her guilt and distress. Sethe may be free, but the engraver, presumably white, is happy to use the former slave's body as a commodity. The engraver's son is interested in the sexual act he views, but anger remains in his gaze; is this racist prejudice or something more specific, disgust for Sethe's act of infanticide? The second interpretation is not available at first reading, but relies on readers returning to the passage once they have assembled the story. Considering what, exactly, motivates this gaze, it becomes harder to separate the violent structures of slavery and racism from Sethe's murderous act, and, indeed, from the sexual act she is then engaged in. The persistent effects of slavery are dramatised in a particular instance.

The density of ideas held in the passage requires a careful, literary reading practice. At the same time, it is hard to miss that Sethe is having sex on a tombstone, 'her knees wide open as any grave'. This is hardly a subtle image, sexualised and deathly, the connection being drawn between the womb and the tomb hackneyed, the schlocky shock-stuff of the Gothic. Crouch is right; moments like this are melodrama rather than simple mimesis. However, what is interesting here is how quickly Morrison shifts between the things native to the Gothic ('rutting amongst the

\footnotetext{
${ }^{150}$ Morrison, Beloved 5.
} 
headstones') and those native to literary practice (the transformation of 'young' to 'old' to 'new' within the engraver's son).

Within this brief passage, Morrison directs readers away from the appalling and then back towards it again. No sooner do we see Sethe on the headstone than we are directed towards the quality of the stone itself, described in terms that make it seem pretty, even capable of human touch. We are distanced from the immediacy of the situation through the image of the fingernail, a literary, metaphoric turn. From there we are directed to the unpleasant power dynamic between the characters. 'Ten minutes', demands the engraver. The man is a quick sketch, an incidental villain, Sethe his victim; yet surely she must have approached him with this proposal, needing to degrade herself in an attempt to expiate her guilt; rutting, after all, is animal sexuality, not human. Humanness leaches out of the scenario, a turn both Gothic and literary.

The engraver is typical of many characters in Beloved, in that his ability to inflict abuse is more important than the depiction of motive for that abuse. Morrison's decision to reduce the mimetic depth of many of her characters troubles Crouch, who feels she refuses to engage with the human complexity of the situations she presents. ${ }^{151}$ In Morrison's defence, popular genres frequently draw on the romance, encouraging their readers to invest their interest in a particular character or characters, as a stake in the game of the narrative. A corollary is that other characters in the romance will be less developed, and readers are invested against them. There are goodies and baddies, and readers relate differently to these figures, although this relationship is sometimes complicated or even reversed in the Gothic. Nevertheless, in the romance, it is often enough for baddies to simply be wicked. When we read The Scarlet Letter, we do not complain that Chillingworth is not a little more fleshed out. This potentially reduces the discursive complexity of romance texts, but is likely to trouble only those readers who require these texts to perform as something other than romances.

Yet Crouch's objection remains: can we ever work through American slavery in simplified, populist, even blockbuster formats? Beloved attempts exactly that. It is a popular romance, but it is also a literary novel about slavery. It is hardly surprising

\footnotetext{
${ }^{151}$ Crouch 205-6.
} 
there is an unresolved tension in the orchestration of these dual functions. Crouch assumes that certain material can only be properly dealt with in elitist forms. This is intended as an argument for a sufficiently sophisticated style of engagement, but it is also an argument against a popular audience. The corollary of claiming that American slavery ought not to be discussed in a middlebrow form is that middlebrow readers ought not to engage with this discourse. These readers might not be as talented at parsing texts and passing judgement as cultural capitalists like Crouch, but to dismiss this audience entirely is dangerously snobbish position-taking.

Although a tension between the Gothic's schlock and the complexities of literature is present in the text, Beloved succeeds. This tension is evident in the opening, and in Sethe's encounter with the engraver. In a wider sense, it is present in the narrative arrangement of the novel, which, while consciously literary in its fragmentation, still functions as Gothic narratives do, promising dreadful action, but delaying its arrival. Beloved's narrative loops diffuse the action of the story throughout the text. The event that lies at the centre of the story, Sethe's act of infanticide, repeats and resounds in slow motion. Readers are submerged in its echoing consequence, without perceiving the event itself. Nevertheless, most will have assembled a sense of the infanticide some time before the event is substantially depicted; we first learn that a baby has had its throat cut on the novel's fourth page. The killing itself is teasingly held back, in typical Gothic fashion, so that readers proceed almost processionally towards the worst that the book has to offer. It is only two-fifths of the way through the narrative that Nelson Lord asks Denver about her mother being a murderer; and even then, the substance of the question is withheld for two pages, as we instead read that Denver becomes hysterically deaf when she hears Sethe answer the question. Her mother's response is obscured. Details of the killing are withheld for a further fifth of the text. ${ }^{152}$

Unlike the bulk of the novel, which is told from the perspective of the former slaves Sethe, Paul D, Denver and even Beloved, the fatal scene is presented from the perspective of the slave hunting party, in particular, schoolteacher, although the narrative voice seems to include perceptions and memories held by some of the others. The speaker is not a single man, but the voice of the group. However, this

\footnotetext{
${ }^{152}$ Morrison, Beloved 6, 50, 121-3, 174-7.
} 
voice is modified by the names it uses to describe these characters; 'Nephew', 'schoolteacher'. These are not the appellations that the group itself uses, but the distancing identifiers used by the slaves themselves. This is a slightly awkward modification of the voice, but it depersonalises these figures; just as Stamp Paid, Baby Suggs, Sethe and her children are only 'niggers' to the white men, so too are the identities of the white men undermined through their relationship to the slaves.

It is not just schoolteacher's identity that is absent; it is anything resembling a human reaction to the scene too. He looks at Sethe, her bleeding dead baby in her arms, that blood covering Howard and Buglar, and as Sethe stares at him, reflects that 'something was wrong with her... if his other nephew could see that look he would learn the lesson for sure: you just can't mishandle creatures and expect success. ${ }^{153}$ The observation that something is wrong with Sethe is absurdist understatement. Nephew, at least, is shaken, whereas schoolteacher only worries about who will now help make the ink and press his collars. Schoolteacher is no more the mimesis of a human being than It's escaped lunatic Henry Bowers, or his sometime companion, Patrick Hockstetter, who has killed his brother and keeps dead things in a fridge at the dump. This particular villain may be written in a slightly more sophisticated register, but like King's monsters, schoolteacher is not so much a human as a baddie. This sort of variation in depth of representation finds Beloved straddling literature, where the presentation of human experience is valued, and the Gothic, where a simply evil villain can usefully facilitate the genre's horrors. Morrison flattens the moral problematics of the narrative; she is interested in the shades of right and wrong played out in Sethe's predicament, but schoolteacher is, by contrast, an unambiguous and absolute evil, presented in the terms the contemporary Gothic reserved for irredeemable madmen and serial killers.

The difference between schoolteacher and Henry and Patrick is that as much as being a character, he represents a crystallisation of the ideology that facilitates slavery, in much the same way that Beloved can be read as the manifestation of Sethe's trauma. Henry and Patrick are only the agents of It. Schoolteacher carries the charge of the real; readers know that this fictional account is more than fictionally true, as it relates to historical violence. This knowledge is confirmed for readers when

\footnotetext{
${ }^{153}$ Morrison, Beloved 176.
} 
Morrison notes in her foreword that Sethe's action is based on the case of Margaret Garner, an escaped slave who killed her child for similar reasons. Where It often directs readers away from the real, Beloved, like Winterthurn, encourages readers to connect the text with history.

However, as much as the scene of infanticide carries the charge of the real, of the moment when Margaret Garner took her own child's life, it also bleeds into the unreal. Nephew looks on as Sethe's eyes change, 'Since the whites in them had disappeared and since they were black as her skin, she looked blind. ${ }^{154}$ The image is arresting, strange, awful, a female Oedipus as much as Medea, blinded and bloody. Recalling that this is the sort of text where ghosts appear as human and red lights flicker around old houses, we take it as a literal account of the scene rather than poetic hyperbole. Although the infanticide points to historic violence, it also gestures away from it, shifting the killing onto a different ontological plane, occupying the space of folktale or legend rather than realism. Madhu Dubey's reading is useful here, arguing that the novel's blend of the supernatural and the more recognisably real is indicative of a uniquely 'black cosmology. ${ }^{, 155}$ Dubey's reading gives a coherent account of the text, allowing for Beloved's strangeness; however, as much as this represents a distinct, African American way of seeing the world, it is also the stuff of horror movies.

The death of the child is typical of the way that horror is presented in Beloved. Sixo is burnt alive; 'His feet are cooking; the cloth of his trousers smokes. ${ }^{156}$ Halle is driven mad as he watches the gang rape of his wife. The infant Denver drinks the blood of Beloved, spilt on her mother's breast, when she is fed in the wake of the killing. Snakes menace Paul D while he is virtually buried alive, chained to a group of other slaves. Where writers like King are happy to describe gore in colourful terms, Morrison typically prefers to focus on the awful inventiveness of human cruelty. Morrison is aiming to appal, and historically authentic as this violence might be, it shades into Gothic guignol. This is not just violence; it is extraordinary violence, in the vein of shockers like 'The Pit and the Pendulum' or 'The Raft'. The difference is

\footnotetext{
${ }^{154}$ Morrison, Beloved 177.

155 Dubey 191.

${ }^{156}$ Morrison, Beloved 266.
} 
that, unlike 'The Raft', where violence is dissociated from the real and becomes a form of escapist entertainment, in Beloved, no matter how weirdly Gothic the brutalities depicted become, readers are unlikely to find uncomplicated entertainment in these scenes.

The pleasures of the Gothic are complicated to the point that they disappear in these instances. However, the novel provides other Gothic satisfactions. Margaret Atwood's review in The New York Times Book Review noted that 'the supernatural element is treated, not in an Amityville Horror, watch-me-make-your-flesh-creep mode, but with magnificent practicality, like the ghost of Catherine Earnshaw in Wuthering Heights'. Atwood goes on to say that 'Students of the supernatural will admire the way this twist is handled. Ms Morrison blends a knowledge of folklore... with a highly original treatment. ${ }^{, 157}$ Atwood values the work as literature, but describes its ghost as being of particular interest to a certain audience, marking it as a discrete pleasure. She admires the depiction of Beloved for its newness, displaying the kind of game-sense possessed by Gothic readers.

Of course, Beloved is not simply a Gothic in the way that a book like $I t$ is. For all its sadism, Beloved offers consolations too. Both food and sex are celebrated throughout the novel, whether this is the celebratory meal provided by the inhabitants of 124 at their party, or the sensual, in fact oddly sexualised corn enjoyed by the Sweet Home men after Sethe and Halle have consummated their marriage in the cornfield. Baby Suggs preaches on the pleasures of the body. ${ }^{158}$

While it does more than the Gothic needs to, Beloved is a savvy engagement with the field. The American Gothic of the later eighties and early nineties was interested in the 'mad' or serial killer as a villain-figure. ${ }^{159}$ Morrison's novel deftly

\footnotetext{
${ }^{157}$ Margaret Atwood, rev. of Beloved, by Toni Morrison, Toni Morrison: Critical Perspectives Past and Present, eds. Henry Louis Gates Jr. and K. A. Appiah, Amistad Literary Series (New York: Amistad, 1993) 33,35 .

${ }^{158}$ Morrison, Beloved 160-1, 32-3, 104.

${ }^{159}$ See for instance, Stephen King's Misery, Thomas Harris' The Silence of the Lambs, Brett Easton Ellis' American Psycho, Poppy Z. Brite's Exquisite Corpse, Joyce Carol Oates' Zombie, but especially any number of slasher films in the vein of 1984's A Nightmare on Elm Street, 1980's Friday the $13^{\text {th }}$ and 1978's Halloween.
} 
engages with both concerns. Schoolteacher is as terrible as any movie slasher, and the text is carefully structured around a set of horrifying set pieces.

However, by involving Beloved in literature at the same time as the Gothic, Morrison opens her text up to critiques that emerge from the tension created by the commingling of genres. For Atwood, these separate practices are reconcilable; for Crouch, they invalidate the text. This smudging of Gothic and literary practice is common enough in canonical literature, but because Morrison deploys it in a politically charged context, using Gothic strategies for polemic ends, it is hardly surprising it becomes a point of objection for critics like Crouch. Yet it is because Beloved participates in both the Gothic and literary practice that it became a resource for arguments made later, within Gothic studies, where depictions of slavery and the slave narrative became virtually synonymous with the American Gothic. However, looking to the novel within its originary context, we are reminded that Beloved was never a typical Gothic of the period, and as much as it is innovative, it also an outlier. While it has accumulated literary prestige, seemingly influencing the development of academic Gothic studies, it has not necessarily reconfigured the field itself.

\section{Conclusion: Headless Bride}

It, Mysteries of Winterthurn, and Beloved appeared within four years of each other, contemporaneous products of Reagan's America. However, despite their closeness in space (all of the writers resided in the Northeast) and time, the texts represent very different engagements with the Gothic. It, in many ways the archetypal horror blockbuster, represents a popular understanding of Gothic practice. Nevertheless, it engages with the postmodern zeitgeist, deconstructing its monster, but ultimately using this rearrangement for Gothic ends rather than genuinely forming a bridge between literary and popular cultures.

Winterthurn and Beloved both attempt to participate in the Gothic and literature with varying degrees of success. Oates' Gothic quintet, extending to some 2,600 pages, mimics the sheer length of the horror blockbuster popular at the time. Beloved, a much slimmer volume, nevertheless features a largeness of theme and a breadth of appeal that has something to do with the bigness of the blockbuster. 
The way that Oates uses the Gothic in Winterthurn seems to draw on Gilbert and Gubar's theorisation, where the genre becomes a tool with which to expose historic wrongs. However, Oates playfully rearranges the genre, a manoeuvre typical of literary postmodernism. She layers doublings upon doublings, introduces weird tonal quirks, and refuses to clarify the rules by which she plays the Gothic game. Oates introduces wry literary conceits, yet in disrupting the procedures of the Gothic, Oates succeeds in disrupting the sense of her own text. Beloved more successfully straddles the popular Gothic and the literary novel, but in doing so, has attracted critical concern over the immiscibility of these genres. This is a problem that, it seems, many of Morrison's readers have been able to negotiate for themselves.

These are texts that hold diverse interests. By reading them side-by-side, I have suggested that it is useful to think of Gothic practice as historically specific, but also that within that frame, individual texts will employ the Gothic in distinct ways. The Gothic is not an absolute state or category, and we need to consider the arrangement of the field and the texture of the particular instance when we study it. Another point that emerges from placing these texts alongside each other is that some texts will involve themselves in multiple genres and discourses, while others singlemindedly pursue the Gothic.

Genre ordination, the way in which readers, through habitus, instinctively recognise one practice within a text as more significant than another, is useful here. This ability to make distinctions correlates to our ability to succinctly judge what a text is 'about'. Any description of It would have to mention that it is about a group of childhood friends who battle a monster under the streets of Derry; it is unambiguously a Gothic. Whatever Winterthurn's complexities refer to, the difficulty we have in trying to articulate them suggests it is about an oblique literary practice before it is about anything else. Beloved might be about the aftermath of slavery or it might be about the haunting of a former slave; either description seems fair. That we could choose a thematic or a mimetic emphasis in describing the 'aboutness' of Beloved suggests the novel might be read as a work of literature especially interested in African American history, or as a ghost story.

The difference is demonstrated in a pair of passages from Morrison's text. Paul D relates a ghost that was thought to haunt the grounds of Sweet Home in better days: 
"Reminds me of that headless bride back behind Sweet

Home. Remember that Sethe? Used to roam them woods regular."

"How could I forget? Worrisome..."160

Headless brides are the stuff of folklore, of story, a comfortably familiar Gothic manifestation. A different view of haunting comes from Baby Suggs, who complains of a more general haunting, saying there is " Not a house in the country ain't packed to its rafters with some dead Negro's grief...", 161 A decapitated bride might be worrisome, but hardly relates to real dangers in the same way. Sometimes a ghost stands for historic atrocity; sometimes it is simply an entertainment.

For Gothic studies, the position of prestige that Beloved has claimed, even more than the text itself, has facilitated the development of arguments that conflate slave narratives and historic racism with the American Gothic in general. This has resulted in an emphasis apparent in some scholarship that is not reflected in the field itself, a desire to connect the genre to a historical America. While these critical attempts might not always hold up, it is worth noting that each of the three texts discussed in this chapter refer to America's past, whether that is the mid-to late nineteenth century of Beloved, the late nineteenth and early twentieth of Winterthurn, or the nineteen-fifties and the violent episodes which span back centuries in It. King, Oates and Morrison present the past as something like the 'old, weird America' that Greil Marcus postulates in Invisible Republic. This notional version of America has 'dissolv[ed] a known history of wars and elections into a sort of national dream, a flux of desire and punishment, sin and luck, joke and horror'. ${ }^{162}$ This is a past halfremembered, but half-imagined too, a historic real that is neither exactly historic nor real. These Gothics are contemporary texts which frame the past for their present needs, occasionally engaging with it in a potentially discursive mode, as with Baby Suggs' negro-haunted houses, but often simply using it as a source of the 'natural

\footnotetext{
${ }^{160}$ Morrison, Beloved 16.

${ }^{161}$ Morrison, $\underline{\text { Beloved } 6 .}$

${ }^{162}$ Greil Marcus, Invisible Republic: Bob Dylan's Basement Tapes (New York: Henry Holt, 1997) 87$126,107$.
} 
ingredients' with which to construct a reading experience. When we spy the headless bride in the woods, it is a Gothic entertainment more imagined than real. 


\section{CHAPTER THREE:}

\section{RituAl AND SUbJUNCTIVITY IN THE ENGLISH GOTHIC OF THE NINETEEN-SIXTIES}

The black mass is the inversion of the Christian mass thought to be performed by witches and diabolists. Its history does not stretch back nearly as far as the Christian mass. Although it has doubtless been performed on rare occasions since the Middle Ages, the first black mass for which we have substantial documentary evidence was celebrated in Hampstead, on Boxing Day, 1918, by Montague Summers. It is a satisfying coincidence, given what follows in this chapter, that Summers was one of the Gothic's earliest critics. He would author The Gothic Quest, published in 1938, a culmination of a longstanding interest in the genre. We have record of Summer's mass because it was observed by a non-participant, Anatole James, who was 'bored to tears' as Summers performed homosexual acts with a youth named Sullivan while he watched. ${ }^{1}$

Summers claimed to be a Catholic priest, although there is some doubt as to the legitimacy of his ordination. Priestly involvement is a necessity for the black mass, which ought to be officiated by a Catholic clergyman so the host may be transubstantiated before it is blasphemed. In doing so, the mass de-emphasises interpretive meaning in that it is an assault on the body of Christ rather than a mutilation of the symbol of Christ's love and sacrifice. Thus, it is not conceived of primarily as a representational act but an actual work of spiritual violence. While Summers' black mass apparently made for tiresome viewing, textual representations of the black mass typically embrace the pageant and sensuality of the Catholic mass it perverts, involving music, incense and spectacle. It is significant that Summers had an audience for his performance, and that the mass seems to have been a pretext for illicit sexual fulfilment. The representations of the black mass discussed in this chapter are staged performances that act out sexual desire, and are typically observed by a voyeur.

Although seldom represented now, the black mass frequently featured in the English Gothic of the nineteen-sixties. In that context, it was so frequently conflated

\footnotetext{
${ }^{1}$ Gareth J. Medway, The Lure of the Sinister: The Unnatural History of Satanism (New York: New York UP, 2001) 382-3.
} 
with the witches' Sabbat as to be much the same thing. The mass infers Satanists and Satanism, while the Sabbat infers witches who might hold either pagan or Satanic beliefs; I use the terms interchangeably in this chapter. The Sabbat, or at least elements of that black celebration, features in each of the texts discussed in this chapter.

If the Gothic can be understood as a practice, we might describe it as loosely ritualistic. This chapter extends the argument of the first, that the Gothic is a way of reading, by suggesting that reading the Gothic text is an action that incorporates elements of both play and ritual.

Roy Rappaport describes ritual as 'the performance of more or less invariant sequences of formal acts and utterances not entirely encoded by their performers', recreating convention beyond the will of any single individual. ${ }^{2}$ This conception of ritual practice is not far from the way that habitus informs action more generally, although it emphasises a formality that habitus, ever adaptable, is not confined to. Gothics present and re-present similar textual procedures and offer similar reading experiences; they may be more variable than the ritualism Rappaport describes, but their variability is significantly limited; and we may not need to extend Rappaport's description much to include the way that we use Gothic texts to create a particular reading experience.

The texts examined here not only describe the ritual performance of the black mass, but are, in addition, themselves opportunities for ritualised, albeit imaginative, performances undertaken by their readers. Readers and the genre itself return to similar modulations of the same material. Reading is hardly ceremonial, but readers repeat the same act and engage in a similar experience, an experience limited by the possibilities of genre; in this way, reading the Gothic has a ritualistic aspect. The black mass can be read as an emblem or analogue of the Gothic reading experience, becoming a metaphor in which the genre seems to represent its own practice. This chapter argues that ritual is not strongly discursive, and consequently, neither is the ritualised reading experience offered by the Gothic. However, these textual rituals can help us understand how the Gothic's playfully ritualistic texts function.

\footnotetext{
${ }^{2}$ Qtd. in Adam B. Seligman, Robert P. Weller, Michael J. Puett and Bennett Simon, Ritual and Its Consequences: An Essay on the Limits of Sincerity (Oxford: Oxford UP, 2008) 11.
} 
More than a key trope, the black mass was a procedure characteristic of the English Gothic of the sixties; narratives were structured so as to lead towards its performance. Bourdieu notes that artistic fields often enter into 'classical periods', where the art produced presses ever closer to 'perfection', exhausting the potential of a particular approach, and, conversely, 'periods of rupture', where artists produce work that is 'out of joint' with what has preceded it. ${ }^{3}$ While Bourdieu would never have included the productions of popular culture within an 'artistic' field, the observation holds true for the Gothic field. The consistent presence of the black mass in the Gothic of the time suggests that the English field had entered into a classical period, a recognisable era, a category of texts we can consider together. The field itself suggests this category, rather than being an imposed critical notion of a national Gothic of a certain period.

However, we should also recognise that, despite significant likenesses, texts representing the black mass that were present concurrently in the field were not homologous. The ways in which the black mass was used hold likenesses but also significant differences, and considering these likenesses and unlikenesses provides a useful lens with which to focus on the ways individual texts engage with Gothic practice. This approach implies the limits of conventional tropological approaches to the genre and attempts to recognise the Gothic as a historical field, as a historicised practice, and as an experience rather than a discursive space.

Dennis Wheatley was central to the English Gothic of the nineteen-sixties. Now almost forgotten, Wheatley was once a household name and his bestselling books played a central, definitional role in the field. His Gothics, or, in his terms, 'black magic stories', depict the struggles of his fearless heroes against powerful Satanic cabals, and usually narrate the performance of the black mass in one way or another. His version of Gothic practice, here represented by The Devil Rides Out, was so popular and thus influential that it had to be confronted and accepted or refigured by writers attempting their own iterations of the genre. Susan Howatch's derivative romance The Devil on Lammas Night was another bestseller and nicely demonstrates the force of Wheatley's definition of the field.

\footnotetext{
${ }^{3}$ Bourdieu, "Outline of a Sociological Theory of Art Perception" 225.
} 
Neither Wheatley nor Howatch produced work that was understood as literature in the valorised sense. Kingsley Amis provides an interesting point of contrast, in that the writer and his work held considerable, specifically literary prestige. His novel The Green Man is a comic Gothic that features the dark rite in fragmentary form. Without naming it as such, it fulfils a similar function as Wheatley's mass. The black mass is drawn from popular, subliterary or extraliterary Gothic practice, but, somewhat surprisingly, is included with a little modification, inside a text understood to be literary.

Robert Aickman was a well-regarded anthologist and author of 'ghost stories' now virtually unknown even inside Gothic studies. This is a shame as, like Amis, Aickman is a writer of substantial quality, especially when compared to many of the authors working in the field. Unlike Amis' novel, Aickman's stories are unmixed Gothics. The Sabbat-like revels he depicts reconfigure the Wheatleyan Sabbat, and while they make 'sense' in terms of Gothic habitus and narrative, they are not strongly discursive. Nevertheless, Aickman loads the Sabbats central to two of his tales, 'Ringing the Changes' and 'Bind Your Hair', with potential meanings that might be mistakenly understood as requiring the sort of literary practice that demands reflection and interpretation.

Finally, Mervyn Peake's The Gormenghast Trilogy, in many ways an outsider work in the field described here, provides a counterpoint to these representations of the black mass. Peake presents a world stultified by dead ritual, but, curiously, the two potentially efficacious rituals in the texts are both black masses. However, while Peake's performances of the Sabbat are similar in some ways to the others, there are substantial differences, suggestive of how the Trilogy, despite its considerable status within the field today, exists partly outside of the Gothic practice of its first popular readership.

Not all of these texts originated in the sixties, but they are all texts that found their audiences at that time. The recurrence of the black mass reminds us of the repetitive sameness of Gothic practice, but also, that individual differences remain, and that these differences amount to acts of position-taking in the Gothic field. 


\section{The Devil Rides Out}

A brief summation of the year's fiction appears in a December 1961 edition of the Times. It concludes that

No survey of any year's fiction would be complete without paying tribute to that solid middle-rank of literature which, although it commands little reviewing space and no highbrow respect, forms the bulk of the best-seller lists week after week. There have been, for instance, new novels from Mr. Howard Spring, Mr. Frank Swinnerton, Mr. Dennis Wheatley, Miss Georgette Heyer and Mrs. Agatha Christie. They were the work of professionals: they were reliable: they were what the reading public wanted. They were the books that people actually bought, borrowed and read in $1961 .^{4}$

Genre writing is acknowledged and simultaneously dismissed; the separation between literary fiction and genre writing could not be clearer. People actually read genre fictions, but literary productions, not being generally read, remain, by inference, the property of an elite few.

Although far from canonical in a literary sense, by 1969 Wheatley was an institution. He had sold 27 million books worldwide and about 70 percent of those had been within the British market. All of his 55 books were in print. A new Wheatley in hardcover would typically sell 30,000 copies, and paperback sales of his back catalogue stood at more than a million books a year. While Wheatley wrote thrillers in a range of different subgenres, at the end of the sixties it was his 'black magic' stories that were far and away the most popular. While they were moderately successful when first published, they developed their most substantial audience in the sixties. When The Satanist was published in paperback in 1966, it sold more than 100,000 copies in the first ten days. By 1973, five of these eight black magic titles had sold more than a million copies. The first of these was The Devil Rides Out which,

\footnotetext{
4 "Novels of the Year," The Times December 28 1961: 11. The novel referred to is probably Vendetta in Spain, not one of Wheatley's black magic stories; Iwan Hedman and Jan Alexandersson, Four Decades with Dennis Wheatley, DAST Dossier 1 (Köping 1973).
} 
although originally published in 1934, by 1973, helped by the Hammer film of 1967 , had sold more than one and a half million copies, making it the most successful of the group. 5

Wheatley's black magic stories provide a good example of the way that texts persist and accumulate influence in a genre field, gaining non-literary, genre-specific canonicity. They also remind us, given their subsequent disappearance, that any position of prestige is historically constructed and impermanent. Despite his success, Wheatley has received little attention from within the academy, and even within specialised, genre-enthusiastic venues like The Penguin Encyclopaedia of Horror and the Supernatural there is little interest in acknowledging his work in any depth. ${ }^{6}$ Simply, his work has become deeply, embarrassingly unfashionable. Wheatley's imperialist, racist and fascist ideologies are likely to repel casual readers, ${ }^{7}$ while his texts do not provide an especially good venue for academic criticism; all surface, they do not reward careful, deep reading. Nevertheless, Wheatley's influence, which this chapter will outline, coupled with the sheer number of his books sold, indicate that he occupied a central position in the field, and that his approach to the Gothic became a defining one for the practice.

The Devil Rides Out narrates the story of a group of friends locked in a battle with the wicked Satanist Mocata, 'a pot-bellied, bald headed person of about sixty, with large, protuberant, fishy eyes, limp hands, and a most unattractive lisp', based on the notorious occultist Aleister Crowley. ${ }^{8}$ Mocata hopes to start a conflict on the scale of the First World War by performing the appropriate devilish rituals. Led by the aged yet spry Duke de Richleau and garrulous American Rex van Ryn, the friends combat

\footnotetext{
5 "Pooter," The Times 19 August 1969: 19. Hedman and Alexandersson, 20, 73.

${ }^{6}$ Hugh Lamb, "Wheatley, Dennis (1897 - 1977)," The Penguin Encyclopaedia of Horror and the
} Supernatural, ed. Jack Sullivan (New York: Viking, 1986). Wheatley receives a single paragraph, while other, much more obscure writers receive several pages.

${ }^{7}$ In The Devil Rides Out it requires little effort to discern the reactionary and hateful elements of the text; the Satanists form a parade of crude racial stereotypes, Mocata himself is queerly foppish, while the heroes seem to espouse fascism as a tenable political solution.

\footnotetext{
${ }^{8}$ Dennis Wheatley, The Devil Rides Out (1934; London: Mandarin, 1996) 11; Ellis, Raising the Devil 145-6.
} 
Mocata in three substantial set pieces: a black mass in a secluded field in Wiltshire, the defence against Mocata's psychic assault at the stately house, Cardinals Folly, and the pursuit of the occultist to a Satanic temple in northern Greece. They succeed in rescuing their friend, Simon Aron, and the wayward yet beautiful medium Tanith from the Satanist's designs, and also recover Fleur, daughter of their friends Richard and Marie Lou, who had been kidnapped by the diabolist. The text came to define procedures central to the practice; arrangements of narrative and trope, strategies for reading as well as writing that are proprietary to the field.

The first thing to acknowledge about The Devil Rides Out is that it is a ripping story. It is written in language that facilitates the rapid, effortless reading that Nell associates with reading absorption or trance. ${ }^{9}$ Especially in the initial confrontations with the Satanists and the events that lead up to Rex, Simon and the Duke's arrival at Cardinals Folly, the narrative is lurid and fast-paced. In addition to the set pieces, there are a number of effective sequences; the chapter that describes Rex and the Duke's pursuit of Tanith, for instance, is a genuinely well-staged chase scene. Bourdieu claims that 'practice is inseparable from temporality, not only because it is played out in time, but also because it plays strategically with time and especially with tempo. ${ }^{10}$ Wheatley's narrative is urgent, and his books are meant to be read quickly.

Just as Wheatley's tempo is distinct, so too is his tone. The text depicts events so terrible they have the potential to send people mad. The Duke cautions Rex that asylums are full of people who have fallen victim to 'demoniac possession brought about by looking upon things that they were never meant to see', such as the satanic rituals depicted in the text. ${ }^{11}$ However, Wheatley's protagonists do not experience in any real way the crises and collapses that so frequently trouble characters who struggle against the forces of darkness in Gothic narratives. If they experience psychic distress, it is probably caused by evil powers, rather than being a product of their own psyche; this is the case with Tanith's involuntary journey to the Sabbat, or the ordeal of defending Cardinals Folly. Even when de Richlieu's courage fails as he observes

\footnotetext{
${ }^{9}$ Nell 78.

${ }^{10}$ Bourdieu, Logic of Practice 81.

${ }^{11}$ Wheatley 134.
} 
the Wiltshire Sabbat, this failure is temporary; Rex simply treats him as if he has been physically wounded, and the Duke soon rallies. As well as being impermeable, the central characters have an unusual degree of agency; they may be attacked, but none of them are ever victims, as such. The Devil Rides Out is remarkably free of trauma and its sequelæ. The morbid psychological states which often interest the twentieth century Gothic are excluded here in favour of the kind of emotional fortitude found in adventure stories. The effect is remarkable; The Devil Rides Out retains a cheerful tone even as it depicts the appalling. While the narrative facilitates a game of shocks for its readers, testing our 'nerves' and our ability to consume potentially repellent representations, it remains an entertainment. Horror does not haunt or linger in The Devil Rides Out; this encourages ludic reading of the text as the narrative teases out horrors.

The centrepiece of the narrative is the Wiltshire Sabbat. The diabolic mass is threatened at Simon's house in London, and again as Mocata prepares to sacrifice Fleur in Corfu, but is treated most extensively in Wiltshire, where it is represented in instructional detail and drawn out over four chapters. Rex and the Duke cunningly follow the hundred-odd assembled cultists to their gathering point in the depths of the Wiltshire countryside. The narrative focus shifts from Rex and de Richlieu's pursuit and observation, to Tanith's independent arrival, before returning to the two men. This arrangement allows Wheatley to extend his description of the gathering, reiterating the same events from different characters' perspectives. This is unusual in a thriller, which relies on the ongoing release of new information to maintain narrative interest. This repetition of representation delays the climactic action of the scene, where the Duke and Rex rescue Simon by driving their car into the midst of the ritual. Just as significant is the opportunity it provides the reader to 'view' the salacious activity of the Satanists a second time.

Rex and the Duke observe the Sabbat as it unfolds. Rex watches while the Duke describes the process of the ritual prior to its unfolding. "“First, they will make their homage to the devil. Then they will gorge themselves on the food that they have brought and get drunk on the wine; the idea being that everything must be done contrary to the Christian ritual...." 12 Soon afterward, de Richlieu informs Rex that

\footnotetext{
${ }^{12}$ Wheatley 114.
} 
'the baptism... will not be until after they have feasted - just before the orgy., ${ }^{13}$ If the object of the scene were only to shock, then surely surprise would be an aid; the Duke's outline of the ritual's process instead means that the reader cannot be caught off-guard. For Rex, this information is a warning, but for the reader it is a promise that prurient pleasures await.

Wheatley proceeds to describe in remarkable detail the actions that his protagonists witness from their hidden vantage point. If the Gothic reader looks forward to gleeful blasphemy, then this is amply provided, in the sort of sardonic style that The Monk manages so well. A cross is half stomped into matchwood and inverted in the ground, the Christian host is profaned in a way too dreadful to be narrated, and the Duke informs us that the satanic priests are eating 'a stillborn baby or perhaps some unfortunate child that they have stolen and murdered'. Rex is chilled by the sound of a human skull rattling around in their cauldron. ${ }^{14}$ Ostensibly waiting for their chance to liberate Simon, the Duke and Rex are voyeurs, and readers participate in this voyeurism too.

Even Tanith, who, if she were undelayed, would have been a participant, becomes a watcher. She

saw the Satanists strip off their dominoes and shuddered afresh almost retching - as she watched them tumbling upon each other in the disgusting nudity of their ritual dance. Old Madame D'Urfé, huge-buttocked and swollen, prancing by some satanic power with all the vigour of a young girl who had only just reached maturity; the Babu, dark-skinned, fleshy, hideous; the American woman, scraggy, lean-flanked and hag-like with empty, hanging breasts; the Eurasian, waving the severed stump of his arm in the air as he gavotted beside the unwieldy figure of the Irish bard, whose paunch stood out like the grotesque belly of a Chinese god. ${ }^{15}$

\footnotetext{
${ }^{13}$ Wheatley 116.

${ }^{14}$ Wheatley $117-20$.

${ }^{15}$ Wheatley 132.
} 
The reader will remember that Madame D'Urfé is French, and that the cultists are dancing before the Goat of Mendes, who masquerades as Malagasy, earlier described by de Richlieu as 'a "bad black" if ever I saw one'. 16 The human body is textually mutilated, obsessively and grotesquely racialized; Wheatley is simultaneously at his most politically vile and aesthetically Goya-like. The physically grotesque meshes with the crudely sexual and racist. The Irishman is typed as a 'bard' and somehow acquires a second racial classification; the Indian is horrible seemingly because of his race; and Madame D'Urfé is repulsive because her sexuality is framed as inappropriate to her age. The dancing crone is defined in terms of a younger, presumably sexually appealing, woman; even as she is denigrated, the reader is presented with a contrary image. As the sexuality of the Satanists is excoriated, titillation is offered.

In fact, this prejudice is not Wheatley at his worst. Another black magic story, Gateway to Hell, explicitly connects a 'Black Power' movement with a global satanic conspiracy. Wheatley's heroes rescue Nella Nathan, a young Jewish American, from a Sabbat in Chile, where she has been tricked into participating and raped. Nella holds strongly anti-racist beliefs, but barely has time to express them to a disapproving Simon and Richard before she is summarily murdered and mutilated by the cultists she has escaped from. The unspoken logic of the text is that Nella's death is acceptable, even just; she was foolish enough to be dangerous. It is hard to read this as anything other than an especially nasty exercise in authorial projection.

The racism in The Devil Rides Out is complicated, if only a little, by the make up of its company of light, most of whom reappear in Gateway to Hell. De Richlieu is French, Rex American, Marie Lou Russian, Simon a London Jew, and while Tanith's father was English, her mother was Hungarian, and she was raised in Yugoslavia; only Richard is apparently uncomplicatedly English. More than this, the saint who intervenes at the close of the final confrontation with Mocata is seemingly Tibetan (and more importantly, Aryan). ${ }^{17}$ Regardless, a binary opposition is set up between de Richlieu's company, who are cultured and moneyed, and the Satanists, who might

\footnotetext{
${ }^{16}$ Wheatley 11.

${ }^{17}$ Wheatley 315 .
} 
masquerade as civilised, but reveal their savagery at the Sabbat. Their race becomes a symptom of their lack of civilised qualities.

The Duke complains to Rex that 'there is little difference between this modern Satanism and Voodoo... We might almost be witnessing some heathen ceremony in an African jungle!' 18 The Satanists become 'a trampling mass of bestial animal figures' dancing to music where, 'Instead of melody, it was a harsh, discordant jumble of notes and broken chords which beat into the head with a horrible nerve-racking intensity and set the teeth continually on edge. ${ }^{19}$ Music and melody are as much cultural constructions as they are mathematical ones. The breakdown of music suggests a breakdown of culture, more specifically, of Western cultural norms. The Satanists feast, with no 'knives, forks, spoons or glasses', but instead drink straight from bottles and eat using their hands. ${ }^{20}$ This is hardly a transgression on the scale of devouring an infant, but emphasises that Satanism is understood to represent the collapse of civilization, specifically, of a conservative Englishness.

There is a complication in this reading of the Sabbat. Despite its 'savagery', Wheatley has gone to substantial effort to depict occult practice as anything but atavistic. Earlier, de Richlieu tells Rex that if he were to hypnotise a person before an audience of 'ignorant natives' it would seem like magic to them. ${ }^{21}$ Knowledge of the occult is civilised knowledge. Furthermore, if hypnotism is a demonstration of the power of the human will, then the ability to levitate is simply an extension of the same power; this sort of chopped logic is frequently used to 'prove' the Duke's claims. Later, a similarly pseudoscientific rationale is offered for how blood can be used as a source of energy in ritual. ${ }^{22}$ For the Duke, the only reason we might view magic as 'magical' is simply because we are ignorant of its workings. To doubt, as a reader, is to place oneself outside of de Richlieu's worldview; and it is he who carries the authority of the text, his version of the world being borne out by the narrative. The

\footnotetext{
${ }^{18}$ Wheatley 115.

${ }^{19}$ Wheatley 121.

${ }^{20}$ Wheatley 118.

${ }^{21}$ Wheatley 27-8.

${ }^{22}$ Wheatley 117.
} 
Devil Rides Out genuinely tries to construct a certain epistemological credibility, or, at least, the sense of such. Black magic, so often associated with the sorts of superstition supposedly banished by post-Enlightenment thought, is presented as entirely rational. This is a neat inversion, where scepticism becomes unscientific, and magic is no longer a primitive belief. Yet in terms of the Sabbat, described as a site where civilization collapses, this creates an odd tension.

Perhaps the Duke's understanding of the participants' motivations goes some way towards an explanation of why this should be so. De Richlieu believes

'Some of them are probably epileptics, and nearly all must be abnormal. This revolting spectacle represents a release of all their pent-up emotions, and suppressed complexes, engendered by brooding over imagined injustice, lust for power, bitter hatred of rivals... That is the only explanation for this terrible exhibition of human depravity which we are witnessing. ${ }^{23}$

The Duke ascribes ressentiment, the symptom of Nietzsche's 'slave morality', to the Satanists; yet it is the powerful Duke who categorises the Satanists as different, and lesser, placing them in a position where ressentiment seems structurally inevitable rather than an individual failing. Even as the Satanists attempt to use the civilised, scientific knowledge of the occult, they remain excluded. The company of light, all privileged, are free of ressentiment, and thus in the logic of the text deserve their place as masters; furthermore, because they are masters, they are able to wield the powerful and civilised 'science' of the occult in an appropriate way; apparently some are born to rule. Wheatley's racism shades into some kind of fascism.

This sort of reading is useful in that it describes the prejudices and politics of the text. It allows us to see the black mass as meaningful, and helps us place it within a wider discursive tradition. It seems to confirm the approach to genre text that Jameson espouses, suggesting that the text confirms and reinforces a hegemonic worldview for its readers. However, while this sort of reading is politically necessary,

\footnotetext{
${ }^{23}$ Wheatley $120-1$.
} 
it is also very limited in its ability to understand the text's wider interests and practice. While an accusation of xenophobic fascism is demonstrable, it is also too easy.

Regardless of Wheatley's ideology and the racist prejudices of the text, The Devil Rides Out is not a book about race. It is a book about Satanists. Genre habitus allows the native reader to effortlessly grasp this, prioritising certain readings and elements of the text over others. A critical failure to account for the reading strategy presumed by author and audience risks overemphasising what is less significant in a text while missing more important elements. Crucially, a reading that emphasises the political implications of the Sabbat attributes meaning to the ritual; yet the ritual's ability to hold meaning is not what is most important about it. By attributing meaning to the Sabbat, we miss the fact of the Sabbat itself. Rather than a gathering of devil worshippers it has become a demonstration of racist politics.

At the same time, the black mass can go some way towards explaining why Wheatley's black magic stories developed a new readership in the sixties. The black mass becomes legible as a salacious, nightmarish version of some imaginary hippy gathering. While the Satanists are villainous, there is a vaguely progressive air about them; they listen to unconventional music, dance in the nude, participate in unconventional sexual practice, and glut themselves on various intoxicants. This, after all, was the age of Hair, Oh! Calcutta! and $\mathrm{Oz}$ magazine, 'an era of personal liberation, in the view of some critics, one of moral anarchy'. ${ }^{24}$ Without suggesting that the Satanists represent hippies there is a relevancy, a practical sense to their performance that would have been harder to grasp in the thirties.

Seligman, Weller, Puett and Simon note that theorists have tended to emphasise either the social function or the cultural meaning of ritual, but that either of these understandings presumes ritual is basically congruous and coherent with the world, representing things as they are. This has never been the case, they argue. Ritual does not represent either culture or society as they are. Instead, ritual can be seen 'as a subjunctive - the creation of an order as if it were truly the case. ${ }^{25}$ Ritual is a response to a tragic reality that does not align itself with our hopes and wishes,

\footnotetext{
${ }^{24}$ Kenneth O. Morgan, "The Wilson Years: 1964 - 1970," From Blitz to Blair: A New History of Britain since 1939, ed. Nick Tiratsoo (London: Weidenfeld and Nicolson, 1997) 149.

${ }^{25}$ Seligman, Weller, Puett and Simon 20.
} 
rather than a reflection of our world and cultures; the farmer performs a rite to 'ensure' the bounty of the harvest not because the rite represents the order of things, but because sometimes the harvest fails. Interestingly, the Duke's analysis of the Satanists' motivations closely accords with Seligman et al.'s understanding of the need for ritual to console our anxieties and disappointments. The Satanists perform the mass as a response to the disappointment of their lives. Moreover, Seligman et al. argue ritual 'must be understood as inherently nondiscursive - semantic content is far secondary to subjunctive creation.' Ritual 'cannot be analysed as a coherent system of beliefs. ${ }^{26}$

These claims for the nature of ritual have significant implications for any analysis of Wheatley's black mass. If ritual tends to be nondiscursive, then attempts to understand the black mass ought to appreciate this. This does not necessarily mean that discursive meanings, like those discussed above, cannot be attached to it, only that such meaning is secondary to the performance of the ritual itself.

In fact, The Devil Rides Out tends not to focus on the meaning of the black mass, but only on its performance. While the Duke provides a commentary on the action, this commentary only ever extends the description of the action and provides his reaction to it. He is the only figure able to 'explain' the Sabbat, but, unusually, given his verbose theorising of most occult practice, he does not do so. If communion forms the most significant part of the Christian mass, we might presume that the desecration of the host might be the most meaningful part of the rite, but given the extensive description accorded the rite as a whole, it is dealt with surprisingly quickly, receiving only three sentences. The Duke describes the act as 'the most appalling sacrilege', but it is left at that as the celebrants stomp the host into the ground. ${ }^{27}$ The action itself is emphasised over anything it might mean. Far more description is given to the Satanist's nudity, gluttonous feasting and dancing. Again, these are actions that hold sensual qualities for their performers that exceed the simply discursive.

Of course, when we read depictions of these actions, we are not performing them, or even observing them other than in a fictional sense. However, if ritual creates a subjunctive world, we are participating in the sense that the subjunctive world being

\footnotetext{
${ }^{26}$ Seligman, Weller, Puett and Simon 26.

${ }^{27}$ Wheatley 120.
} 
created by the Satanists is much the same as the subjunctive world we are experiencing as readers. On the one hand, we, like Rex and de Richlieu, are simply 'watching' the black mass; on the other, through our reading, we are enacting it on an imaginative level. While de Richlieu and Rex frequently remark on how they are variously appalled and repelled by what they are seeing, this is an unlikely reaction for the reader. Witnessing the performance of the black mass is perhaps the primary satisfaction of the black magic story; readers who did not wish to be thrilled and titillated by it are unlikely to have engaged with the text in the first place.

Before Wheatley's readers attempt to assemble a sense of what the ritual might mean, they experience the subjunctive world of the ritual itself. The Sabbat offers a tawdry, intoxicated vision, full of weird violet lights and blue candle flames. The Satanists burn incense made from 'Thorn, apple leaves, rue, henbane, dried nightshade, myrtle and other herbs... Some are harmless apart from the stench, but others drug the brain and excite the senses to an animal fury of lust and eroticism' explains the Duke. ${ }^{28}$ It is intoxicating, a darkened carnival apart from the real. The subjunctive space created offers readers the imaginative experience of a morbid but heavily eroticised world, where Gothic practices are acted out. In this way, the subjunctive created by the black mass is approximately equivalent to the subjunctive Wheatley's text proposes to his readers, and presents those elements of the text which are characteristic of Wheatley's Gothic practice.

Chapter one raised concerns about the usefulness of trope as a key to understanding the Gothic genre. The Sabbat is a trope, but more than that, it is a procedure, played out in the narrative, and in the act of reading. The Sabbat works towards a climax; however, that climax is interrupted by the intervention of the Duke and Rex, who drive the Duke's car into the centre of the rite, switching its headlights on as they descend into the valley:

At the first flash of those blinding lights which struck full upon them, the Satanists rushed screaming for cover... Their maniacal exaltation died away. The false exhilaration of the alcohol, the pungent herbal incense and the drug-laden ointments which they

\footnotetext{
${ }^{28}$ Wheatley 116.
} 
had smeared upon their bodies, drained from them. They woke as if from an intoxicated nightmare to the realisation of their nakedness and helplessness. ${ }^{29}$

Spiritual darkness is dispelled by the light of the Duke's headlights, which break the spell of the subjunctive the ritual works towards. Spiritual and actual darkness are conflated, so that evil can be apprehended through the senses. A notional darkness becomes actual for a short time. This literalization confirms the subjunctive nature of the Sabbat, creating a world where it is as if darkness reigns, a spell that is broken by the light.

As we will see, the Sabbat is usually interrupted before it reaches a climax. This interruption creates a mesh of effects. It frustrates the reader's interest before the whole of the ritual has been played out, and thus maintains that interest. This is the experiential equivalent of the way that narrative holds back information, deferring the readerly pleasure of revelation until a later point. At the same time as teasing the reader's prurient interest, interruption affirms the power of the black mass itself by hiding its culmination, suggesting that there is something more, unseen, obscene, and blasphemous that the ritual is proceeding towards, but that remains unperformed. While the potential power of the black mass is celebrated, it is also safely occluded.

While the mass is being celebrated, the Satanists become an undifferentiated mass, their everyday identities and individuality subsumed into the subjunctive world created by the ritual. Simon, a willing participant, becomes lost amongst them, his individual identity subsumed into the subjunctive being created by the group. Rex and the Duke are outside of this subjunctive world, expressing revulsion, but voyeuristically looking on; they retain their individual identities. Tanith is caught between the role played by Simon, and the one played by the Duke and Rex, as she risks shifting from observer to participant, becoming swept up in the performance of the rite, her journey to the Sabbat being driven on by 'evil powers'. ${ }^{30}$

These three relationships to the Sabbat suggest some of the strategies available to its readers. Like Rex and the Duke, we seem to observe the black mass as voyeurs,

\footnotetext{
${ }^{29}$ Wheatley 135-6.

${ }^{30}$ Wheatley 131.
} 
and still have the option of disapproving of it, but like Simon, the act of continuing to read means that we are participating in this perversity, at least fictionally. Having committed to reading a black magic story, the reader's procession towards the black mass is inevitable, as with Tanith's procession towards it. Yet, just as Tanith is compelled towards it, readers are allowed to experience the Sabbat without having to see themselves as wanting to experience it. This facilitates a ludic, nondiscursive reading experience; readers are not encouraged to seriously reflect on what the Sabbat means or why it might be a source of vicarious pleasure. They do not have to take responsibility for it. As much as the Satanists create a subjunctive world for their own ends, readers are creating a similar world for themselves to participate in. The Devil Rides Out depicts distinct kinds of ritual, but also is an opportunity for a distinct kind of ritualised reading.

Seligman et al. construct a binary distinction between the ritualistic and the sincere. Sincerity, in their usage, marks an approach to the world that emphasises the individual subject, authenticity, and the need to get at 'real' thought and feeling, existing in contradistinction to ritual, which emphasises the communal, the conventional, and the performative. They argue that 'The sincere mode of behavior seeks to replace the "mere convention" of ritual with a genuine and thoughtful state of internal conviction. ${ }^{31}$ This theorisation of ritual is close to Bourdieu's, which argues that 'one cannot speak adequately of ritual unless one understands that ritual is essentially behaviour that is both 'sensible' and devoid of sense intention and that scientific intention is essentially the project of discovering sense'. ${ }^{32}$

Where the sincere is meaningful, the ritualistic is significant. In The Devil Rides Out, the black mass, a largely unreal practice, must be regarded as insincere. More important than any 'meaning' we might extract from the rite is the simple fact of participation. The individuality and agency of the participants is apparently diminished in the mass, and their regular sense of themselves is recovered only as the car's lights dispel the subjunctive darkness. Likewise, the Gothic reader's self and discursive ability is not emphasised in this immersive reading experience; we keep reading without pausing to really consider the mass itself. Indeed, when we read the

\footnotetext{
${ }^{31}$ Seligman, Weller, Puett and Simon 103.

${ }^{32}$ Bourdieu, Logic of Practice 18.
} 
black mass, we tend to put our day-to-day values, both moral and aesthetic, to one side, bracketing our sincere individuality in favour of participation in the text. Reading the black mass is emblematic of reading the Gothic itself, where the reading experience itself exceeds the meanings carried in the text.

Part of what makes Wheatley's black mass so useful to the Gothic is that it is largely invented. The rituals performed by occultists like Crowley were not understood by their participants as being black masses, and it was not until the foundation of the Church of Satan in San Francisco in the later nineteen-sixties that it seems the black mass was performed with the regularity or uniformity characteristic of ritual. Instead, its celebration was limited to eccentrics and dabblers like Summers. The black mass, as it is presented in The Devil Rides Out, is an invention, although an invention with considerable precedent in Gothic lore and literature. ${ }^{33}$ As an imaginary ritual, the black mass can be whatever the Gothic text requires it to be. Thus the Sabbat provides an opportunity to stage those actions and experiences required by the contemporary Gothic.

\section{The Devil on Lammas Night}

If The Devil Rides Out is a good bad book, then Susan Howatch's 1973 The Devil on Lammas Night is, comparatively, uncomplicatedly poor. Nevertheless, it was still in print some seven years after its original publication, in part due to Howatch's success with a number of thick historical blockbusters written shortly afterward. ${ }^{34}$ The Devil on Lammas Night goes some way towards demonstrating the force that Wheatley's first and subsequent black magic stories exerted over the field at the beginning of the seventies. There is reason to think that Howatch drew directly from Wheatley; but more interesting are the substitutions and rearrangements she makes, and their apparent modest success, suggesting that it was a competent and timely performance of the Gothic.

\footnotetext{
${ }^{33}$ For an account of historic depictions of the black mass, see Medway.

${ }^{34}$ Philippa Toomey, "Sex, Lust Greed," The Times 1 November 1980: Saturday Review 10.
} 
The Devil on Lammas Night is The Devil Rides Out for readers who prefer their Gothics in the mode of Victoria Holt's comparatively demure, romantic 1960 governess-Gothic, Mistress of Mellyn. As with the Wheatley, the black mass is central to Howatch's narrative. The plot involves the efforts of a group of Satanists, led by the charismatic Tristan Poole, to inveigle their way into Colwyn Court, ancestral seat of the financially troubled Walter Colwyn. The Satanists masquerade as the seemingly innocent Society for the Propagation of Nature Foods, but use the occult means at their disposal to bring about a number of deaths amongst the Colwyn family and their friends, nearly scuppering the budding romance between Walter's son, the young doctor Evan, and Nicola Morrison. Where Mocata is attempting to bring about a conflict similar to the Great War, Poole represents a threat to domestic romance rather than world peace.

The Satanists pursue the Morrison family fortune, killing Nicola's father (he swerves his car to avoid hitting a cat that Tristan has bewitched), and her stepmother (she is swept off a cliff by a flock of stampeding sheep, driven towards her by a demonically possessed horse). The absurdity is unintentional, but makes The Devil Rides Out seem comparatively serious.

Howatch's central plot-proposition, where an otherwise eligible young woman becomes involved in a satanic cult and must be removed from such by her suitor, had already been used by Wheatley. Evan and Nicola's romance owes much to Rex and Tanith's; the bridegroom may not claim his bride until she has been recovered from the Satanists. However, the scale of the action in The Devil on Lammas Night is considerably reduced, despite the eventual revelation that Poole is an incarnation of the devil himself. This reduction in scale distinguishes the differing orientations of Wheatley and Howatch's texts. Wheatley's text participates in the thriller genre at the same time as the Gothic, whereas Howatch's participates in the paperback romance, an earnest descendent of comedy. Frye's conceptualisation of comedy usefully describes the issues Howatch's narrative works through. Comic narrative resolves when the young lovers are wed, and in doing so, bring about change in the social order. Frequently, comedy also expels a scapegoat figure from that society; while its theme is integration, it also indicates what it is not possible to integrate. ${ }^{35}$

\footnotetext{
${ }^{35}$ Frye $163-86$.
} 
It is established that Nicola must partner Evan, who has recently returned from Africa, and that Evan ought to take control of the Colwyn estate from his weakening father. Poole is an interloper, and his diabolic power is such that he has manipulated Colwyn père into accommodating the Society for only a peppercorn rental! Tristan has a hypnotic power over almost all of the women he encounters. He is marked as desirable, yet foppish and foreign:

the impression of the conventional English businessman, so meticulously created, was blurred by his hands and voice. He had beautiful hands, the fingers long and tapered, and contrary to the habits of many conventional Englishmen he wore a ring on the third finger of his right hand, an intricate un-English ring... When he spoke... it was hard to decide why [his voice] should fall short of conventional English standards, but after a time... a listener could detect the inflections of a foreigner in the occasional ambiguous vowel sound or choice of words... he was closer to forty, cosmopolitan, experienced and immeasurably sophisticated. ${ }^{36}$

Poole is not as grotesque as Mocata, but carries the same set of prejudices about foreigners and cosmopolitan men as Wheatley's villain. Mocata is French, and popular with women; however, he does not conform to an English notion of gentlemanliness, with Simon informing us that 'He does the most lovely needlework, petit point... he will smother himself in expensive perfumes and is as greedy as a schoolboy about sweets'; but he also disappears into the East End for days on alcoholic benders where he indulges terrible, nameless vices. ${ }^{37}$ The Devil on Lammas Night, as much a paperback romance as a black magic story, is careful not to attribute too much foppish bizarrerie to a potential sexual partner of the heroines. Tristan's allure needs to be available to the reader as much as to Nicola, Gwyneth (Walter's unworldly daughter) and Lisa (Nicola's stepmother).

\footnotetext{
${ }^{36}$ Susan Howatch, The Devil on Lammas Night (1970; London: Pan, 1974) 24-5.

${ }^{37}$ Wheatley 153-4.
} 
The threat posed by the diabolists is appropriate to the stakes of each narrative. Thrillers require that potentially explosive political situations be negotiated; paperback romances operate on a smaller scale, and are interested in the complications of personal relationships. In terms of the other genres the texts participate in, the threat posed by the devil and his agents is similar, in that the fundamental narrative requirements of those genres are threatened by diabolic agency. In the case of both texts, this simultaneous involvement in different genre practices is carefully orchestrated, so that the potentially competing requirements of variant genre procedures do not appear as wildly inconsistent, although admittedly Wheatley is probably the more successful of the two in this.

In The Devil Rides Out, the black mass is more than simply a mass, having been conflated with other ritual functions. It is intended to provide an initiatory 'ordeal' for Tanith, and to infernally baptise Simon. ${ }^{38}$ The Devil on Lammas Night's black mass is similar in that it is also intended as Nicola and Tristan's wedding ceremony. Howatch reorientates the mass so that it includes the ultimate threat possible in a paperback romance narrative, coupling with the wrong partner, a threat that is averted when the mass is interrupted.

Howatch's presentation of the black mass has much in common with Wheatley's. As with Mocata's ritual, there is feasting, and participants burn herbs that emit noxious, intoxicating fumes. The list of ingredients that feature in the incense strongly suggests that Howatch drew directly on The Devil Rides Out as a source. Agnes, Poole's lieutenant, describes the ingredients as 'Rue, myrtle, dried nightshade, henbane and thorn-apple. ${ }^{39}$ This is almost identical to Wheatley's list, although thorn and apple have been compounded into thorn-apple, or datura. Where Wheatley has his Goat of Mendes trample a cross into matchwood, Howatch limits herself to having a tapestry of the same scene hanging behind the altar. ${ }^{40}$

Two members of Howatch's company of light observe the gathering prior to the Sabbat, and the Sabbat itself, from hidden vantage points. The Devil on Lammas Night is voyeuristic, but less so than Wheatley. As Jane Shaw spies on the Sabbat, we

\footnotetext{
${ }^{38}$ Wheatley $85,91$.

${ }^{39}$ Howatch 187.

${ }^{40}$ Howatch 202.
} 
learn that while 'she was not prudish', she 'thought that human beings usually looked better with clothes than without them... [although] she found herself riveted to the spot with an appalled fascination.' She wonders how the 'elderly, the obese and the ugly could reveal themselves in such a way without a qualm'. ${ }^{41}$ Again, the reader is placed in a voyeuristic position alongside Jane, but where the Duke's appalled cries only emphasise the provocative, forbidden nature of the worship, Jane's response represents a flatter rejection of what she sees.

Jane embodies common sense; she is a stark contrast to her muddled and ineffectual husband, Cambridge professor Bernard. Unlike dreamy Nicola and Gwyneth, and vain Lisa, she is not susceptible to Tristan's charms. While she spies on the Sabbat, she resists the lure of its subjunctive world. The objection to the coven's nudity again rests on the unappealingness of their bodies, although their grotesquery is not on the scale of Wheatley's deformations, nor is it racialized. More importantly, Jane's objection does not involve the shock and moral outrage of the Duke's response. In the black mass, ritual nudity ought to be erotic and shocking rather than pathetic. Where Rex and the Duke participate in the Sabbat through their outraged spectatorship, and are thus accessories to the Sabbat's subjunctive world, Jane resists, refusing to participate by not accepting the terms of the game. Rather than being a celebration of transgression, this part of the Sabbat is merely embarrassing. Jane's resistance to the Sabbat's creation of a subjunctive world implies a reader likely to resist this world too. The Devil on Lammas Night's simultaneous practice of the paperback romance genre limits the Gothic's transgressive tendencies; the book promises horrors and salaciousness, but carefully limits its shocks.

It is the black mass' facilitation of orgiastic sex that Jane finds most unsettling. She does not weep when Matthew, Nicola's father, or Lisa, her stepmother, die; but she is reduced to tears thinking of Nicola participating in unconventional sexual practices. ${ }^{42}$ As in Wheatley, the participants in the mass are treated as an undifferentiated mass, anathema to the pairings and carefully delineated social roles comic narratives require. The orgy is particularly threatening as it disregards the principles of comic narrative.

\footnotetext{
${ }^{41}$ Howatch 204.

${ }^{42}$ Howatch 190.
} 
No access is provided to the consciousness of Nicola, the heroine at risk of becoming lost in the polyamorous mass. This is unlike the case of Wheatley's Tanith, who almost leads us into the Sabbat. Just as Jane rejects the erotic frisson of ritual nudity, so too the reader is directed away from the risk of becoming swept up in the mass. Indeed, the mass itself occupies only a few pages before it is interrupted. The ability of the ritual to create a subjunctive world is limited in comparison to Wheatley's Sabbat.

In The Devil Rides Out, it is the Duke's wealth of occult knowledge that allows the company of light to battle the Satanists. When de Richlieu and Rex disrupt the ceremony, they visualise occult symbols, throw a cross at the Goat of Mendes, mutter psalms and use physical light as a weapon against spiritual darkness; all of this comes from the Duke's instruction. The Devil on Lammas Night's black mass is also interrupted through the savvy use of occult practice. Jane has already sent Evan to Foyles to purchase 'a really good book on witchcraft', ${ }^{43}$ which has confirmed her suspicions that witches are at work. Her frantic recitation of the Lord's Prayer helps to interrupt the mass, rupturing the delicate subjunctive atmosphere the witches are attempting to create. Evan's cry, 'In the name of God, STOP! ${ }^{44}$ also contributes to the cessation of the ceremony, but it is Timothy's action that kills Poole. Plucky young Timothy, shut up in Colwyn Court by the Satanist, discovers the wax doll that Poole has previously used to incapacitate Evan. Timothy inspects the doll:

Stories began to flicker across his memory, folklore handed down from one generation of schoolboys to another... This was how you won a fight with the school bully even though he was much bigger than you were. You stole a candle from the school pantry, melted it, moulded it into the bully's image, pricked it in the groin with a pin, muttered 'I hate you' three times... The bully would lose all his strength and lose the fight. Timothy had

\footnotetext{
${ }^{43}$ Howatch 167-8.

${ }^{44}$ Howatch 208.
} 
never tried the experiment himself but everyone at school was positive that it worked. ${ }^{45}$

Timothy removes the splinter from the Evan doll, makes an image of Tristan, prays to God, and skewers its heart, causing Tristan's sudden death. Timothy's action aligns him with Jane's common sense. Wheatley's heroes contribute to the creation of a Gothic world through their horrified reactions, while Howatch's, always sensible, resist the subjunctive of the black mass.

There is a significant difference between the way that knowledge functions in the Howatch and the Wheatley. De Richlieu flies to the British Library to research the techniques of his enemies, and the knowledge that allows him to battle Mocata is hieratic, occult, and elite. The knowledge that allows Jane and Timothy to defeat Poole's coven is available in good bookshops and passed around at public schools. This is a significant modification of Wheatley's technique. Mocata needs to be combated by specialists, whereas non-specialists armed with folklore and the procedures of practical logic can stop Poole. Timothy's hex on Poole is a demonstration of the sort of knowledge that emerges out of Gothic habitus, and is, in this way, an action informed by common sense, or, at least, the Gothic version of common sense.

Bourdieu argues that an emphasis on language and hermeneutics 'leads one to conceive action as something to be deciphered, when it leads one to say, for example, that a gesture or ritual act expresses something, rather than saying, quite simply, that it is 'sensible' (sensé) or, as in English, that it 'makes' sense. ${ }^{, 46}$ By the seventies, the black mass, a textual manifestation of Gothic habitus, had developed to the point where it could be described as 'sensible', as could the actions typically taken to circumvent it.

The subjunctive world of the black mass, and by extension, the Gothic offered by The Devil on Lammas Night, relates to the real in a slightly different way to Wheatley's text. In the late sixties, Wheatley's Satanists could potentially be read as countercultural freaks. Howatch's coven members, however, are unambiguously

\footnotetext{
${ }^{45}$ Howatch 201-2.

${ }^{46}$ Bourdieu, Logic of Practice 36-7.
} 
linked to free-loving liberals and hippies. Tristan is a re-reading of Mocata, but an entirely contemporary one, drawing on then-current anxieties relating to cults and their leaders. The Scientology cult had been investigated by the British government and was decried in the papers in the sixties; one of the key objections raised was the cult's claims to provide mental health care, when it was completely unqualified to do so. A report in The Times noted that 'Its practitioners, medically unqualified, practised "dangerous (hypnotic) techniques" and not only administered the wrong treatment but also poisoned people's minds against orthodox medicine', and that Scientology's founder, L. Ron Hubbard, falsely claimed to be a doctor. ${ }^{47}$ Tristan claims to be a psychologist, but is not, in fact, a qualified doctor, much to Evan's outrage. Indeed, Tristan uses hypnosis to control people and bring about his ends. ${ }^{48}$ Although Tristan never claimed to be a psychiatrist, that the distinction is highlighted suggests Tristan is being likened to Hubbard.

Another point of reference appears in English reporting of the Manson family murders. Manson's control over female cult members and his polygamy were emphasised, as were his links to the Haight-Ashbury hippy scene, and allegations that he was involved with black magic. ${ }^{49}$ Tristan's accent is un-English because he spent time in California, and it was there that he changed from man into Beast. His promiscuity exceeds that of the typical romantic cad, in that he has a coven of no less than twelve women under his control. The zeitgeist of the sixties opened up another way of reading The Devil Rides Out as a nightmare representation of hippie culture. Howatch's book embraces this alternate reading.

However, The Devil on Lammas Night is not substantially an expression of contemporary cultural anxieties about cults and young people. These ideas are used not because the text wishes to seriously investigate them, but because they provide a sense of plausibility for the plot. Despite the improbabilities of the narrative (a possessed cat, a death caused by stampeding sheep), Howatch refers to the real, but only as a source of credibility. More important than reference to contemporary cult leaders is Howatch's extensive borrowing from Wheatley. That Wheatley's text

\footnotetext{
${ }^{47}$ Henry Stanhope, "How Cult Deals with Its Critics," The Times 26 July 1968: 8.

${ }^{48}$ Howatch 152.

${ }^{49}$ See Michael Knipe, "Cult Leader Sent His Girl Friends out to Beg," The Times 6 December 1969: 4.
} 
should provide so much for Howatch's suggests the powerful position that Wheatley held. Wheatley's version of the black mass had become a resource available to others participating in the field.

\section{The Green Man}

Kingsley Amis' 1969 novel The Green Man has a Gothic appeal very different from Wheatley's. It is, on the one hand, a ghost story, and on the other, a typically Amisian comic novel, and as such, occupied a position of prestige in the literary, as opposed to the Gothic field. In fact, it was marketed separately to both fields; originally in hardback by Jonathan Cape, it was released as a paperback in the Panther Horror imprint in 1971. While The Green Man does not feature the black mass, it features elements that seem to be drawn directly from it. Neither the ghost story nor the comic novel requires the appearance of a wicked occultist or phantasmagoric sexuality, but these details are central to Amis' narrative. That it should include these elements is, again, indicative of the power of Wheatley's definitional position in the Gothic field. The Green Man suggests that the literary text depends on contemporary Gothic practice to inform its performance when it takes a ghostly turn.

The novel participates in both the Gothic and literary fields. Its Times reviewer noted that 'I quite enjoyed it at first, became slowly unscared, was thoroughly disappointed by the end, and only began to relish it an hour or so after I had put it down. ${ }^{50}$ This response suggests a process that, over the course of the reading experience, responds in turn to the different genres the text is involved in. The reviewer moves from pleasurable Gothic affect, and enters into a period where he is dissatisfied by the text; he notes his initial enjoyment fading as he becomes 'unscared'. The novel has failed to do what a Gothic ought. Then, on reflection, the reviewer seems to find another way of appreciating The Green Man. It is this act of reflection, which occurs separately from the act of reading the text that marks the reattribution of genres. His reading has become a reflective, literary consideration of the book rather than an immediately affective Gothic experience. It seems a fair

\footnotetext{
${ }^{50}$ Michael Ratcliffe, "Two's Company, but One's a Crowd," rev. of The Green Man, by Kingsley Amis, The Times 11 October 1969: Books v.
} 
assessment of a text that vacillates between boozy, uptight comedy, sharply edged satire, and ghostly irruptions.

Maurice Allington, a chronic alcoholic and serial womaniser, owns an inn in Hertfordshire, the Green Man, which is said to be haunted by the ghost of Dr Thomas Underhill, a man of holy orders and wicked repute from the later seventeenth century. Over the course of a catastrophic few days, Maurice's father dies, he seduces his doctor's wife, Diana, and then coaxes her into both helping him exhume the body of Underhill, and also into bed with himself and his wife Joyce. He experiences hallucinations, psychic attacks, odd episodes where time freezes, the appearance of Christ, amnesiac spells and eventually the manifestation of the green man itself, a monster formed of forest stuff and animated by Underhill's magic. It is a polygenous text, and provides more than a simple Gothic.

While Amis is best known as a literary writer of comic novels, The Green Man is an informed contribution to genre writing. Amis was one of the first academics to specifically address genre fictions in his work of popular criticism, the short 1960 survey of science fiction, New Maps of Hell. While New Maps of Hell is primarily interested in science fiction, that genre is, in Amis' descriptions, closely interwoven with what he terms 'fantasy', something close to what would now be labelled Gothic. Amis believes Ray Bradbury is a key proponent of this 'fantasy' writing, and notes the macabre turn which fantasy seemed to have taken. Amis feels that cruelty and disgust

run riot in a good deal of modern fantasy, more often in what is not an overtly sexual form... Stories about evisceration, or mutilation in general, once fairly common in science fiction of the madscientist school, are now a settled ingredient of fantasy. ${ }^{51}$

The Green Man is overtly sexual, but does not dwell on gore. Nevertheless, the blending of the sinister with the sexual suggests Amis was consciously participating in 'fantasy', or the Gothic field. Just as The Times' reviewer noted the distinct pleasures of the Gothic and literature available in the text, New Maps of Hell

\footnotetext{
${ }^{51}$ Kingsley Amis, New Maps of Hell (1960; London: New English Library, 1969) 57.
} 
recognises these too. Amis argues that there is a real difference between the pleasure sought by the genre fan reader as opposed to the literary reader, ${ }^{52}$ which is another way of acknowledging the differing expectations and reading strategies readers use.

The Green Man opens with a review of the eponymous establishment from the Good Food Guide, that praises its 'genuine English fare', and introduces Maurice as the proprietor, who is prepared to tell his guests the story of the inn's haunting; we learn 'there is, or was, at least one ghost' ${ }^{53}$ This is a very different presentation of a supernatural, Gothic manifestation to that presented in Wheatley. The ghost is treated as a story, rather than as a real thing. It is a tourist attraction rather than a threat. This introductory framing of an apparition as fictive, only to have it proven 'real' later, is not uncommon in Gothic narrative. Like the black mass, it is one of the ways in which Gothic fictions incidentally examine themselves, shifting from a representation we recognise as banal, real, in which ghosts are only a story, to an extraordinary space where they become real within the story. These Gothic narratives suggest the reader's shift into the subjunctive.

The review acknowledges that the ghost is a source of interest for readers, an entertainment, almost a part of the inn's hospitality. Rather than immediately involving the reader in the creation of a Gothic reading experience, The Green Man opens with a description of the reader's relationship to Gothic narratives. Shortly after Maurice has described the travails of innkeeping, he goes into 'the routine', recounting the purported ghostly history of his house to a pair of American guests. Maurice reflects 'I usually enjoyed telling all this, but tonight it seemed silly, fully vouched for by written evidence and yet at the same time a blatant piece of stock-intrade. ${ }^{54}$ Maurice's sensibility tends to realism on this occasion, seeing his Gothic narrative as daft, theatrical, a charade.

Yet the narrative soon becomes more certainly Gothic, culminating in events that mirror the black mass, without actually being that rite. Underhill's ghost becomes more active, and Maurice, seemingly in his thrall, digs up his grave and removes a

\footnotetext{
${ }^{52}$ Amis, New Maps of Hell 12.

${ }^{53}$ Kingsley Amis, The Green Man, (London: Jonathan Cape, 1969) 9.

${ }^{54}$ Amis, Green Man 17.
} 
silver talisman the dead sorcerer requires. The two meet in the dead of night, and by way of thanks Underhill presents Maurice with a pornographic phantasmagoria:

A group of naked women flashed into apparent existence, in midperformance of some sort of slow, writhing, vaguely Oriental ballet. Their voluptuousness was extreme, and also theoretical, like the fantasy-drawings of a prurient but talented schoolboy... 55

Maurice voyeuristically watches an orgy unfold before him, accompanied by strange music and overpowering scents, although he is uncomfortable that a pair of glowing red eyes seems to float behind the action.

Underhill's show draws on elements of Wheatley's Sabbat beyond the simply orgiastic. The phantasmagoria seems to call forth the monstrous green man, with the chants that raise the monster blending with the pornographic illusions. Maurice becomes entirely deluded, believing he is being assailed by small birds, but is able to dispel the illusion by throwing his crucifix at Underhill ${ }^{56}$ - just as Rex attacks the Goat of Mendes by throwing a crucifix at it. Once it has appeared, the green man attempts to snatch Maurice's daughter Amy on Underhill's behalf, just as Mocata snatched Fleur for his ceremony in Corfu and Poole ensorcelled young Lucy so that she could assist in the performance of the Sabbat. Unlike the black masses in Wheatley and Howatch, the pseudo-mass in Amis is not interrupted, and the dreadful force the mass builds towards is released into the narrative.

Despite the similarities, Underhill's phantasmagoria is distinct from the black mass. Where one is a ritual, Underhill's illusions are intended as an entertainment. However, Richard Schechner argues that 'Western thinkers have too often split ritual from entertainment, privileging ritual over entertainment' and instead believes "entertainment and ritual are braided together, neither one being the "original" of the other. ${ }^{57}$ This is relevant here in two ways. Firstly, it suggests that there is a basic

\footnotetext{
${ }^{55}$ Amis, Green Man 221.

${ }^{56}$ Amis, Green Man 224.

${ }^{57}$ Richard Schechner, Performance Theory, revised and expanded ed. (New York: Routledge, 1988) 155.
} 
homology between the black mass and Underhill's illusions. Secondly, if we see Maurice and the other Sabbat voyeurs as representative of the Gothic reader, we are reminded that there is a ritual element in our spectatorship of these entertainments.

The Duke and Rex are like successful Gothic readers, looking on as the Gothic is performed, unreflectively reacting to the horrors (or are they delights?) presented; they are caught up in the Gothic moment. Both Maurice and Jane fail to become caught in the subjunctive worlds created in the performances they witness, suggesting the delicate boundaries of the Gothic performance. Maurice and Jane's involvement is limited by their sincerity, in Seligman's sense of the word, their reference to their own subjectivity rather than to the subjunctive's tendency to involve and overwhelm its participants and viewers.

Maurice's resistance to the supposedly pleasurable representations before him is strongly coloured by his real experience. He has recently persuaded Joyce and Diana to join with him in a threesome, but becomes marginalised during the sexual encounter, as the two women discover a passion for one another that excludes Maurice. When Underhill presents Maurice with a vision of two blonde women in lesbian embrace, which Maurice takes to refer to his wife and his lover, he describes it as 'an outstandingly abortive attempt to entertain me. ${ }^{58}$ The earlier visions presented to him are simply not to his taste, but Maurice's final objection comes when something that recognisably relates to his own history is presented. He views Underhill's visions as escapist, not as properly relating to his life. Where Maurice is able to provide a Gothic entertainment for his American guests with a ghost story, it remains diverting rather than relevant to them; Underhill's cave of dark pleasures fails to hold Maurice's interest in part because it is poorly crafted, but also because it touches on the real, recalling Maurice's life, thus spoiling its escapist potential.

The text itself shifts between escapist fancy and engaged discourse. Typical of this style is Maurice's audience with 'the young man', a figure that seems to represent Christ, who provides him with advice as to how he might defeat Underhill. Christ is little concerned with notions of good and evil, and declares that unjust suffering is

\footnotetext{
${ }^{58}$ Amis, Green Man 222.
} 
'simply the run of the play. ${ }^{, 59}$ He desires Underhill's defeat not because the sorcerer is wicked but because it suits his aims in some cosmic game he is playing.

In this view of the cosmos, the Church can hardly claim a morally privileged position. Nevertheless, Christ endorses the power of the local vicar, the Reverend Tom Sonnenschein. Sonnenschein is a figure of fun, queer, modish, a Marxist who rejects Church doctrine. He claims that the immortality of the soul and hell are both Victorian inventions, and drinks Bacardi and Pernod with ice, ${ }^{60}$ presumably a bizarre variation on a Sazerac; Amis uses drinks throughout to denote character. Christ advises Maurice:

Use the Church where appropriate. Oh, I don't mean go and listen to that posturing idiot Sonnenschein making me out to be a sort of suburban Mao Tse-tung. But remember that he's a priest of the Church, and as such he has certain techniques at his disposal. ${ }^{61}$

Maurice tricks Sonnenschein into exorcising the inn and the nearby woods, even though the priest does not believe that the ritual of exorcism holds authority.

We tend to think of this kind of ritual as requiring sincerity, a 'genuine and thoughtful state of internal conviction' to be efficacious, ${ }^{62}$ but this is not necessary in the world of The Green Man. The text accepts Seligman's thesis, that ritual simply requires performance more than sincere belief in its precepts. Again, this is a useful point when we consider the Gothic text. We commit to the performance of the text through our reading act, even if we most likely disbelieve that diabolists can call up ancient spirits and animate forest matter, or find the power of the Church to enact spiritual good questionable. This is not so much a question of 'suspending our disbelief' as becoming involved in another sort of game, which entirely distracts us from it.

\footnotetext{
${ }^{59}$ Amis, Green Man 203.

${ }^{60}$ Amis, Green Man 178-82.

${ }^{61}$ Amis, Green Man 206-7.

${ }^{62}$ Seligman, Weller, Puett and Simon 103.
} 
Sonnenschein himself emphasises his interpretive ability and his engagement in political discourse. This is exactly what Christ dismisses. Sonnenschein's ability to produce meaning is irrelevant, but he still has a role in the game that is being played. Beyond the subjunctive world of crude pleasures Underhill creates, The Green Man creates a wider world where spiritual forces are in conflict, but there is no substantial moral meaning in this. Evil must be stopped, but not because it is wrong, per se. The text's principle is performative and ritualistic rather than sincere.

The absence of sincere weight in the moral framework in which the action of The Green Man is played out is emphasised when we see that although Maurice is basically comic, a cuckold, he is doubled with Underhill. Underhill appears only to Maurice, and both are lustful old men. It is Maurice's research into Underhill's research that facilitates his return. This is a reversal of the pattern in Wheatley and Howatch, where research into the occult allows the heroes to better resist the powers of the Sabbat. In The Green Man the villain is an uncontrolled version of its hero. Sexual rapacity was a significant motive for Underhill's occult researches in his lifetime. Maurice's daughter Amy's entry into her teens, presumably suggesting her nascent sexuality, is cited as the reason for Underhill's return in the late nineteensixties. ${ }^{63}$ Likewise, Maurice is almost as obsessed with sex as he is with alcohol. 'It has never surprised me that some men should not try to beat Don Juan's traditional total, only that more do not', ${ }^{64}$ he reflects. Comedy is often concerned with demonstrating the exclusion of certain elements from society, typically in the figure of a scapegoat. ${ }^{65}$ Underhill is hardly a scapegoat, but his rapacity is excluded through his final exorcism. Maurice, his double, is expelled at the conclusion too - Joyce and Diana choose to partner one another, and Maurice must seek a new inn from which to ply his trade.

Aside from its function as a staging of the Gothic's interests, the black mass can also be viewed as a perversion of the marriage festival that ought to conclude the

\footnotetext{
${ }^{63}$ Amis, Green Man 139, 235.

${ }^{64}$ Amis, Green Man 108.

${ }^{65}$ Frye 165.
} 
comedy. ${ }^{66}$ If we accept Seligman's claims for ritual as a response to a tragic real, then the comic marriage is a response to the fact that sometimes couplings fail; while the black mass is an imaginary response to the idea that sometimes marriage succeeds, limiting us to a life of social propriety and potential sexual moribundity. The black mass, as we have seen with Howatch and Amis, can function inside the comic text, creating a subjunctive world of sexual license and unacceptable behaviours. The threat it poses to comic narrative is its ability to destroy the suitability of a potential partner; neither Nicola nor Tanith would be marriageable in conventional comic terms if they became involved in the Sabbat's sexual congresses. The Green Man, however, is not interested in the moral absolutes of that kind of comedy. The pseudo-Sabbat it stages is not understood as wrong, as such.

The various Gothic manifestations that erupt into Maurice's life become a subjunctive, an alternative to his somewhat pathetic daily routine. The haunting interests him more than his own dysfunctional relationships and failing health. The Green Man at once invites us to become caught in its Gothic world while simultaneously resisting it, keeping, with Maurice, a sceptical, ironic distance from both Underhill's scheming projections and Christ's advice; nevertheless, with Maurice, we sometimes become swept up in the simple adventure of engagement with the Gothic.

\section{Two Tales from Dark Entries}

Amis must have known of Robert Aickman; Amis' second wife, Elizabeth Jane Howard, was romantically involved with Aickman in the fifties, and the pair published a book of short stories together, We Are for the Dark. However, Aickman never enjoyed the literary prestige of Amis, instead specialising in macabre tales that were literate without necessarily being literary. Aickman occasionally features the black mass in his tales and his 1964 collection of short stories, Dark Entries, features two of this sort, 'Bind Your Hair' and 'Ringing the Changes'. Where The Green Man is simultaneously involved in genre practices other than the Gothic, Aickman's tales

\footnotetext{
${ }^{66}$ Frye 163-4.
} 
tend to single-mindedly pursue the representation of, and opportunity for, Gothic experience.

Aickman is not an especially familiar name, even within Gothic studies. To date, the little work done on Aickman appears to have been undertaken by enthusiasts rather than academics. In his lifetime, he was noted more for his work for the Inland Waterways Association, championing the protection and restoration of Britain's canal system. His books Know Your Waterways and The Story of Our Inland Waterways were substantially more popular than his tales of the macabre; indeed, Know Your Waterways was reprinted five times by various publishers between 1955 and 1967, while his collections generally ran to only one or two printings. ${ }^{67}$ However, his stories have continued to enjoy a reputation amongst well-read fans of the macabre, and have been frequently anthologised. ${ }^{68}$ Michael Dirda regards him as 'a neglected master, a superb artist'. ${ }^{69}$ Aickman edited and introduced a successful line of ghost story anthologies for Fontana between 1964 and 1972, and in addition to his work in short form, produced two novels and an autobiography. He won the World Fantasy Award in 1975, and the British Fantasy Society Award in 1980, prizes indicative of his stature within the world of genre fandom more than any kind of mainstream literary success. He died in 1981, after a brief struggle with cancer. ${ }^{70}$ Aickman is now out of print and his books fetch considerable prices amongst collectors. It is a real shame that Aickman is close to falling into obscurity, as his tales are often excellent, offering quality prose and a knack for the pleasurably unsettling.

A contemporary review of Dark Entries published in the New Statesman noted the reviewer had been unable to finish the collection, complaining 'The first of his ghost stories left me cold. The second left me goose-fleshed. I have no intention of reading the remaining four, because I don't enjoy being frightened in this particular

\footnotetext{
${ }^{67}$ Gary William Crawford, "Robert Aickman: A Bibliography," Fantasy Commentator 9.2 (1997): 1434.

${ }^{68}$ Crawford, "Robert Aickman: A Bibliography," 144-6.

${ }^{69}$ Michael Dirda, "The Wine-Dark Sea," Bound to Please: An Extraordinary One-Volume Literary Education (New York: Norton, 2005) 237.
}

${ }^{70}$ Gary William Crawford, Robert Aickman: An Introduction, Gothic Chapbooks 7 (Baton Rouge: Gothic Press, 2003) 3-22. 
way... ${ }^{71}$ Sometimes the Gothic limits its audience by offering a performance of the genre more vigorous than many readers will feel comfortable with. However, this intensity, together with the quality of Aickman's writing, probably contributes to his cult status amongst fan readers who seek more enthusiastic stagings of the Gothic.

In 'Bind Your Hair', Clarinda Hartley accompanies her new fiancée, Dudley Carstairs, on a visit to his parents' house in Northamptonshire. The Carstairs are nice but dull, and Clarinda is more interested in the mysterious Mrs Pagani who calls by. On a midnight walk, she discovers a weird orgy atop a hill, which Mrs Pagani presides over. Clarinda is hidden in a bush by two strange children and observes the Sabbat before fleeing, only to meet with Mrs Pagani the next day. 'Ringing the Changes' is the story that caused the New Statesman's reviewer to abandon her reading. Gerald and his young wife Phrynne have opted to spend their late honeymoon in the East Anglian seaside town of Holihaven. Unluckily, their visit coincides with an annual festival where the townsfolk ring bells until they wake the dead, who then dance with the living. Gerald fails to follow advice to leave, and once the dance begins, the living and the dead invade the couple's room. Gerald is assaulted and Phrynne is swept up in the dance.

Both of the tales feature many of the Sabbat's now familiar elements, but occlude its meaning more completely than the texts so far discussed. The Sabbats presented by Wheatley and Howatch carry not so much meaning as sense; participants and observers understand the ritual as a coherent action. Likewise, readers are able to name the ritual, and can understand it as being 'what Satanists do'. Similarly, the elements of the black mass in The Green Man fulfil a comprehensible narrative function, forming part of Underhill's scheme. However, Aickman's rituals are literally mysteries. Readers never learn why the living must dance with the dead in Holihaven, or what Mrs Pagani's group are attempting in the middle of the night. In the texts discussed earlier, it is inappropriate to ascribe substantial discursive meaning to the mass; in Aickman, it is not only inappropriate, it is almost impossible. Perversely, this increased meaninglessness increases the pressure on the reader to ascribe meaning, to make sense of stories which are not sensible, producing the kind of reflective reading practice characteristic of literature as opposed to the Gothic.

\footnotetext{
${ }^{71}$ Brigid Brophy, "Critical Extracts," Modern Horror Writers, ed. Harold Bloom, Writers of English: Lives and Works (New York: Chelsea House Publishers, 1995).
} 
Aickman's introductions to the ghost anthologies he edited describe his view of the genre. While a 'ghost story' is a subcategory of the Gothic, Aickman was using it in an extended sense to describe narratives that did not necessarily feature the ghostly. Indeed, Aickman's own writings seldom feature anything as simple as literal ghosts, but were nevertheless described as 'ghost stories'. Dark Entries is no exception. For Aickman, the ghost story is the Gothic in a wider sense, but in a very different register to that associated with Wheatley's black magic stories.

Aickman argues the ghost story provides an escape from

a mechanistic world, ever more definable, ever more predictable, and, therefore, ever more unsatisfying and frustrating. As an antidote to daily living in a compulsorily egalitarian society, a good ghost story, against all appearances, can bring real joy. The reader may actually depart from it singing. ${ }^{72}$

Aickman's problem with the depredating encroachments of an 'egalitarian society' possibly aligns him with the kind of conservatism characteristic of Wheatley. His point reflects a combination of contemporary concerns, over the development of a society that genuinely was more mobile and less class-ridden, together with the rise of Harold Wilson's Labour party, which openly employed the rhetoric of socialism and progress, ${ }^{73}$ and a not uncommon belief that the nation was in a state of decline. ${ }^{74}$ Aickman's thesis remains; the Gothic story has always been an escape from the pressures of the modern. This, in fact, describes the Gothic as the exact opposite of what historicising critics claim it might be. Rather than pointing toward contemporary cultural anxieties, the Gothic text points away from them. The Gothic is an escape, involving the creation of a subjunctive world, necessitated by very real and

\footnotetext{
${ }^{72}$ Robert Aickman, Introduction, The Third Fontana Book of Great Ghost Stories, ed. Robert Aickman (London: Fontana, 1966) 7; qtd in Crawford, Robert Aickman: An Introduction 27-8.

${ }^{73}$ Morgan 134, 161.

${ }^{74}$ Dilwyn Porter, "'Never-Never Land': Britain under the Conservatives 1951 - 1964," From Blitz to Blair: A New History of Britain since 1939, ed. Nick Tiratsoo (London: Weidenfeld and Nicolson, 1997) 130.
} 
recognisable conditions. This thesis argues the genre is an entertainment; Aickman goes further, suggesting it is a balm. However, this is not necessarily because of any potential psychotherapeutic qualities the texts might hold, as is sometimes argued, ${ }^{75}$ although Aickman's claim may align itself with this approach. A further proviso is that this claim can only stand if the tale does not overwhelm its reader, as in the case of the New Statesman's reviewer.

Whether or not 'Bind Your Hair' overwhelms, it is a genuinely bewildering story, the polar opposite of Wheatley's explicit style, where the reader is never left wondering what is happening. Aickman loads figures and places with the weight of meaning, although said meaning is often unclear. This encourages the reflective reading appropriate to a literary text. However, unlike literary work, which tends to produce discourse even when it is ambiguous, Aickman's ambiguities are only lightly discursive.

Mrs Pagani, who seems to preside over the Sabbat, is a case in point. 'Pagani' suggests paganism. Her appearance at the desultory drinks function organised by the Carstairs, dressed in black, and dramatically dropping her fur coat on the floor, only increases the sense that she is unlike the other residents of Northamptonshire. She lives in a specially deconsecrated building in the village cemetery, and the next day, when she speaks to the peculiar redhead, Rufo, it is in a strange language that Clarinda thinks might be Romany. All of these things delineate Mrs Pagani as a witch. Yet when considered reflectively, these associations add up to little that is really meaningful beyond this point. We cannot tell if she actually is Romany, we do not learn what Rufo is meant to be, and the curious location of Mrs Pagani's house is not examined at any length. The witch's character and motives remain obscure. In a literary work, details like this might work towards a greater meaning, but in 'Bind Your Hair', they imprecisely infer rather than substantially suggest.

This obfuscatory imprecision is especially prominent in the recurrent motif of hair-binding. Whether or not a character's hair is bound seems to be developed into a meaningful binary, but what this binary might signify is utterly obscure. The detail is stressed throughout the tale, as if it were significant, but there is no further

\footnotetext{
${ }^{75}$ See, for instance, William Veeder, "The Nurture of the Gothic; or, How Can a Text Be Both Popular and Subversive?" Spectral Readings: Towards a Gothic Geography, eds. Glennis Byron and David Punter (Basingstoke: Palgrave Macmillan, 1999).
} 
explanation. Clarinda meets Mrs Pagani on an afternoon walk, and Mrs Pagani remarks on her hair. The exchange is typical of the way the detail is treated:

"You've bound your hair very well."

Clarinda had been noticing how carefully Mrs. Pagani’s own thick locks had been turbanned.

"It was getting wet."

Mrs. Pagani nodded and smiled. ${ }^{76}$

Clarinda does not reflect on Mrs Pagani's strange observation. Nor is the detail examined in the following episodes where hair is bound, or, finally, unbound.

When Clarinda observes the Sabbat, she must bind her hair. The hair of the participants is also bound. One of the tale's final lines describes Mrs Pagani's 'thick black hair [which] flew in the wind like a dusky gonfalon', 77 as if it were a meaningful detail, yet it is nothing of the sort. It holds the place of a signifier of real import, which might allow a meaningful reading of the story, but only confirms that the binary, bound and unbound, is operating, without providing sufficient information to attempt an interpretation.

The same sort of importance is attached to punctuality, and again, no easy meaning emerges. Mrs Pagani walks past the Carstairs' house as Clarinda and Dudley prepare to return to London, calling out, 'Don't be late' ${ }^{78}$ Mrs Pagani's final remark holds two potential meanings. To Dudley it must seem like a wish that he will not miss the train (he claims never to have missed a train in his life). To Clarinda, it must be more sinister: she is to return to another celebration, and this time, she cannot be late. She will have to participate rather than simply observe. Exactly why punctuality should be loaded with import is unclear, but these details are not perhaps as baffling as they could be; even if we do not understand them, they carry a folkloric resonance. We cannot necessarily tell why peculiar actions repeated in folktales are important, but we nevertheless feel that their repetition 'makes sense'.

\footnotetext{
${ }^{76}$ Robert Aickman, "Bind Your Hair," Dark Entries (London: Collins, 1964) 161.

${ }^{77}$ Aickman, "Bind Your Hair" 173.

${ }^{78}$ Aickman, "Bind Your Hair" 173.
} 
The story's conceit is, in some ways, comic. Clarinda seems to have been mistaken for someone or something else. When Clarinda encounters Mrs Pagani while out on her walk, she reflects 'Not for the first time... that Mrs. Pagani implied some understanding between them which did not exist. ${ }^{79}$ Mrs Pagani, and later, the pair of strange children, recognise her as something she is not, and consequently treat her as an initiate of their mysteries. When Clarinda finds the midnight revellers, she finds herself in the company of the two children. The girl expects her to have knowledge that she simply does not, and tries to accommodate Clarinda as she 'behave[s] in quite the wrong way. 80

However, the more significant misidentification of Clarinda has been made by the Carstairs. Mrs Pagani recognises Clarinda as a participant in the Sabbat, and, at the conclusion of the tale, this seems possible. However, Clarinda is not the woman her fiancée believes she is. She would like to sleep with Dudley, but, true to his name, he is passionlessly unaware of Clarinda's desire, and as she awakes in the Carstairs house after her first night there, she

had to admit to herself that she was very depressed... she felt that inside the house was a cosy emptiness in which she was about to be lost... for ever suspended in blackness, howling in the lonely dark... while her other, outer self went smiling through an endless purposeless routine of love for and compliance with a family and community of friends... exceedingly unlike her... ${ }^{81}$

The Carstairs, who occupy themselves with uninspiring activities and ensure they are in bed early, are representatives of the mechanistic, predictable, unsatisfying world that Aickman fears. Clarinda resists this world and consequently finds herself an

\footnotetext{
${ }^{79}$ Aickman "Bind Your Hair" 161.

${ }^{80}$ Aickman, "Bind Your Hair" 167.

${ }^{81}$ Aickman, "Bind Your Hair" 152.
} 
outsider in Dudley's family. She becomes 'aware that she might have some difficult personal problems almost immediately ahead of her' ${ }^{82}$

Clarinda may have to break off her engagement, rejecting the Carstairs' small town insularity and lifelessness. Indeed, as soon as she leaves the Carstairs' house to take a walk in the rain, an act that troubles her hosts, Clarinda 'felt alive again' by virtue of her absence from the family. ${ }^{83}$ Mrs Pagani's world, on the other hand, is frighteningly lively. When Clarinda decides to leave the house a second time, the night is teeming with life. A bat tries to enter her bedroom, in the best Gothic fashion, before she appreciates the distinctly Gothic beauty of the scene outside:

Clarinda softly shivered for a moment, then watched the bat skid into invisibility. The silver-gilt autumn night was somehow warmer and more welcoming than Clarinda's unadventurous bed; fellow-bed, twin-bed to a thousand others in a thousand well ordered houses. The grave self-sufficiency of the night was seeping into Clarinda's bloodstream, renewing her audacity, inflaming her curiosity; and its moonlit beauty agitating her heart. By the light of the big moon she began to dress. ${ }^{84}$

A note of sexual anxiety is struck; and the invigorating appeal of the night, described in Romantic terms, is as apparent to the reader as it is to Clarinda. Within moments of leaving the house, she nearly trips on a hare, and is out amongst the owls and moths. Aickman's tale operates in a very different way from the Wheatley or Howatch narratives. While the reader might feel a salacious interest in the activities of any of the worshippers described, Wheatley's and Howatch's characters reject the aesthetic and values they represent. Clarinda, however, feels the same attraction to nocturnal beauty that the Gothic reader might. Clarinda's shift away from the humdrum life of a Northamptonshire village and interest in the liveliness of the night represents the shift from everyday habitus into Gothic practice. The readerly interest in the Gothic is

\footnotetext{
${ }^{82}$ Aickman, "Bind Your Hair" 154.

${ }^{83}$ Aickman, "Bind Your Hair" 153-4.

${ }^{84}$ Aickman, "Bind Your Hair" 165.
} 
endorsed by Clarinda. The night provides a subjunctive alternative to the dreary commonplace of Dudley's family. This subjunctive world is extended and formalised in the Sabbat itself.

Clarinda is another Sabbat voyeur, spying on the revels from within the foliage of a bush. However, the ritual is not presented in the technical detail that characterises Wheatley's. Sacrifice is absent, and there is no figure present with the mythical dimensions of the devil, which further complicates any attempt to define what is happening. Clarinda watches as

all over the maze, under the moon, writhed and slithered and sprawled the smooth white bodies of men and women. There were scores of them; all apparently well-shaped and comely; all (perhaps for that reason) weirdly impersonal; all recumbent and reptilian... ${ }^{85}$

While this hardly qualifies as straightforward erotic beauty, it is nowhere near as grotesque as the earlier Sabbats. Any sort of moral assessment of the scene is withheld. The nudes are impersonal rather than specifically individualised, comely rather than disfigured. Clarinda does not interrupt the Sabbat, although she does flee before it reaches a climax.

This presentation of the Sabbat is quite different to others current in the field. The rite is not condemned as wicked, nor is it easily legible as a salaciously exciting countercultural event. Rather, by withholding the suggestion of either of these easy readings, Aickman returns Clarinda, and his reader, to the simple actuality of the strange tableau. In the absence of an obvious reading, we do not quite know how to respond. As with the hair-binding, Clarinda's reaction to this scene is largely occluded. She flees, not because she fears becoming a participant at this point, nor because the Sabbat is threatening, but because the strange little boy, who may in fact be a dwarf, has bitten her.

Again, this encourages readers to shift into a reflective, literary reading practice, as they attempt to decipher the meaning of the Sabbat. However, there are

\footnotetext{
${ }^{85}$ Aickman, "Bind Your Hair" 170-1.
} 
few clues with which to guide an interpretation. We never learn what Clarinda makes of the Sabbat, but if the Carstairs stand for suburban deathliness, then the strange rite stands in opposition to their moribund world, suggestive of a livelier, perhaps 'unbound' way of being. Mrs Pagani lives in a converted chapel in the churchyard. In a way, this illustrates the differences between the metaphorically dead Carstairs and the spirited witch. Mrs Pagani lives alone but alive amongst the dead. The Gothic figure of the witch presents an exciting escape from everyday convention, an alternate way of being more than a threat to Clarinda.

However, this provisional interpretation is hopelessly complicated by the details surrounding the Sabbat. Clarinda has earlier encountered a mob of pigs, joined by a great boar. The maze where the Sabbat occurs is located next to a building apparently dedicated to their care, and the participants shed some kind of fur as they enter into it. Clarinda is pressured to 'change' by the girl, but is unable to do so. Who are the participants? Are they the pigs, somehow transformed? What are we to make of the girl and the dwarf? What of the absurdly sinister Rufo, also present at the Sabbat? What is his relationship with Mrs Pagani? 'Bind Your Hair' takes its reader to the performance of a mystery rite but is in itself a mystery of sorts. There can be no authoritative reading. Neither Clarinda nor the reader is initiated into its meaning.

Aickman was interested in Freud. We could suggest that Dudley, aptly named, has already sexually disappointed Clarinda, yet she is to be married to him. In the course of the narrative she encounters both a hyperbolised sexual rite, perhaps relating to her anxiety over entering the nuptial bed, and the child-like figures, the possible consequence of her impending marriage. The Sabbat suggests relations between Clarinda and Dudley, while simultaneously suggesting the potential satisfactions and partners that Clarinda's id will be forgoing; it proposes the idea of a satisfactory sexual life at the same time as negating it. It is significant that Clarinda should be attacked by one of the children, suddenly revealed as other than a child, at this point. If Clarinda does not break off her engagement, she faces sexual dissatisfaction, motherhood, and her own desires becoming sublimated to the superegoic demands of Dudley, the Carstairs, and possibly, children. We might argue that the Sabbat is nothing more than a hallucination, a projection of Clarinda's repressed desires. This reading has much in common with 'psychological' readings of 'The Turn of the Screw'. However, a Freudian reading begins to struggle under the sheer number of 
seemingly significant but basically oblique details: red-headed Rufo, hair-binding, punctuality, the swine, and so forth.

Despite the confusions attendant on a Freudian reading of 'Bind Your Hair', Aickman unambiguously linked the ghost story to psychoanalytic theory:

Dr. Freud established that only a small part, perhaps one-tenth, of the human mental and emotional organization is conscious... The trouble, as we all know, is that the one-tenth, the intellect is not looking after us: if we do not blow ourselves up, we shall crowd ourselves out; above all, we have destroyed all hope of quality in living. The ghost story, like Dr. Freud, makes contact with the submerged nine-tenths. ${ }^{86}$

That the Gothic has a special relationship with psychological depth has become something of a truism for Gothic studies, and Aickman here treats the practice as a form of psychoanalysis. This thesis argues against that privileged relationship, but we can still recognise that in cases like Aickman's, the author is especially interested in psychoanalytic theory, and that it informs tales like 'Bind Your Hair' and 'Ringing the Changes'. It is worth noting that Aickman's claims for the psychoanalytic significance of the Gothic precede the claims that the academy would make for Gothic fiction by ten or fifteen years. However, where psychoanalysis aims to provide some kind of understanding when the unconscious is consciously examined, Aickman's tales do not necessarily provide their readers with the tools with which to process this contact. Just as important is Aickman's expectation that readers deploy a different reading strategy from Wheatley's, encouraging them to reflect and analyse.

'Ringing the Changes' touches on some of the ideas developed in Beyond the Pleasure Principle, specifically the close intermingling of sexuality with death, although this is, of course, a knot in the threads of Western thought which long precedes Freud. In Beyond the Pleasure Principle Freud opens his discussion of the

\footnotetext{
${ }^{86}$ Robert Aickman, Introduction, The Fontana Book of Great Ghost Stories, ed. Robert Aickman (London: Fontana, 1964) 7; qtd. in Crawford, Robert Aickman: An Introduction 23.
} 
death-drive with a consideration of the compulsion to repeat. ${ }^{87}$ On the night of Gerald and Phrynne's visit, Holihaven is seized by just such a compulsion, the town's bells being rung all evening and through at least until midnight, perhaps later. ${ }^{88}$ Freud's essay links the compulsion to repeat to the notion of a death drive, which is, in turn, twinned with the pleasure or sexual principle. He suggests that sex and death instincts exist in all complex living organisms, that they move through our lives in a vacillating rhythm, and that these principles struggle within us; yet at the same time, the "pleasure principle seems actually to serve the death instincts. ${ }^{, 89}$ Gerald and Phrynne's honeymoon night is interrupted by the danse macabre; at the moment that ought to be given over to pleasure and, potentially, the creation of new life, death intervenes. One drive is cuckolded by another.

Only characters that do not or should not participate in the dance are treated in any detail in the text, and the narrative does not account for why Phrynne should be the only one amongst them who becomes a participant. The Commandant, the only other guest at their hotel, tells Gerald that 'women are creatures of darkness', seeming to suggest an association between female sexuality and death. ${ }^{90}$ The dance itself seems to celebrate the interrelationship of the sex and death drives.

In the light of Aickman's claims for the function of the ghost story, it is easy enough to construct an argument for the involvement of his text in an investigation of these drives, an allegorical form expressing particular psychoanalytic tenets. However, despite the potential held by 'Ringing the Changes' for an allegorical reading, it remains resistant to interpretation. While the dead and living dance, they sing

"The living and the dead dance together.

\footnotetext{
${ }^{87}$ Sigmund Freud, Beyond the Pleasure Principle, trans. James Strachey (New York: Liveright, 1961) $16-7$.

${ }^{88}$ Robert Aickman, "Ringing the Changes," Dark Entries (London: Collins, 1964) 51.

${ }^{89}$ Freud 34-5, 40, 54-5, 57.

${ }^{90}$ Aickman, "Ringing the Changes" 50. It is worth noting that Aickman's stories frequently, perhaps even typically, feature mysterious, unknowable women.
} 
Now's the time. Now's the place. Now's the weather."91

Rather than emphasising the potential for allegorical meaning, the couplet underlines the ritualistic force of the moment. The words hold nothing additional in terms of meaning or information. As Gerald looks on, the whole of this statement is already apparent. The chant only serves to emphasise the presentness of the moment. There is only the dance, in the here-and-now. It cannot be comprehended by Gerald, who, again, is caught as a non-participating voyeur. However, Gerald's voyeurism is limited in that he is overwhelmed and does not observe the dance once his wife has joined it.

In ritual, 'performing the act marks the acceptance of the convention' 92 and facilitates entry into a subjunctive state. The revellers enter their room and Phrynne enters the dance; 'Phrynne was hysterical. All self-control gone, she was scratching and tearing, and screaming again and again. ${ }^{93}$ Like Wheatley's Satanists, she has entered an animalistic state. She becomes swept up in the dance at the moment that her self-control, her human agency fails. Phrynne moves beyond the limits of her own ego, or the limits of the sincere, and enters a state of negative ecstasy that facilitates her participation in the ritual's communal action. Gerald, however, is unable to join her in that state. In part, this is because he has been manhandled, but more significantly, he does not escape his own subjectivity. Where Phrynne's response to the catastrophic weirdness of the dance is to join it, Gerald retreats within his own psyche, sincere, but paralysed by his sincerity, excluded from the subjunctive world Phrynne has entered.

Unlike Wheatley's heroes, impotent Gerald is not endowed with the extraordinary agency that would allow him to interrupt the Gothic ritual. The Commandant, an authoritarian older man not unlike a much-reduced de Richlieu, is, however, able to enter into the danse macabre and retain his own sincerity. He retrieves Phrynne, but not before the rite has changed her permanently. On her return to the hotel, Phrynne outrages Mrs Pascoe, the proprietor, by taking off the coat she

\footnotetext{
${ }^{91}$ Aickman, "Ringing the Changes" 62. Italics in original.

${ }^{92}$ Seligman, Weller, Puett and Simon 24.

${ }^{93}$ Aickman, "Ringing the Changes" 62.
} 
has been offered so that she is almost naked in her torn nightdress. It is difficult to ascertain Phrynne's motive for the odd gesture, but by raising the spectre of sexuality at this point, the text infers that there was a physical, even sexual element in the dance of death. Unlike the Sabbats described above, Holihaven's dance has a lasting effect; a change has been rung.

The next morning, as the unhappy newlyweds depart Holihaven, they notice the townsfolk restoring the cemetery to an ordered state. The scene horrifies Gerald, but Phrynne reacts differently. Her

cheeks reddened and her soft mouth became fleetingly more voluptuous still... Then, once more, she became herself. In those previous seconds Gerald had become aware of something dividing them which neither of them would ever mention or ever forget. ${ }^{94}$

The sexual element of the previous night's dance is underlined. Phrynne's recall of the event seems to be erotically charged. Gerald remains confined to his role as a voyeur. The Sabbat makes Gothic experience visible. At the conclusion of 'Ringing the Changes', Gerald recognises that the Gothic experience Phrynne has participated in persists in some way.

'Ringing the Changes' is in some ways a better emblem of the Gothic than Wheatley's Sabbat. Wheatley presents the ritual practice of his Satanists as abhorrent, actually criminal, and entirely hidden, discovered only by clever voyeurs. All the inhabitants of Holihaven, however, understand the danse macabre, although a handful, including the Commandant, refuse to participate. There is no attempt to conceal the dance, although it is limited in that it is only appropriate at a certain time, and only lasts for a certain period. The dance is exultant, but is difficult to attach meaning to much like the ringing of the bells that precedes it.

The Sabbat appeared frequently enough in the contemporary Gothic to have acquired the inevitability of ritual, although differences remain. The Sabbat manifests quite differently in 'Bind Your Hair', but, as in 'Ringing the Changes', it is presented as being so obscure that any substantial interpretation potentially strays into

\footnotetext{
${ }^{94}$ Aickman, "Ringing the Changes" 65.
} 
overinterpretation. We can only recognise its significance rather than its meaning, its function rather than its purpose. However, these Sabbats remain analogues of the Gothic reading act. 'Bind Your Hair' explicitly presents the lure of the Gothic as an escape from banality, and suggests that the difficulty this presents is that Clarinda, and the Gothic reader, may wish to return to this subjunctive space, as if the subjunctive were a tenable alternate for the real. In 'Ringing the Changes', Phrynne's ability to participate in the subjunctive of the Holihaven dance marks her apart from Gerald. Gerald perceives this as a troubling difference, worrying that this is a dangerous, permanent change rather than a limited ritual event. Rather than undermining the argument that the Gothic is an entertainment, however, this weirdly emphasises it. We pretend the Gothic text is loaded with threat and there might be something dangerous in our participation, when really, like the New Statesman's reviewer, readers simply withdraw their commitment to the game when it is no longer pleasurable.

\section{The Gormenghast Trilogy}

David Punter's assessment of Mervyn Peake's The Gormenghast Trilogy remains astute; it is a fantasy composed out of 'the elements of early Gothic fiction'. ${ }^{95}$ As with Wheatley's black magic stories, it was not composed in the sixties, but instead found its audience towards the end of that decade, but unlike Wheatley, has retained a popular readership.

The Trilogy features versions of the black mass, albeit tucked away in its less well-known corners. In fact, the Trilogy is interested in ceremony in a wider sense, presenting the social world of castle Gormenghast in careful detail, a place shaped by obscure ritual practices that have lost much or all of the meaning they once held. In one case, the narrator tells us that 'It was not certain what significance the ceremony held, for unfortunately the records were lost, but the formality was no less sacred for being unintelligible. ${ }^{96}$ The rituals of Gormenghast have become absurd. Both Titus,

\footnotetext{
${ }^{95}$ Punter, Literature of Terror 4.

${ }^{96}$ Mervyn Peake, Titus Groan, 1946, The Gormenghast Trilogy (London: Vintage, 1999) 213.
} 
the young earl supposed to inherit the castle's governance, and the usurper Steerpike attempt to resist its demands of them. Steerpike reflects that 'It was time for the dirty core of ritual to be plucked out of the enormous mouldering body of the castle's life and for him to take its place... ${ }^{97}$ This resistance leads to Steerpike's attempt to control the ceremonies himself, and ultimately, his downfall. Titus instead flees, abdicating his crown and excusing himself from further participation in dead ritual.

One of the remarkable things about Titus Groan and Gormenghast is their scale. Aickman is typical of the contemporary field, in that he was working in the shorter form. Wheatley and Howatch, although working at novel length, are meant to be read rapidly. The duration of the reading experience offered by Peake's Gothics sets them apart as much as anything else. Peake's tortuously precise prose and distant characters offer something closer to a study than a ripping narrative. The reading experience offered by the Trilogy is significantly different to that offered by the other Gothics present in the field.

Initial responses to 1946's Titus Groan saw it as being timely and of substantial literary worth. Many critics were generous in their assessments; Quentin Crisp apparently celebrated Peake as a genius greater than Blake. ${ }^{98}$ Responses to 1950's Gormenghast were again generally favourable, but even as the first two books received critical plaudits, they missed out on popular success until almost twenty years after their initial publication. ${ }^{99}$ Despite the limited initial success they enjoyed, sceptics remained; Kingsley Amis dismissed Peake 'as a bad fantasy writer of maverick status'. ${ }^{100}$ Many American reviewers simply dismissed the Trilogy, 'having sought in vain for a meaning to the book., 101

\footnotetext{
${ }^{97}$ Mervyn Peake, Gormenghast, 1950, The Gormenghast Trilogy (London: Vintage, 1999) 493.

${ }^{98}$ John Batchelor, Mervyn Peake: A Biographical and Critical Exploration (London: Duckworth, 1974) 81.

99 John Watney, Mervyn Peake (London: Michael Joseph, 1976) 160-1.

${ }^{100}$ Qtd. in Michael Moorcock, Foreword, Vast Alchemies: The Life and Work of Mervyn Peake, by G. Peter Winnington (London: Peter Owen Publishers, 2000) n.pag.

${ }^{101}$ G. Peter Winnington, Vast Alchemies: The Life and Work of Mervyn Peake (London: Peter Owen Publishers, 2000) 186.
} 
The Trilogy, set quite apart from our world, opens itself to interpretive reading practices. Colin Manlove notes Steerpike's rise broadly parallels the situation in Europe between 1930 and 1945, and that Titus Alone presents 'a more general parable of social and domestic change between 1940 and $1960 .{ }^{102}$ Steerpike comes to a position of power through demagoguery, and burns books when he torches the library. Eventually, in the near-apocalyptic conditions of the deluge, a kind of war is declared. Manlove's is an obvious reading, but hardly an essential one, unlocking little for the reader. There is scant evidence that this is what Peake was aiming at either; he explicitly hoped to produce a work apart from his everyday world of ration-books and bus queues, but something unique and entirely apart, something mythic. ${ }^{103}$ For Peake, un-worldliness becomes a response to the world; escapism is not necessarily an opting-out, but a response or even redress to the privations of the war and afterward.

Peake was championed throughout the sixties by influential science fiction editor Michael Moorcock, ${ }^{104}$ but it was not until the Penguin Modern Classics editions of the first two books appeared in late 1968 that the work found its audience. As John Watney notes, they found cult success similar to Tolkien's; 'Young men and women on the road to Katmandu would have "a Peake" in their knapsacks." ${ }^{105}$ With this belated success came a general re-engagement with the Trilogy. 1969 saw the premiere of Tim Souster's Titus Groan Music, an experimental piece for tape and wind quintet at the Camden Festival; ${ }^{106}$ when one text forms the basis for another, it suggests the primary text has achieved a degree of prestige in its field. Interestingly, by the time the Trilogy found a popular audience, critical appreciations of the texts had been substantially modified. No longer regarded as being engaged in contemporary discourse, Titus Groan was seen as pure fantasy. ${ }^{107}$

\footnotetext{
${ }^{102}$ Colin Manlove, The Fantasy Literature of England (Basingstoke: Palgrave, 1999) 151.

${ }^{103}$ Winnington 169-70.

${ }^{104}$ Winnington 222.

${ }^{105}$ Watney 242.

${ }^{106}$ See Robin Thompson, rev. of "Tim Souster's Titus Groan Music," Tempo New Series. 89 (1969) 21 2.

${ }^{107}$ Paul Green, New Statesman, 26 January 1968; qtd. in Batchelor 81-2.
} 
In fact, the Gormenghast Trilogy is something of a misnomer, and I use it here to include more than three texts. The Trilogy was intended as a cycle of perhaps five books, of which only three were completed. However, there is a fourth published Titus text, Boy in Darkness, that exists outside of the major novels, originally appearing in a commissioned collection featuring John Wyndham, William Golding and Peake in 1956. It orbits the main mass of the texts like some weird, seldom-spied moon. It too was republished, in 1969, as part of another collection, to keep pace with the newfound enthusiasm for Peake's work. ${ }^{108}$ However, even as the Trilogy found its audience in the late sixties, the last instalment we have, Titus Alone, was not reprinted, leaving it obscure.

Titus Alone exists in two forms. Originally substantially cut by its publishers in 1959, it was restored by editor Langdon Jones at the urging of Moorcock in 1968. ${ }^{109}$ Titus Alone turns away from the first two novels, abandoning the world of castle Gormenghast in favour of Titus' sojourn in a strange, dystopian, futuristic yet recognisably modern country, the stuff of science fiction rather than castle Gothic. Aside from presenting a very different world in the third book, Peake was in the early stages of Parkinson's disease as he wrote it, and even with editorial intervention there is an unsettling sense that we can see his mind coming apart on the page.

Jones sensitively allows for Peake's degeneration when he writes that 'Had Peake been able to continue there is no doubt that he would have polished the story still more. ${ }^{110}$ Yet it is more than polishing the text needs. Where the first two novels carefully detailed a social world and the characters that populated it, Titus Alone presents inscrutable characters driven by unguessable motivations in an inexplicable place. Titus himself becomes a distressed stick figure, and the physical world, so precisely articulated in the first two books, loses focus. While Titus Alone represents the final instalment of the trilogy, it is of sufficiently different tenor to be considered separately, taking on the properties of science fiction as much as fantasy or the

\footnotetext{
${ }^{108}$ Watney 243.

${ }^{109}$ Watney 236.

${ }^{110}$ Qtd. in Publisher's Note, The Gormenghast Trilogy (London: Vintage Books, 1999) 758.
} 
Gothic, although it is worth recalling Amis' loose connection of these three genres, ${ }^{111}$ suggesting the three practices overlap to some degree.

A major difference between the Trilogy and other texts in the field is that it does not depict contemporary England; if readers see this in Gormenghast, it is an act of interpretation rather than a direct representation. The castle is worked out in extensive detail, as if the House of Usher were a place with a developed society and an ongoing life. Manlove argues that a common type of fantasy is the 'secondary world', where the text describes a world unlike our own. ${ }^{112}$ The Trilogy is a fantasy of this sort. Secondary world fantasy suggests the creation of a subjunctive world; it is 'as if' there is such a place as Gormenghast. Of course, it is possible to argue that almost any fictional world is subjunctive; readers engage in a practice where it is 'as if' certain characters exist and certain events occur. This is a potential challenge to this chapter's argument that a subjunctive world is created in the Gothic text's presentation of the black mass; if all fiction creates a subjunctive, how is the black mass different?

There are significant differences between the subjunctivity of mimetic fictionality in general and the specific subjunctivity of the black mass. The mass exists as a subjunctive world within the already fictional world, and thus can be thought of as holding a nested and greater subjunctivity (however, this is not to claim that the degree of subjunctivity is what characterises the Gothic in general, as the character of the Sabbat's subjunctive is a better identifier of the genre). Secondly, the Gothics of the era are structured so as to culminate in the black mass, as if the narrative were a procession towards it; the subjunctivity of the mass arranges narrative in a way that exceeds a more general subjunctivity arising out of fictionality. One of the ways that the Trilogy distinguishes itself from the Gothic texts that were also being consumed in the sixties is that while they proceed from a mimetic view of a world much like our own towards the creation of a distinct subjunctive, the whole of the Trilogy's secondary world is subjunctive in a way that exceeds the subjunctivity of mimesis. This is different from the subjunctivity of general fictionality in that the degree of hypotheticality is greater. It is possible that a drunken landlord or a pair of

\footnotetext{
${ }^{111}$ Amis, New Maps of Hell 17, 19, 21, 27, 57-8.

${ }^{112}$ Manlove.
} 
newlyweds exist, even if Maurice Allington or Gerald and Phrynne do not; it is not possible that a figure like Titus or a place like Gormenghast ever has.

These distinctions result in the Trilogy being a very different sort of text to the other Gothics discussed. The other Sabbats propose a binary, where recognisably 'normal' life is upset by the subjunctive world of the mass; in Peake, there is nothing normal in the same sense to disturb. Castle Gormenghast is an alien society, and hosts the performance of endlessly iterated rites, from which all meaning has vanished, presided over by the zealous Librarians, first Sourdust, then the maniacal cripple, Barquentine. The narrative opens with news of the birth of Titus, who will inherit the Earldom. However, with the introduction of Steerpike, disturbance of a different nature emerges. Having escaped from the kitchens, he begins to infiltrate the upper echelons of the castle's society, before turning to murder. The latter part of Gormenghast details Titus' hunt for the usurper. While the first two books are solidly plotted, this particular episode is the only part of the Trilogy that encourages fast reading, where the question 'what happens next?' is likely to acquire urgency for readers. For the majority of the narrative, suspense is incidental, and a summary of the narrative would not begin to suggest the reading experience. It is hard to disagree with Peter G. Winnington when he argues 'any summary of the Titus books misses the whole point, for it is obliged to omit the purely descriptive passages and neglects the interpenetration of person and place. ${ }^{, 13}$

Narrative stages the Gothic experience for readers, leading us towards mystery, dread, forbidden desire, and so forth. The procession towards the black mass is typical of this staging. Peake borrowed more than his setting from the eighteenth century Gothic, and the narrative style of the first two books is a throwback to Radcliffe. Radcliffe's plots were complex and worked out in substantial detail, as are Peake's, yet there are significant differences. Radcliffe's plots defer the release of information and encourage her readers to invest their interest in her heroine (what is Montoni planning? Where is Valancourt? What did Emily see behind the veil?) The function of the plot in Gormenghast is rather different. We are availed of everything; Steerpike's schemes, Swelter's plotting against Flay, where the twins have been shut up. Information might be withheld from other characters, but it seldom is from

\footnotetext{
${ }^{113}$ Winnington 128.
} 
readers. While Gormenghast is a place where dark secrets belong, nothing is hidden there, certainly not for the reader. The plot mirrors the architecture of the castle. It is massive, muddled, described in precise detail, but remains decorative rather than strongly affective. As Winnington notes, 'What undermines the Gothic in Mervyn's writing is the sense of distance that he creates, anaesthetizing the horror'. ${ }^{114}$ Where the Sabbat narratives lead towards an emblemized, involved and possibly affecting Gothic act, Titus Groan and Gormenghast do not use Gothic performance as a culmination. As we will see, however, both Boy in Darkness and Titus Alone do.

The Trilogy does, in fact, feature two performances that can be regarded as black masses. Additionally, there are moments that echo the performative elements of the black mass, where macabre occurrences are presented as spectacle. Steerpike's wild dance around the dead twins would be an instance of this, as would Sepulchrave's death by a parliament of owls.

Sepulchrave's death, the conclusion of a protracted mania where he apparently believes himself an owl, is more strange than shocking. Flay watches his master's fate from outside the action, after Sepulchrave has dragged the remains of Swelter into the Tower of Flints, claiming that he is going to offer it to 'them'. ${ }^{115}$

Everything was moving round and round - the Tower, the pines, the corpse, the moon, and even the inhuman cry of pain that leapt from the Tower's throat into the night - the cry, not of an owl, but of a man about to die. As it echoed and echoed, the lank and exhausted servant fell fainting in his tracks, while the sky about the Tower became white with the lit bodies of circling owls, and the entrance to the Tower filled with a great weight of feathers, beaks and talons as the devouring of two incongruous remains proceeded. $^{116}$

\footnotetext{
${ }^{114}$ Winnington 187.

${ }^{115}$ Peake, Titus Groan 319.

${ }^{116}$ Peake, Titus Groan 320.
} 
As with the Sabbats, Sepulchrave's individuality has been overwhelmed, and he has become one of 'them', although this is a more literal transformation into beast than that threatened in the satanic revels, and it is a fatal one. However, unlike the investment that readers might have in Tanith or Nicola being spared the depredations of the Sabbat, Sepulchrave's passing is unlikely to excite much in the way of fear or pity.

Flay, the voyeur, faints away, but we nevertheless witness the Earl's doom. The Tower merges with the pines, Swelter's corpse with the moon, and all are united by Sepulchrave's cry, which comes from the 'throat' of the Tower, as if the castle itself had voice, further merging character and environment. Odd contraries abound. The dark sky turned white by the lit bodies of the owls is a visual coup, while feathers, which ought to be light, are given a 'great weight', a further sensory disorientation. The Earl is reduced to a 'remain' alongside Swelter, 'incongruous' presumably because he is not dead, only dying, or perhaps because Sepulchrave is very thin, while Swelter is massively fat. Everything in the scene is 'moving round and round', inconstant and uncertain. The most ludicrously Gothic scenario possible is depicted, yet it remains playful and spectacular rather than genuinely disturbing.

Taken alone, the death of the Earl seems like the consequence of some profound crisis, a Gothic climax. However, where the black mass typically forms an exception, an aberration to the world as it ought to be, Sepulchrave's death amongst the owls seems not to hold this exceptionality. It is not banal, but neither is it entirely remarkable within the secondary world of the castle. His death is consistent with the way the world of Gormenghast works. Where the black mass functions as a contrast to the everyday world into which it irrupts, the owls seem to fall within the horizon of expectations described by Gormenghast.

Both Titus Alone and Gormenghast present life within the castle as choked by overgrown and withered ritual. However, in Boy in Darkness and Titus Alone, variations on the black mass are performed, and, unlike the castle rituals these rites are potentially efficacious. As is the case with most of the black masses discussed, they must be stopped.

Titus Alone presents a largely discontinuous secondary world from that of the novels that go before. Quite aside from the sense that it is not as carefully realised as the first two books, it depicts a technologically advanced, culturally modern, brave 
new world, in which Titus is 'a sudden visitant from nowhere'. ${ }^{117}$ Gone is the nostalgic evocation of half-forgotten Gothic texts, replaced by a world that draws from dystopian science fiction. One of the first set pieces features Titus falling through a skylight into the midst of Lady Cusp-Canine's cocktail party, landing amongst the bon mots of urban sophisticates, a scene unimaginable in the earlier books.

Where the two earlier books describe an imaginary society in intricate detail, here an imaginary society is proposed, but remains obscure to both Titus and the reader. In Titus Groan, we understand even how the kitchens of the castle are organised, the roles of the kitchen boys and the Grey Scrubbers; in Titus Alone it is difficult to understand who central figures like Muzzlehatch and Juno are and what they do, let alone how minor characters might relate to them. The first two books are characterised by the detailed sense of place they create, both in a physical and social sense. The third has lost interest in describing this specific placement of architecture and people. It is not possible for Titus to belong in this world, in part because it is not described in sufficient detail to create any sense of place.

A useful example of the different 'feel' of the world and the ambiguities which confront both Titus and the reader comes after Titus destroys the robotic globe that briefly pursues him. Muzzlehatch is able to name with exactitude the thing that Titus has destroyed, 'number LKZ00572 ARG 39576 Aij9843K2532 if I remember rightly. ${ }^{118}$ The language of code and bureaucracy suggests an impersonal world of machines and complex power structures. At the same time, the title is meaningless, telling us everything and nothing. Castle Gormenghast is a place of absent secrets, but the modern world of the third book, where so much seems to be on display, is, contrarily, much more troublingly mysterious.

If the first two books are not so much contemporary Gothics as reminiscences of what the genre once was, much of the third barely engages the practice at all, and is substantially bleaker in tone, evoking a contemporary European zeitgeist that has more to do with Camus than Walpole. The causes for many of the actions that drive the plot have been obscured, so that characters and narrative appear to be arbitrary

\footnotetext{
${ }^{117}$ Mervyn Peake, Titus Alone, 1959, The Gormenghast Trilogy (London: Vintage Books, 1999) 764.

${ }^{118}$ Peake, Titus Alone 834.
} 
and purposeless. Most significantly, we do not know why Muzzlehatch's animals are slaughtered, the act which drives his quest for vengeance, nor why the scientist's daughter, Cheeta, must exact such an astonishingly elaborate revenge on Titus for spurning her advances. Nevertheless, the action builds towards Muzzlehatch's destruction of the scientist's factory, and Cheeta's performance.

Cheeta presents a bizarre pantomime at the isolated Black House, recreating Gormenghast for Titus. Titus Alone is at its most strained here, dangerously close to losing coherency altogether. Characters appear and then not so much disappear as fade or become inert. While hyperbolic speech is commonplace in the Trilogy, here the dialogue loses clarity while increasing in complexity.

Cheeta, who is able to recreate the life of the castle because she has overheard Titus' delirious ravings recalling his home, scripts the performance. This mimics the action of Gormenghast, where Steerpike gives himself away to Prunesquallor as he deliriously raves after murdering Barquentine. ${ }^{119}$ The performance is also a repetition; Cheeta leads Titus, blindfolded to an event staged in his honour, a surprise, where he is enthroned so as to view the spectacle. This repeats the procedure of the masque that honours Titus' tenth birthday in Gormenghast. ${ }^{120}$ John Batchelor, one of Peake's earliest serious critics, characterises the Black House performance as a black mass. ${ }^{121}$ We might recall that the black mass is the parody of a ritual as much as it is a ritual, and the action of Titus Alone seems to parody the action of Gormenghast.

Gormenghast's secondary world complicates the notion of a black mass. There, librarians occupy the place of a priestly class, and Christian practice is exchanged for the interminable rituals of the castle. There is no Christian mass to parody. While Aickman's Sabbats, and especially the danse macabre of 'Ringing the Changes', are not linked to diabolism, Christian celebration remains a notional possibility in their fictional world, and the church is recalled through Mrs Pagani's residence and the bells of Holihaven. The rituals of Gormenghast can potentially be read as spoofs of the ceremonies of English church and state. Cheeta's black mass is a parody of a parody.

\footnotetext{
${ }^{119}$ Peake, Gormenghast 604.

${ }^{120}$ Peake, Gormenghast 608-20.

${ }^{121}$ Batchelor 131.
} 
The Black House has coloured lights projected onto it and strange music is played. Owls and cats, a throne and a crown remind Titus of Gormenghast. The crowd insists he is at his ancestral home. Something that may be an actor or an automaton appears, representing his mother, then another, representing his dead sister Fuchsia. These things insist Titus is dead, while Cheeta and the chorus encourage Titus to join the play. The dramatic conflict being enacted is typical of the Sabbat in that it revolves around whether Titus will be able to resist joining the performance. A circle is formed and Titus is expected to enter; but, just as he fails and shifts into it, his friend, Muzzlehatch interrupts, a figure who holds the powerful agency of a de Richlieu.

The rite holds many of the familiar elements of the black mass, and was readily legible as such to Batchelor. Titus is both the voyeur and the figure at risk of having his subjectivity overwhelmed and becoming involved in the performance. The rituals of Gormenghast are depicted as banal, and while they occasionally hold a spectacular element, in general they are not affective, and are ineffectual. Cheeta's performance, however, is affecting, if not for the reader then for Titus, and its bizarre psychodrama, where Titus is confronted not with sex, violence, and the trappings of the occult, but instead with his family, has the potential to 'derange once and for all the boy's bewildered mind', forcing him into 'the last throes of subjugation., 122 Where the participants in the Wiltshire Sabbat, or even the Holihaven dance, are able to continue with their lives after the ritual, the performance at the Black House is intended to be catastrophic for Titus.

The subjunctive world created by Cheeta's performance is a distorted version of the world of Titus Groan and Gormenghast that both Titus and the reader have abandoned. It performs the Freudian uncanny in a way that the other Sabbat performances do not, presenting Titus with the past he has abandoned if not repressed. Yet while the performance fulfils the technical requirement of the uncanny in that the repressed violently returns, readers are unlikely to be struck with the proof of the uncanny, its startling affect. Likewise, Titus is distressed, but Cheeta's other guests

\footnotetext{
${ }^{122}$ Peake, Titus Alone 929, 935.
} 
wonder whether the performance is for their 'delectation', ${ }^{123}$ casting themselves as voyeurs as much as Sabbat participants.

The performance at the Black House emphasises Titus' subjectivity rather than the action of the gathered participants. The black mass tends not to have a defined outcome, in part because the ceremony is so seldom concluded before it is interrupted, but also because it is hard to quantify the outcome of any ritual. However, Cheeta's performance is staged with the specific aim of humiliating Titus. The rite is intended to wound rather than celebrate; 'It mattered not how brilliant the spectacle, all, all would be lost unless the boy, Titus, suffered the supreme degradation. ${ }^{124}$ It threatens the integrity of a single subject rather than exercising the desires of the community that performs it.

Cheeta's revenge, unfathomable as it might be in design, at least offers a danger consistent with Titus' struggle. The pair has reached an impasse in their relationship because Titus, although he lusts for Cheeta, cannot commit to her because he finds her too domineering. There is a sense that the reader ought to approve of Titus' desire to remain independent in spirit (although in actuality he has been entirely dependent on Muzzlehatch and Juno in this new world). The black mass enacts the threat Cheeta presents to Titus, the undermining of his agency.

Where Wheatley, Howatch and Aickman's Sabbats strongly emphasise their insincere, ritualistic elements, Cheeta's performance foregrounds sincerity. The other Sabbats, with the exception of Amis', hold significance for their participants. Wheatley's Satanists understand what they are doing, as do the dancers of Holihaven; their actions 'make sense'. At the Black House, the performance is really relevant only to Titus, and perhaps Cheeta, at least to the extent that she is able to humiliate her quarry. Indeed, key participants, who play the roles of Titus' mother, Lady Groan, and his sister, Fuchsia, may have been replaced by elaborate automata, 'ill-tempered monstrosities'. ${ }^{125}$ Whether these things are poorly crafted machines, or simply actors portraying grotesque, angry characters is unclear. Lady Groan's face is 'a slab of marble over which false locks of carrot-coloured hair cascaded... there was little to be

\footnotetext{
${ }^{123}$ Peake, Titus Alone 919.

${ }^{124}$ Peake, Titus Alone 916.

${ }^{125}$ Peake, Titus Alone 931.
} 
seen by way of a mouth. ${ }^{126}$ This could be a mask or the face of a mannequin. Regardless, the involvement of others in Cheeta's performance is incidental and largely irrelevant, for the only participant who matters is Titus.

Generally, the mass is a threat because it can overwhelm individual subjectivity through immersive involvement in a group action. Titus Alone is aptly named, featuring an increased focus on Titus' subjectivity. Self-determination and independence, especially from the rules and rituals of the castle, are what Titus has been striving for throughout the Trilogy's narrative. In Titus Alone, Titus has become utterly self-obsessed, entirely, sincerely invested in himself, and the performance at the Black House assaults not propriety so much as the individuality and mien appropriate to a hero. This particular performance of the black mass distinguishes itself by seriously engaging with an individual, rather than offering a stage on which to enact a more generically Gothic performance.

The other black mass in the Trilogy appears in Boy in Darkness and, unlike the travesty at the Black House, involves both a diabolic figure and the suggestion of spiritual darkness. Peake seems to have been shy of locating Boy in Darkness definitely within the Trilogy's narrative. Gormenghast is named simply 'the Castle', and, curiously, some editions have substituted the epithet 'the Boy' for the name Titus, ${ }^{127}$ the edition I have worked from only has only a single use of the name. This creates a slight disjunction, in that the novella, while belonging to the world of Gormenghast, refuses to acknowledge this belongingness.

In Boy in Darkness, Titus escapes from the castle on one of his birthdays and explores a wasteland not mentioned in the main body of the Trilogy. There he encounters Mr Goat, half beast and half man, and his associate, Mr Hyena. The pair kidnaps Titus and takes him to their master, the Lamb, who dwells in a hellish subterranean place. The Lamb threatens to turn Titus into a creature like his minions. Titus is able to best the Lamb, slaying him with his own sword, after the beast has tried to transform him, but has failed due to some special quality of the boy. Mr Goat and Mr Hyena are transmuted back into gentler men, and Titus returns to Gormenghast. While there is no reference to the events of this narrative in the main

\footnotetext{
${ }^{126}$ Peake, Titus Alone 932.

${ }^{127}$ Winnington 212.
} 
body of the Trilogy, there is a slight connection in that the first two chapters of Titus Alone close with unexplained 'hyena laughter' resounding. ${ }^{128}$

Once Titus has been given to him, the Lamb issues instructions:

'Prepare a feast. Forget nothing. My crown; the golden cutlery.

The poison bottles; and the fumes; the wreaths of ivy and the bloody joints; the chains; the bowl of nettles; the spices; the baskets of fresh grass; the skulls and spines; the ribs and shoulderblades. Forget nothing or, by the blindness of my sockets, I will have your hearts out..., 129

The requirements for the ritual are in line with the precise lists of occult trappings for the black mass described by Wheatley and Howatch. Exactly how these things are to be used remains unclear, but the ritual will feature both fumes and feasting.

There is a macabre audacity in the Lamb's demands for the work of the butcher, bloody joints and bones, and his threat to have the hearts of his minions; in terms of the animal world of Mr Goat, Mr Hyena and the Lamb, this is as ghastly as Wheatley's requirement of infanticide. Yet, as in the case of Sepulchrave's death by owls, the Lamb's rite does not create an entirely separate subjunctive world apart from the body of the narrative. If the subjunctive world created by the black mass rejects a set of values and parodies a particular ritual, in the Lamb's underworld, it is no longer possible to discern what those values and that ritual might be.

The Lamb is closer to the Goat of Mendes than a symbol of Christ. The provocative juxtaposition of the imagery of the Son and the devil demands interpretation, but, in line with the non-discursive tendency of the black mass, it is difficult to usefully do so. The most obvious reading, that the Lamb is simply an attack on the image of Christ, perhaps as part of a more general critique of the church, is too broad to be useful, and there is little evidence in other parts of the Boy in Darkness or the Trilogy to support a reading along these lines. Even Winnington, who generally maintains enthusiasm even for Peake's most idiosyncratic moments, notes

\footnotetext{
${ }^{128}$ Peake, Titus Alone 759, 760.

${ }^{129}$ Mervyn Peake, Boy in Darkness (1956; London: Hodder Children's Books, 1996) 96.
} 
that the text is 'somewhat obscure to the reader's rational mind: the private symbolism and inconclusive biblical allusions are distracting rather than enlightening. ${ }^{130}$ The blasphemous frisson provided by the conflation of Christ with beast is more important than whatever it exactly means. The Lamb presides over the black mass, a rite that in place of meaning produces atmosphere. The master of the ritual, it is surrounded by an 'aura like death, gelid and ghastly - yet febrile also and terrible in its vitality', ${ }^{131}$ the aura of Sabbat revelry itself. Rather than the simple darkness associated with Wheatley's Goat, the Lamb is cold and hot, alive and dead.

As in Titus Alone, the black mass of Boy in Darkness has a quantifiable aim: 'Our lord will bestialize him', ${ }^{132}$ Hyena excitedly declares, anticipating Titus' actual transformation into a half-man, half-beast, like the creatures that have kidnapped him. Titus' arm begins to physically change in the Lamb's presence; the transformation will be both physical and psychic. This threat is similar to the dehumanising attack on Titus' individuality attempted at the Black House.

The Lamb's ritual has a literal effect that exceeds the metaphoric bestialization featured in Wheatley. It no longer creates a subjunctive world for its participants, but instead offers something real. In contrast, the endless rituals of Gormenghast are ineffectual, other than as a reiteration of the order that governs the castle. The subjunctive world they create is so closely aligned with the castle as to be indistinguishable; the power of ritual is lost. The rituals of Gormenghast are exhausted, but the black masses, the rituals that exist outside that edifice are not, carrying the potential to create permanent transformations that exceed the merely subjunctive.

The Trilogy creates subjunctive worlds in a significantly different way to the rest of the field discussed here. In Titus Groan and Gormenghast, the world of the castle itself is a subjunctive, secondary world, recalling something of the melancholy moods of the eighteenth century castle Gothic. This anachronistic subjunctive is distinct from the lurid Sabbat revels typical of other contemporary Gothics. The reader, like the Sabbat voyeur, witnesses the creation of a Gothic subjunctive; the

\footnotetext{
${ }^{130}$ Winnington 212.

${ }^{131}$ Peake, Boy in Darkness 94.

${ }^{132}$ Peake, Boy in Darkness 103.
} 
world of the castle becomes the stage on which the Gothic is performed, rather than the limited and very concentrated eruption of the Sabbat common in other texts.

Gothic narrative functions by leading readers processionally through the text's staging of the Gothic, typically towards 'the worst', whatever that might be. Castle Gormenghast itself has provided the route of this procession, even if ultimately the narrative does not proceed to any particular horror. The Trilogy complicates readers' relationships with its Gothic subjunctive by turning away from the world of the castle in Titus Alone and Boy in Darkness, offering a narrative that, rather than continuing to move further into the celebration of the Gothic, instead seems to distance itself, frustrating the reader's interest in Gormenghast.

Peake approaches the Gothic differently in Titus Alone and Boy in Darkness. The new world of Titus Alone is tonally discontinuous with the earlier two books, and indeed with the other Gothics treated in this chapter. Boy in Darkness, an adjunct to the Trilogy, also distances itself from the castle. However, both of these texts turn to the Sabbat, so typical of the contemporary Gothic field, to provide a way of staging the Gothic. This represents a shift in strategy, albeit a slightly awkward one, from a nostalgic to a more contemporary modulation of the Gothic.

\section{Conclusion: The Highgate Vampire}

The black mass and the Sabbat were not confined to the written Gothic, appearing in films of the period too: The Kiss of the Vampire (1963), The Witches (1966), Satan's Skin, aka Blood on Satan's Claw (1970), The Wicker Man (1973), and The Satanic Rites of Dracula (1974) all feature celebrations of the Sabbat, as, of course do the filmed adaptations of Wheatley's novels, The Devil Rides Out (1967) and To the Devil a Daughter (1975). In fact, the black mass was not confined to fiction at all.

Highgate Cemetery was troubled by a vampire in the late nineteen-sixties and early nineteen-seventies, necessitating an extensive vampire hunt. Occult investigators, including members of the British Occult Society, flocked to the site, and reported that the graveyard had been desecrated. Tombs were broken open and evidence of sinister ritual practices was discovered. Monuments had been daubed with occult symbols, and bodies found burnt and beheaded. Obviously the vampire was in cahoots with organised groups of Satanists. On Friday, March 13, 1970, in the wake 
of an ITV broadcast publicising the phenomena reported at Highgate, a mob of would-be vampire hunters descended on the cemetery. Around a hundred of them broke into the grounds so as to search for the monster, and had to be driven out by the police with searchlights. ${ }^{133}$ The Society continued its investigations, although by 1974, its President, Robert Farrant, would be standing trial in relation to his group's activities in the cemetery after a disinterred and headless body was found in a nearby parked car. Although this particular act was not Farrant's doing, it drew attention to what was occurring amongst the graves. Farrant maintained the rituals his society performed were attempts to exorcise the influence of evil from Highgate. The Times, unconvinced, covered the trial with headlines such as 'Stakes driven into corpses in cemetery', which is what we might expect in the course of a vampire hunt, and 'Court told of naked girl dancing among coffins', which, if we reflect on it, is not. ${ }^{134}$

Why was it necessary for a young woman to disrobe and dance inside the tombs? Why was it necessary to take photographs of her? We might understand that Martine de Sacy, the naked dancer amongst the coffins, as going 'skyclad' as part of Wiccan ritual practice, but this seems less likely when we note de Sacy, at least according to the News of the World, claimed to have participated in ritualised group sex. ${ }^{135}$ The vampire hunt, it seems, began to shade into the Sabbat. The actions of Farrant and others, who were avowedly fighting the evil in the cemetery, must have seemed so close to satanic ritual, at least in the minds of the 'ordinary people' evoked in Judge Argyle's sentencing, as to have been indistinguishable.

The participants in the hunts were doing something more than stalking a vampire; they were attempting to enact the Gothic by recreating a bundle of narratives, themes and sensory experiences. The black mass and the vampire were notions both sufficiently central to Gothic practice as to be treated together, and to shift together into the real from the generally fictional world of the Gothic.

\footnotetext{
${ }^{133}$ For an account of the affair, see Bill Ellis, "The Highgate Cemetery Vampire Hunt: The AngloAmerican Connection in Satanic Cult Lore," Folklore 104.1/2 (1993).

134 "Court Told of Naked Girl Dancing among Coffins," The Times June 12 1974: 5; "'Stakes Driven into Corpses in Cemetery'," The Times June 13 1974: 4.

${ }^{135}$ Ellis, Raising the Devil 232.
} 
If the Society believed a vampire was haunting the cemetery, then its methods seem curiously inexpert. Hunting it at night, when it is commonly understood that that is when the undead are most powerful, seems foolhardy. This might not have been an astute vampire-hunting practice, but it does help create the appropriate atmosphere in which to enact the Gothic. Faced with the vampire's absence, it became necessary for the players to perform it.

The hunt was a particular kind of play, a celebration of vampire hunting rather than a real effort to kill a monster. A similar point emerges when we consider their methodology. Ritual exorcism has never been the favoured method for disposing of a vampire, yet this is what the Society claimed it was attempting. However, this does have the distinct advantage that it allowed the exorcists to confront the vampire as a spirit; they did not actually have to see it, only to somehow 'sense' it. Thus, by reconfiguring the way in which they might 'perceive' a vampire, the hunters were able to enact the direct conflict with the undead that features in Gothic narrative. It also enacts the ritualism typical of contemporary Gothic practice. The absence of an actual monster in a narrative structured around that figure must have been a frustration, but the fearless vampire hunters muddled through as best they could, recreating the erotics of the Gothic, marrying cemetery atmosphere with salacious sexual elements and weird ritualism, even if the rationale for their narrative became unclear. The Highgate vampire, and the Sabbat-like dances employed to bring about its dispatch, suggest that the act and experience of performing the Gothic itself is more important than its meaningfulness or the coherence of its narrative. The Gothic is characterised by the experience offered in its ritualised action, more than its ability to generate meaningful discourse.

The Highgate vampire demonstrates the way in which Gothic habitus can occasionally exceed text, existing as a subjunctive space produced within the real. When we perform the Gothic by reading a book, this is a sanctioned practice. Farrant and his followers were punished because they enacted practices informed by Gothic habitus in an inappropriate context.

Wheatley's Sabbat, reiterated throughout his popular series of black magic stories, occupied a central place in British Gothic practice throughout the sixties, as demonstrated by its replication and modification in the texts discussed in this chapter. Similar tropes, narratives and themes are repeated again and again in most Gothics. In 
the texts explored here, the black Sabbat brings these elements together into a procedure, where readers and characters are led processionally towards the Sabbat's knot of playful horrors and pleasures. Each text modulates this performance in a distinct way, identifying its own place within the wider practice, which offers a contiguous set of reading experiences. Beyond being a simple trope, the black mass became a textual practice, encouraging and becoming emblematic of a style of reading that was involved, rapid and generally unreflective, likely to bring about the absorbed reading state Nell describes - a metaphorical revel. The constant feature of the voyeur provides an analogue for the reader. The risk for those who spy on the dark rite is that they will become caught up in it. This is the risk we pretend is present in the Gothic; that its terrible scenes will overwhelm us, harm us, as if we cannot close our eyes or put the book down. Admitting that we can stop the game is to withdraw our commitment to it, although more often than not, the Sabbat is stopped before it exceeds our ability to engage with it. The Sabbat's interruption is a promise as much as a frustration, in that we know worse was to come, although we did not encounter it.

Howatch draws heavily on Wheatley's version of the Sabbat, confirming its persistence by recapitulating it, but she also gently modifies the black celebration. Where the Wiltshire Sabbat is a generalised festivity that includes an initiatory function, the Sabbat at Colwyn Court is a perversion of the marriage ceremony. The Devil on Lammas Night emphasises the reading of the Sabbat as a free-love gathering that became available through the zeitgeist of the swinging decade. Contrarily, it also attempts to maintain the kind of sexual decorum necessary in paperback romance. While the Sabbat became a central part of Gothic practice, individual iterations of the rite provided tonally distinct reading experiences. The meaning of the Sabbat is approximate compared to the consistency of experience it offers.

Amis' use of the elements of the Sabbat in The Green Man suggests the rite need not be performed literally or in its entirety to retain the practical sense that characterises the rite. Amis' use of the Sabbat emphasises its value as an entertainment as much as a transgression. It also suggests that regardless of the degree of valorisation his work received as 'literature', to perform the Gothic, it was still expedient to embrace the Sabbat as it had been configured in popular practice. Maurice identifies the performance playing out before him as a sham, an inauthentic staging of exotic desire, but where de Richlieu and Rex are credulous, Maurice is a resisting reader until the illusions actually attack him. Wheatley stages the Gothic 
concurrently with the thriller, and Howatch does the same with the paperback romance; The Green Man provides a reading experience that, from time to time, resists the Gothic as it orchestrates its simultaneous involvement in several genres, including comedy, satire, philosophical science fiction and the literary novel.

Aickman's tales are more focussed performances of the Gothic than Amis' polygenous novel. They complicate Gothic practice by seeming to load their performances with meaning that ought to be deciphered and reflected upon, encouraging specifically literary reading practice. Yet this meaning is a will-o'-thewisp, a misleading glimmer without substance; the texts are not strongly discursive. The suggestion of meaning stays with their readers, an echo of the Gothic performance, just as the consequences of the Northamptonshire Sabbat and the Holihaven dance remain with his characters.

Where the other texts discussed in this chapter are strongly engaged in contemporary Gothic practice, Peake's Trilogy, while an iconic text in the genre, performs the Gothic quite differently, and is something of an outlier in the field. It is difficult to make general claims for the Trilogy, as Titus Alone and Boy in Darkness differ substantially from the first two books. Nevertheless, they feature the only iterations of the Sabbat that are not salacious sexual burlesques. Where the other full Sabbat performances tend to the ritualistic, emphasising a communal celebration of something ghastly, Peake's Sabbats tend to sincerity, placing Titus himself at the centre of the ritual as its object.

Peake's black masses tend towards the sincere. The subjunctive they create does not exceed the world that the Trilogy has already established. While the Trilogy presents the Sabbat, its function is different, and Peake offers a different reading experience, less immediate than the typical Gothic of the day, retaining a disengaged, dreamlike quality. Considered within the context of the field in which it found its popular readership, The Gormenghast Trilogy breaks with Gothic practice in substantial ways.

This returns us to Highgate. The vampire reminds us that the Gothic has a relationship with the historical real, but that it is rather more specific than Gothic criticism might suggest. It seems some way from Punter's claim, for instance, that the Gothic of the period explores 'the failure of accounts of the world... predicated on the 
supremacy of subjectivity. ${ }^{, 136}$ The vampire itself suggests the astonishing ability of the human mind to triumph over the merely real, to create a subjunctive world even without the aid of text or film. The goings-on at Highgate resist depth-based readings that might discover a cause in a particular historical anxiousness, relating to subjectivity or other appealingly discursive topics. The Highgate vampire is inescapably silly, but first and foremost, the Highgate vampire is 'about' the Highgate vampire and cannot principally be understood as an allegory. In this, it reflects the insincerity of Gothic performance.

The vampire can be understood as an ongoing, partly imaginary, partly enacted event that demonstrates how the Gothic, while usually performed through engagements with text, is performed in the real too. That this performance involved something approximating the black mass suggests just how central the rite was to the genre at the time. While a handful of people were involved in transgressive behaviours at the cemetery, for many more, especially for the teens that began invading the graveyard on Halloween, the site provided an opportunity to indulge in an affective, imaginative Gothic experience, without having to go to the lengths that the crypt-breakers did. The most transgressive activity at Highgate was doubtless the work of a handful of disturbed or misguided people, but for them and the many other visitors to the cemetery, the night time journeys were closer to an established cultural practice. We might not immediately understand what makes someone interfere with interred bodies, but the little thrill of going for a walk, perhaps with others, somewhere spooky - an overgrown and vampire-haunted graveyard, perhaps - is easier to see. This is what drew Clarinda Hartley out into the night. Visitors to Highgate motivated by a voyeuristic desire to 'see' the monster instead became participants in the performance of the vampire.

As Erika Fischer-Lichte notes, ritual is not just done, it is re-done and predone. ${ }^{137}$ The texts treated in this chapter repeat content, but more importantly, they loosely repeat experience, and it is this repetition that allows readers to identify them as Gothic. As much as this is a ritual, it is also a type of play, an entertainment.

\footnotetext{
${ }^{136}$ Punter, Literature of Terror 143.

${ }^{137}$ Erika Fischer-Lichte, Theatre, Sacrifice, Ritual: Exploring Forms of Political Theatre (London: Routledge, 2005) 41.
} 
Schechner argues in the context of the theatre that it is a mistake to separate supposedly frivolous entertainment from 'serious' ritual practice. ${ }^{138}$ Huizinga suggests something similar when he claims 'Frivolity and ecstasy are the twin poles between which play moves. ${ }^{139}$ Frivolity is characteristic of play, while ecstasy, a state beyond oneself, is the characteristic of participation in certain rituals, and would certainly include the Sabbat. The rite forms a culmination of Gothic action. Those who witness it more often than not end up in its midst, stalling it or participating in it. While the Sabbat does not hold strongly discursive meaning, this chapter argues that its frequent depiction of voyeurism, or interested readers, together with its presentation of the most grotesque, macabre and sexualised moments these texts offer, provides a venue in which the Gothic text frames and examines itself.

${ }^{138}$ Schechner $155,158-60$.

${ }^{139}$ Huizinga, 21. 


\section{Chapter Four:}

\section{Towards a New Zealand Gothic: Practice in An Underdeveloped Field}

William Broughton celebrated John Hooker's 1971 novel, Jacob's Season in a 2001 number of Landfall, claiming the nearly-forgotten novel ought to be canonical, and praising its articulation of a 'semi-mythical and Gothic South Island'. ${ }^{1}$ The novel is a despairing kind of comedy; Jacob Small, drunkard, philanderer and compulsive liar, leaves or is left by his wife. Nothing especially sinister occurs; there is no violence, no supernaturalism, and the grotesque depiction of the characters is basically goodnatured. In substance, the novel is not really a Gothic, although it certainly does take the occasional Gothic turn. Nevertheless, Broughton believes that

\footnotetext{
Hooker-country is Gothic to its core - a place of crumbling stone, knitted woollens and dead leaves; a ghost-town. He nails the dampness, both spiritual and actual, of a city in which nineteenth century mercantile ambition has given way to echoes and winter mists. $^{2}$
}

The Landfall piece is interesting for two reasons. It suggests that by the turn of the millennium, there was a growing interest in identifying a New Zealand Gothic; indeed, the review appears immediately after a brief discussion of local horror films. ${ }^{3}$ Secondly, Broughton's review describes the New Zealand Gothic as an atmosphere rather than as dependant on the procedures of haunting, menace, and monstrousness that define other national Gothics. Knitted woollens take the place of devouring shadows. More familiarly, the Gothic is linked to the real, and captures the city of Dunedin, or, as it is thinly disguised in the novel, 'Flagstaff'.

\footnotetext{
${ }^{1}$ William Broughton, "Dusted Off: John Hooker's Dunedin Gothic," Landfall 201 (2001): 188.

${ }^{2}$ Broughton, "Dusted Off" 189.

${ }^{3}$ Philip Matthews, "Local Infections: New Zealand Horror," Landfall 201 (2001): 183-7.
} 
While Broughton labels it a 'Dunedin Gothic', Jacob's Season is actually at its least representational when it is at its most Gothic. Jacob stands in a cemetery and observes

Black rain, hard rain, it doth fall, sweeping from dark satanic hills, secret gloomy mountains and mysterious, high, tussocky places, where the blinded sheep is silent and the red deer has gone, long gone. The hard rain falls on growing trees and ruined chimney pots, on black slate roofs, on dodding bald heads, on cacti in rubber tyres, on cold jersey cows, knee-deep in rank, raw grass, on grinning gargoyles and country graveyards where headstones slump and stagger and fennel droops in earth of humus and fallen leaves by cypresses of dark. Where are the tiny flowers and tender shoots? Where is the seal and the giant albatross?... Falls the rain, it falls on forgotten Jewish graveyards (Moses Louis Lazarus is risen from the dead), on Ionic crosses and blundering gasometers shooting sparks and breathing in the dark. In the rain, black Victorian angels fall with broken wings and lie in hidden places...

The snow is stained with blood from underground drains, and labyrinthine sewers, dead leaves and birds' bones, drowned field mice and dead forest creatures, insects, gravel, chimney soot, coal dust and smoke sweeping over this country city. Now the clouds have gathered from battered peaks, the dark, windswept vapour blinding across Mount Flagstaff, Saddle Hill and Mount Cargill to settle on mossy roof tops, factory chimneys, the soaring shot tower, turreted embattlements and cracking crenellations.

Sheer walls of stone, the Gothic chimneys rise from patterned roofs of Spanish tiles. Jacob stands and shivers. ${ }^{4}$

In typical Gothic fashion, Jacob's inner turmoil leaks into the outer world. Perhaps the most remarkable thing about the passage is the sheer energy with which it smothers

\footnotetext{
${ }^{4}$ John Hooker, Jacob's Season (London: Barrie \& Jenkins, 1971) 143-4.
} 
the southern landscape under a vast array of Gothic trimmings. Hooker's prose tends to the compression and playfulness of poetry, and these qualities come to the fore in passages like this, where the language becomes explicitly rhythmic and repetitive. The narrative voice meshes with Jacob's, and a Gothic milieu is built, piece by piece, in a heightened, consciously literary mode.

Physical landmarks are shifted into an imaginative, literary, Gothic space. Broughton uses the label 'Dunedin Gothic' to emphasise the connection between Hooker's text and the city, but this is a place which simply does not exist in New Zealand; indeed it is the sort of place that exists more strongly in text than it does in the real. While it is only a light disguise, we should remember that Dunedin has been renamed Flagstaff, creating a distance between the place and its representation. If this is Dunedin Gothic, then why is it not set in a place named Dunedin?

The Gothic space described here contains no tiny flowers or tender shoots, leaves and birds and mice and forest creatures are dead, underground drains bleed. Yet as much as it is a deathly place, it is full of unexpected, sinister life too. Gravestones slump and stagger. Strange life may come forth from the graves themselves; 'Moses Louis Lazarus is risen from the dead'. Gasometers breathe and spark in the dark, while 'black Victorian angels fall with broken wings and lie in hidden places'. Strangely, the angels fall with wings already broken, rather than having their wings shatter on impact with the ground. The careful ordering of the sentence suggests that the angels fall because their wings have broken rather than because of any structural flaw, which in turn suggests they have been supported by their wings. Although we see them at their moment of collapse, they once had motion, even life. Even stranger, there are angels, plural, falling. Rather than simply seeing statuary coming down, we see the fall of the rebel angels replicated; something monumental in both senses of the word. Flagstaff might be a wasteland, but it is inlaid with mythic import.

The density of the imagery coupled with the velocity of the prose means we tend not to explore the specificity of the images but to experience them at a surface level. The banal (cacti, slate roofs) is mingled with the significant (fallen angels, resurrected men); the natural (seals, albatrosses) sits next to the weird (black rain, bloody snow). Readers cannot stop to unpick each of these images in turn, but a Gothic, carnivalesque texture emerges in these arrangements. 
The same can be said of the manic intertextuality in the passage. As we read it, we barely have time to make sense of one allusion before we are confronted with another. Rain that 'doth fall' may recall a prayer for times of 'Dearth and Famine' from The Book of Common Prayer, which beseeches God to make the earth bountiful, although the suppliant acknowledges the justness of his suffering. ${ }^{5}$ At the same time the 'hard rain' probably suggests the Bob Dylan song, 'A Hard Rain's A-Gonna Fall', where the singer finds himself in an apocalyptic landscape, and, not unlike Jacob Small, recounts being amongst 'misty mountains' and in 'the mouth of a graveyard' ${ }^{6}$ The 'Black rain' here describes the fall of soot from the air but again probably suggests a more fully catastrophic landscape; a black rain was reported after the detonation of the nuclear bomb at Hiroshima.

The punning 'dark satanic hills' rearranges Blake's 'And did those feet in ancient time'. ${ }^{7}$ Blake's England is marred by the industry of 'Satanic Mills', although in the poem he hopes to recover it. In contrast, Jacob's Flagstaff is hardly a potentially green or pleasant land. Even without the fall of factory soot, the hills themselves are oppressive, invested with diabolic presence. The pun suggests that in Jacob's Season the problem is not that humanity has created dark forces but that the New Zealand landscape itself is satanic.

The construction 'Falls the rain' is deliberate, recalling Edith Sitwell's 'Still Falls the Rain'. Again the reference is to a near-apocalyptic poem, and Hooker's use of the rain as a uniting element, bringing together Jacob, jersey cows, and the dodding heads of others, seems to be drawn from Sitwell. She describes 'Dives and Lazarus: / Under the Rain the sore and the gold are as one. ${ }^{8}$ Sitwell's poem also features beaten

\footnotetext{
${ }^{5}$ Church of England, "In the Time of Dearth and Famine," The Book of Common Prayer, and Administration of the Sacraments and Other Rites and Ceremonies of the Church of England (Birmingham: J. Thompson, 1791).

${ }^{6}$ Bob Dylan, " A Hard Rain's A-Gonna Fall," Bob Dylan: Lyrics 1962-2004 (New York: Simon \& Schuster, 2004) 59.

${ }^{7}$ William Blake, "And did those feet in ancient time," William Blake: A Selection of Poems and

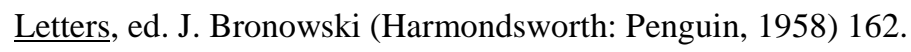

${ }^{8}$ Edith Sitwell, "Still Falls the Rain," Collected Poems (London: Macmillan, 1958). 272-3.
} 
and hunted animals; in this passage from Jacob's Season, all the animals are cold or dead, asleep or absent.

The texts Hooker evokes are serious, religious or apocalyptic. Yet here, they become part of a grotesque exhibition, their meanings and affective power glimpsed and then gone, compressed to the point of comedy. Hooker's Gothic turn tends to pastiche; it is self-consciously literary, but is interested in the suggestive power of the texts it invokes, their surfaces, rather than a serious engagement with them. It evokes a mood, but by pointing away from the text itself toward other texts, it distances readers from an immersive involvement in the moment.

Broughton praises the novel for its ability to depict 'humanity' and the 'local', ${ }^{9}$ and this is fair to a degree. However, when it is its most Gothic, as in this passage, Jacob's Season is not interested in people or place. It escapes what is merely Dunedin, into a space populated with fallen angels and the clouds of the end. It can hardly be a coincidence that for all its intertextual referentiality, not one of the references that Hooker makes is really local. For all the hard-raining energy of the Gothic here, it is an obviously imported practice. Is there such a thing as a New Zealand Gothic? Are there regional variations?

Broughton frames the novel as a Dunedin Gothic, but if the Gothic is based in habitus, then it cannot simply be declared. Most common readers would be unable to describe a Dunedin Gothic, or indicate texts that appear to naturally belong within that category. Chapters two and three discussed specific moments in Gothic practice in the United States and England, and argued for the historic specificity of the genre, suggesting we ought to read these texts within the context of the fields from which they emerged. The New Zealand Gothic has yet to achieve a field of the scale and coherency that these other national Gothics have; it has not yet constructed a selfevident canon of texts that it can use to define itself. Curiously, it is quite unlike the Australian Gothic, which 'has been a consistent presence in Australia since European settlement. ${ }^{10}$ The New Zealand Gothic is a more diffuse phenomenon. It remains linked to a historical habitus, but the field it has generated is far weaker. There is a

\footnotetext{
${ }^{9}$ Broughton, "Dusted Off" 190.

${ }^{10}$ Gerry Turcotte, "Australian Gothic," The Handbook to Gothic Literature, ed. Marie Mulvey-Roberts (New York: New York UP, 1998) 10.
} 
New Zealand Gothic, but it has not been articulated well by the extant criticism, which does not engage with the tenuous status the genre has in this particular milieu.

Discourse surrounding New Zealand writing has only recently been interested in labelling literary productions as Gothic. Rather than illustrating a moment within a field, as chapters two and three have done, this chapter is slightly more speculative, reflecting the nascency and diffusion of the New Zealand Gothic. It briefly surveys critical work relating to the genre, and suggests the New Zealand Gothic has an awkward relationship with New Zealand literature in general. However, it argues the Gothic is an important component in works by Frank Sargeson and Janet Frame, both writers central to the New Zealand literary canon, and that this has been underrecognised. If there is a desire to develop the New Zealand Gothic, then these two writers are a useful place to begin.

\section{Some Problems in Critical Versions of New Zealand Literature and the New Zealand Gothic}

National Gothics are one of the most basic ways in which Gothic studies is organised, and there is a growing trend that suggests each nation will have its own Gothic. While this thesis has preferred to explore smaller fields, these have still been within wider, loosely national traditions. However, while there has been a substantial scholarly effort put into explicating the Gothic texts and tropes associated with the United Kingdom, North America, and Europe, the study of New Zealand's Gothic is still at an early stage. There is no monograph on the subject, although it is dealt with in chapters in more general considerations of New Zealand literature. ${ }^{11}$ There is one collection of essays, recently published, that specifically addresses the New Zealand Gothic. ${ }^{12}$ Beyond this, there are only a handful of journal articles. Nor has there been

\footnotetext{
${ }^{11}$ Mark Williams, Leaving the Highway: Six Contemporary New Zealand Novelists (Auckland: U of Auckland P, 1990); William J. Schafer, Mapping the Godzone: A Primer on New Zealand Literature and Culture (Honolulu: U of Hawai'i P, 1998).

${ }^{12}$ Misha Kavka, Jennifer Lawn and Mary Paul, eds., Gothic NZ: The Darker Side of Kiwi Culture (Dunedin: Otago UP, 2006).
} 
anything like an anthology of New Zealand Gothic fictions that might describe a Gothic canon in a New Zealand context.

These points are symptomatic of a wider difficulty. Where other subcategories of the Gothic (English Gothic, female Gothic and so forth) suggest more-or-less selfevident groups of texts, no such grouping presents itself when we talk of a New Zealand Gothic. The American Gothic immediately brings to mind Brockden-Brown, Poe, Hawthorne, and later, Bradbury and King. Certainly, various claims are made for where we might find the New Zealand Gothic, but this is not the same thing as a consensus grouping that does not need to be negotiated, a Gothic canon. This uncertainty has in turn led to the perception in some quarters that, in New Zealand, there is 'almost no gothic. ${ }^{13}$ On the face of it, this is a peculiar situation; in both popular and scholarly examinations of the national psyche, critics often depict New Zealand art as moody, anxious or despairing, claims that might suggest that it is involved in the Gothic to some degree. ${ }^{14}$

Mark Williams discussed Janet Frame's suburban Gothic as early as 1990, ${ }^{15}$ but the first substantial treatment of a national Gothic appeared in the American critic William J. Schafer's Mapping the Godzone in 1998. Schafer understands the Gothic as a measure of cultural development; 'If you feel raw, young, unformed, lacking in historical status, a way to gain stature is to acquire suitably ancient ghosts. ${ }^{16}$ Thus, by acquiring ghost stories, Schafer argues a nation might in fact develop its sense of 'athomeness'. ${ }^{17}$

\footnotetext{
${ }^{13}$ Lydia Wevers, "The Politics of Culture," Writing at the Edge of the Universe: Essays from the 'Creative Writing in New Zealand' Conference, University of Canterbury, August 2003, ed. Mark Williams (Christchurch: Canterbury UP, 2004) 116.

${ }^{14}$ Rose Hoare, "Art of Darkness," Sunday Star-Times 12 November 2006. Jennifer Lawn, "Introduction: Warping the Familiar," Gothic NZ: The Darker Side of Kiwi Culture, eds. Misha Kavka, Jennifer Lawn and Mary Paul (Dunedin: Otago UP, 2006).

${ }^{15}$ Williams, Leaving the Highway 30-56.

${ }^{16}$ Schafer 138.

${ }^{17}$ Schafer 143.
} 
If the Gothic is a discrete practice, this practice might well be disrupted by the upheaval that is part and parcel of a colonial culture, but it is not necessarily useful to view the genre as a marker of cultural 'maturity'; cultures do not age like people do. However, Schafer's observation that the Gothic relates to a sense of at-homeness, is an interesting one; the Gothic requires not just ghosts, but the right sort of ghosts, spectres that are seamlessly integrated into the place they haunt, so as to converge with its history.

This is a potential problem for the New Zealand Gothic. In the absence of the trappings of established Gothic traditions - castles populated by fiendish aristocrats, swamps draped with Spanish moss and possessed by terrible spirits - there is a sense that, despite Broughton's claims for the Gothic quality of dead leaves and knitted woollens, New Zealand is uncertain how and where it ought to perform its own Gothic.

Problematic, too, is the way in which Schafer draws pakeha and Maori experiences together into an 'Aotearoa gothic':

A common cultural link between pakeha and Maori, although unconscious and largely unacknowledged, is the belief in the hauntedness of the landscape, the sense that Aotearoa New Zealand is a land of sinister and unseen forces, of imminent (and immanent) threat, of the undead or revenant spirits. ${ }^{18}$

This is an important connection to make, although perhaps not as simple as Schafer suggests. ${ }^{19}$ For Maori, ancestral spirits are integrated into a traditional lifeworld, part of tikanga Maori (Maori custom); for pakeha, a ghost is, at least in part, a scandal to reason. Given the unlikeness of these experiences, pakeha and Maori Gothics might, in fact, be separate practices. Indeed, the term 'Aotearoa gothic' is suggestive of this complexity, combining as it does an uneasily negotiated postcolonial compromise national identity with a pakeha cultural import which, in turn, draws part of the

\footnotetext{
${ }^{18}$ Schafer 137.

${ }^{19}$ Lawn also resists this easy conflation. Jenny Lawn, "Domesticating Settler Gothic in New Zealand Literature," New Literatures Review 38 (2002): 47-8.
} 
meaning of its name from an early modern European misrepresentation of a culturally Gothic past, complete with assumptions of savagery and barbarism. While Schafer might not signal exactly where this shared hauntedness manifests textually, at least his choices of New Zealand Gothic are comprehensible: Frame's 'The Lagoon', Ronald Hugh Morrieson's work, the early films of Peter Jackson. ${ }^{20}$

Further critical articulations of the New Zealand Gothic followed, often preferring to develop regional rather than national Gothics. David Craig describes a Taranaki Gothic, which, for him, is basically a plot form:

It's a story of provincial delusion and slapstick exhilaration getting itself caught up in things that turn out to be much bigger, shakier and more sinister than anyone had imagined... Innocence and exuberance running to trauma... ${ }^{21}$

This seems to adequately express the shape of some of Morrieson's work, but Craig's vision is in fact much wider, discerning the pattern in a variety of 'identity narrative experiences', including the Anzac invasion at Gallipoli, the career of New Zealandborn race horse Phar Lap, the Muldoon government's Think Big economic projects, and The Lord of the Rings films. ${ }^{22}$ Whatever Craig is suggesting the Taranaki Gothic is, it certainly exceeds the region from which it takes its name, and, indeed, any commonsense understanding of the Gothic.

Jennifer Lawn, like Broughton, suggests a Dunedin Gothic; her reading of the film Scarfies, set in Dunedin, links it to real, seeing the "“spirit" of capitalism' as haunting the film. ${ }^{23}$ She believes

\footnotetext{
${ }^{20}$ Schafer $137-8,148-51$.

${ }^{21}$ David Craig, "Taranaki Gothic and the Political Economy of New Zealand Narrative and Sensibility," New Zealand Sociology 20.2 (2005): 19.

${ }^{22}$ Craig, "Taranaki Gothic" 19-20.

${ }^{23}$ Jennifer Lawn, "Scarfies, Dunedin Gothic, and the Spirit of Capitalism," Journal of New Zealand Literature 22 (2004): 127.
} 
Gothic literature in New Zealand, like other forms of Pakeha cultural expression, performs the ideological work of transforming “colonization," denoting systematic and enforced territorial appropriation, into "settlement," with its implications of an organic assumption of what Linda Hardy has termed "natural occupancy." 24

In some ways, this is simply a postcolonial politicisation of Schafer's argument; however, perhaps the key phrase here is 'like other forms of Pakeha cultural expression'. Lawn does not regard the Gothic as a truly distinct mode, but instead as interchangeable with other forms, achieving the same 'work'. In this way, her argument is similar to the one Sam Neill makes in his documentary on New Zealand film, Cinema of Unease, where moody or paranoid but basically realist films are treated as more-or-less continuous with the zombie yuck-fest, Braindead. All are seen as expressing a national 'sense of the perilous'. ${ }^{25}$

Lawn, together with Misha Kavka and Mary Paul, also edited the collection, Gothic NZ: The Darker Side of Kiwi Culture. 'How would we begin to address the question "where is gothic here?" in (around, under) these South Pacific islands at the antipodes of Western Europe?' wonders Lawn in her introduction. ${ }^{26}$ Lawn acknowledges the diffuseness of the New Zealand Gothic; the collection features discussions of colonial architecture, tattooing, the Gothic potentialities of home renovation, the racist possibilities of The Lord of the Rings, and the cutesy-creepy aesthetic of Misery, an Auckland-based illustrator who has her own range of streetwear. ${ }^{27}$ Also included are considerations of glum modernist architecture, and the

\footnotetext{
${ }^{24}$ Lawn, "Domesticating Settler Gothic."

${ }^{25}$ Sam Neill, Cinema of Unease: A Personal Journey by Sam Neill, British Film Institute and Top Shelf Productions, 1995.

${ }^{26}$ Lawn, 'Warping the Familiar" 11.

${ }^{27}$ Lochhead; Mark Jackson and Christopher Braddock, "Incised Skin and Other Spurs"; Misha Kavka, "Out of the Kitchen Sink"; Sarah Shieff, "Well-Laundered Elves: Purity and Degeneration in The Lord of the Rings,"; Misha Kavka and Misery, "Misery: Art and Fashion"; all in Gothic NZ: The Darker Side of Kiwi Culture, eds. Misha Kavka, Jennifer Lawn and Mary Paul (Dunedin: Otago UP, 2006).
} 
incursion of tree roots into plumbing. ${ }^{28}$ Ian Wedde's afterword has the genre including both genetic engineering and tourism. ${ }^{29}$ Gothic $N Z$ prefers a version of the Gothic that is a little quieter and more seemly than the Gothic at its most vivid. Current criticism characterises the New Zealand Gothic as a feeling of quiet unease, a subtle darkening. In the main, it avoids canonical writers. It is easy enough to discover the Gothic in these disparate locations; but how are we to account for the disparateness of these manifestations, and what is it that connects them?

Lawn's answer is evasive: nothing is Gothic in itself, but it is possible to look at anything Gothically. ${ }^{30}$ This misses the point that sometimes it is more appropriate to read a text as Gothic, and sometimes it is less so, and unless there is something in a text that prompts a shift in reading strategy, the Gothic is reduced to a mode of interpretation, a hermeneutic manoeuvre.

Taken together, current discussions of the New Zealand Gothic highlight a handful of common discursive issues. There is a demonstrable desire to examine a New Zealand Gothic, but often, discussions focus on the only marginally Gothic. There is also a desire to historicise the New Zealand Gothic, although as yet, no genuinely compelling suggestion as to how this linking might operate has emerged. Interestingly, although Lawn is the only critic here who displays any awareness of international work in Gothic studies, efforts to explicate the New Zealand Gothic display one of the principal problems of the wider field; namely, it cannot reliably identify when a text is significantly Gothic, and consequently, cannot begin to articulate what the Gothic might be.

Part of the problem facing critics of the New Zealand Gothic is New Zealand literature itself. This thesis argues that the Gothic, even though it appears in textual form, represents a separate practice from the literary. Certainly, these two practices

\footnotetext{
${ }^{28}$ David Craig, "Gothic Inversions and Displacements: Ruins, Madness and Domesticated Modernism," Gothic NZ: The Darker Side of Kiwi Culture, eds. Misha Kavka, Jennifer Lawn and Mary Paul (Dunedin: Otago UP, 2006); Kavka, "Out of the Kitchen Sink," 61-2.

${ }^{29}$ Ian Wedde, "Afterword: How Gothic Is It?" Gothic NZ: The Darker Side of Kiwi Culture, eds. Misha Kavka, Jennifer Lawn and Mary Paul (Dunedin: Otago UP, 2006) 152-4, 159.

${ }^{30}$ Lawn, "Warping the Familiar" 11-5.
} 
sometimes converge in carefully orchestrated textual performances, seeming to blur into one another, but equally, they can exist independently. The corollary of this is that critical frames we use to explore New Zealand literature will not automatically help us understand the New Zealand Gothic.

New Zealand's national literature is one of the very last colonial literatures in English to emerge. It is only very recently, as evidenced in the publication of the excellent study of early writing, Maoriland, that scholarship has begun to rediscover the settler and postcolonial Maori literatures that were once present in New Zealand. ${ }^{31}$ This first period, however, has been obscured by the birth of what, even now, is generally understood as the national literature, a group of texts that form a cohesive field that really only began to emerge in the nineteen-thirties, at the time that, internationally, a more aggressive style of modernism was beginning to shade into realism. This version of New Zealand literature tends to locate Katherine Mansfield as the first New Zealand writer of note, and from there looks to the output of writers like Frank Sargeson and John Mulgan in the nineteen-thirties, situating them as precursors of the blossoming field. Consequently, the received version of New Zealand literature did not participate in the Gothic 'waves' of the late eighteenth, and mid and late nineteenth centuries. Where other national Gothics typically look back to these earlier texts and frame them as having an originary role, the same manoeuvre is not really available in New Zealand.

Just as a genre like the Gothic comes with a mesh of ideas that help us understand texts so categorised, so too does New Zealand literature. In 1960, Allen Curnow wrote that New Zealand poetry was 'in search of reality', a reality that 'must be local and special'; he felt that the best New Zealand poetry is 'marked or moulded' by the nature of the country itself, and that the best artists identified themselves as New Zealanders. ${ }^{32}$ In Curnow's view, to create poetry of genuine worth in New Zealand, the poet must first engage with New Zealand. It is still an idea that carries considerable force; only recently Patrick Evans worried about the emergence of a

\footnotetext{
${ }^{31}$ Jane Stafford and Mark Williams, Maoriland: New Zealand Literature 1872-1914 (Wellington: Victoria UP, 2006).

${ }^{32}$ Allen Curnow, Introduction, The Penguin Book of New Zealand Verse, ed. Allen Curnow (Harmondsworth: Penguin, 1960) 17.
} 
school of youngish Wellington writers who aspired to what he felt was bland internationalism rather than an appropriately local literature. ${ }^{33}$ Claims like these indicate that a field is operating, where values are attributed according to how writers perform a specifically New Zealand rather than a more general literary practice.

Participants have been able to define the field, including some values and practices while excluding others. Readers familiar with New Zealand literature look for the things indicative of that practice, including settler anxieties, postcolonial negotiations of occupancy, engagements with Maori culture, local idioms, a strong line in critical realism, often a repudiation of Protestant or other traditional value structures, and a desire for authenticity of representation; New Zealand literature is expected to be highly mimetic. On the other hand, Curnow's excoriation of the naïve bush Romanticism of 'kowhai gold' poetry ${ }^{34}$ has essentially excluded it from the New Zealand canon. The field functions to promote these generalised views.

The values attached to New Zealand literature become enshrined, even if uncomfortably, in critical discussions. As Michael Morrissey writes, 'Whether ultimately desirable or not, the 'mainstream' with its incumbent realism of one mode or another... still tends to dominate our literary landscape. ${ }^{35}$ One of the major values attached to canonical New Zealand literature can often be usefully described by reference to the idea of 'critical realism'. ${ }^{36}$

The critical realist literature of New Zealand is understood as being interested in presenting the 'real', but also in critiquing it. Realism is a practice we understand as loosely interested in depicting a truth. When we read critical realism, we expect to

\footnotetext{
${ }^{33}$ Patrick Evans, "Baby Factory," New Zealand Listener 16-22 August 2003: 50-3.

${ }^{34}$ Allen Curnow, "Aspects of New Zealand Poetry," Look Back Harder: Critical Writings 1935-1984, ed. Peter Simpson (Auckland: Auckland UP, 1987); Allen Curnow, "Introduction to A Book of New Zealand Verse 1923-45" Look Back Harder: Critical Writings 1935-1984, ed. Peter Simpson
} (Auckland: Auckland UP, 1987).

${ }^{35}$ Michael Morrissey, Introduction, The Flamingo Anthology of New Zealand Short Stories, ed. Michael Morrissey (Auckland: Flamingo, 2000) 19.

${ }^{36}$ Williams, Leaving the Highway 31. 
see a lesser truth outshined by a greater truth. Sargeson's 'The Hole that Jack Dug', 37 where Jack, much to the irritation of his wife, eccentrically digs a large hole in the garden for no discernable reason, tells us something 'true' about New Zealand, at the same time as suggesting that there is something unpleasantly stifling in the values espoused by Jack's wife. Our day-to-day lives might be like Jack's wife's; but we recognise that Jack is livelier, more authentic than his wife. Likewise, reading James K Baxter's Pig Island Letters, we enjoy both recognising New Zealand and seeing its inhabitants castigated. Baxter informs his readers that 'How often Remuera girls abort / Has not been mentioned in the Hunn Report. ${ }^{38}$ We are presented with a truth that contradicts the 'official version', and while readers might be scandalised, we are more likely to derive pleasure from feeling as if we are party to a 'truer' truth. Critical realism implies this position of greater truth, of greater authority; one where a text describes how what it shows is truer than the audience's perception of the real.

If we accept Benedict Anderson's argument, that print culture is one of the important things which helps us create a sense of nation-ness, the imagined community that we inhabit, ${ }^{39}$ then a national tradition of writing which concentrates on critical realism is always going to make us feel a little uneasy; however, unease is not the same as the Gothic. In fact, critical realism is anathema to the escapism, campness, and inauthenticity of the Gothic, and this has interesting consequences for our ability to identify the Gothic in New Zealand texts. The Gothic, with its interest in the abnormal and irrational, is not well equipped to deliver a critical position. Despite the attempts of Gothic studies to frame it as such, the Gothic's social critique is incidental rather than characteristic. Neither Horace Walpole nor Anne Rice is interested in representing the world at its most strikingly authentic. If the Gothic is at its most recognisable when it is at its least mimetic, then identifying it within a tradition that stresses critical realism is going to create tensions. This possibly

\footnotetext{
${ }^{37}$ Frank Sargeson, "The Hole That Jack Dug," The Stories of Frank Sargeson (Auckland: Penguin, 1982).

${ }^{38}$ James K. Baxter, "Pig Island Letters," Collected Poems, ed. J.E. Weir (Wellington: Oxford UP, 1979) 279.

${ }^{39}$ Benedict Anderson, Imagined Communities: Reflections on the Origin and Spread of Nationalism, Revised ed. (London: Verso, 1991).
} 
explains why articles that treat the Gothic have tended to locate it at some distance from the centre of the New Zealand literary canon.

Another point is that New Zealand's tradition of critical realism developed in the wake of international modernism. Modernism has tended to be inimical to notions of genre, ${ }^{40}$ as have discussions of New Zealand literature. Genre has even become a pejorative evaluation in some critical practice. This can be illustrated in critical responses to a writer like Ngaio Marsh. Marsh must be one of the most-read New Zealand writers in an international context, but her popular detective fictions have had difficulty maintaining any kind of stature in New Zealand. Her entry in The Oxford Companion to New Zealand Literature suggests that the English settings of her detective fiction 'provided an escape from the more demanding task of establishing a New Zealand novel tradition. ${ }^{41}$ This assessment is puzzling. Why should we compare Marsh's detective fiction to the 'New Zealand novel'? Nobody suggests that Agatha Christie is where we ought to begin a conversation about the English novel. Marsh herself described detective fiction as a 'queer, circumscribed, and isolated form' $;{ }^{42}$ her texts were never intended to take the role of the great New Zealand novel. By overemphasising New Zealand literature as a reading frame, we risk misunderstanding fictions that participate primarily in genres other than 'New Zealand literature'.

Although the focus on New Zealand literature has meant that the role of genres like the Gothic has been underemphasised, there have nevertheless been richly Gothic seams running through New Zealand literary tradition since its inception. Some of Mansfield's early prose-poetry draws heavily on a Wildean, decadent version of the Gothic; and in another mode entirely, she gives us the wholly local and classically Gothic, twist-in-the-tale of 'The Woman at the Store. ${ }^{43}$ Maurice Duggan's

\footnotetext{
${ }^{40}$ Duff, "Introduction" 1.

${ }^{41}$ Nelson Wattie, "Marsh, Ngaio," The Oxford Companion to New Zealand Literature, eds. Roger Robinson and Nelson Wattie (Melbourne: Oxford UP, 1998) 360.

${ }^{42}$ Ngaio Marsh, "Is the Detective Story Dying?" New Zealand Listener 17 October 1947: 8.

${ }^{43}$ Katherine Mansfield, "The Woman at the Store," The Collected Stories (London: Penguin, 2007); Katherine Mansfield, "Study: The Death of a Rose," The Triad 1 July 1908; Katherine Mansfield,
} 
'Notes On An Abstract Arachnid' is essentially a modernist lustmord. ${ }^{44}$ Terrible disappearances trouble the ossuary in Dennis McEldowney's 'By the Lake'. ${ }^{45}$ Witi Ihimaera's 'Dustbins' is a shocker about incest and an attempt to dispose of a stillliving baby. ${ }^{46}$ Baxter's poetry is thoroughly haunted. ${ }^{47}$ And how far from Hawthorne's monstrous Puritan hypocrites are Bill Pearson's fretful sleepers, with their 'willingness to persecute those who don't conform'? ${ }^{48}$ Maurice Gee's Under the Mountain is close to being Lovecraft for children, Elizabeth Knox has written a vampire novel, Daylight, and Ronald Hugh Morrieson's The Scarecrow features an authentically New Zealand Gothic villain in the form of Salter, the murderous magician. ${ }^{49}$ Taken together, these texts present an opportunity to form a more coherent New Zealand Gothic than the strained eclecticism of Gothic NZ. Perhaps unexpectedly, Frank Sargeson, generally regarded as the paterfamilias of New Zealand's cobber-lit, is a good place to begin this project.

"Silhouettes," Katherine Mansfield: Publications in Australia 1907-09, ed. Jean E. Stone (Sydney: Wentworth Books, 1977).

${ }^{44}$ Maurice Duggan, "Notes on an Abstract Arachnid," Collected Stories, ed. C.K. Stead (Auckland: Auckland UP: Auckland: Oxford UP, 1981).

${ }^{45}$ Dennis McEldowney, "By the Lake," Classic New Zealand Short Stories, 1953. ed. Dan Davin (Auckland: Oxford UP, 1997).

${ }^{46}$ Witi Ihimaera, "Dustbins," Ihimaera: His Best Stories (Auckland: Reed, 2003).

${ }^{47}$ See for instance, James K. Baxter, "The Dark Side," "The Woman on the Stair," and "Sestina of the Makutu," Collected Poems, ed. J.E. Weir (Wellington: Oxford UP, 1979).

${ }^{48}$ Bill Pearson, "Fretful Sleepers," Great New Zealand Argument: Ideas About Ourselves, ed. Russell Brown (Auckland: Activity Press, 2005) 55.

${ }^{49}$ Maurice Gee, Under the Mountain (Wellington: Oxford UP, 1979). Elizabeth Knox, Daylight (Wellington: Victoria UP, 2003). Ronald Hugh Morrieson, The Scarecrow: A Novel (Sydney: Angus and Robertson, 1963). 


\section{Frank Sargeson's Gothic}

Frank Sargeson, a staunch critical realist, is thought to represent an authentic view of New Zealand, addressing themes of emergent nationhood and capturing the vernacular. ${ }^{50}$ Lydia Wevers suggests that 'More than any other writer, the work of Frank Sargeson signifies New Zealandness in our literature. ${ }^{51}$ Williams emphasises that the 'method of reading Sargeson's stories' established by a number of critics has enshrined the perception they offer 'an unrivalled apprehension of New Zealandness'. ${ }^{52}$ Stuart Murray also asserts the national-ness of Sargeson, but also notes that he is one writer who has proved remarkably adaptable to various critical models. ${ }^{53}$ These understandings begin to form a 'received view' of how to read Sargeson.

That Sargeson may not seem an apt writer in which to discover the New Zealand Gothic proves this point; we have required him to represent New Zealand literature. This view may have been widened through revisionist readings that focus on the 'discovery' of Sargeson's homosexuality. ${ }^{54}$ Thus, in addition to understanding Sargeson as a 'New Zealand writer', we understand him as a 'queer writer' too.

\footnotetext{
${ }^{50}$ R. A. Copland, Frank Sargeson, New Zealand Writers and Their Work (Wellington: Oxford UP, 1976) 9-10; Philip Wilson, "Apprentice," Islands 6.3 (1978); Lawrence Jones, "Once Is Not Enough: On Re-Reading Sargeson," Islands 6.3 (1978); Lawrence Jones, "Frank Sargeson and the Great New Zealand Novel," Journal of New Zealand Literature 16 (1998); Patrick Evans, "On Originality: No Earth Tones," Writing at the Edge of the Universe, ed. Mark Williams (Christchurch: Canterbury UP, 2004) 75 .

${ }^{51}$ Lydia Wevers, "The Short Story," The Oxford History of New Zealand Literature in English, ed. Terry Sturm, 2nd ed. (Auckland: Oxford UP, 1998) 263.

${ }^{52}$ Mark Williams, "Literary Scholarship, Criticism and Theory," The Oxford History of New Zealand Literature in English, ed. Terry Sturm, 2nd ed. (Auckland: Oxford UP, 1998) 714.

${ }^{53}$ Stuart Murray, Never a Soul at Home: New Zealand Literary Nationalism and the 1930s (Wellington: Victoria UP, 1998) 138, 142.

${ }^{54}$ Kai Jensen, "Frank at Last," Opening the Book: New Essays on New Zealand Writing, eds. Mark Williams and Michele Leggott (Auckland: Auckland UP, 1995); Bruce Harding, "The Oil on the Salad or, 'Being Frank About Frank: The Conjunction of Religious and Judicial Legalisms and The "Sodomite Rule" in Frank Sargeson's Life and in The Hangover (1967)'," Journal of New Zealand
} 
The problem is that, as George Lakoff demonstrates, categories exclude as much as they define. ${ }^{55}$ These reading frames have directed attention towards certain aspects of Sargeson's writing, such as representations of the vernacular and mateship, and in doing so, direct attention away from other elements, such as the Gothic. This is not to say that critics have been oblivious to the macabre in Sargeson; Williams notes the 'gothic, macabre, and bizarre touches throughout Sargeson's writing, 56 but regards them as precisely that, 'touches', rather than as a substantive quality.

Beginning with the stories, we might note they frequently depict violence, as Joost Daalder has. ${ }^{57}$ Violence is one thing, but the violence in Sargeson is frequently loaded with perversity. For instance, 'A Good Boy' is a tale told in the first person by an unnamed narrator, who is perhaps mad; it is a confession in the aftermath of a murder, and operates around a simple moral twist. The narrator begins with the words 'I never wanted to be a good boy', ${ }^{58}$ meaning that he never wanted to be the sort of person his dull, zealously Protestant parents wanted him to be. Instead, he admires 'good sorts', especially the Irish (Catholic?) bookmaker and his wife who run a billiard hall. ${ }^{59}$ Gaming and gambling are unacceptable to the Protestant ethic, yet attract the narrator; the lively 'good sort' is contrasted with the dour, Protestant 'good boy'. Perversely, the narrator describes killing his unfaithful girlfriend as doing the morally right thing:

Gosh, when I killed the girl I felt better and cleaner than I've ever felt in my life. I bet father used to feel just the same as I did when he used to give me those hidings. I never wanted to be a good boy,

Literature 16 (1998). See also the concern that this has simply 'replaced' nationalist readings of Sargeson in Murray, 143.

${ }^{55}$ Lakoff.

${ }^{56}$ Williams, Leaving the Highway 25.

${ }^{57}$ Joost Daalder, "Violence in the Stories of Frank Sargeson," Journal of New Zealand Literature. 4 (1986).

${ }^{58}$ Frank Sargeson, "A Good Boy," The Stories of Frank Sargeson (Auckland: Penguin, 1982) 26.

${ }^{59}$ Sargeson, "A Good Boy" 27. 
but when it came to a sort of test I found I was a good boy after all.

I did the right thing. I've told the detectives and the lawyers and the doctors and everybody that over and over again, and they won't believe me. You'd almost believe they think I'm off my block which is just plum ridiculous. I've told them I've never been a good boy, all except one time when I did the right thing just like father and mother had always tried to teach me. That was the time I killed that girl. ${ }^{60}$

Coming at almost the conclusion of the text, the revelation that the narrator is a murderer comes as a surprise. The sudden release of withheld information at the end forces us to radically reread the tale. The narrator had seemed more sympathetic, livelier than his parents; but now the reader is in a bind. We sympathise with the narrator, but cannot approve what he has done. Our sympathies are at odds with our moral sense, our feelings do not reconcile with what we know to be right. Can we accept his account, where he blames the 'goodness' instilled in him by his parents for his behaviour? The narrator argues that by killing the girl he has been a 'good boy', not a 'good sort'. Yet if we accept this argument, we have to reject values which, certainly at the time of its original publication in $1935,{ }^{61}$ were held dear by decent, honest, hard-working people.

While there is an element of moral critique in 'A Good Boy' consistent with the view of Sargeson as a critical realist, the argument made by the narrator is basically facetious. Its satirical acuity is diminished by its absurdity. Sargeson's critique relates to the real problem of a buttoned-down New Zealand culture, but gestures towards the morbid fancies of the Gothic, suggesting the narrator's parents would approve his action. Readers are encouraged to play out a Gothic possibility more than experience a serious moral crisis, feeling the attraction of wickedness, if only for a moment.

\footnotetext{
${ }^{60}$ Sargeson, "A Good Boy" 28-9.

${ }^{61}$ J. W. Hayward, Frank Sargeson: An Annotated Bibliography: Works and Critical Comment

(Wellington: Library School, National Library of New Zealand, 1975) 19.
} 
Poe explores this kind of perversity in 'The Imp of the Perverse'. ${ }^{62}$ It is a mixed form, part tale and part essay. The narrator describes the eponymous imp, an irresistible impulse that drives us toward immoral action, and recounts that it drove him to commit an as-yet undetected murder. However, he falls prey to the action of the imp again and is driven to unaccountably confess. The twist in the tale's ending relates to perverseness as a quality; while it motivates villainy, it turns upon itself and facilitates the execution of justice too.

'A Good Boy' is a kind of mirror image of 'The Imp of the Perverse'. It too is a confessional tale recounted in the first person by a murderer who has been apprehended; and it too isolates a single quality that exists within the narrator as the motivating force of the murder. Both are murder ballads in prose, which elicit a degree of sympathy for their murderers as they fret that they have been misunderstood. However, where Poe blames perversity, Sargeson, more perversely, blames goodness. Poe's murderer acts upon his uncontrolled desires, while Sargeson's re-enacts the authoritarian violence that has been directed toward him. A Freudian analysis might suggest that Poe points to the dangers of the id; Sargeson, contrarily, points to the dangers of the superego.

In fact, Poe is a substantial, although unrecognised, point of reference for Sargeson's stories. Poe is even explicitly discussed in 'Letter to a Friend', in which a very thinly disguised representation of Sargeson himself discusses Poe's Tales with an attractive young man at a beachside holiday spot. ${ }^{63}$

"A Great Day ${ }^{64}$ is another story central to the Sargeson canon that appears to draw directly from one of Poe's tales. The story's title employs the same ironic sensibility that 'A Good Boy' does; it describes how Fred murders his friend Ken on a fishing trip. Fred knows that Ken cannot swim, and deliberately strands him on a reef at low tide, with the weather worsening. Fred, a confident swimmer, rows away, then capsizes the dinghy to make the murder seem like an accident. Structurally it is very

\footnotetext{
${ }^{62}$ Edgar Allan Poe, "The Imp of the Perverse," Collected Works of Edgar Allan Poe, ed. Thomas Ollive Mabbott, vol. 3 (Cambridge, MA: The Belknap P of Harvard UP, 1978).

${ }^{63}$ Frank Sargeson, "Letter to a Friend," The Stories of Frank Sargeson (Auckland: Penguin, 1982).

${ }^{64}$ Frank Sargeson, "A Great Day," The Stories of Frank Sargeson (Auckland: Penguin, 1982).
} 
similar to Poe's 'The Cask of Amontillado'. ${ }^{65}$ As in Poe's tale, the exact reason for the murder is withheld, although in both there is a sense the victim has somehow slighted the murderer. In both stories, the victim is lured into danger with the promise of some degustatory reward offered by their killer; Fortunato seeks a taste of Amontillado, Ken would like some mussels. The nicely appalling detail at the end of the Sargeson, where Fred shuts his eyes and rows away, his ears stuffed with cotton wool, ${ }^{66}$ so that he is unable to see or hear Ken, who is stranded, unable to swim, and quite doomed, is not dissimilar to the ending of Poe's story. Fortunato, walled up, is finally silent and has been obscured from view. Both Fred and Montresor premeditate murders that involve not only trapping their victims but obscuring their death, beneath walls or water. New Zealand might not provide sufficiently extensive dungeons in which to immure the hapless, but the sea provides a pleasing alternate, and perhaps paves the way for Frame's tale of concealed murder by drowning, 'The Lagoon. ${ }^{, 67}$ 'Sale Day' ${ }^{68}$ is also marked by strange violence and inscrutable motives. It troubled readers when it first appeared; what was Sargeson getting at? ${ }^{69}$ Kendrick Smithyman, baffled, attempted to read it as a discursive modernist gesture, without recourse to the Gothic. In this tale, Victor's family is away at a sale day; he goes to their farmhouse's kitchen and menaces Elsie, who chars for them. Victor seems to want to bed Elsie, but she is unenthusiastic, and engaged to another man. Victor puts the pet cat in the fire and jams a pan down on top of it. In the distance, they hear the family car returning; Victor warns Elsie that she should get another job before it is sale day again in a fortnight's time, when she will again be alone with him.

Daalder reads 'Sale Day' as being heavily derived from D.H. Lawrence's short novel, The Fox, arguing that Sargeson chooses a cat instead of a fox because he

\footnotetext{
${ }^{65}$ Edgar Allan Poe, "The Cask of Amontillado," Collected Works of Edgar Allan Poe, ed. Thomas Ollive Mabbott, vol. 3 (Cambridge, MA and London: The Belknap P of Harvard UP, 1978).

${ }^{66}$ Sargeson, "A Great Day" 75.

${ }^{67}$ Janet Frame, "The Lagoon," The Lagoon and Other Stories (Christchurch: The Caxton P, 1961).

${ }^{68}$ Frank Sargeson, "Sale Day," The Stories of Frank Sargeson (Auckland: Penguin, 1982).

${ }^{69}$ Kendrick Smithyman, "A Sort of Poet Too," Islands 6.3 (1978): 299.
} 
did not want to be seen as slavishly imitative. ${ }^{70}$ If Daalder had pursued this argument, he might have discovered an even better reason is that there are no foxes in New Zealand. No matter; Daalder develops a Lawrentian reading that emphasises the story's treatment of relationships and its exploration of the 'male sensual will'. ${ }^{71}$ This troublingly conflates male sexual desire with sexual violence; it is difficult to tell if Daalder misses the threatened rape that the story hinges on, or if he sees this conflation as a critique of patriarchal structures. In any case, for Daalder, the unfortunate tom is equivalent to his reading of Lawrence's fox, an animal that provides a metaphorical frame for male sexual desire. This rather misses the point that foxes are wild animals that have traditionally been hunted, whereas cats are domesticated and claim a position of belongingness within a household. Daalder's reading struggles for connections that are not there; yet the field's understanding of Sargeson allowed and even encouraged a reading like this one, linking him to Lawrence's serious-minded realism.

A more obvious point of comparison for 'Sale Day' is Poe's 'The Black Cat', which, like the Sargeson, describes 'a series of mere household events', ${ }^{72}$ along with other substantial similarities. It too features a violent man killing a cat; in the Poe, he also kills his wife, whereas in the Sargeson, he only threatens the female object of his desire. After Pluto, the first of the two cats in 'The Black Cat', is killed, the narrator's house burns down; in 'Sale Day' the cat dies in the kitchen fire.

Poe provides no cause for his narrator's violent action outside of liquor, a general baseness, and 'PERVERSENESS', recalling 'The Imp of the Perverse'. Poe's narrator complains that 'Of this spirit philosophy takes no account. ${ }^{, 73}$ Perverseness exists before rationality and contrary to it, a primal human urge. Although Sargeson is more oblique, in that we are not provided with Victor's account of his actions, he

\footnotetext{
${ }^{70}$ Daalder 61.

${ }^{71}$ Daalder 62.

${ }^{72}$ Edgar Allan Poe, "The Black Cat," Collected Works of Edgar Allan Poe, ed. Thomas Ollive Mabbott, vol. 3 (Cambridge, MA and London: The Belknap Press of Harvard University Press, 1978) 849 .

${ }^{73}$ Poe, "The Black Cat" 852.
} 
seems to be motivated by an unaccountable, in this case explicitly sexually violent, urge.

The poor cats hold similarities too. In both the Poe and the Sargeson, the cat is repeatedly labelled a 'brute', ${ }^{74}$ despite it being a slightly unusual descriptor for a pet, and in both cases there is a play on the word's dual meanings of 'animal' and 'thug'. In the Poe, the narrator explicitly compares himself to the 'brute beast', emphasising his superiority to the animal because he has been fashioned in the image of God. At the same time he worries that he will be damned for his 'sin' in killing the cat, an act he fears exists outside of God's capacity for mercy. ${ }^{75}$ The cat, by comparison, seems an innocent rather than a brute. In the Sargeson, the comparison is less explicit; Victor complains that the cat is a 'randy brute' while stroking himself in an animalistic fashion and pressuring Elsie for sex. Human brutishness is linked to animal bruteness; both Poe's narrator and Victor are more brutish than the animals they kill.

Although there are similarities between the two tales, there are significant divergences too. In 'The Black Cat', when the narrator goes to strike the second black cat his wife intervenes, and she is killed instead. In 'Sale Day', Victor wants to have sex with Elsie, and if she will not consent, he intends to rape her; instead the cat becomes the focus of his aggression. In the Poe, the second cat becomes the agent of justice after the murder, while in the Sargeson, the cat becomes a sacrifice that protects Elsie from Victor's aggression. Poe's sense of justice is demonstrative and didactic, while Sargeson withholds the narrative satisfaction of seeing Victor rebuked. Interestingly, 'Sale Day' suggests a complication of the Sargesonian pattern, evident in his Gothics ('A Good Boy', for instance) and his non-Gothic tales ('Conversation with my Uncle', 'The Hole that Jack Dug'), where liveliness is shown to be preferable to the reserved, respectable and prim. It is Victor who is charged with life and desire, and Elsie who is more reserved, yet despite Daalder's attempt to frame Victor as a Lawrentian hero, we cannot possibly find anything appealing about him. Even Victor recognises that his inability to control his 'natural' urges is problematic; 'Living all your life on a farm you see too damn much of nature... It's no good if

\footnotetext{
${ }^{74}$ Poe, "The Black Cat" 852, 855, 856; Sargeson, "Sale Day" 96, 97.

${ }^{75}$ Poe, "The Black Cat" 852, 855.
} 
you've got a sensitive nature yourself. ${ }^{76}$ Yet his plea that his sensitive nature be recognised marks him as a monstrous, wheedling hypocrite; this is man about to brutally kill a cat, who plans to rape the woman he is speaking to. Liveliness here crosses into viciousness.

Sargeson's Gothics are not confined to reworkings of Poe's. There is the midnight burial of the child beneath the macrocarpas at the heart of 'The Undertaker's Story'. "“Gods Live in Woods"” takes its name from a refrain in one of E.M. Forster's weird tales, 'Other Kingdom'. ${ }^{78}$ Both are narratives of a disappearance in a haunted wood, or more accurately, in the New Zealand context, the haunted bush. Where Forster's tale refers the supernaturalism of the woods to classical myth, Sargeson populates his bush with weta, native insects, and claims 'The Maoris call them taipos', ${ }^{79}$ a type of inhuman spook or goblin. Even if this is a postcolonial appropriation of Maori lore, it is also an attempt at a genuinely indigenous haunting.

Sargeson's tales point towards locales that facilitate the practice of a New Zealand Gothic. In some cases, as with the bush of "“Gods Live in Woods", it might hark back to the Italian forests of the British Gothic, or Hawthorne's haunted woods. In others, there is no such precedent, and Sargeson begins to improvise a genuinely new New Zealand Gothic.

An especially impressive example of Sargeson's ability to employ the New Zealand milieu in genre practice is the shearing shed Gothic of 'I've Lost my Pal'. ${ }^{80}$ The narrator and his friend Tom help on a shearing gang, where they meet George. After work, they sit on a woodpile, yarning in the moonlight. George likes to wash himself in front of everyone, and is unusually concerned with personal grooming for a

\footnotetext{
${ }^{76}$ Sargeson, "Sale Day" 97.

${ }^{77}$ Frank Sargeson, "The Undertaker's Story," The Stories of Frank Sargeson (Auckland: Penguin, 1982).

${ }^{78}$ Frank Sargeson, "'Gods Live in Woods'," The Stories of Frank Sargeson (Auckland: Penguin, 1982); E.M. Forster, "Other Kingdom," The New Collected Short Stories (London: Sidgwick \& Jackson, 1985).

${ }^{79}$ Sargeson, "'Gods Live in Woods"' 231.

${ }^{80}$ Frank Sargeson, "I've Lost My Pal," The Stories of Frank Sargeson (Auckland: Penguin, 1982).
} 
shearer; he actually dresses to sit on the woodpile. We presume George is homosexual when he says he has been the 'pet' of a Sunday school teacher. He also has a nasty temper, often mistreating the lambs. Tom disapproves of George, and is annoyed that he boasts that he killed an old man recently found dead in a swamp, or, at least that he knows who is responsible. Tom goes missing, and the narrator reports

I hadn't got up off the woodpile before George began walking over to the dog. It barked blue murder the nearer he got to it, and if it didn't do the maddest dance you ever saw on the end of its chain! How George managed to get on it, I don't know, but he did. There was a bosker moon, like I've said, and I just sat on that woodpile and watched George strangle the dog. I couldn't move. I couldn't. You see I knew then what had happened to Tom. For the life of me I couldn't move. ${ }^{81}$

The tale concludes with George 'going down' for Tom's murder.

This seems an excellent instance of the convergence of two distinct practices in a single passage of text. Not only does Sargeson succeed in representing a pungently parochial idiom, but he deploys it to considerable Gothic effect. As the dog barks blue murder, we are reminded of the old man found murdered in the swamp, and the revelation of Tom's death is prefigured. The dog's mad dance exists in contrast to the stillness of the narrator, the bosker moon is counterpointed by a man strangling a dog, and a mental insight is experienced in the narrator's body. It is a moment of beauty and horrifying cruelty and sudden, ghastly, disabling knowledge. It is a deeply Gothic arrangement, and a uniquely New Zealand one.

Daalder remarks of 'I've Lost My Pal' that

The basic opposition in the story is the very common Sargesonian one of 'life-stifling materialistic protestant' versus 'unorthodox,

\footnotetext{
${ }^{81}$ Sargeson, "I've Lost My Pal" 34.
} 
somewhat muddled-up but basically humane and innocent child or childlike outsider'. ${ }^{82}$

This makes stories like 'I've Lost My Pal' and 'A Good Boy' seem wholly congruous with many of Sargeson's other stories, and emphasises his critique of the puritanical elements of New Zealand culture, locating these tales within the 'critical realist' tradition. However, this misses the morbid extremes these stories go to, the ways in which they mark themselves apart from the more benign scenarios of 'Conversation with My Uncle' or 'The Hole that Jack Dug'. To see these other stories as basically continuous with Sargeson's Gothics de-emphasises those elements that mark the stories out as different, flattening Sargeson's range as a writer. It also oversimplifies the narrator's relationship with George.

The narrator is wary of George, yet often finds him admirable, actually seeming to be attracted to him. He notes that when George washes himself in front of the rest of the gang, he 'was pleased at the things we used to say about the different parts of him. He had a corker body anyhow. ${ }^{83}$ The narrator does not judge George's confrontational sexuality, and instead dwells on George's pleasure in the public, male scrutiny of his body. There is a cheeky frisson in his reluctance to name the exact parts of George's body being praised, and in the use of language we associate with the masculinist, heterosexual, conservative New Zealand of the thirties, 'corker', to describe a vaguely sexual admiration.

The narrator goes on to defend George's viciousness toward the lambs, a point likely to trouble readers. Tom has exclaimed at George's cruelty to a lamb, after George throws it against a wall so that it falls, inert, to the floor:

[George] sort of looked pleased like he had looked that other time when he had Tom thinking things about the old man who was found dead in the swamp. And the next lamb he sheared Tom and I saw him rip the poor little bugger right across the belly. Well, maybe it was an accident, but you sort of felt that George was a bit

\footnotetext{
${ }^{82}$ Daalder 59.

${ }^{83}$ Sargeson, "I've Lost My Pal" 30.
} 
pleased. Tom went outside and he stayed outside longer than he ought, but I didn't blame him. I didn't blame George either. Well, I did a bit, but you can't expect a shearer to pick up a lamb in his arms and nurse it. Can you now ${ }^{84}$

The 'Can you now?' is a provocation to the reader as sure as George's pleasure in washing himself in front of the gang is to the shearers. Rather than simply dismissing George's behaviour as cruel and unconscionable, the narrator asks us to excuse him by appealing to a sense of pragmatism rooted in New Zealand's farming culture. This is an accusation as much as a question; if we have a problem with George's sadism, the narrator suggests, we do not understand the country.

The narrator remains inside with George rather than going outside with Tom. He spends more effort defending George's action than he does Tom's disgust, indicating a preference for George. At the same time, the idea of the dead man in the swamp recurs here, explicitly linked to George's pleasure in his own capacity for cruelty.

A similar defence emerges for George's murder of Tom. Our sympathy for Tom has already been undermined when the narrator observes 'there always was a sort of goody-goody streak' in him; ${ }^{85}$ and even if George does 'get maggoty' sometimes, how can we dislike a shearer who dresses to sit atop a moonlit woodpile crooning Bing Crosby songs? Compared to the flatness of Tom and the narrator, the vivid depiction of George appeals, even if we are appalled by his actions. Finally, the narrator reflects

I'm sore at losing Tom. I am that. But I have to admit that he'd sometimes get on your nerves and make you feel tired by arguing silly. Haven't you ever felt like that with anyone? Own up. I bet you have. ${ }^{86}$

\footnotetext{
${ }^{84}$ Sargeson, "I've Lost My Pal" 33.

${ }^{85}$ Sargeson, "I've Lost My Pal" 32.

${ }^{86}$ Sargeson, "I've Lost My Pal" 34.
} 
As with 'A Good Boy' and 'A Great Day', a sharp irony becomes apparent in the tale's title; the pal being referred to is George, not Tom.

As with 'A Good Boy', the narrator ends by attempting to justify a murder. He is sore at losing Tom, but nothing like sympathy is extended towards his dead friend, and the colloquial turn of phrase is somewhat flippant as an expression of grief. Instead, the narrator attempts to involve us in the moral problem of the murder. Have we not felt the same way about someone that George felt about Tom? Does that not make us as bad as him? The conceit is similar to that at the ending of 'A Good Boy', where sympathy is elicited for the villain. We cannot take the argument of 'I've Lost my Pal' seriously because it does not identify the difference between feeling irritation, and murderously acting upon a feeling of irritation. However, this is to miss the point that it is not an argument meant to be taken seriously. The appeal the narrator makes does not have a moral basis, but rather a charismatic one. Our interest lies in George, who, more than Tom and the narrator, provides the basis of the story. It is the ability of George to entertain us that motivates our reading. In the real, we condemn figures like George, but when we read the Gothic text, our Gothic habitus allows us another approach, where we prefer the bad man to the good. In this way, Sargeson's Gothic celebrates Poe's imp of the perverse, embracing the wrong thing rather than the right. This complicates a view of Sargeson as a critical realist. Critical realism exposes a greater truth; Sargeson's Gothics still offer social critique, but ultimately tend to murderousness and gleeful perversity, thus reducing the substance of that critique.

George is wicked, but also wickedly appealing. With the benefit of hindsight, we can see that Sargeson obviously had some sympathy with his homosexual characters, as does his narrator, who might even be queer himself. At the same time, homosexuality is linked to violent criminality and insurmountable difference, as it will also be in The Hangover. However, George's otherness is not wholly grounded in his homosexuality; he is also unusually sensitive. We learn that George 'said he could stand anything except things that got on his nerves. If anything got on his nerves, well, look out! ${ }^{87}$ He also complains of people who make him feel tired. Victor, in 'Sale Day' also complains of his sensitivity. ${ }^{88}$ This inability to cope with regular

\footnotetext{
${ }^{87}$ Sargeson, "I've Lost My Pal" 31.

${ }^{88}$ Sargeson, "Sale Day" 97.
} 
sensations, in George's case, the barking of a dog, is much like the Gothic sensitivity exemplified by Roderick Usher's nerves, described by Poe as a 'morbid acuteness of the senses'. ${ }^{89}$ Gothic figures often encounter unusual and overwhelming sensations and dissociate themselves from the everyday world. A further twist at the close of 'I've Lost my Pal' is that the narrator seems to adopt this sensitivity, mimicking George by complaining that Tom got on his nerves and made him tired. As the narrator poses his last question, we are invited to admit that we too are in possession of this Gothic sensibility.

The Hangover, published in London in 1967, is one of Sargeson's least discussed works, receiving little critical attention compared to the stories and longer pieces like 'That Summer'. It is difficult, of course, to chronicle an absence, but it is worth noting it is barely mentioned in King's biography, in the issue of Islands that was given over to a Sargeson festschrift (and then, only in a review of a critical text), or in the recent tribute, An Affair of the Heart. ${ }^{90}$ It is mentioned for the sake of completeness in The Oxford Companion to New Zealand Literature, but remains unexplored. ${ }^{91}$ The Hangover does not substantially contribute to Sargeson's reputation. However, it is treated in R A Copland's study of the author. ${ }^{92}$ More recently, the most substantial treatment the novella has received is Bruce Harding's article. ${ }^{93}$

${ }^{89}$ Edgar Allan Poe, "The Fall of the House of Usher," Collected Works of Edgar Allan Poe, ed. Thomas Ollive Mabbott, vol 2 (Cambridge, MA and London: The Belknap P of Harvard UP, 1978) 403.

${ }^{90}$ Michael King, Frank Sargeson: A Life (Auckland: Viking, 1995); Robin Dudding, ed., In Celebration, for Frank Sargeson at 75, spec. issue of Islands, 6.3 (1978); Dennis McEldowney, rev. "Ways of Reading: Frank Sargeson by R.A. Copland," Islands. 6.3 (1978); Graeme Lay and Stephen Stratford, eds., An Affair of the Heart: A Celebration of Frank Sargeson's Centenary (Auckland: Cape Catley, 2003).

${ }^{91}$ William Broughton, "Sargeson, Frank," The Oxford Companion to New Zealand Literature, eds. Roger Robinson and Nelson Wattie (Melbourne: Oxford UP, 1998).

${ }^{92}$ Copland.

${ }^{93}$ Harding, "The Oil on the Salad." 
It is, of course, inevitable that some works, even by major writers, will hold less interest than others. However, my suggestion is that The Hangover has received little critical attention because it has been misunderstood. Readers simply have not known what to make of it. The basis for my claim relates to what appears to be a serious misreading that runs throughout the critical work that treats the text. This is not simply a question of variant interpretation, but rather of completely misconstruing the text's central conceit.

The Hangover narrates the story of Alan, a repressed and virginal engineering student. Alan's widowed mother, a zealous Protestant, wants to see her good boy through his degree. Alan, however, wants to transfer his degree to the arts, even going so far as to read poetry around the house rather than his engineering texts. He is beginning to move in new circles too, with several of his friends living bohemian lives in variously unconventional and squalid arrangements. Over the summer, Alan's mother goes away to a funeral. Things go awry for him when a young girl visits his house unchaperoned, and her father, Harold Binder, accuses Alan of molesting his daughter. Binder tries to blackmail Alan, who turns to Dick Lennie, an older bohemian, for help. Dick pays Binder off and the crisis seems to be averted.

However, on her return, Alan's mother is upset because she has heard that Geoffrey, Alan's old friend, has disgraced himself. Geoffrey is from a better-off household, and had been looking forward to a profitable career as an international button collector. Something has happened involving a little girl, a lawyer is involved, and Geoffrey's mother is very worried. Alan visits Geoffrey, and shares his own experience of being wrongfully accused in similar circumstances. Geoffrey shows Alan his new machine for polishing gemstones, which he hopes will allow him to forge antique buttons, and tells Alan that he has, in fact, committed the crime he is accused of. Alan purchases four raincoats, takes his father's matchet, and murders Dick Lennie, along with the landlady and another inhabitant of the hostelry where Dick lived. Alan is a 'good boy' who tries to pass himself off as a 'good sort', but suddenly and violently fails to continue his masquerade; that is what we understand until we come to the very last paragraphs of the novella, and discover something which, if not unexpected, has at least been unclear, carefully withheld:

Lying beside a mindless automatic machine which rattled as it worked indifferently polishing gemstones, without his happy pout 
and accompanied by a discarded raincoat, Geoffrey looked forlorn and abandoned, an object to weep over.

And of course his mother immediately demanded to know where he had been, what had he been up to, and why hadn't he done for her the shopping he had promised.

And then she too screamed... ${ }^{94}$

Alan is identified as Geoffrey here, and murders his mother. That Alan is Geoffrey ought to be evident to readers. However, critical responses to the novella apparently miss this crucial twist.

Prior to the revelatory last three paragraphs of The Hangover, quoted above, we have had nothing to suggest that Geoffrey too has embarked on a raincoat-clad massacre, and Geoffrey's mother has not previously featured; Sargeson would not introduce her so obliquely. The sudden recontextualisation at the close will come as a surprise for most readers, but there are, nevertheless, plenty of earlier indicators that the two characters are one and the same. Geoffrey is seldom represented in the text, and is never integrated into a scene in which others are present. When we first meet him, Alan's only 'same-age friend of the neighbourhood', 95 the text hints that he is a delusion:

[Alan] had known Geoffrey as far back as he could remember: always there had been warmth, yet without familiarity; affection, with reserve... Geoffrey, Alan thought, wasn't real. He was something that came out of a box, a large pretty-coloured box that had cost a lot of money and had a picture on the lid. What had been inside was Geoffrey, prettier than the picture and just as unreal. And Geoffrey communicated his flavour of unreality to all that surrounded him. In his company Alan too felt unreal - and after all, despite the invisible gulf which separated them, there was much to make them mutually identical. Geoffrey too was an only

\footnotetext{
${ }^{94}$ Frank Sargeson, The Hangover (London: MacGibbon and Kee, 1967) 159-60. Ellipsis in original.

${ }^{95}$ Sargeson, The Hangover 23.
} 
child with devoted parents... And it had been an immense satisfaction to Geoffrey's parents that now in his late teens he showed all the signs of establishing himself in a vocation [as a collector of buttons]... Geoffrey's parents had insisted that before he began the travels which would enable him to make his collection unique, he must complete his formal education at the university... ${ }^{96}$

There are uncanny similarities between Geoffrey and Alan, each the other's double. More than this, Geoffrey is conspicuously less real than other characters. It is peculiar but not incredible when bohemian Solly, an aspiring pseudo-Baxterian poet, fashions himself a flax skirt and waxes philosophical to Alan beneath a fig tree, ${ }^{97}$ but Geoffrey's planned profession as a trader in rare and valuable buttons is absurd in a way that nothing else in The Hangover is.

Dick Lennie, a figure a great deal like Sargeson himself, and not coincidentally, bisexual, has worried about Alan, 'who could be wholly sure there's anybody at home to answer to that name[?]', he asks himself, and then wonders if Alan is a human being but not actually a person. ${ }^{98}$ For Dick, Alan is unable to give anything of himself or produce anything worthwhile, because there is nothing of him to give. ${ }^{99}$ Tellingly, Alan/Geoffrey is discovered next to a 'mindless automatic machine' that is polishing gemstones to create fake antique buttons, a process that transforms something we acknowledge as valuable, gemstones, into something we think of as much less valuable, fake buttons. It is an absurd reconfiguration of the process of manufacture that unmakes value, and provides a symbol that mirrors Dick's analysis of Alan's retarded humanity.

\footnotetext{
${ }^{96}$ Sargeson, The Hangover 23-4.

${ }^{97}$ Sargeson, The Hangover 80.

${ }^{98}$ Sargeson, The Hangover 146.

${ }^{99}$ Sargeson, The Hangover 148-9.
} 
Later, when the final crisis looms, Alan complains of hearing his mother's voice calling for her son, but he dismisses this as a hallucination. ${ }^{100}$ On rereading, the passage seems like a point where Geoffrey and Alan's identities almost touch, where Alan recalls something that he has experienced as Geoffrey. We might notice that when Alan's mother is worried about the predicament of 'that spoilt boy who had lived at the far end of the street', we don't have directly reported access to her speech, only to the free indirect discourse that we accept as the representation of Alan's consciousness. ${ }^{101}$ And when Alan speaks with Geoffrey about his crime, he unaccountably presumes that it is Harold Binder's daughter that Geoffrey is accused of molesting. ${ }^{102}$

Even if we were to judge this particular book by its cover, the original dust jacket of The Hangover features a substantial clue to this being a narrative of split identity. It is drawn in trippy, late-sixties acid style, and features three faces. To the left, there is a hippy girl's face seen in profile, presumably Edress. To the right, a bespectacled young man in three-quarter view has an unusually gory bleeding nose that almost bifurcates his face. Below this, there is a young, androgyne face, inexplicably halved and staring straight out at the potential reader. ${ }^{103}$

The sudden collapse of the two distinct identities into a single one means we must completely reconsider what has come before; Alan is, and always has been, a dangerous lunatic. Significantly, it means that, in addition to becoming a raincoat-clad spree killer, he is a pederast. Geoffrey's confession becomes his own; he was responsible for molesting the small girl. If we turn back to the passage where Alan apparently sent her home having used a milk bottle top to turn a penny silver for her, the evasiveness of Alan's account suddenly becomes clear. ${ }^{104}$ Why is his mother apparently worried that children might visit him while she is away? It occurs to us

\footnotetext{
${ }^{100}$ Sargeson, The Hangover 115.

${ }^{101}$ Sargeson, The Hangover 141.

102 Sargeson, The Hangover 142.

${ }^{103}$ There is a picture of this image in Dennis McEldowney, Frank Sargeson in His Time (Dunedin: John McIndoe, 1976) 62.

${ }^{104}$ Sargeson, The Hangover 66-7.
} 
now that Alan is basically in his underwear over the course of the girl's visit. And there is a final, revolting detail: we had presumed Alan sprinkled his mother's lavender water on his sheets because he is hoping to bed Edress later that afternoon. Could it be that he is actually attempting to hide the traces of his assault on the child?

There is no point in the text where we can understand Alan as reasonable or sane, even though we may have mistaken him as such on our first reading. It might be possible for readers to find sympathy for a lost but basically decent young man who has tipped over into madness, a slightly tragic figure. That sympathy is likely to evaporate when he is revealed as a child molester and massively unreliable narrator.

There cannot be any doubt that Alan is Geoffrey; but Copland's reading apparently entirely misses this point, instead arguing that

Everywhere Alan turns he has the misfortune to run into sexual deviancy posturing as enlightenment, into physical squalor convinced it is paradisal, and into theft and mendacity justifying themselves as freedom. Worse still, every denizen of the waste land appears diseased with erudition. One after another they jaw away at Alan as they loll on their slacks: filthy Jasper, dubious Dick Lennie, and Solly the noble savage, introduce Spengler, Milton, Marvell, Socrates, Plato, Dante into their talk to prove they are all spiritual princes in rags. Tugged towards defection on the one side by this embassy of troglodytes and towards conformity on the other by the prim (and pruriently prudish) nagging of his mother, Alan seeks the metaphoric lamp of Aladdin, in order to transform the barren world into splendour. (There is an occasional play on 'Alan' and on 'laddie' to keep this motif in mind.) ${ }^{105}$

To read the book in this way is to see it as a kind of failed bildungsroman, where Alan attempts to grow up but instead becomes mad, instead of as a Gothic narrative of dangerously doubled identities. Astonishingly, Copland even seems to miss that the

\footnotetext{
${ }^{105}$ Copland, 35.
} 
magic lamp is important not for its ability to grant wishes, but because it needs rubbing; Sargeson uses it as a double-entendre for Alan's orgasm. ${ }^{106}$

More recently, Harding's reading of the novel recognises that Alan is queer, but still misses the collapse of identities that is at the heart of the denouement. Harding seems to allude to the novella's involvement in the Gothic through reference to James Hogg's The Private Memoirs and Confessions of a Justified Sinner, ${ }^{107}$ but his reading is little changed by this acknowledgement. Instead, Harding lightly revises Copland's reading strategy, seeing the novella as a failing-to-come-of-age narrative. He praises

Sargeson's iron narrative control and objectivity as he charts [Alan's murderous action] without a whiff of sensationalism or crude pornography underscor[ing] his claim to be regarded as a novelist of rare and discriminating ethical sensitivity. ${ }^{108}$

Harding believes the book asks why an 'otherwise sane young man' attacks those around him; ${ }^{109}$ but again, this misses the point that Alan is Geoffrey, and at no point in the novel is he actually sane. The Hangover is all sensation and crude pornography, describing spree killing and a sexual attack on a child.

Alan and his mother are drawn in a considerably more grotesque and satiric style than the sorts of characters we are familiar with from Sargeson's stories. Certainly, there is still the capacity to read the text as an ethical critique of the dangers of repression, but despite Harding's claims, The Hangover is in no way delicate or discriminating, preferring the lurid overstatement of the Gothic.

Alan's mother is physically attracted to her son. She sits with him by the fire and lustfully recalls him the last summer without his shirt on and has an orgasm;

\footnotetext{
${ }^{106}$ Sargeson, The Hangover 125.

${ }^{107}$ Harding, "The Oil on the Salad" 61.

${ }^{108}$ Harding, "The Oil on the Salad" 58, 63-4.

${ }^{109}$ Harding, "The Oil on the Salad" 69, 65.
} 
suddenly the fire is too hot and she experiences 'the incredible pleasure of climax., 110 She warns Alan against sinking in the world as Dick Lennie, a doctor's son, now a janitor, has done; to do so would be a 'disgrace'. Alan assures her he won't be her disgrace. Yet he is; as she retires to bed, she again happily entertains incestuous feelings, muddling him with his father in her fancy. ${ }^{111}$ She is one of Pearson's fretful sleepers, but supercharged with perverted desire.

The Hangover meshes sexual repression with madness. Copland and Harding claim the thesis of the book is that because Alan is pressured and uptight, he suddenly and violently 'snaps'. In a way, they are right, but this misses the point that before the narrative begins, Alan has already created an alternate persona for himself. He is mad long prior to his purchase of the raincoats.

There is a neat match between the idea of Alan having a second persona and the sly, inferential style of the writing. It can be difficult to identify the meaning of the implied eroticism in some of the passages, as if the book too has a second, more sordid identity. This is true of Alan's mother's desires for her son, but recurs throughout; Alan is unable even to consider Dick Lennie's hands without imagining Dick masturbating; at this point, the narrator notes 'It was [Alan's] obsession. It was his madness. ${ }^{112}$ Alan himself seems to masturbate while thinking of Solly and 'Geoffrey'. ${ }^{113}$ Even heavy machinery becomes eroticised for him. ${ }^{114}$ The Hangover is a grubby book. However, as Copland demonstrates with his misreading of the lamp metaphor, this material is treated so obliquely that is possible to entirely miss it. The Hangover is a book that is outwardly presentable, foxing its readers while offering a minor festival of depravity.

If the novella is a work of Sargesonian critical realism, a contribution to a familiar New Zealand literature, then it is tempting to understand Alan as the bullied, bookish outsider who appears as central in many of Frame's narratives, in Maurice

\footnotetext{
${ }^{110}$ Sargeson, The Hangover 11.

${ }^{111}$ Sargeson, The Hangover 18.

${ }^{112}$ Sargeson, The Hangover 46.

${ }^{113}$ Sargeson, The Hangover 63-4.

${ }^{114}$ Sargeson, The Hangover 62.
} 
Gee's In My Father's Den, or even, in a way, in Keri Hulme's the bone people. Yet Alan's divided identity marks him apart from these figures. Identifying The Hangover as a typical instance of New Zealand literature rather than a suburban Gothic manufactures erroneous readings. This, in turn, suggests the force that genres have on the way we engage with texts.

Sargeson is writing in a mode apart from the critical realism that established his position in the literary field. He explicitly signals this, going so far as to roll in Gothic weather, or at least as close as the Auckland summer can provide, at key moments. There are grumbling thunderstorms and a 'nasty sneaking wind' when Harold Binder's daughter enters Alan's house. ${ }^{115}$ Later, when he visits the Binder house with Dick we see that
Every now and then the sky behind the fancy-coloured tiles of $\mathrm{Mr}$ Binder's brick bungalow Gothic was lit by silent flashes of lightning. It was a kind of stage-effect - designed to emphasise the outlines of a house inhabited by a monster. ${ }^{116}$

Here, Sargeson not only indicates his text's involvement in the suburban Gothic, but does it with a blunt, kitschy, directness. The Gothic is all artifice here, but a useful effect nevertheless, demarcating Binder as a monster. The irony is that Binder is hardly the worst creature the suburb holds.

Reading the novel as a Gothic, it becomes a considerably clearer piece of work, and helpfully, this brings into focus readings interested in the text as queer or national literature. In the Gothic, we expect to encounter the grotesque and the monstrous, and we are not much perturbed if this grotesquery exceeds realistic mimesis. Once we recognise that Alan is a Gothic figure, a prurient cipher rather than a realistic character, we see that, as is often the way with Gothic figures, Alan is too grotesque to be anything other than the broadest, and therefore bluntest, satire on New Zealand puritanism.

\footnotetext{
${ }^{115}$ Sargeson, The Hangover 66.

${ }^{116}$ Sargeson, The Hangover 71.
} 
Unlike the narrator of 'A Good Boy', Alan enthusiastically recapitulates the straight-laced values of his parents. He asks his mother not to blaspheme when she suggests his dead father's wishes are sacred, reminding her that only God's wishes can be so described. ${ }^{117}$ At the same time, Alan is able to apply his standards with comic selectivity. Comparing Solly, to whom he is sexually attracted, with Dick Lennie, who troubles him, and later tries to bed him, Alan reflects that

[Solly]'s the sort of person who is ripe for the redemption that depends on love. God's love. But what does Dick Lennie deserve?

- he's presented with all the advantages of life and he goes and deliberately throws them away. No love. He deserves contempt... ${ }^{118}$

Alan is careful to check his thought; Solly needs God's love - but what sort of love was Alan thinking of before he corrected himself? When Solly later defends Dick Lennie to Alan as a 'good joker... A sort of superannuated beatnik', Alan is outraged, saying that 'nothing you can say is going to stop me from hating him. He's a waster, a kind of living lie, the kind of man who deserves to be dead. ${ }^{119}$ Shortly afterward, Alan astonishingly advises Solly to 'be a Christian', while enjoying a close, potentially queer embrace with his friend. ${ }^{120}$ Alan's critique of Dick for wasting the opportunities presented him is comically deluded hypocrisy; Dick works as a janitor while Alan is looked after by his mother. Solly himself lives in a squat, sees prostitutes, and hopes to one day work for 'that Greta that gets her name in Truth'. ${ }^{121}$

Copland fumes that Alan encounters the denizens of a suburban wasteland who loll on their slacks, but really, Sargeson develops these figures in a depth that is absent from the puritan monster Alan, even though it is he who is the narrative's

\footnotetext{
${ }^{117}$ Sargeson, The Hangover 13.

${ }^{118}$ Sargeson, The Hangover 28.

${ }^{119}$ Sargeson, The Hangover 82.

${ }^{120}$ Sargeson, The Hangover 83.

${ }^{121}$ Sargeson, The Hangover 28.
} 
central character. More compelling are the figures that surround him; Dick Lennie, the aging bisexual philosopher, sexually liberated Dottie, thoroughly modern Edress, and the aspiring poet, Solly. The Hangover does not articulate a vision of 'New Zealand' as a whole so much as a tiny, nascent bohemian scene within the country, a scene that could be threatened by a certain sort of monster, the puritan gone mad. The Hangover is a horror story that presumes a savvy audience of aging beats and bohemians, queers, and young hippies. By removing the requirements of New Zealand literature from a reading of the text, we discover it is actually a much more interesting depiction of a very particular group of New Zealanders.

Citing the conviction that the young Sargeson (then still Norris Davey) received for homosexual activity, Harding frames him as 'crusader for sexualexistential freedom'. ${ }^{122}$ The difficulty is that this reading loses the complexity and danger associated with queerness in Sargeson's Gothics. In 'I've Lost my Pal', George is charming, certainly, but also a dangerous psychopath. In The Hangover, Dick Lennie, the older, wiser man who has learnt to manage his sexual identity within the confines of repressive New Zealand society is killed by the violent young homosexual who cannot. Disturbingly, it is hard to miss that Dick is a thinly disguised stand-in for the author, or that Alan's homosexuality is linked to his assault of a young girl. Sargeson's vision of queerness is paranoid, self-loathing, and performatively Gothic.

While the novella does participate in a national literature to a limited extent, The Hangover is a Gothic before it is a work of New Zealand literature. All the same, we can see the pressure of New Zealand literature as a category, practice and field working on Copland and Harding's readings. Dangerously doubled identities are common enough in Gothic texts, but are not the stuff of New Zealand literature; the country's need to produce its own literature, a need endorsed by Sargeson, becomes an impediment to understanding the text. The irony is that by reading The Hangover as a Gothic, it actually becomes a more interesting contribution to both queer and New Zealand literatures, taken in a wider sense. Although its contribution to those two areas might be lesser, it is no longer an inessential contribution to Sargeson's

\footnotetext{
${ }^{122}$ Harding, "The Oil on the Salad" 60.
} 
oeuvre, but instead, a demonstration of his range, as well as a real contribution to a New Zealand Gothic.

\section{Janet Frame's Reception and A State of Siege}

Perhaps more than any other New Zealand writer, Janet Frame has acquired an extensive personal mythology. Her famously reclusive habits exist in concert with the careful disclosures of her volumes of autobiography. She dreaded the notion of a critical biography being authored, and was upset by Patrick Evans' study, Janet Frame, complaining that her art was being read as significantly relating to her life. ${ }^{123}$ In this context, it is interesting the myth of Frame has become so heavily Gothicised. While the story of a sensitive young woman, keen on poetry but unjustly confined in a terrifying space comes directly out of Mrs Radcliffe, it is presented both in Frame's work and in Michael King's authorised biography. King gives Frame's stay at the mental hospital Seacliff, a 'building [with] the appearance of a castle out of a Gothic novel' ${ }^{124}$ a postcolonial Gothic twist:

Otago Maori... believed that the authorities had courted physical and psychic disaster by building the hospital over a tribal burial ground... According to this interpretation, the structural collapses, the fire, and the general air of terror said to prevail in wards holding the most disturbed patients were all consequences of a failure to respect ethos and the tapu [sacred restrictedness] of the location. ${ }^{125}$

In New Zealand, at least, it seems that Gothic narrative has perhaps been more strongly attached to Frame's life than her work.

\footnotetext{
${ }^{123}$ Michael King, Wrestling with the Angel: A Life of Janet Frame (Auckland: Viking, 2000) 511-2, 419; Patrick Evans, Janet Frame, Twayne's World Authors Series (Boston: Twayne Publishers, 1977).

${ }^{124}$ King, Wrestling with the Angel 72.

${ }^{125}$ King, Wrestling with the Angel 73.
} 
Despite Frame's antipathy to the blurring of her life and art, A State of Siege incorporates elements of her stay on Waiheke Island, ${ }^{126}$ and she did indeed receive a stone through her window one night, an event similar to the one that concludes the novel. ${ }^{127}$ A State of Siege tells the story of Malfred Signal, fifty-three and a spinster, a former art teacher who has recently nursed and buried her terminally ill mother. Malfred, wishing to begin her retirement in earnest, shifts from fictional Matuatangi in the South Island to Karemoana, a fictional island near Auckland, closely resembling Waiheke. Shortly after Malfred moves into her new house, she is menaced over the course of a night by an unidentified person or, perhaps, persons. Malfred projects the ghosts of her past onto the figure of the prowler. She vacillates between helpless victimhood and delirium as these shadows knock on her door, switch her electricity off, and, finally, throw a newspaper-wrapped stone through her window. On the newspaper is written the message 'Help Help'. The paper itself seems to be printed with nonsense verse. Malfred is found, three days later, dead, with the stone gripped in her hand. It is an ending to a tale of unseen threat, storm, sorrow and even madness that holds substantial ambiguities.

Mark Williams regards A State of Siege as 'Frame's major novel of the 1960s'. ${ }^{128}$ Interestingly, his sensible, lucid consideration of the book seems to be the only substantial critical reading that discusses the novel's involvement in the Gothic. The tendency amongst critics who specialise in Frame and New Zealand has been to favour readings that emphasise the psychological depth of the text, its play with language, and its relationship to place. These readings typically exclude or minimise any morbidity or grotesquery they perceive in the text.

For Judith Dell Panny, the novel is a skilfully managed allegory; she argues that it 'shows death to be a liberation from... social conventions', ${ }^{129}$ which, of course, it usually and quite obviously is. For Panny, Malfred moves from a state of bondage

\footnotetext{
${ }^{126}$ Evans, Janet Frame 53-4.

${ }^{127}$ King, Wrestling with the Angel 274-5.

${ }^{128}$ Williams, Leaving the Highway 38.

${ }^{129}$ Judith Dell Panny, I Have What I Gave: The Fiction of Janet Frame, Revised ed. (Palmerston North: Dunmore Press with Whitireia Publishing, 2002) 99-100.
} 
to a state of liberation. Panny makes a special effort to interpret the nonsense poem that wraps the rock, apparently discerning a cloud of birds that rises into the air and allows Malfred a kind of transcendence; this is Malfred's 'final act of creativity', and 'shadows are dispelled'. 130

This seems slightly strained. The problem with the nonsense poem is that it is exactly that; it is nonsense and cannot be reduced to the things Panny hopes it might be. Alex Calder, discussing the novel's use of nonsense, usefully describes nonsense as when 'the production of sense is disturbed not so much by a paucity of meaning as by an untoward abundance of possible meanings'. ${ }^{131}$ Although Calder emphasises the importance of trying to find these meanings, really, nonsense is the thing on which interpretive criticism must always founder. There are limits to interpretation. To see a flock of birds in a nonsense poem is to use literature as a Rorschach blot, privileging our response over what we have actually been presented with. Writing in general, and Frame's writing in particular, often holds qualities that manifestly are difficult, troubling, enigmatic and indeterminate. Sometimes confusion is a valid response; and certainly ambiguity has been the stock in trade of the Gothic for much of the twentieth century.

Nevertheless, Panny's attempt is largely congruent with other critical readings, which understand the narrative as a journey of self-discovery. Harding also sees the novel's narrative as a 'psychic journey... towards the acceptance of [Malfred's] meaningful self-essence and the concomitant acceptance of death' ${ }^{132}$ Gina Mercer, in addition to providing a frankly baffling reading of the novel as a 'rewriting [of] the Bible from an antipodean, female perspective', ${ }^{133}$ believes the ending can be understood as Malfred's discovery of a path towards a profoundly redemptive

\footnotetext{
${ }^{130}$ Panny 97-9.

${ }^{131}$ Alex Calder, "The Closure of Sense: Janet Frame, Language, and the Body," Antic 3 (1987): 93.

${ }^{132}$ Bruce Harding, "The Nativization of Feeling: Motifs of Bonding to the Past and to the Land in Janet Frame's $\underline{\text { A State of Siege (1966) and in The Carpathians (1988)," Journal of New Zealand Literature }}$
} 18/19 (2000/1): 123 .

${ }^{133}$ Gina Mercer, Janet Frame: Subversive Fictions (Dunedin: U of Otago P, 1994) 119. 
creativity. ${ }^{134}$ For Monique Malterre, A State of Siege is a 'quest for truth or... the story of an initiation', where Malfred attempts to 'rediscover the soul of her country'. ${ }^{135}$ Marc Delrez also characterises the novel as a 'quest'. ${ }^{136}$

Jan Cronin sees the novel as a settler narrative, ${ }^{137}$ her argument being that the story revolves around a landfall, an island, and an interest in what it means to find oneself in a new place. Harding would agree with this point, reading the novel as a parable for the 'nativization' of pakeha New Zealanders as a 'second tangata whenua' (people of the land). ${ }^{138}$

Another theme appears; we are told we ought to understand the text as primarily and profoundly positive. Some critics openly take issue with those who have suggested the novel makes dark or obscure gestures. Delrez goes so far as to apparently blame Evans for Frame's novels going out of print at one point, allegedly a result of Evans claiming that 'the atmosphere of [Frame's] work [is] almost unrelievedly dark' ${ }^{139}$ Mercer rebuffs readings of Frame as morbid by suggesting her work is wholly 'balanced' and 'merely seeks to redress the imbalance [Frame] perceives in a dominant culture which labels a whole range of topics "unacceptable" for fictional treatment'. ${ }^{140}$ In Mercer's argument, to feel that Frame is disturbing is to side with forces of oppression against the liberating power of Frame's 'subversion'.

All of these critical treatments tend to understand A State of Siege as being almost sui generis. 'If we were to play the classification game, we might say that $A$

\footnotetext{
${ }^{134}$ Mercer 115.

${ }^{135}$ Monique Malterre, "Myth and Esoterics: A Tentative Interpretation of A State of Siege," The Ring of Fire: Essays on Janet Frame, ed. Jeanne Delbaere (Sydney: Dangaroo Press, 1992) 120.
}

${ }^{136}$ Marc Delrez, "The Eye of the Storm: Vision and Survival in A State of Siege," The Ring of Fire: Essays on Janet Frame, ed. Jeanne Delbaere (Sydney: Dangaroo Press, 1992) 130.

${ }^{137}$ Jan Cronin, "'Encircling Tubes of Being': New Zealand as Hypothetical Site in Janet Frame's A State of Siege (1966)," Journal of New Zealand Literature 23.2 (2005): 79.

${ }^{138}$ Harding, "The Nativization of Feeling" 114.

${ }^{139}$ Delrez 126; P.D. Evans, "'Farthest from the Heart': The Autobiographical Parables of Janet Frame," Modern Fiction Studies 27.1 (1981): 31.

\section{${ }^{140}$ Mercer 11.}


State of Siege is a phenomenological and hermeneutical exploration' writes Cronin, ${ }^{141}$ which hardly describes a recognisable 'shape' of novel. Malterre claims it 'belongs to no definite philosophical or literary tradition'. ${ }^{142}$ For Mercer, Frame 'deliberately and successfully questions traditional fictive methods, creating new and exploratory modes'; ${ }^{143}$ Frame's work is seen as an alterity, unclassifiable. Taken together, these readings represent a significant reluctance by the New Zealand critical establishment to encounter Frame's work in general, and A State of Siege in particular, as Gothic. Of course, there are exceptions; Williams acknowledges A State of Siege as 'suburban gothic', but even for him, the Gothic elements remain an 'excess' in the novel. ${ }^{144}$

Claims for Frame's use of a wholly 'new' and nameless form are patently misguided. Her early international readers were able to classify her work with reference to familiar forms. Most often, they described her work as a literary sort of Gothic. These readers, interestingly, operated outside of the New Zealand literary field, and were not subject to the pressures that those operating within it are; there was no need to argue that Frame's writing always performed the work of New Zealand literature.

C Hartley Grattan, writing in the New York Times Book Review believed Frame was influenced by the Brontës, Faulkner and Carson McCullers, all Gothicists of varying shades, and wrote that

The theme of Owls Do Cry is simple if rather gothic. It is the study of the disintegration of a poor family, the members of which are in one way or another intellectually handicapped. The plot entails violent death, temporary insanity, suicide and consignment to

\footnotetext{
${ }^{141}$ Cronin 80.

${ }^{142}$ Malterre 124.

${ }^{143}$ Mercer 11.

${ }^{144}$ Williams, Leaving the Highway 43.
} 
institutional care. The manner is "contemporary poetic,"... and the effect is, therefore, of gilding somewhat tawdry lilies. ${ }^{145}$

Grattan explicitly labels the book a Gothic, while noting that this quality exists in tension with its aggressively modernist, consciously literary style.

Similar observations occur throughout Frame's overseas reviews. Joyce Carol Oates felt that Frame was 'obsessed with the mysteries of madness and death - but... illumination is attempted through language, not dramatic tension of one kind or another. ${ }^{, 146}$ Reviewing The Edge of the Alphabet, William Wiegand praised Frame's lyric style but saw her worldview as 'possessed... by death, madness, loneliness and pain. ${ }^{147}$ Time magazine described her as 'Writing from the focus of the spiritually down and out, the demented and the dead... Frame has developed a tidy literary reputation as a wild necromancer. ${ }^{148}$ Another Time review felt that, for Frame, 'history is a hereditary malignancy that engulfs the present and dooms the future to madness, loneliness and death. ${ }^{149}$ This is an explicitly Gothic rather than tragic view; it does not allow the positivity later critics find.

Wilfrid Sheed's review of The Adaptable Man makes comprehensive claims for Frame as a literary Gothicist:

Frame is a "witch-novelist" who stirs her plots under a full moon and has various magic powers, including a number-one witch's curse. Her prose style is a series of charms and incantations,

\footnotetext{
${ }^{145}$ C. Harley Grattan, "Tawdry Lilies," rev. of Owls Do Cry, by Janet Frame, New York Times Book Review 31 July 1960: 22.

${ }^{146}$ Joyce Carol Oates, rev. of Yellow Flowers in the Antipodean Room, by Janet Frame, New York Times Book Review 9 February 1969: 5. Given Oates' penchant for the weird, it is odd that she complains that Godfrey Rainbird's resurrection strains credulity.

${ }^{147}$ William Wiegand, "Toby, Pat and Zoe," rev. of The Edge of the Alphabet, by Janet Frame, New York Times Book Review 23 September 1962: 46.

148 "Rejected Resurrection," rev. of Yellow Flowers in the Antipodean Room, by Janet Frame, Time 21 March 1969: 105.

149 "Back to Nightmare," rev. of Intensive Care, by Janet Frame, Time 18 May 1970: 108.
} 
passwords repeated in a baleful voice, which hex up the whole landscape... Her prose is haunting, and she can use it to lay a spooky atmosphere over anything she chooses... ${ }^{150}$

Sheed's review is one of the strongest statements of a prevalent contemporary understanding of Frame; taken together, these reviews unambiguously label Frame's work as Gothic, uncanny, macabre.

International reviews of $A$ State of Siege were consistent with this view of Frame. For John Gardner, the novel is meant to frighten. He describes it as 'a lady's book, in other words, not serious fiction in the first place... An entertainment; more specifically, a psychological horror story..., ${ }^{151}$ Although Gardner's casual sexism rankles, it definitely defines the novel as a contemporary pulp Gothic. Millicent Bell more even-handedly acknowledges the novel's participation in literary and Gothic practices, but she too felt it more successful as a Gothic:

[Frame] is not, as I think she would like to be, a metaphysical poet; ideas and images do not fuse in her pages. Her style tends to dissolve into mere obscurity. Her poetic voice croons and haunts, she summons wraiths upon the dark heath, but the night passes without revelation. And yet, her fragmented visions are true nightmares, raising authentic goose-pimples on the skin. ${ }^{152}$

Bell privileges the novel's ability to provide Gothic mood and affect over its ability to provide the meaningfulness of literature.

Charles Poore would agree; his review is unsure that the novel succeeds in literary terms, but sees it as another, Gothic, turn of the screw:

\footnotetext{
${ }^{150}$ Wilfrid Sheed, "When the Spell Works It's Binding," rev. of The Adaptable Man, by Janet Frame, New York Times Book Review 8 August 1965: 4.

${ }^{151}$ John Gardner, "More Smog from the Dark Satanic Mills," rev. of A State of Siege, by Janet Frame, amongst others, The Southern Review, New Series. 5.1 (1969): 233.

${ }^{152}$ Millicent Bell, "Night-Journey of the Soul," rev. of A State of Siege, by Janet Frame, New York Times Book Review 11 September 1966: 5.
} 
[Frame] sees no reason why a person who buys a haunted house must make out with hand-me-down spooks from the last tenant. She gives her heroine specially calculated and designed spectres. Less-gifted novelists than Miss Frame should join her long leap forward. Why need they bother with démodé ghosts clanking chains, or antiquity's harridan shades howling for demon lovers? ${ }^{153}$

Although referencing Coleridge in passing, when Poore refers to lesser novelists, he seems to be comparing Frame's work to the pulp Gothics current at the time, produced by writers like Victoria Holt; this is the same assessment made by Gardner.

Today, within the context of New Zealand literary studies, the suggestion that Frame is a producer of low-to-middle-brow Gothics, even in passing, is unthinkable. Obviously, A State of Siege is very much engaged in literary practice; but it is very much a Gothic too. Sargeson's Gothics bear significant links to Poe's tales. However, if the Gothic is a part of our habitus, influences will not always be quite so clear. Genre establishes procedures that are replicated, even if the exact linkages between one text and another remain obscure. It may not have been Frame's intention, but $A$ State of Siege is essentially a reworking of Charlotte Perkins Gilman's classic weird tale, 'The Yellow Wallpaper', stretched out to novel length. ${ }^{154}$ Gilman's tale stands as a preeminent instance of the female Gothic that would become important in the seventies. Whether intentionally or not, Frame recalls the Gilman tale and predicts a strain of the wider genre that would soon come to prominence. This is typical of the way that habitus functions, allowing participants to make timely contributions to a field.

Both the Frame and the Gilman narratives centre on a woman entering into a state of seclusion. Both narrators are sensitive, and as they attempt to settle in to their new environments, this sensitivity gives way to fancy. They encounter figures that do

\footnotetext{
${ }^{153}$ Charles Poore, "The Psychedelic Power of Human Vanity," rev. of A State of Siege, by Janet Frame, New York Times 21 July 1966: 31.

${ }^{154}$ Charlotte Perkins Gilman, "The Yellow Wallpaper," American Gothic Tales, ed. Joyce Carol Oates (New York: Plume, 1996).
} 
not resolve easily into any certain form, although they attempt to interpret these forms. These figures, which are most apparent at night, contribute to their increasingly insomniac states. Both narratives conclude with the poor woman in the grip of delirium, but apparently receiving some kind of confirmation of the figure that has visited them. In the case of Gilman's narrator, she has made sense of the woman in the wallpaper by identifying with her; for Malfred, we cannot tell what the rock and its messages mean, but they form a culmination to her crisis and tangibly connect her to the prowler. In both cases, this final moment is disastrous; Gilman's narrator is left quite mad, while Malfred, although unhurt by the missile, is still found dead days later, clutching it in her hand.

As is common in the horror tale, the heroine of 'The Yellow Wallpaper' is a sketch rather than a developed representation; it is more important that she facilitate the tale's Gothic performance than represent a life on the page. In a similar manner, Oates believes Malfred 'has been created only to be acted upon by a stupid and vaguely malevolent world. ${ }^{155}$ This may be something of an overstatement; Malfred is certainly further developed than Gilman's narrator, but Oates' observation is interesting in terms of the function Malfred fulfils for the narrative. Malfred is the stage on which the haunting is performed. Much of A State of Siege is simply an examination of Malfred's psyche; however, the novel uses the Gothic as an organisational device, signalling what is to come in the narrative, and motivating Malfred's largely inward considerations.

The locals are mysteriously horrified to learn that Malfred is moving into the house, and she is encouraged to lock her door on account of an 'element' on Karemoana. ${ }^{156}$ She attempts to have the telephone put on at the house, emphasising her especial need to the operator in terms of her isolation and vulnerability; 'a retired woman, living by herself' on an island where there is this 'element'. ${ }^{157}$ The narrative attention paid to an otherwise banal task, and the weighting of the possible danger of not having a phone signal that Malfred will become a victim of this element.

\footnotetext{
${ }^{155}$ Oates, rev. of Yellow Flowers in the Antipodean Room 5.

${ }^{156}$ Janet Frame, A State of Siege, 1966, A State of Siege and the Rainbirds, The Janet Frame Collection (Auckland: Vintage, 2006) 59, 64.

${ }^{157}$ Frame, A State of Siege 77.
} 
Williams' disarmingly simple assessment, that Frame is always a "“a good read" as well as being demanding and difficult', ${ }^{158}$ seems significant here. Frame makes a text many critics see as a complex literary performance read like a Gothic thriller.

One of Malfred's principal goals in retiring to Karemoana is to develop a 'New View', an authentic way of seeing that will inform her art. To do so, Malfred examines her self, the 'room two inches behind the eyes'. ${ }^{159}$ This is an examination that has as much in common with the psychotherapeutic process as it does with Malfred's ambitions for her artistic production. This New View will take Malfred beyond the insipid watercolours she has previously painted, and requires her to see the 'strangeness' of things. ${ }^{160}$ Early in the text we gain a sense of what this might mean. On disembarking from the ferry, Malfred observes her fellow passengers:

[S]he relaxed, sat on her suitcase, deliberately apart from the crowd, and painted in her mind her New View of them. It was not flattering. Their hands were hooks. Some had gashed faces. All stood against a background of squares and rectangles of goldenbrown and white light. ${ }^{161}$

The background provided by Malfred's New View seems to draw on the contemporary fashion for abstract expressionism, but her figures are grotesque, both violent and wounded. She transforms the jostling crowd into something weird and inhuman. In Malfred's aesthetic, modernism converges with the Gothic. This is an important combination for A State of Siege. The novel is composed almost entirely of Malfred's perceptions, and she is consciously pushing them into this new and grotesque way of seeing the world. In a minor way, by directing her imagination towards the bold and the weird rather than the palely water-coloured world of mere

\footnotetext{
${ }^{158}$ Williams, Leaving the Highway 42.

${ }^{159}$ Frame, A State of Siege 36-7.

${ }^{160}$ Frame, A State of Siege 46.

${ }^{161}$ Frame, A State of Siege 49.
} 
representation, Malfred is practising the Gothic. What is being represented is less important than Malfred's sinister revision of it.

It is Malfred's urge to develop a New View, her artistic bent, which sets her apart from the social world as much as her physical isolation on Karemoana. In this way, she is a little like Sargeson's George and Victor, and Poe's Usher; too sensitive, troubled by perceptions and feelings that others do not experience. She recalls her disappointment with her students back in Matuatangi; on asking them to paint or draw a scene in an air raid shelter, Malfred is discontented by the cheerfulness of the resulting artworks. She wistfully wishes that she could have injected her students with horror, 'as a hunter now gives an injection of stimulant or tranquilliser to the beasts in his charge.' ${ }^{162}$ Malfred sees her students as lacking empathy and aesthetic capacity; her complaint will be familiar to readers of 'Fretful Sleepers', which characterises the majority of New Zealanders as small-minded and catastrophically uncultured and insensitive. ${ }^{163}$ However, Malfred's desire to 'inject' her young charges with horror remains a Gothic one. Rather than wanting her charges to learn empathy, Malfred's peculiar choice of simile suggests that she needs to appal them, and that it is more important to her that they feel this horror than understand why they feel it. Malfred has become quietly alienated to the extent that, although she has not acted on this urge, she would rather shock than teach. Malfred's worldview culminates in her New View, and as modern as it might sound, it is a particularly Gothic strain of modernism.

Malfred's quest for this New View has motivated her journey to Karemoana, and her decision to purchase her new house was determined by 'the view alone. The View. The View. Another God to worship. People on a hill, the panoramic people. Panoramania. ${ }^{, 164}$ Malfred at once slyly observes the enormous value we place on scenic vistas and acknowledges their spectacular power, even if this acknowledgement is touched with irony. The house itself is a part of Malfred's New View, and as the night wears on, Malfred's location meshes with her way of seeing, so that place and perception become the same thing. In this context, it seems that the

\footnotetext{
${ }^{162}$ Frame, A State of Siege 86.

${ }^{163}$ Pearson.

${ }^{164}$ Frame, A State of Siege 108.
} 
New View is potentially dangerous; a woman uncannily like Malfred has died in the house just before she took it.

Her New View's tendency to see the world as grotesque and dangerous alters the landscapes Malfred inhabits. A muggy spring morning in Auckland is observed as 'a still day, with the sky full of clouds and the air strangely warm, as if suffering from a low fever', a place where even scaffolding has 'a more sinister meaning'. ${ }^{165}$ Karemoana may well be introduced as a 'South Pacific paradise', ${ }^{166}$ but it is also a threatening place, even though this threat is sometimes articulated in comic terms. Karemoana is where

the only enemies of man, apart from man, were wasps as big as flying tigers, a few mosquitoes breeding a giant island strain... and perhaps, though one does not explain why, the sullen grey mangroves standing in their beds of mud in the tidal inlets facing the mainland. ${ }^{167}$

Our attention is directed to the supposed size of island insects, couched in the conversational, jokey terms common amongst beachside communities in New Zealand; is there anywhere where the insects are not supposed to be the most pernicious imaginable? Yet the real threat of malign human agency is also mentioned, a threat almost swallowed by the vividness of the insect menace. Credible threats are married to common nuisances; both are real enough. However, something stranger is then presented; the threat of the landscape itself.

The mangroves are described in terms that still suggest comic dread. We presume Malfred does not explain why the mangroves are threatening for fear she might seem a little batty. However, the mangroves recur throughout the text, until Malfred admits she is 'haunted' by them and feels she must paint them, a suitable subject to exercise her New View. Poor children play (and play dead) amongst the trees, their poverty obscurely linked to the mangrove swamp; Malfred describes it as a

\footnotetext{
${ }^{165}$ Frame, A State of Siege 52.

${ }^{166}$ Frame, A State of Siege 31.

${ }^{167}$ Frame, A State of Siege 31.
} 
sordid, calm, sinister bed of grey mud... sinister evidence of a drowned miniature forest... the [nearby] holiday baches had a derelict appearance that seemed not to be the result of their winter desertion but of their nearness to the mangrove swamp... the mangroves... had the power to lure poverty as a kind of human accompaniment to their own vegetable squalor. ${ }^{168}$

Malfred eventually sees the island as a place where 'wild cats... vanish with a witchlike scream into the manuka scrub'. ${ }^{169}$ She imagines the place abandoned and overgrown, 'the small holiday baches... deserted forever, the gorse, the white manuka, golden ice-plant growing up through their decayed floors, with black mould spotted on the faded cretonne curtains... ${ }^{170}$ Whatever desolating power Karemoana has, or Malfred imagines it to have, is no longer confined to the mangroves.

Over the course of Malfred's nocturnal ordeal, a storm rages outside, in the best Gothic fashion. Finally, when the wrapped brick enters the house, so too does the storm:

The wind, waiting at the window, leapt through the ragged gap, flapping wildly at the curtains; and, in a moment, the storm had entered the room, the wind was whistling through the house, all the curtains were dancing wildly. The house grew cold... A sense of collapse seemed to overcome the house, as if its walls were made of paper. ${ }^{171}$

There has been a critical effort to understand the nonsense verse printed on the newspaper, a text that must be Malfred's invention. Perhaps more significant, and

\footnotetext{
${ }^{168}$ Frame, A State of Siege $80-1$.

${ }^{169}$ Frame, A State of Siege 164.

${ }^{170}$ Frame, A State of Siege 165.

${ }^{171}$ Frame, A State of Siege 242-3.
} 
certainly more meaningful, is the shattering of the window, and the entry of the wind. A view has been broken open, but whether this represents an old view discarded or a new one foundering, we cannot say. The entry of the wind into the house brings with it the increasingly Gothic aspect of Karemoana; the weather carries the malevolent agency of the mangroves, the unkindness of the prowler. The 'element' is made literal here as the elements enter the house.

However, Frame playfully nests another layer, another order of meaning in this passage. A State of Siege takes a metafictional turn; the walls of Malfred's house are made of paper in that they exist as they are described to us on the pages of the book. The text itself is about to collapse; in a narrative sense, the story is about to end abruptly. What remains of the text is the nonsense of the newsprint, and the few words of an external narrator, informing us of Malfred's death. Malfred herself collapses. We do not know why she dies, but die she does. It is difficult to tell exactly what has happened, but it is certainly some kind of personal disaster. Despite the insistence of the bulk of Frame's critics to the contrary, the entry of the element into Malfred's bach is a Gothic conclusion; a fall like Usher's more than a moment of selfknowledge or liberation.

A State of Siege's denouement is puzzling, but understood as a Gothic, legible. As with 'The Turn of the Screw', we cannot account for what, exactly, has happened, let alone exactly what we ought to make of it. Yet while the particulars of the ending are unclear, the shape of the narrative is familiar. In the James, we cannot tell why Miles dies; in 'Usher' we cannot tell why the house itself falls into the murky tarn. We accept the unresolved nature of A State of Siege's ending because, although ambiguous, it feels right; the Gothic has been performed, and has led us to the point of collapse it so often does. The novel relies on its reader's Gothic habitus to render the text complete and satisfying as a reading experience.

Recognising A State of Siege's participation in the Gothic provides a necessary counterweight to more literary, highly interpreted views of the novel. Most of Frame's critics from within the New Zealand field have required her oeuvre to work towards the creation of a New Zealand literature, which, in its received version, ought to be socially engaged, offer political critique, negotiate postcolonial anxieties, and so forth. The critical revaluation of the Gothic that has occurred through the emergence of Gothic studies suggests that Gothic texts are capable of entering into exactly these sorts of discourse. However, this thesis argues that these discursive elements are 
incidental rather than essential to the Gothic. Nevertheless, this does not preclude texts from being involved in both practices. In addition to all its patently literary turns, its clever observation and language, when A State of Siege offers the howls of wild cats, the malignant presence of the mangroves and baches turned to ruin, ghosts from Malfred's past and an endless rapping noise, it is practising a possible New Zealand Gothic. Frame shows us, just as Sargeson does, how the Gothic might be performed in the New Zealand context.

\section{Conclusion: Gothic Landscapes and Antipodean Tales}

An examination of the New Zealand Gothic raises the wider question of how we are to understand national Gothics. One of the hallmarks of the Gothic is that it is readily identifiable as such; common readers can identify a text as Gothic, even if they do not use the epithet. While it seems reasonable to understand the texts discussed in this chapter as Gothic, they have, if at all, only occasionally been understood in this way. The most difficult thing about the New Zealand Gothic is that unlike other national Gothics, it does not have this obviousness, and despite the suggestions made in this chapter, remains a tentative proposition. Categories like the American or British Gothic are self-evident. The New Zealand Gothic is not only difficult for readers to describe, but retains a degree of critical incoherence too.

Often, national Gothics are accounted for by critical suggestions that they arise as a consequence of sundry historical anxieties and pressures; this thesis has resisted those accounts. New Zealand has had no shortage of historic crises, but it has not yet produced a coherent, fully formed Gothic practice. Indeed, it seems likely that the vast majority of Gothics consumed within New Zealand are imports. The procedures of the English and American Gothic are popularly familiar in New Zealand in a way that a native Gothic is not.

Antipodean Tales, published in 1996, is the only collection of short fiction that has consciously attempted to develop a New Zealand Gothic. It also illustrates many of the uncertainties surrounding a local Gothic. Editor Stephen Cain makes a blunt assessment of the national literary field in his introduction: 
the absence of local varieties [of Gothic fiction] on our bookshelves becomes an indictment of the stranglehold which the peculiar bias towards academic writing in New Zealand has placed on local creativity. Perhaps it is too much to hope that one slim volume can breathe life into the idea (not much subscribed to locally) that writing for readers rather than for Arts Council money has virtue. I do hope, however, that this collection will show that quality need not be sacrificed in our reckless headlong flight from the terminally dull. ${ }^{172}$

Oddly, Cain's bitter analysis is not dissimilar to my argument that the Gothic and literature are distinct practices, although Cain seems to believe that the one practice suppresses the other. Cain sees New Zealand literature as a stifling monolith, a Bourdieuvian field sanctioned and funded by the state that it is virtually unassailable. While this analysis is somewhat careless, it is also suggestive of the power of the New Zealand literary field, at least during the nineties. A certain understanding of New Zealand literature was being promoted, and Cain sees this as excluding groups of writers and even entire readerships. This chapter has suggested it certainly excluded particular readings of canonical texts.

Appropriately, given Cain's insistence that the New Zealand Gothic exists outside of the literary field, Antipodean Tales was published by a house not recognised for its publication of fiction, and collects tales from largely unknown authors. The Evening Post's reviewer wondered if the stories included 'strictly meet the description "Gothic" - whatever that covers', and noted that 'there is a distinct "Kiwi" feel to only a few of the stories. While not in itself any sort of drawback, it perhaps highlights... the lack of writers tackling indigenous trips to the dark side of the track'. ${ }^{173}$ In other words, the reviewer is uncertain about exactly what the New Zealand Gothic might entail; this is an uncertainty played out in the collection itself.

\footnotetext{
${ }^{172}$ Stephen Cain, Introduction, Antipodean Tales: Stories from the Dark Side, ed. Stephen Cain (Wellington: IPL Books, 1996) 6.

${ }^{173}$ Steve Rendle, "Entertaining Trip to the Dark Side," rev. of Antipodean Tales: Stories from the Dark

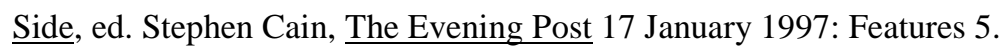


Although about three quarters of the stories in the collection feature some kind of link to New Zealand, often that link is marginal, or does not absolutely locate the story in New Zealand. Of the tales that do rely on a New Zealand setting, most seem somewhat awkward. This is unsurprising, given the still early state of the local genre. Stories encounter problems that do not trouble other national traditions. For instance, 'Never Go Tramping Alone' is the story of a Michael Bassett (seemingly no relation to the well-known New Zealand ex-cabinet minister and academic) who, having argued with his wife, goes tramping in the Ruahine Ranges. He comes across a hut, and is lured inside by a seductive woman who feeds him a stew that seems suspiciously like human flesh. No less than five lone trampers have recently disappeared; the woman transforms into a monster called a Gravatt, which kills him, although his subjectivity persists within it. The twist ending has Michael's estranged wife entering the hut; Michael and the monster will kill her. ${ }^{174}$

The Gravatt is an unusual construction. The monster's appearance (hairy, neckless, red-eyed) is explained in detail, as is the process by which it feeds on 'energy', ${ }^{175}$ but this does not account for the Gravatt itself. Why does it reside in the Ruahines, and why does it require anthropophagy? When we encounter the wendigo, a not dissimilar spirit to the Gravatt, in Ann Tracy's Winter Hunger or Stephen King's Pet Sematary, we have a vague sense that such beings 'exist' and belong in the American or Canadian landscapes in which they are located. A Gravatt, however, has no such precedent, no such sense of belonging, and thus loses its authority. While the Gothic celebrates the bizarre, it would be a mistake to think that it does not make sense; and 'Never Go Tramping Alone' does not make sense in the way the Gothic ought.

A different, although related, problem emerges in 'Collecting'. ${ }^{176}$ Cath Thomson, a young researcher specialising in pre-European Maori, visits London, and calls on Mr Wellcom, a butcher, who she has been told by her 'Prof' is in possession

\footnotetext{
${ }^{174}$ Alyson Creswell Moorcock, "Never Go Tramping Alone," Antipodean Tales: Stories from the Dark

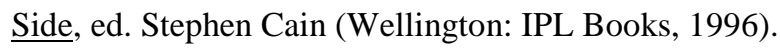

${ }^{175}$ Creswell Moorcock 67, 70 .

${ }^{176}$ Rosemary Britten, "Collecting," Antipodean Tales: Stories from the Dark Side, ed. Stephen Cain (Wellington: IPL Books, 1996).
} 
of an interesting collection. He leads her to a room above his shop; it is filled with his grandfather's collection of forty-nine mokomokai or upoko tuhi (preserved Maori heads). The story concludes as he expresses a desire to manufacture a fiftieth head, and locks Cath in the room. Although the tale is not set in New Zealand, it describes a horror that has a special connection to New Zealand and especially Maori culture; yet its depiction is spectacularly maladroit.

Cath is Maori, and a specialist in Maori studies, but describes the upoko tuhi not by their proper name, but instead as 'preserved heads' ${ }^{177}$ Her reaction is one of morbid fascination rather than a recognition of the massive violation of tikanga Maori that the collection represents. Gothic readers will happily suspend certain sorts of disbelief; but this is a complete failure of mimesis.

Taken together, 'Never Go Tramping Alone' and 'Collecting' suggest some of the difficulties that a formational national Gothic presents. The Gravatt of 'Never Go Tramping Alone' fails to 'naturally' interface with the landscape it resides within. 'Collecting', on the other hand, does not acknowledge the significance of upoko tuhi to New Zealand culture in general and Maori culture in particular; the horror loses credibility because Cath's reaction does not make sense. These may be performances of the Gothic, but they do not sit comfortably within the scope of New Zealand culture. A successful national Gothic requires both criteria to be fulfilled. Most New Zealand readers, who, unsurprisingly, form the primary audience for a New Zealand Gothic, will be unable to find these stories' ingredients sufficiently 'natural' to pass; they become uncomfortable arrangements. Similar problems emerge in other Antipodean Tales such as 'The House' and 'Turehu', ${ }^{178}$ both of which feature mishandled engagements with Maori culture.

Academic renderings of the New Zealand Gothic sometimes suggest it might be an expression of settler unease or postcolonial guilt. Antipodean Tales apparently needs to be involved with Maori culture, no matter how crudely. The collection cannot be understood as trying to create a genuinely bicultural Gothic, but instead seems to be trying to address a perceived lack. National Gothics come with histories

\footnotetext{
${ }^{177}$ Britten 136.

${ }^{178}$ Oliver Nicks, "The House"; Laurie Mantell, "Turehu"; both in Antipodean Tales: Stories from the Dark Side, ed. Stephen Cain (Wellington: IPL Books, 1996).
} 
and canons, and this is what the New Zealand Gothic is missing. The Gothic tales mentioned in Maoriland, where Maori provide a useful although now politically unacceptable resource for the Gothic's horrors, have been popularly forgotten, yet the writers of Antipodean Tales apparently feel the need to recreate these sorts of tales, no matter how incompetently. Gothic habitus expects to find these narratives, and in their apparent absence, creates them.

The stories in Antipodean Tales simply do not sit comfortably, 'naturally' within a New Zealand context. How, then, ought the Gothic to be performed in New Zealand? How does the genre relate to place?

The Gothic is a negotiation between what is presented to a reader and what that reader senses and knows about the Gothic. Some landscapes hold properties that encourage us to understand and engage with them as Gothic, while others are less likely to encourage this. The Gothic, a practice, is adaptable but largely pragmatic. In the absence of suitable castles in New Zealand, it will look for other locales in which to stage its performances, but this is not to deploy a substitute so much as an alternate. The habitus refers to precedent, but improvises too. A haunted castle is not replaced by, for instance, a ruined bach, but a ruined bach nevertheless may be useful to Gothic narrative. This appropriation is motivated by a Gothic preference for architectural decrepitude, but also simply because the bach is locally available. However, it is only through the repetition of practice over time that these new alternates come to hold the self-evident quality, the useful cliché, of the haunted castle.

In the context of ethnographic fieldwork, Michael Jackson discusses the practice of 'storying' a landscape, where those who live within it attach narratives of myth and more recent history to its geography. ${ }^{179}$ This creates a sense of embeddedness, arranging the way that people relate to place. Thus, although Jackson would resist a term so precise, habitus, a people's common sense, rests in part on a relationship with the landscape, and with groups of narratives.

Although a separate process, the creation of a national literature is, in at least one way, analogous; it involves placing story within a landscape, or more exactly, a set of landscapes that together form a nation. In concert with history, national literatures story a landscape too. Yet literature does not necessarily locate story as specifically as history and cartography; its storied landscape can be more general in

\footnotetext{
${ }^{179}$ Michael Jackson, Minima Ethnographica: Intersubjectivity and the Anthropological Project (Chicago and London: The U of Chicago P, 1998) 175-81.
} 
scope. For instance, when we read about the bush, or the beach, this could describe any number of discrete locations, and thus, story potentially leaks into all of these locations.

Because storying is a geographic process, and not every story can occupy the same space, part of the process of storying is finding the right place for the right story. This is how genre, which amongst other things describes a type of story, relates to landscape. Returning to the subjunctive worlds discussed in chapter three, these storied sites become reminders of the subjunctive 'as if', a place where it is as if something particular might happen, even if we accept that, in reality, it probably will not.

Fully developed national Gothics bring with them a landscape that holds Gothic story. For instance, in the context of the American Gothic, Ray Bradbury suggests an 'October Country':

... that country where it is always turning late in the year. That country where the hills are fog and the rivers are mist; where noons go quickly, dusks and twilights linger, and midnights stay. That country composed in the main of cellars, sub-cellars, coal-bins, closets, attics, and pantries faced away from the sun. That country whose people are autumn people, thinking only autumn thoughts. Whose people passing at night on the empty walks sound like rain... ${ }^{180}$

This passage suggests the way that the American Gothic is inlaid in landscape. The terrain Bradbury details is where Gothic narrative ought to be located, and his description has a 'rightness' missing from many of the attempts made in Antipodean Tales. Yet, although Bradbury's October Country naturally seems to be Gothic, of course, no landscape or environment, in itself, is Gothic; the Gothic, more than a creation of culture, is also the action of culture. Developed national Gothics are resources that allow readers and writers to sense how a landscape ought to 'be Gothic'; the Gothic confection comes to seem entirely natural.

\footnotetext{
${ }^{180}$ Ray Bradbury, The October Country (London: Simon \& Schuster, 1998) n.pag. Ellipses in original.
} 
The apparent naturalness of storied landscape emerges through use and repetition. New Zealand literature has engaged with this process, but as I have suggested above, as is doubtless the case with all national literatures, it tends to promote certain sorts of stories, while excluding others. The New Zealand tradition, and especially the critical discourse that surrounds it, has paid little attention to the Gothic, and consequently, the practice does not yet have a strong relationship with the New Zealand landscape.

This has not prevented a small but significant number of texts by canonical authors engaging with Gothic practice. Both Sargeson and Frame successfully present a darkened New Zealand landscape, contributing to its Gothic storying, but Gothic procedures are not so firmly established in New Zealand that less able writers are easily able to reproduce convincing New Zealand Gothics. Nevertheless, Frame and Sargeson's texts indicate where we might begin to locate the New Zealand Gothic.

Where other nations have a substantial Gothic field and storied landscapes that enable and regulate the practice of the Gothic, New Zealand's field is only beginning to cohere; that Cain's Antipodean Tales are often tentative or inept signals its early stage of development. However, what the collection misses, in common with the bulk of extant criticism, is that some texts primarily regarded as New Zealand literature might equally or better be regarded as Gothics; prior, in some cases, to their classification as New Zealand literature. It is not that a New Zealand Gothic has not been authored, but rather that texts which might contribute to the field have not been satisfactorily identified as such, have not formed a useful canon, and are not strongly tied to the landscape itself.

This chapter suggests that sometimes Frame and Sargeson were indeed creating what has come to be accepted as New Zealand literature, but that sometimes it is more useful to understand their work as performing the Gothic before it addresses national discourses. Malfred Signal's decline and death is not Frame's most incisive analysis of New Zealand society; Sargeson's murderous men are entertainments before they are accurate representations of New Zealand masculinity.

The New Zealand Gothic is not yet a settled popular practice; the texts of Maoriland remain abandoned outside of specialist scholarship, meaning that those earlier Gothics remain unrecognised. More generally, the relationship of popular genres to New Zealand literature remains an uneasy one. It is not as Wevers claims, that the New Zealand Gothic barely exists, or as Lawn would have it, that it is 
everywhere, hiding in the shadows; ${ }^{181}$ instead, it is still being worked out, and is often simply misrecognised.

While there is a renewed interest in articulating a New Zealand Gothic, it will take years yet of publication, teaching and popular discourse, as well as the ongoing creation of Gothic texts, to establish how various Gothic manifestations ought to work in a New Zealand context, to inlay the Gothic confidently in the New Zealand milieu, and to agree upon a body of texts that satisfactorily perform the New Zealand Gothic, forming its canon, shaping the field.

${ }^{181}$ Wevers, "The Politics of Culture" 116; Lawn, "Warping the Familiar" 11-21. 


\section{CONCLUSION:}

\section{The Gothic as Practice}

If the Gothic can be understood as a distinct practice, there are substantial implications for how we should approach the genre and its texts.

While readings of Gothic texts that emphasise direct historicity, psychic crises and political complexities are sometimes valid, on other occasions, they do not reflect the act of reading as it is experienced by the Gothic's audience. We require a methodology that recognises the ways in which popular genres, and especially the Gothic, produce different sorts of texts, and understands these texts within the context of the practical procedures and distinct fields that accompany them.

This thesis has argued that different genres can be distinguished by their characteristic practices, and has described the Gothic through Bourdieu's explication of habitus. Readers engage with Gothic texts for distinct ends, and in distinct ways. The 'fuzziness' of habitus reminds us that the genre remains elusive when we analyse it - because it is a discrete practice, the Gothic is irreducible. At the same time, it is a historicised cultural phenomenon and cannot be constructed through argument. While the Gothic is transposable, it maintains a 'correctness' that excludes instances like Martha Stewart. For readers, the genre seems to be essential in nature, even though it is constructed; the genre seems to possess what might be colloquially described as a 'vibe'.

'Gothic habitus' generates practical action; its mode of logic tends to common sense, and is predisposed to produce the regular. When common readers identify a text as Gothic, they engage with it in a particular way. The Gothic text exists within a particular horizon of expectations, and this field is the proper context in which to read the Gothic. This recognition engenders a kind of perceptual shift. Gothic habitus enables readers to negotiate the implicit emphases of the text; Gothics are read with a set of expectations and procedures in mind. Although the Gothic is a repetitive genre, readers tend to note the 'originality' of texts; when readers natively understand a genre, they look forward to its familiar pleasures while enjoying the distinguishing features of a particular text, the novelty of its performance of the genre. It is less useful to look for what the Gothic text 'means' than to see it as providing an individual modulation of a specific kind of reading experience. 
Literary and Gothic practices, of course, often happily co-exist in a single text, but need to be carefully arranged so that they work in concert, as in texts like Beloved rather than against each other, as in Mysteries of Winterthurn. However, many texts, especially popular Gothics, have very little to do with literary practice at all, but remain compelling genre performances, as evidenced by tales like Stephen King's 'The Raft'.

If the Gothic is not primarily a discursive practice, neither is it simply affective. It does not exist simply to represent or cause fear; it is often revolting, or melancholy, or funny, or appealing, and can hold properties that might suggest any number of responses, alone or in combination. Yet these are only elements of a larger imaginative experience, a familiar game of make-believe that we play with Gothic texts. The exact functioning of this game changes as the field itself changes through history. The Gothic offers us similar, although non-identical, pleasures every time we engage with it, very occasionally throwing out something genuinely new.

This game of make believe is generated from a familiar palette, on which is blended trope, narrative procedure, ways of thinking, affect, and even sensations, or at least their fictional equivalents. This is the Gothic's distinct subjunctive, where it is as if these are truths about, and genuine representations of, a world. The Gothic is interested in silence, and screams. If the wind blows, it may as well howl, although not so loud as to completely mask the mysterious dripping sound beneath it. It is about literal as much as metaphoric darkness; what light there is comes from the moon, or a stuttering torch, or a failing candle. We talk about the confounding ambiguities of the genre, but really, this is just a theorised way of saying that we cannot see what it is being represented - the Gothic's ambiguity is often much the same as straining our eyes against the dark. Practice becomes a familiar mode of subjunctive subjectivity, an experience of the 'vibe' suggested above. The act of reading the Gothic can be likened to ritual. It is a repetition, insincere, performative and potentially immersive. Participation is significant before it is meaningful, per se.

By examining three fields in turn, we can see that each has its own distinctive texture. The American Gothic of the mid-eighties was marked by largeness of theme and of text. On the one hand, the popular horror blockbuster was dominant; on the other, literary writers were co-opting the genre, and attempting to deploy it in ways that were loosely congruent with the academy's new claims for the genre, with varying degrees of success. In this, we can see how academic discourse sometimes 
coexists with a popular practice; however, while this might have been a distinctive characteristic of some American iterations of the practice, it hardly constitutes a permanent revision of the genre. As important as Beloved is, few Gothics have imitated it, suggesting that its impact has been much larger within the academy and the literary field than it has been on the Gothic itself.

The English Gothic of the nineteen-sixties is a field in a 'classical' period, where, often, there is a substantial degree of likeness between texts. Nevertheless, despite their apparent similarities, texts define themselves against each other; no matter how many times we encounter the same thing, as in the case of the black mass, the Gothic text attempts to provide a sufficiently novel performance of the practice. This might involve an appeal to different readerships through involvements in other genres; The Devil on Lammas Night, which offers the pleasures of the paperback romance, is likely to appeal to a slightly different audience to that of The Devil Rides Out. The Gothic refers to its immediate field as much or more than it does historical manifestations of the genre. Likewise, its performance will be informed as much by the state of the field as it is by the pressures of the contemporary real.

That the Gothic is a popular practice is confirmed by the confusions attendant on the New Zealand Gothic. It is the long work of history and practice that make it come to seem that stories 'naturally' relate to a particular landscape. Critics alone cannot usefully define the practice; the Gothic cannot simply be declared. At the same time, the New Zealand situation, where nationalistic literary practice has directed attention away from the role of genre, reminds us that criticism does have power, and that misreading is the predictable result of an insistence that Gothics are essentially no different from the body of literature. Nevertheless, canonical New Zealand literature has undoubtedly been involved with the genre, and a sensible understanding of the New Zealand Gothic will emerge as the New Zealand field opens itself to the notion of genre.

Considering these three fields alongside one another also emphasises just how different they are. Discussions of the genre need to be carefully historicised. The orientation of individual texts within their field ought to be considered; but also the orientation of one part of the field to another within the wider Gothic field. For instance, we note the New Zealand Gothic has little to do with Walpole. Indeed, Frame and Sargeson's texts of the sixties have little in common with the concurrent English Gothic of Wheatley and his followers. While the principles of the practices 
that operate within these disparate texts are not dissimilar, there are substantial distances between the texts themselves. Placing these three moments from the twentieth century Gothic next to one another reminds us of the Gothic's mutability. Today, we are beset by vampires, but for a brief period, the black mass was just as important to the genre.

Critical approaches to the Gothic need to carefully survey the field they treat to ensure they identify those elements of wider Gothic practice that are most relevant at any given point. This is an act of historicisation, but a historicisation that refers to the Gothic field before it refers to the historic real. The Gothic is a particular cultural strand, a discrete and recognisable phenomenon. The genre is endlessly repeated yet perpetually transforming, an imaginative cultural practice grounded in the canniness of habitus. 


\section{WORKS CITED}

Aickman, Robert. "Bind Your Hair." Dark Entries. London: Collins, 1964. 145-73.

---, ed. The Fontana Book of Great Ghost Stories. London: Fontana, 1964.

---. Powers of Darkness. London: Collins, 1966.

---. "Ringing the Changes." Dark Entries. London: Collins, 1964. 34-65.

---, ed. The Third Fontana Book of Great Ghost Stories. London: Fontana, 1966.

Amis, Kingsley. The Green Man. London: Jonathan Cape, 1969.

---. New Maps of Hell. 1960. London: New English Library, 1969.

Anderson, Benedict. Imagined Communities: Reflections on the Origin and Spread of Nationalism. Revised ed. London: Verso, 1991.

Atwood, Margaret. Rev. of Beloved, by Toni Morrison. 1987. Toni Morrison: Critical Perspectives Past and Present. Eds. Henry Louis Gates Jr. and K. A. Appiah. Amistad Literary Series. New York: Amistad, 1993. 32-5.

Austen, Jane. Northanger Abbey. 1818. Ed. Marilyn Butler. London: Penguin, 2003.

"Back to Nightmare," Rev. of Intensive Care, by Janet Frame. Time 18 May 1970: 108.

Badley, Linda. "The Sin Eater: Orality, Postliteracy, and the Early Stephen King." Stephen King. Ed. Harold Bloom. Bloom's Modern Critical Views. New York: Chelsea House, 2007. 95-123.

Bakhtin, Mikhail. Rabelais and His World. Trans. Hélène Iswolsky. Bloomington: Indiana University Press, 1984.

Baldick, Chris, and Robert Mighall. "Gothic Criticism." A Companion to the Gothic. Ed. David Punter. Blackwell Companions to Literature and Culture. Oxford: Blackwell, 2000. 209-28.

Batchelor, John. Mervyn Peake: A Biographical and Critical Exploration. London: Duckworth, 1974.

Baxter, James K. "The Dark Side." Collected Poems. Ed. J.E. Weir. Wellington: Oxford University Press, 1979. 117-8.

---. "Pig Island Letters." Collected Poems. Ed. J.E. Weir. Wellington: Oxford University Press, 1979. 276-85.

---. "Sestina of the Makutu." Collected Poems. Ed. J.E. Weir. Wellington: Oxford University Press, 1979. 590-1.

---. "The Woman on the Stair." Collected Poems. Ed. J.E. Weir. Wellington: Oxford University Press, 1979. 155-6.

Bayer-Berenbaum, Linda. The Gothic Imagination: Expansion in Gothic Literature and Art. Rutherford, NJ: Fairleigh Dickinson University Press, 1982.

Bell, Millicent. "Night-Journey of the Soul." Rev. of A State of Siege, by Janet Frame. New York Times Book Review 11 September 1966: 5. 
Benefiel, Candace R. "Blood Relations: The Gothic Perversion of the Nuclear Family in Anne Rice's Interview with the Vampire." The Journal of Popular Culture 38.2 (2004): 261-74.

Birkhead, Edith. The Tale of Terror: A Study of the Gothic Romance. London: Constable, 1921.

Blake, William. "And did those feet in ancient time." William Blake: A Selection of Poems and Letters. Ed. J. Bronowski. Harmondsworth: Penguin, 195: 162.

Bloch, Robert. "How to Write Horribly for Fun and Profit." Introduction. How to Write Tales of Horror, Fantasy \& Science Fiction. 1987. Ed. J.N. Williamson. London: Robinson, 1990. 7-10.

Bloom, Clive. Bestsellers: Popular Fiction since 1900. Basingstoke: Palgrave Macmillan, 2002.

Bloom, Harold. Introduction. Stephen King. Updated ed. Ed. Harold Bloom. Bloom's Modern Critical Views. New York: Chelsea House, 2007. 1-3.

Bondanella, Peter. Umberto Eco and the Open Text: Semiotics, Fiction, Popular Culture. Cambridge: Cambridge University Press, 1997.

Botting, Fred. "The Gothic Production of the Unconscious." Spectral Readings: Towards a Gothic Geography. Eds. Glennis Byron and David Punter. Basingstoke: Palgrave Macmillan, 1999. 11-36.

---. "The Gothic." Preface. The Gothic. Ed. Fred Botting. Essays and Studies 54. Cambridge: D.S. Brewer, 2001. 1-6.

Bourdieu, Pierre. Distinction: A Social Critique of the Judgement of Taste. Trans. Richard Nice. Massachusetts: Harvard University Press, 1984.

---. "Field of Power, Literary Field and Habitus." Trans. Claud DuVerlie. The Field of Cultural Production: Essays on Art and Literature. Ed. Randal Johnson. New York: Columbia University Press, 1993. 161-75.

---. The Logic of Practice. Trans. Richard Nice. Stanford: Stanford University Press, 1990.

---. "Outline of a Sociological Theory of Art Perception." The Field of Cultural Production: Essays on Art and Literature. Ed. Randal Johnson. New York: Columbia University Press, 1993. 215-37.

---. "Principles for a Sociology of Cultural Works." Trans. Priscilla Parkhurst Ferguson. The Field of Cultural Production: Essays on Art and Literature. Ed. Randal Johnson. New York: Columbia University Press, 1993. 176-91.

Bourdieu, Pierre, and Loïc J.D. Wacquant. An Invitation to Reflexive Sociology. Chicago: University of Chicago Press, 1992.

Bradbury, Ray. The October Country. 1955. London: Simon \& Schuster, 1998.

Brite, Poppy Z. Lost Souls. 1992. London: Penguin, 1994.

Britten, Rosemary. "Collecting." Antipodean Tales: Stories from the Dark Side. Ed. Stephen Cain. Wellington: IPL Books, 1996. 134-8. 
Brophy, Brigid. "Critical Extracts." Modern Horror Writers. 1965. Ed. Harold Bloom. Writers of English: Lives and Works. New York: Chelsea House Publishers, 1995. 2.

Brottman, Mikita. The Solitary Vice: Against Reading. Berkley: Counterpoint, 2008.

Broughton, William. "Dusted Off: John Hooker's Dunedin Gothic." Landfall 201 (2001): 187-90.

---. "Sargeson, Frank." The Oxford Companion to New Zealand Literature. Eds. Roger Robinson and Nelson Wattie. Melbourne: Oxford University Press, 1998.

Cain, Stephen. Introduction. Antipodean Tales: Stories from the Dark Side. Ed. Stephen Cain. Wellington: IPL Books, 1996. 6-7.

Calder, Alex. "The Closure of Sense: Janet Frame, Language, and the Body." Antic 3 (1987): 93-104.

Campbell, Ramsey. "Avoiding What's Been Done to Death." How to Write Tales of Horror, Fantasy \& Science Fiction. 1987. Ed. J.N. Williamson. London: Robinson, 1990. 96-100.

Casines, Gisela. "Elements of the Gothic." Rev. of The Literature of Terror: A History of Gothic Fictions from 1765 to the Present Day, by David Punter, Science Fiction Studies 9.3 (1982): 331-2.

Castle, Mort. "Reality and the Waking Nightmare: Setting and Character in Horror Fiction." How to Write Tales of Horror, Fantasy \& Science Fiction. 1987. Ed. J.N. Williamson. London: Robinson, 1990. 28-34.

Chabon, Michael. Introduction. "The Editor's Notebook: A Confidential Chat with the Editor." McSweeney's Mammoth Treasury of Thrilling Tales. Ed. Michael Chabon. N.p.: Penguin, 2004. 5-8.

Church of England. "In the Time of Dearth and Famine." The Book of Common Prayer, and Administration of the Sacraments and Other Rites and Ceremonies of the Church of England. Birmingham: J. Thompson, 1791. 52.

Cohen, Emily Jane. "Kitschen Witches: Martha Stewart: Gothic Housewife, Corporate CEO." The Journal of Popular Culture 38.4 (2005): 650-77.

Cologne-Brooks, Gavin. Dark Eyes on America: The Novels of Joyce Carol Oates. Baton Rouge: Louisiana State University Press, 2005.

Copland, R. A. Frank Sargeson. New Zealand Writers and Their Work. Wellington: Oxford University Press, 1976.

"Court Told of Naked Girl Dancing among Coffins." The Times June 12 1974: 5.

Craft, Christopher. "'Kiss Me with Those Red Lips': Gender and Inversion in Bram Stoker's Dracula." Representations 8 (1984): 107-33.

Craig, David. "Gothic Inversions and Displacements: Ruins, Madness and Domesticated Modernism." Gothic NZ: The Darker Side of Kiwi Culture. Eds. Misha Kavka, Jennifer Lawn and Mary Paul. Dunedin: Otago University Press, 2006. 39-50.

---. "Taranaki Gothic and the Political Economy of New Zealand Narrative and Sensibility." New Zealand Sociology 20.2 (2005): 18-40. 
Crawford, Gary William. "Robert Aickman: A Bibliography." Fantasy Commentator 9.2 (1997): 143-8.

---. Robert Aickman: An Introduction. Gothic Chapbooks 7. Baton Rouge: Gothic Press, 2003.

Creed, Barbara. The Monstrous Feminine: Film, Feminism, Psychoanalysis. London: Routledge, 1993.

Creighton, Joanne V. Joyce Carol Oates: Novels of the Middle Years. Twayne's United States Authors Series. New York: Twayne Publishers, 1992.

Creswell Moorcock, Alyson. "Never Go Tramping Alone." Antipodean Tales: Stories from the Dark Side. Ed. Stephen Cain. Wellington: IPL Books, 1996. 63-71.

Croce, Benedetto. Aesthetic as Science of Expression and General Linguistic. Trans. Douglas Ainslie. 2nd ed. London: Macmillan, 1929.

Cronin, Jan. "'Encircling Tubes of Being': New Zealand as Hypothetical Site in Janet Frame's A State of Siege (1966)." Journal of New Zealand Literature 23.2 (2005): 79-91.

Crouch, Stanley. "Aunt Medea." 1987. Notes of a Hanging Judge. New York: Oxford University Press, 1990. 202-9.

Crow, Charles L., ed. American Gothic: An Anthology 1787 - 1916. Malden: Blackwell, 1999.

---. Introduction. American Gothic: An Anthology 1787 - 1916. Ed. Charles L. Crow. Malden: Blackwell, 1999. 1-2.

Curnow, Allen. "Aspects of New Zealand Poetry." 1943. Look Back Harder: Critical Writings 1935-1984. Ed. Peter Simpson. Auckland: Auckland University Press, 1987. 32-41.

---. Introduction. The Penguin Book of New Zealand Verse. Ed. Allen Curnow. Harmondsworth: Penguin, 1960. 17-67.

---. "Introduction to A Book of New Zealand Verse 1923-45." 1945, 1951. Look Back Harder: Critical Writings 1935-1984. Ed. Peter Simpson. Auckland: Auckland University Press, 1987. 42-75.

Daalder, Joost. "Violence in the Stories of Frank Sargeson." Journal of New Zealand Literature 4 (1986): 56-80.

Daly, Brenda. Lavish Self-Divisions: The Novels of Joyce Carol Oates. Jackson: University Press of Mississippi, 1996.

de Man, Paul. Introduction. Toward an Aesthetic of Reception. By Hans Robert Jauss. Trans. Timothy Bahti. Minneapolis: University of Minnesota, 1982. vii-xxv.

Delrez, Marc. "The Eye of the Storm: Vision and Survival in A State of Siege." The Ring of Fire: Essays on Janet Frame. Ed. Jeanne Delbaere. Sydney: Dangaroo Press, 1992. 126-38.

Derrida, Jacques. "The Law of Genre." Critical Inquiry 7.1 (1980): 55-81.

---. Writing and Difference. Trans. Alan Bass. Chicago: University of Chicago Press, 1978. 
Dirda, Michael. "The Wine-Dark Sea." Bound to Please: An Extraordinary OneVolume Literary Education. New York: W.W. Norton \& Company, 2005. 235-7.

Drakakis, John, and Dale Townshend, eds. Gothic Shakespeares. Accents on Shakespeare. Abingdon: Routledge, 2008.

Dubey, Madhu. "The Politics of Genre in Beloved." NOVEL: A Forum on Fiction 32.2 (1999): 187-206.

Dudding, Robin, ed. In Celebration, for Frank Sargeson at 75. Spec. issue of Islands 6.3 (1978): 209-360.

Duff, David. Introduction. Modern Genre Theory. Ed. David Duff. Harlow: Longman, 2000. 1-19.

---, ed. Modern Genre Theory. Harlow: Longman, 2000.

Duggan, Maurice. "Notes on an Abstract Arachnid." Collected Stories. Ed. C.K. Stead: Auckland: Auckland University Press; Auckland: Oxford University Press, 1981. 36-9.

Dylan, Bob. "A Hard Rain's A-Gonna Fall." Bob Dylan: Lyrics 1962-2004. New York: Simon \& Schuster, 2004. 59.

Edmundson, Mark. Nightmare on Main Street: Angels, Sadomasochism and the Culture of the Gothic. Cambridge, MA: Harvard University Press, 1997.

Edwards, Justin D. Gothic Passages: Racial Ambiguity and the American Gothic. Iowa City: University of Iowa Press, 2003.

Edwards, Thomas R. "Gulp!" Rev. of It by Stephen King and Whirlwind by James Clavell. The New York Review of Books 33.20 (1986): 58-60.

Eisinger, Chester E. Fiction of the Forties. Chicago: University of Chicago Press, 1963.

Ellis, Bill. "The Highgate Cemetery Vampire Hunt: The Anglo-American Connection in Satanic Cult Lore." Folklore 104.1/2 (1993): 13-39.

---. Raising the Devil: Satanism, New Religions, and the Media. Lexington: The University Press of Kentucky, 2000.

English, James F. The Economy of Prestige: Prizes, Awards, and the Circulation of Cultural Value. Cambridge, MA: Harvard University Press, 2005.

Evans, P.D. "'Farthest from the Heart': The Autobiographical Parables of Janet Frame." Modern Fiction Studies 27.1 (1981): 31-40.

Evans, Patrick. "Baby Factory." New Zealand Listener 16-22 August 2003: 50-3.

---. Janet Frame. Twayne's World Authors Series. Boston: Twayne Publishers, 1977.

---. "On Originality: No Earth Tones." Writing at the Edge of the Universe. Ed. Mark Williams. Christchurch: Canterbury University Press, 2004. 68-84.

Fischer-Lichte, Erika. Theatre, Sacrifice, Ritual: Exploring Forms of Political Theatre. London: Routledge, 2005.

Fitzgerald, Lauren. "Female Gothic and the Institutionalization of Gothic Studies." Gothic Studies 6.1 (2004): 8-18. 
Forster, E.M. "Other Kingdom." The New Collected Short Stories. London: Sidgwick \& Jackson, 1985. 62-85.

Fox, Janet. "Overview of Horror, SF and Fantasy: A Long-Range Market Study." How to Write Tales of Horror, Fantasy and Science Fiction. 1987. Ed. J.N. Williamson. London: Robinson, 1990. 165-76.

Frame, Janet. "The Lagoon." The Lagoon and Other Stories. Christchurch: The Caxton Press, 1961. 7-11.

---. A State of Siege. 1966. A State of Siege and the Rainbirds. The Janet Frame Collection. Auckland: Vintage, 2006. 23-244.

Frankfurter, David. Evil Incarnate: Rumours of Demonic Conspiracy and Satanic Abuse in History. Princeton: Princeton University Press, 2006.

Franks, Lucinda. "The Emergence of Joyce Carol Oates." 1980. Joyce Carol Oates: Conversations 1970 - 2006. Ed. Greg Johnson. Princeton: Ontario Review Press, 2006. 85-97.

Freud, Sigmund. Beyond the Pleasure Principle. Trans. James Strachey. New York: Liveright, 1961.

Frow, John. Genre. The New Critical Idiom. Oxon: Routledge, 2006.

Frye, Northrop. Anatomy of Criticism: Four Essays. 1957. Princeton: Princeton University Press, 1990.

Gamer, Michael. Romanticism and the Gothic: Genre, Reception and Canon Formation. Cambridge Studies in Romanticism. Cambridge: Cambridge University Press, 2000.

Gardner, John. "More Smog from the Dark Satanic Mills." Rev. of A State of Siege, by Janet Frame, amongst others. The Southern Review ns. 5.1 (1969): 224-44.

Gee, Maurice. Under the Mountain. Wellington: Oxford University Press, 1979.

Gelder, Ken. Reading the Vampire. Popular Fictions Series. London: Routledge, 1994.

Gilbert, Sandra M., and Susan Gubar. The Madwoman in the Attic: The Woman Writer and the Nineteenth-Century Literary Imagination. Yale Nota Bene. 2nd ed. New Haven: Yale University Press, 2000.

Gilman, Charlotte Perkins. "The Yellow Wallpaper." American Gothic Tales. Ed. Joyce Carol Oates. New York: Plume, 1996. 87-102.

Goddu, Teresa. Gothic America: Narrative, History and Nation. New York: Columbia University Press, 1997.

Grant, Charles L. "Stepping into the Shadows." How to Write Tales of Horror, Fantasy \& Science Fiction. 1987. Ed. J.N. Williamson. London: Robinson, 1990. 64-6.

Grattan, C. Harley. "Tawdry Lilies." Rev. of Owls Do Cry, by Janet Frame. New York Times Book Review 31 July 1960: 22.

Haggerty, George E. Gothic Fiction/Gothic Form. University Park: Pennsylvania State University Press, 1989. 
Haining, Peter. Introduction. The Shilling Shockers: Stories of Terror from the Gothic Bluebooks. Peter Haining, ed. London: Victor Gollancz, 1978. 13-19.

Hantke, Steffen. "The Decline of the Literary Horror Market in the 1990s and Dell's Abyss Series." The Journal of Popular Culture 41.1 (2008): 56-70.

Harding, Bruce. "The Nativization of Feeling: Motifs of Bonding to the Past and to the Land in Janet Frame's A State of Siege (1966) and in The Carpathians (1988)." Journal of New Zealand Literature 18/19 (2000/1): 114-38.

---. "The Oil on the Salad or, 'Being Frank About Frank: The Conjunction of Religious and Judicial Legalisms and the "Sodomite Rule" In Frank Sargeson's Life and in The Hangover (1967)'." Journal of New Zealand Literature 16 (1998): 58-71.

Hatcher, Harlan. "The Torches of Violence." The English Journal 23.2 (1934): 91-9.

Hayward, J. W. Frank Sargeson: An Annotated Bibliography: Works and Critical Comment. Wellington: Library School, National Library of New Zealand, 1975.

Hedman, Iwan, and Jan Alexandersson. Four Decades with Dennis Wheatley. DAST Dossier 1. Köping 1973.

Hicks, Granville. "Eudora Welty." College English 14.2 (1952): 69-76.

Hoare, Rose. "Art of Darkness." Sunday Star-Times 12 November 2006: Magazine 16-21.

Hoffman, Daniel. Poe Poe Poe Poe Poe Poe Poe Garden City, NY: Doubleday, 1972.

Hooker, John. Jacob's Season. London: Barrie \& Jenkins, 1971.

Horner, Avril, and Sue Zlosnik. Gothic and the Comic Turn. New York: Palgrave Macmillan, 2005.

Howatch, Susan. The Devil on Lammas Night. 1970. London: Pan, 1974.

Huizinga, J. Homo Ludens: A Study of the Play-Element in Culture. International Library of Sociology. London: Routledge \& Kegan Paul, 1949.

Huyssen, Andreas. After the Great Divide: Modernism, Mass Culture, Postmodernism. Bloomington and Indianapolis: Indiana University Press, 1986.

Idiart, Jeanette, and Jennifer Schulz. "American Gothic Landscapes: The New World to Vietnam." Spectral Readings: Towards a Gothic Geography. 1999. Eds. Glennis Byron and David Punter. Basingstoke: Palgrave Macmillan, 2002. 127-39.

Ihimaera, Witi. "Dustbins." Ihimaera: His Best Stories. Auckland: Reed, 2003. 11625.

Jackson, Mark, and Christopher Braddock. "Incised Skin and Other Spurs." Gothic NZ: The Darker Side of Kiwi Culture. Eds. Misha Kavka, Jennifer Lawn and Mary Paul. Dunedin: Otago University Press, 2006. 90-100.

Jackson, Michael. Minima Ethnographica: Intersubjectivity and the Anthropological Project. Chicago and London: The University of Chicago Press, 1998. 
Jameson, Fredric. The Political Unconscious: Narrative as a Socially Symbolic Act. London: Routledge, 1989.

Jauss, Hans Robert. Toward an Aesthetic of Reception. Trans. Timothy Bahti. Minneapolis: University of Minnesota Press, 1982.

Jenkins, Philip. Decade of Nightmares: The End of the Sixties and the Making of Eighties America. New York: Oxford University Press, 2006.

Jensen, Kai. "Frank at Last." Opening the Book: New Essays on New Zealand Writing. Eds. Mark Williams and Michele Leggott. Auckland: Auckland University Press, 1995. 68-82.

Johnson, Greg. Understanding Joyce Carol Oates. Understanding Contemporary American Literature. Columbia: University of South Carolina Press, 1987.

Johnson, Randal. Introduction. "Pierre Bourdieu on Art, Literature and Culture." The Field of Cultural Production: Essays on Art and Literature. Ed. Randal Johnson. New York: Columbia University Press, 1993. 1-25.

Jones, Lawrence. "Frank Sargeson and the Great New Zealand Novel." Journal of New Zealand Literature 16 (1998): 72-85.

---. "Once Is Not Enough: On Re-Reading Sargeson." Islands 6.3 (1978): 268-72.

Kakutani, Michiko. "Did Paco's Story Deserve Its Award?" New York Times 16 November 1987, late ed.: C15.

Kanfer, Stefan. "King of Horror." Time October 6 1986: 74-78, 80, 83.

Kavka, Misha. "Out of the Kitchen Sink." Gothic NZ: The Darker Side of Kiwi Culture. Eds. Misha Kavka, Jennifer Lawn and Mary Paul. Dunedin: Otago University Press, 2006. 57-65.

Kavka, Misha, Jennifer Lawn, and Mary Paul, eds. Gothic NZ: The Darker Side of Kiwi Culture. Dunedin: Otago University Press, 2006.

Kavka, Misha, and Misery. "Misery: Art and Fashion." Gothic NZ: The Darker Side of Kiwi Culture. Eds. Misha Kavka, Jennifer Lawn and Mary Paul. Dunedin: Otago University Press, 2006. 134-8.

Kember, Sarah. "Metamorphoses." Monstrous Media/Spectral Subjects. International Gothic Association Conference. Lancaster University, 22 July 2009.

Kiely, Robert. The Romantic Novel in England. Cambridge, MA: Harvard University Press, 1972.

Kiernan, Caitlín R. Silk. New York: Roc, 1998.

King, Michael. Frank Sargeson: A Life. Auckland: Viking, 1995.

---. Wrestling with the Angel: A Life of Janet Frame. Auckland: Viking, 2000.

King, Stephen. Danse Macabre. 1981. London: Futura, 1982.

---. It. 1986. London: New English Library, 1987.

---. Notes. Skeleton Crew. 1985. London: Futura, 1986. 606-12.

---. "The Raft." Skeleton Crew. 1985. London: Futura, 1986. 287-318. 
Kisner, James. "Freedom of Originality in Fantastic Fiction - and How to Use It." How to Write Tales of Horror, Fantasy \& Science Fiction. 1987. Ed. J.N. Williamson. London: Robinson, 1990. 51-5.

Knipe, Michael. "Cult Leader Sent His Girl Friends out to Beg." The Times 6 December 1969: 4.

Knox, Elizabeth. Daylight. Wellington: Victoria University Press, 2003.

Kohler, Dayton. "Carson McCullers: Variations on a Theme." The English Journal 40.8 (1951): 415-22.

Kunstler, William M. The Minister and the Choir Singer: The Hall-Mills Murder Case. London: Panther, 1967.

Lakoff, George. Women, Fire, and Dangerous Things: What Categories Reveal About the Mind. Chicago: University of Chicago Press, 1987.

Lamb, Hugh. "Wheatley, Dennis (1897 - 1977)." The Penguin Encyclopaedia of Horror and the Supernatural. Ed. Jack Sullivan. New York: Viking, 1986.

Lawn, Jennifer. Introduction. "Warping the Familiar." Gothic NZ: The Darker Side of Kiwi Culture. Eds. Misha Kavka, Jennifer Lawn and Mary Paul. Dunedin: Otago University Press, 2006. 11-21.

---. "Scarfies, Dunedin Gothic, and the Spirit of Capitalism." Journal of New Zealand Literature 22 (2004): 124-40.

Lawn, Jenny. "Domesticating Settler Gothic in New Zealand Literature." New Literatures Review 38 (2002): 46-62.

Lay, Graeme, and Stephen Stratford, eds. An Affair of the Heart: A Celebration of Frank Sargeson's Centenary. Auckland: Cape Catley, 2003.

Lee, Christopher. Introduction. Christopher Lee's New Chamber of Horrors. Ed. Peter Haining. London: Souvenir Press, 1974. 11-14.

Levin, Harry. The Power of Blackness: Hawthorne, Poe, Melville. 1958. New York: Alfred A. Knopf, 1970.

Levine, Lawrence W. Highbrow/Lowbrow: The Emergence of Cultural Hierarchy in America. Cambridge, MA: Harvard University Press, 1988.

Lincoln, Victoria. A Private Disgrace: Lizzie Borden by Daylight. London: Victor Gollancz, 1968.

Lloyd-Smith, Alan. American Gothic Fiction: An Introduction. Continuum Studies in Literary Genre. New York: Continuum, 2004.

Lochhead, Ian. "Corrugated Iron Gothic." Gothic NZ: The Darker Side of Kiwi Culture. Eds. Misha Kavka, Jennifer Lawn and Mary Paul. Dunedin: Otago University Press, 2006. 80-9.

Longueil, Alfred E. "The Word 'Gothic' in Eighteenth Century Criticism." Modern Language Notes 38.8 (1923): 453-60.

Lovecraft, H.P. "Supernatural Horror in Literature." 1927. The H.P. Lovecraft Omnibus 2: Dagon and Other Macabre Tales. London: Grafton, 1985. 421512. 
MacLean, Nancy. Behind the Mask of Chivalry: The Making of the Second Ku Klux Klan. New York: Oxford University Press, 1994.

Magistrale, Tony. Landscape of Fear: Stephen King's American Gothic. Madison: The Popular Press, 1988.

Magnuson, Ed. "The Curse of Violent Crime." Time March 23 1981: 16-30.

Malterre, Monique. "Myth and Esoterics: A Tentative Interpretation of A State of Siege." The Ring of Fire: Essays on Janet Frame. Ed. Jeanne Delbaere. Sydney: Dangaroo Press, 1992. 120-5.

Manlove, Colin. The Fantasy Literature of England. Basingstoke: Palgrave, 1999.

Mansfield, Katherine. "Silhouettes." Katherine Mansfield: Publications in Australia 1907-09. Ed. Jean E. Stone. Sydney: Wentworth Books, 1977. 32-3.

---. "Study: The Death of a Rose." The Triad 1 July 1908: 35.

---. "The Woman at the Store." The Collected Stories. London: Penguin, 2007. 55062.

Mantell, Laurie. "Turehu." Antipodean Tales: Stories from the Dark Side. Ed. Stephen Cain. Wellington: IPL Books, 1996. 87-91.

Marcus, Greil. Invisible Republic: Bob Dylan's Basement Tapes. New York: Henry Holt and Company, 1997.

Marsh, Ngaio. "Is the Detective Story Dying?" New Zealand Listener 17 October 1947: 8 .

Matthews, Philip. "Local Infections: New Zealand Horror." Landfall 201 (2001): 1837.

McCammon, Robert R. "Innocence and Terror - The Heart of Horror." How to Write Tales of Horror, Fantasy \& Science Fiction. 1987. Ed. J.N. Williamson. London: Robinson, 1990. 67-70.

McDowell, Edwin. "Fatherhood and It Top Sellers of '86." New York Times January 5 1987, late ed.: C18.

---. "Publisher's Gamble: One Book, Two Types of Paperback." New York Times 28 January 1991, late ed.: D6.

McEldowney, Dennis. "By the Lake." Classic New Zealand Short Stories. 1953. Ed. Dan Davin. Auckland: Oxford University Press, 1997. 245-7.

---. Frank Sargeson in His Time. Dunedin: John McIndoe, 1976.

---. "Ways of Reading." Rev. of Frank Sargeson by R.A. Copland. Islands 6.3 (1978): 359-60.

McGrath, Patrick, and Bradford Morrow. Introduction. The New Gothic: A Collection of Contemporary Gothic Fiction. 1991. Eds. Patrick McGrath and Bradford Morrow. London: Picador, 1993. xi-xiv.

---, eds. The New Gothic: A Collection of Contemporary Gothic Fiction. 1991. London: Picador, 1993.

Medway, Gareth J. The Lure of the Sinister: The Unnatural History of Satanism. New York: New York University Press, 2001. 
Mercer, Gina. Janet Frame: Subversive Fictions. Dunedin: University of Otago Press, 1994.

Miller, Carolyn R. "Rhetorical Community: The Cultural Basis of Genre." Genre and the New Rhetoric. Eds. Aviva Freedman and Peter Medway. London: Taylor \& Francis, 1994. 67-78.

Moers, Ellen. Literary Women. 1977. London: The Women's Press, 1980.

Moorcock, Michael. Foreword. Vast Alchemies: The Life and Work of Mervyn Peake. By G. Peter Winnington. London: Peter Owen Publishers, 2000. np.

Morgan, Kenneth O. "The Wilson Years: 1964 - 1970." From Blitz to Blair: A New History of Britain since 1939. Ed. Nick Tiratsoo. London: Weidenfeld and Nicolson, 1997. 132-62.

Morrieson, Ronald Hugh. The Scarecrow: A Novel. Sydney: Angus and Robertson, 1963.

Morrison, Michael A. "After the Danse: Horror at the End of the Century." A Dark Night's Dreaming: Contemporary American Horror Fiction. Eds. Tony Magistrale and Michael A. Morrison. Columbia: University of South Carolina Press, 1996. 9-26.

Morrison, Toni. Beloved. 1987. London: Vintage, 2005.

---. Playing in the Dark: Whiteness and the Literary Imagination. Cambridge, MA: Harvard University Press, 1992.

Morrissey, Michael. Introduction. The Flamingo Anthology of New Zealand Short Stories. Ed. Michael Morrissey. Auckland: Flamingo, 2000. 9-19.

Movers and Shakers: The 100 Most Influential Figures in Modern Business. Ultimate Business Library. Cambridge, MA: Basic Books, 2003.

Murray, Stuart. Never a Soul at Home: New Zealand Literary Nationalism and the 1930s. Wellington: Victoria University Press, 1998.

Neill, Sam. Cinema of Unease: A Personal Journey by Sam Neill. British Film Institute and Top Shelf Productions, 1995.

Nell, Victor. Lost in a Book: The Psychology of Reading for Pleasure. New Haven: Yale University Press, 1988.

Nicks, Oliver. "The House." Antipodean Tales: Stories from the Dark Side. Ed. Stephen Cain. Wellington: IPL Books, 1996. 8-20.

Nietzsche, Friedrich. Beyond Good and Evil: Prelude to a Philosophy of the Future. Trans. Helen Zimmern. Edinburgh: T.N. Foulis, 1909.

Nolan, William F. "Involving Your Reader from the Start." How to Write Tales of Horror, Fantasy \& Science Fiction. 1987. Ed. J.N. Williamson. London: Robinson, 1990. 46-50.

"Novels of the Year." The Times December 28 1961: 11.

Oates, Joyce Carol. "Afterword (1985 Edition)." Celestial Timepiece: A Joyce Carol Oates Homepage: Mysteries of Winterthurn. 18 Jan. $2010<\mathrm{http}: / /$ jco.usfca.edu/works/novels/winterthurn.html $>$. 
---. "Author's Afterword (2007 Edition)." Celestial Timepiece: A Joyce Carol Oates Homepage: Mysteries of Winterthurn. 18 Jan. $2010<$ http://jco.usfca.edu/ works/novels/winterthurn.html>.

---. "Frankenstein's Fallen Angel." Critical Inquiry 10.3 (1984): 543-54.

---. Mysteries of Winterthurn. London: Jonathan Cape, 1984.

---. Review of Yellow Flowers in the Antipodean Room, by Janet Frame. New York Times Book Review 9 February 1969: 5, 46.

Panny, Judith Dell. I Have What I Gave: The Fiction of Janet Frame. Revised ed. Palmerston North: Dunmore Press with Whitireia Publishing, 2002.

Peake, Mervyn. Boy in Darkness. 1956. London: Hodder Children's Books, 1996.

---. Gormenghast. 1950. The Gormenghast Trilogy. London: Vintage, 1999. 369-752.

---. Titus Alone. 1959. The Gormenghast Trilogy. London: Vintage Books, 1999. 751-953.

---. Titus Groan. 1946. The Gormenghast Trilogy. London: Vintage, 1999. 1-367.

Pearson, Bill. "Fretful Sleepers." 1952, revised 1974. Great New Zealand Argument: Ideas About Ourselves. Ed. Russell Brown. Auckland: Activity Press, 2005. 52-96.

Pirie, David. A New Heritage of Horror: The English Gothic Cinema. London: I B Tauris, 2009.

Platzner, Robert L., and Robert D. Hume. "'Gothic Versus Romantic': A Rejoinder." PMLA 86.2 (1971): 266-74.

Poe, Edgar Allan. "The Black Cat." Collected Works of Edgar Allan Poe. Ed. Thomas Ollive Mabbott. Vol. 3. Cambridge, MA and London: The Belknap Press of Harvard University Press, 1978. 847-60.

---. "The Cask of Amontillado." Collected Works of Edgar Allan Poe. Ed. Thomas Ollive Mabbott. Vol. 3. Cambridge, MA and London: The Belknap Press of Harvard University Press, 1978. 1252-66.

---. "The Fall of the House of Usher." Collected Works of Edgar Allan Poe. Ed. Thomas Ollive Mabbott. Vol. 2. Cambridge, MA and London: The Belknap Press of Harvard University Press, 1978. 392-422.

---. "The Imp of the Perverse." Collected Works of Edgar Allan Poe. Ed. Thomas Ollive Mabbott. Vol. 3. Cambridge, MA: The Belknap Press of Harvard University Press, 1978. 1217-27.

Poore, Charles. "The Psychedelic Power of Human Vanity." Rev. of A State of Siege, by Janet Frame. New York Times 21 July 1966: 31.

"Pooter." The Times 19 August 1969: 19.

Porter, Dilwyn. "'Never-Never Land': Britain under the Conservatives 1951 - 1964." From Blitz to Blair: A New History of Britain since 1939. Ed. Nick Tiratsoo. London: Weidenfeld and Nicolson, 1997. 102-31.

Praz, Mario. The Romantic Agony. Trans. Angus Davidson. Oxford: Oxford University Press, 1933. 
Propp, Vladimir. Morphology of the Folktale. Trans. Laurence Scott. 2nd ed. Austin: University of Texas Press, 1968.

Publisher's Note. The Gormenghast Trilogy. London: Vintage Books, 1999. 758-9.

Punter, David. Introduction. "Of Apparitions." Spectral Readings: Towards a Gothic Geography. 1999. Ed. Glennis Byron and David Punter. Basingstoke: Palgrave Macmillan, 2002. 1-8.

---. The Literature of Terror: A History of Gothic Fictions from 1765 to the Present Day. Digital Print on Demand, 2003 ed. Vol. 2. Harlow: Longman, 1996.

---. The Literature of Terror: A History of Gothic Fictions from 1765 to the Present Day. London: Longman, 1980.

Punter, David, and Glennis Byron. The Gothic. Oxford: Blackwell Publishing, 2004.

Purkiss, Diana. The Witch in History: Early Modern and Twentieth-Century Representations. London: Routledge, 1996.

Radcliffe, Ann. The Mysteries of Udolpho: A Romance, Interspersed with Some Pieces of Poetry. 1794. Oxford English Novels. London: Oxford University Press, 1966.

Ratcliffe, Michael. "Two's Company, but One's a Crowd." Rev. of The Green Man, by Kingsley Amis. The Times 11 October 1969: Books v.

"Rejected Resurrection." Rev. of Yellow Flowers in the Antipodean Room, by Janet Frame. Time 21 March 1969: 105.

Rendle, Steve. "Entertaining Trip to the Dark Side." Rev. of Antipodean Tales:

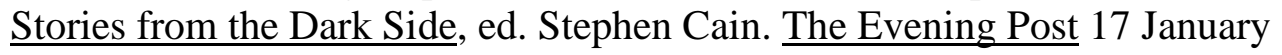
1997, 3rd ed.: Features 5.

Ringe, Donald A. American Gothic: Imagination and Reason in Nineteenth-Century Fiction. Lexington: University Press of Kentucky, 1982.

Sargeson, Frank. "'Gods Live in Woods'." The Stories of Frank Sargeson. Auckland: Penguin, 1982. 228-34.

---. "A Good Boy." The Stories of Frank Sargeson. Auckland: Penguin, 1982. 26-9.

---. "A Great Day." The Stories of Frank Sargeson. Auckland: Penguin, 1982. 68-75.

---. The Hangover. London: MacGibbon and Kee, 1967.

---. "The Hole That Jack Dug." The Stories of Frank Sargeson. Auckland: Penguin, 1982. 243-50.

---. "I've Lost My Pal." The Stories of Frank Sargeson. Auckland: Penguin, 1982. 304.

---. "Letter to a Friend." The Stories of Frank Sargeson. Auckland: Penguin, 1982. 235-42.

---. "Sale Day." The Stories of Frank Sargeson. Auckland: Penguin, 1982. 95-8.

---. "The Undertaker's Story." The Stories of Frank Sargeson. Auckland: Penguin, 1982. 251-61. 
Savoy, Eric. "The Face of the Tenant: A Theory of American Gothic." American Gothic: New Interventions in a National Narrative. Eds. Robert K. Martin and Eric Savoy. Iowa City: University of Iowa Press, 1998. 3-19.

Schafer, William J. Mapping the Godzone: A Primer on New Zealand Literature and Culture. Honolulu: University of Hawai'i Press, 1998.

Schechner, Richard. Performance Theory. Revised and Expanded ed. New York: Routledge, 1988.

Sedgwick, Eve Kosofsky The Coherence of Gothic Conventions. 1980. New York: Methuen, 1986.

Seligman, Adam B, Robert P. Weller, Michael J. Puett and Bennett Simon. Ritual and Its Consequences: An Essay on the Limits of Sincerity. Oxford: Oxford University Press, 2008.

Seligman, Craig. "Toni Morrison." Rev. of Jazz and Playing in the Dark: Whiteness and the Literary Imagination, by Toni Morrison. The Threepenny Review 52 (1993): 7-9.

Sheed, Wilfrid. "When the Spell Works It's Binding." Rev. of The Adaptable Man, by Janet Frame. New York Times Book Review 8 August 1965: 4.

Shieff, Sarah. "Well-Laundered Elves: Purity and Degeneration in The Lord of the Rings." Gothic NZ: The Darker Side of Kiwi Culture. Eds. Misha Kavka, Jennifer Lawn and Mary Paul. Dunedin: Otago University Press, 2006. 111-9.

Sitwell, Edith. "Still Falls the Rain." Collected Poems. London: Macmillan \& Co, 1958. 272-3.

Smithyman, Kendrick. "A Sort of Poet Too." Islands 6.3 (1978): 299-302.

Snitow, Ann. Rev. of Beloved, by Toni Morrison. 1987. Toni Morrison: Critical Perspectives Past and Present. Eds. Henry Louis Gates Jr., and K. A. Appiah. New York: Amistad, 1993. 26-32.

Sontag, Susan. "Against Interpretation." A Susan Sontag Reader. New York: Farrar, Straus and Giroux, 1982.95-104.

---. "Notes on Camp." A Susan Sontag Reader. New York: Farrar, Straus and Giroux, 1982. 105-19.

Stafford, Jane, and Mark Williams. Maoriland: New Zealand Literature 1872-1914. Wellington: Victoria University Press, 2006.

"'Stakes Driven into Corpses in Cemetery'." The Times June 13 1974: 4.

Stanhope, Henry. "How Cult Deals with Its Critics." The Times 26 July 1968: 8.

Strengell, Heidi. Dissecting Stephen King: From the Gothic to Literary Naturalism. Madison: University of Wisconsin Press, 2005.

Summers, Montague. The Gothic Quest: A History of the Gothic Novel. London: Fortune Press, 1938.

Sutton-Smith. The Ambiguity of Play. Cambridge, MA: Harvard University Press, 1997. 
Thompson, G.R. Introduction. "Romanticism and the Gothic Imagination." The Gothic Imagination: Essays in Dark Romanticism. Ed. G.R. Thompson. Pullman: Washington State University Press, 1974. 1-10.

Thompson, Robin. Rev of. "Tim Souster's Titus Groan Music." Tempo ns. 89 (1969): 21-2.

Todorov, Tzvetan. The Fantastic: A Structural Approach to a Literary Genre. Trans. Richard Howard. Cleveland: Press of Case Western Reserve University, 1973.

---. Genres in Discourse. Trans. Catherine Porter. Cambridge: Cambridge University Press, 1990.

Toomey, Philippa. "Sex, Lust Greed." The Times 1 November 1980: Saturday Review 10.

Turcotte, Gerry. "Australian Gothic." The Handbook to Gothic Literature. Ed. Marie Mulvey-Roberts. New York: New York University Press, 1998. 10-19.

Varma, Devendra P. The Gothic Flame: Being a History of the Gothic Novel in England: Its Origins, Efflorescence, Disintegration and Residuary Influence. London: Barker, 1957.

Veeder, William. "The Nurture of the Gothic; or, How Can a Text Be Both Popular and Subversive?" Spectral Readings: Towards a Gothic Geography. Eds. Glennis Byron and David Punter. Basingstoke: Palgrave Macmillan, 1999. 5470.

Walpole, Horace. The Castle of Otranto: A Gothic Story. 1764. London: Oxford University Press, 1964.

Warner, Marina. Phantasmagoria: Spirit Visions, Metaphors, and Media into the Twenty-First Century. Oxford: Oxford University Press, 2006.

Warwick, Alexandra. "Feeling Gothicky?" Gothic Studies 9.1 (2007): 5-15.

Watney, John. Mervyn Peake. London: Michael Joseph, 1976.

Wattie, Nelson. "Marsh, Ngaio." The Oxford Companion to New Zealand Literature. Eds. Roger Robinson and Nelson Wattie. Melbourne: Oxford University Press, 1998. 358-60.

Wedde, Ian. Afterword. "How Gothic Is It?" Gothic NZ: The Darker Side of Kiwi Culture. Eds. Misha Kavka, Jennifer Lawn and Mary Paul. Dunedin: Otago University Press, 2006. 149-59.

Wevers, Lydia. "The Politics of Culture." Writing at the Edge of the Universe: Essays from the 'Creative Writing in New Zealand' Conference, University of Canterbury, August 2003. Ed. Mark Williams. Christchurch: Canterbury University Press, 2004. 109-22.

---. "The Short Story." The Oxford History of New Zealand Literature in English. Ed. Terry Sturm. 2nd ed. Auckland: Oxford University Press, 1998. 245-320.

Wheatley, Dennis. The Devil Rides Out. 1934. London: Mandarin, 1996.

Wiegand, William. "Toby, Pat and Zoe." Rev. of The Edge of the Alphabet, by Janet Frame. New York Times Book Review 23 September 1962: 46. 
Williams, Anne. Art of Darkness: A Poetics of Gothic. Chicago: University of Chicago Press, 1995.

Williams, Mark. Leaving the Highway: Six Contemporary New Zealand Novelists. Auckland: University of Auckland Press, 1990.

---. "Literary Scholarship, Criticism and Theory." The Oxford History of New Zealand Literature in English. Ed. Terry Sturm. 2nd ed. Auckland: Oxford University Press, 1998. 695-736.

Williamson, J.N. Foreword. "'Certain of What We Do Not See'." How to Write Tales of Horror, Fantasy \& Science Fiction._1987. Ed. J.N. Williamson. London: Robinson, 1990. 1-6.

---. "Plotting as Your Power Source." How to Write Tales of Horror, Fantasy \& Science Fiction. 1987. Ed. J.N. Williamson. London: Robinson, 1990. $20-7$.

Wilson, Philip. "Apprentice." Islands 6.3 (1978): 252-4.

Winnington, G. Peter. Vast Alchemies: The Life and Work of Mervyn Peake. London: Peter Owen Publishers, 2000.

Winter, Douglas E. "Darkness Absolute: The Standards of Excellence in Horror Fiction." How to Write Tales of Horror, Fantasy \& Science Fiction. 1987. Ed. J.N. Williamson. London: Robinson, 1990. 156-64.

Wolcott, James. "Stop Me Before I Write Again: Six Hundred More Pages by Joyce Carol Oates." Rev. of A Bloodsmoor Romance, by Joyce Carol Oates. Harper's September 1982: 67-9.

Young, John. "Toni Morrison, Oprah Winfrey, and Postmodern Popular Audiences." African American Review 35.2 (2001): 181-204.

Young, Stark. "Golden Apples." The English Journal 26.9 (1937): 689-97. 